


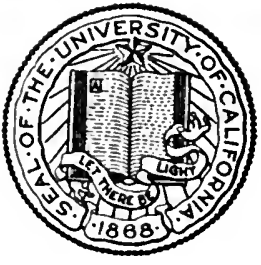

\title{
THE LIBRARY OF
}

THE UNIVERSITY OF CALIFORNIA RIVERSIDE

\author{
GIFT OF
}

Dr. Gordon Watkins 


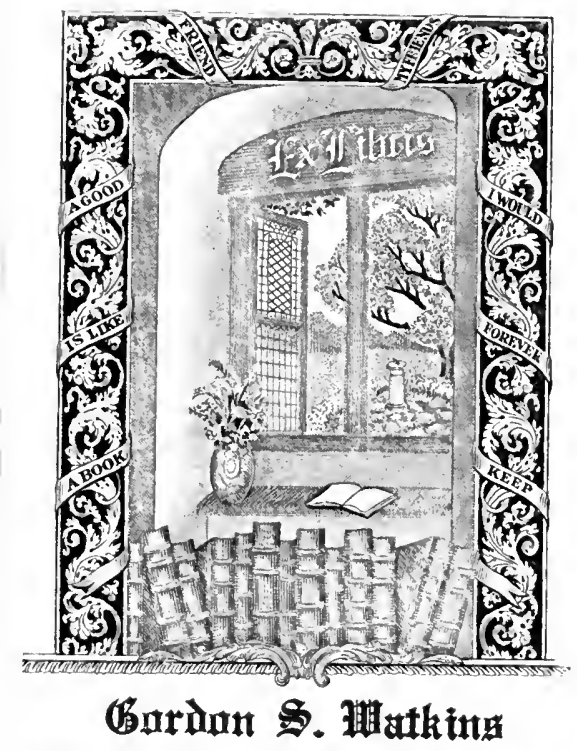




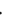




\section{CONSUMERS' \\ CO-OPERATIVE SOCIETIES}


TRANSLATED FROM THE FRENCH BY THE STAFF OF THE CO-OPERATIVE REFERENCE LIBRARY, DUBLIN. WITH AN INTRODUCTION AND SUPPLEMENTARY CHAPTER BY JAMES PETER WARBASSE. EDITED IN THE UNITED STATES BY CEDRIC IONG 


\title{
CONSUMERS' \\ CO-OPERATIVE SOCIETIES
}

\author{
B Y CHARLES GIDE
}

Professor of Political Economy in the Faculty of Laws. University of Paris

NF,W YORK

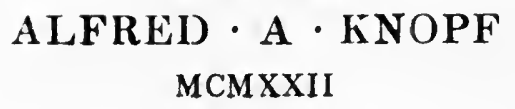


COPYRIGHT, 1922, BY

ALFRED A. KNOPF, INo.

Published, October, 1928

Set up and printed by the Vail-Ballou Ca., Binghamton, N. Y. Paper furnished by $W$. F. Etherington a Co., Nevo York, N. Y. Bound by the H. Wolf Estate, New York, N. Y. 


\section{EDITOR'S PREFACE}

The excellent translation of Professor Gide's "Les Sociétés Coopératives de consommation" which follows is the result of the labors of the staff of the Co-operative Reference Library, Dublin, Ireland. The present editor, in preparing the book for an American public, has, by permission of the fellow-co-operators in Dublin, eliminated such of the English footnotes as were of interest principally to British readers or has incorporated them in his own. He has also moved up into the text many of Professor Gide's notes added by him at the time of the translation into English. Therefore at present there are only the two kinds of footnotes: those of the original author and those of the American editor.

Without the painstaking work of the translators and those who assisted them, this American edition would probably not have been undertaken at this time. Without Professor Gide's help in reading through the proofs and making several valuable suggestions, the book would not have the contemporary value it now possesses. Finally, Dr. Warbasse, in contributing a preface and a chapter on "Co-operation in the United States," has made this book, always indispensible to the student of European Co-operation, an essential to those who are studying the Co-operative Movement in the United States. The present editor is honoured in being able to append a few additional American notes and to prepare this edition for the publisher.

Cedric Long 


\section{Digitized by the Internet Archive in 2007 with funding from Microsoft Corporation}


C O N T E N T S

INTRODUCTION ix

I. Co-operation in the United States, By JaMES P. WARBasse

II. The Orject of a Consumers' Co-operative SocIETY

III. The Co-operative Program: Criticism bY Economists

IV. The History of Distributive Co-operation 31

V. Statistics and Geographical Distribution of the Co-operative Movement

VI. Various Systems of Sale

VII. The Division of Profits 78

VIII. MenBERS 100

$\begin{array}{ll}\text { IX. Capital } & 107\end{array}$

X. Various Types of Consumers' Societies 119

XI. Co-operative Federations 153

XII. The Conflict between Co-operative Societies and Traders 174

XIII. Causes of Success or Failure of ConSUMERS' SOCIETIES

XIV. The Relations between Co-operative Societies and the State

XV. Production by Consumers' Societres 219

XVI. The Employés and Workmen in Co-operaTIVE Socretres

XVII. Co-operation and Socialism INDEX 


\section{INTRODUC'TION}

Two antagonistic economic forces today are striving for supremacy. The conflict between them causes the general social disorganization now obvious. A stabilized society will come to pass only when one or the other of these becomes dominant. The great war was but a minor and subsidiary flare-up in one of the contending camps. Shall the life and industries of the world be conducted for purposes of profit or for purposes of service?-this is the Great Conflict. The war was a melange of hidden motives, uncertainties, hypocrisies and subterfuges; the Great Conflict is clear-cut and definite. On the one side are the most powerful forces in society from the material standpoint. They get their strength from the belief, of the many, in the competitive profit-system. They are supported by the vast interests which subsist upon income from property. They are maintained by the human hunger for privilege and power and the natural desire to have the good things of life without performing service. They are associated with the ownership of the major part of the property of the world. They control the great governments, with their coercive might of arms, police, and jurisdiction over the lives of the people.

On the other side are forces which are as yet weak and but meagrely organized but which are steadily growing. They are impelled by the determined conviction in the minds of people that it is possible to organize the economic affairs of the world upon the basis of production and distribution for service. A hunger is growing among the toiling masses for the control of the aff airs of their lives to this end. Substantiating these tendencies are the facts that the 
workers are organizing more and more effectively as producers in the field of production and as consuners in the field of consumption. The demonstrations of these possibilities are capturing the imagination of the people and creating the vision of larger things. On the first side, and contributing to the strength of the second side, is the present breaking down of the profit-system. There are some who look forward with fear to a collapse of the economic structure of modern society and to a coming revolution. Fears of such a future event are groundless-such a catastrophe need not be anticipated as a possibility of the future-it is already coming to pass. Whether we realize it or not, we are living in the midst of a cataclysm. The old order is breaking to pieces. The life of an individual is a momentary flash in the history of society ; the events through which we are living are burning and quick.

As the profit-motive in industry fails to serve the people as a social instrument, two organizations of society stand ready to assume its functions. One is the political State; the other is the voluntary, non-political organization of the people in the Co-operative Movement. When the present disorder has subsided, the future conflict will be between these two principles. One is the compulsory political idea; the other is the idea of free and voluntary association. Each is making progress. Each moves in the direction of production and distribution for service. Harmonization of these two elements is possible and to be hoped for as an event of the future.

In the reorganization of society now imminent there is a question of paramount importance to be answered: Can the people conduct their own business effectively or must they etcrnally look to private profit-making interests or to the impersonal State to do it for them? This question is answered by the co-operative societies in which the people are giving the world a demonstration of their capacity to 
do things for themselves. They begin with the distribution of the necessities of life, such as food, clothing and shelter, and thus gain better access to the things they need. But what is more important, they learn by experience the technique of carrying on distributive business in the interest of the consumers. Next comes federation of distributive societies, and then wholesaling. This gives experience in the management of big business. Then follows production for use-production in their own factories and workshops for their own non-speculative use. When the consumers have reached back to the ownership of the productive plants, the land and the raw material, the demonstration is complete that the people can conduct their own business from start to finish for service and not for private profit. When this end is reached, the victory is won; a revolution has slowly but definitely taken place.

There is another question: How can the people obtain control of industry and administer it effectively in their own interest? Yoting does not provide the training. There is a prevalent fiction that all that is needed is for the majority of people to vote at an election to instruct the government to take over profit-making industries and use them for the service of the people. But these industries have never been used for that purpose, nor have the people who are administering them and working in them had experience in service for social purposes. The industries and the people have been adjusted to the profit motive. The change is too difficult to be accomplished by an edict. Russia has discovered this.

There is a serious obstacle to the success of the sudden industrial revolutionary method in a certain fact that has received little attention from leaders of labour and less from economists. It is the fact that the organization of society solely upon a producers' basis cannot solve the economic problem. The theory that the workers should capture the 


\section{xii CONSUMERS' CO-OPERATIVE SOCIETIES}

industries by a revolution and that around the industrial function should revolve all of the reforms of the social life, has been responsible for many of the vagaries that have led the people astray. The "Christian socialist" movement, "syndicalism" and "guild socialism" have all been based upon the hypothesis that labour is the great function and that it is at the point of production that mankind needs to begin organization and control. For this reason we find these organizations striving to get for the workers the best rewards possible. This is good as far as it goes, but it never has and it never can solve the workers' problem. It has not the power to change the motive of industry. This method has striven to give the worker "the full value of the wealth he produced." "Full reward for labour" has been the aim. That motive has meant working for wages-producing for wages-and producing with that motive has meant not production for use but production for profit. Labour, like the capitalist, has sought to get as much for itself as possible, and that means as much from the consumers-from all the people-as possible. This psychology is not compatible with production for use. In the trade union, as well as in the merchants' and manufacturers' association, the chief problem is how to get more from the consumer. And no group will solve the economic problem with this motive.

Other exclusively producing enterprises such as the "selfgoverning workshop," "producers' co-operative," and "cooperative communistic colonies," working for wages, producing for profit, laying emphasis on labour as the exalted function, all suffer one and the same fate: they either fail or they become capitalistic-sooner or later. Let workers, in any form of organization, centralized at the point of production, succeed from the financial standpoint, and their organization becomes capitalistic and profit-making. Idealism in that field is compatible with poverty; but not with business success. Success means failure. The industrial coun- 
tries are written over with a hundred years of historic corroboration of this fact. The few successful producers' cooperative enterprises in Great Britain, the larger numbers in Germany, and the still more in Italy and France do not contradict the general truth of this statement. Only this modification need be made: those that are not on the way to fail or to become capitalistic are on the way to be taken over by the consumers' co-operative societies.

That work is the great function is an idea that has been promoted by slave owners, manufacturers, capitalists, schoolmasters, and parents who had no alternative. It is not natural to work. Society has been confused by artificial standards. People work only as a secondary reason. They work in order that they may consume. It is not for the winning of wages; it is for the things that wages will buy that men work. But so much emphasis has been laid upon labour and wages that money has come to be the object both of worker and capitalist. The fact is, that, not in work but in consuming things is to be found the great joys. Food, clothing, housing, music, art, literature, entertainment, love, the pleasure of companionship-these are the things that come into the body through its senses and give it joy. It is not standing at a whirling machine that gives the satisfactions in life; but in consuming the things that can be gotten with the wages obtained, perhaps, in work at the machine.

The one person who merits supreme consideration is the consumer; he is everybody. The alternative to political revolution and to profit-making industrial control is production controlled by the organized consumers and conducted in their interest. This means production for use; and it is the only form of production that has that motive.

If the world is to be saved by substituting for the profit system the system of doing things for purposes of service then it must be saved through the organized Consumers' Movement, The consumers are no class. They are all. 
They are the people standing together, not in drudgery, not by the whirring wheel, but in the enjoyment of things-uniting to help one another secure better access to the things that make life-lielping one another to life in greater abundance.

When the Co-operative method becomes prevalent, then should the worker get the value of what he produces; then should the access to the good things of life be secured by the performance of useful service. Through the Co-operative Movement the prevalent economic competitive system may be supplanted-not by chaos, suffering and revolution, but by an ordered, evolutionary method which employs the humane qualities of friendship and mutual aid, instead of rivalry and antagonism.

My friend, Professor Charles Gide, is the foremost spokesman of this Movement in France. His teaching has clarified its philosophy and illumined its social significance. It is an augury of moment that an economist of his profound scholarship should be drawn to Co-operation as the agency above all others which he believes has the power to reorganize socicty. This book represents a study in the field of fundamental social reorganization, which should prove of great help in promoting an enlightened interest and understanding. It is, indeed, a pleasure to contribute the preface and a privilege to pay homage to its distinguished author.

J. P. W. 


\section{CONSUMERS' \\ CO-OPERATIVE SOCIETIES}



The spirit of co-operation is discovered early in the history of the United States. Although pioneers in a new country are prone to develop individualism and seek their fortunes alone, sooner or later they learn that positive advantages are to be had by union of their forces. Mutual aid is called upon to protect them from the elements and from unfriendly people. As much as the individual may enjoy pushing out alone into the wilderness, he experiences a greater sense of security when he unites with his fellow-men for their mutual benefit. The union of people in the political state is an expression of this sense. In the economic ficld, expressions of co-operation are found in the cooperative and communistic colonies which settled on the land in the latter part of the Eighteenth Century and the early part of the Nineteenth. The oldest of these is the Society of Shakers which was established at New Lebanon, New York State, in $\mathbf{1 7 8 7 .}$

From that time down to the present there have always been colonies in which the members attempted to carry on their industrial and social life in the spirit of co-operation. They have been occupied in farming and other forms of productive work, owning property, selling their produce, and buying in common. They have come and gone. Some have succeeded commercially as businesses, but none have succeeded as social enterprises because their principles 
were of the profit-making type rather than the social. The certain fate of these organizations is either to fail, or, if they succeed from the financial standpoint, to become capitalistic, profit-making enterprises. So long as they are struggling for success their idealism remains; but as soon as they win what they are seeking, their idealism perishes. Their success is their destruction. This is not only the case with so-called "co-operative colonies" but all collective enterprises of producers whose purpose is to make profits by selling to the consuming public.

Then came the Rochdale Era, following the definite formulation of a co-operative philosophy and the working out of a specific plan for putting it in operation. This was the beginning of the Consumers' Co-operative Movement. Its first appearance in the United States was in 1845 when the Workingmen's Protective Union opened its first store in Boston. Since that time the working people have made continuous attempts to establish co-operative societies. In 1853 the International Industrial Assembly of America, with a membership of 200,000 , promoted co-operative enterprises. The National Labor Union did the same in 1866. These were followed by the Patrons of Husbandry, the Granges, the Sovereigns of Industry, and the Knights of Labor. By $187 \%$ these latter organizations had several hundred stores throughout the eastern states. They developed also many productive industries which they called co-operative. The New England Protective Union at one time had 400 distributive stores extending throughout the Atlantic States.

The enterprises established by these old organizations were all deficient from the co-operative standpoint. Most were lacking in the fundamental qualities of Co-operation. The others that could be regarded as co-operative were so deficient in co-operative education that their members rarely understood the nature and possibilities of their enterprise. The great majority failed. 
Another form of early co-operation in the United States was that of the building associations, or "building and loan associations," which extends over a long period. The first organization of this sort was the Oxford Provident Building Association founded near Philadelphia in 1831. From that time to the present there has been an extensive development of these organizations in the United States. They have provided for savings, and for loans for the building of homes. These, like many similar organizations, remained always on the border line but never became fully cooperative.

Co-operative banking and credit associations date back also to the early part of the last century. These early struggling societies were practically all destroyed by the Civil War. Then there crept in from Canada, by way of Massachusetts, banking inspiration brought by Alphonse Desjardins. Later several states enacted co-operative banking laws, and the movement slowly began to spread.

Co-operative distributive societies also have continued to develop with slow but steady improvement since that first store in Boston over seventy-five years ago. There was a period in the early part of the present century when the Socialists became interested in Co-operation and were responsible for organizing many socicties. These suffered from an excess of idealism and a deficiency of practical executive talent. They disappeared. While Co-operation was making its remarkable progress in Europe, it progressed very slowly in this country. Greater difficulty in creating interest has always existed in the United States and the proportion of failures has been larger than in Europe.

The reasons for this slow progress are natural and obvious. The chief reason resides in the fact that until 1916 there was no central source of information and guidance such as existed in each European country; the people started societies that were not co-operative; and they attempted to 
run them without standardized information or guidance. Besides this there were the economic reasons. A new country with limitless opportunities breeds the spirit of individualism. Profit-making business and the eager quest for the dollar dominated the public mind. Each individual hoped to win and to go ahead of his neighbour in the competitive struggle. In no country has the urge of individual profit-making become so strong and the opportunity so great as in the United States. This condition engendered a state of mind in which Co-operation did not thrive.

The newness of the country gave rise to fluctuations of population. 'The people have been restless. They have not remained to live in the neighbourhood where they were born. New neighbours are not good co-operators. The presence of frontiers to the westward, toward which a fluid population could always keep moving, has been an obstacle to the stability necessary for co-operative organization.

The examples of great wealth and the possibilities of "getting on" have always encouraged hope even among the poorest. The idea that any man can grow rich by his own individual actions has deterred people from uniting in a project which is based upon an acknowledgment of the need of mutual aid, and in which the early rewards are so meagre while the efforts are so great.

The mixture of many races and nationalities, with the differences of customs and languages, has militated also against the union of people in co-operative societies.

The strenuous competition among private tradesmen and the allurements of advertising have won the people to a habit of shopping and bargain hunting until these have become a prevalent form of American diversion and recreation. While competition has kept prices down and has made it possible to find reasonable prices, it has prompted the tradesmen to offer every conceivable inducement and enticement for the sake of trade. 
Then too this is the land of the great god "Business." The laws as well as the public psychology are all adjusted to the profit-making system. The influential elements in each community are the "boards of trade," "merchants associations" and "chambers of commerce." These organizations are composed of the prominent citizens. They dominate the schools, the press, and the public thought, as well as the industries. They are organized and operate for the purpose of making profits from the unorganized consumers. And these bodies, found in every community, are naturally opposed to the Co-operative Movement. Every device conceivable that can be used by a powerful organization to destroy a weaker one is resorted to by these elements to suppress co-operative associations, for the latter are capable of demonstrating that the people can carry on business for themselves, in their own interest.

A most serious hindrance to co-operative progress has been the multitude of spurious "co-operative" societies. They vary from the wildest and most fanciful schemes of well-meaning persons to the most unscrupulous fraud. These enterprises take millions of dollars from working people, who are left hostile to true Co-operation. During the past three years these undertakings have been especially flagrant. They have capitalized the growing interest in Co-operation and sold the people a poor imitation. Some of the promoters of these ventures have been sent to prison; most of them are at large, organizing and reorganizing their failing schemes. These organizations follow the chainstore methods. This centralized plan of administration invariably fails. It succeeds in profit business, but in Cooperation it fails for lack of democracy, local interest and efficiency, when downright fraud is not the cause of the failure. The practical reason why even the well-intended among these things have failed has been because of a central bureaucracy which has been ignorant of both co-operative 
theory and practice. During the period from 1919 to 1923 twelve of these centralized undertakings have failed from the Atlantic to the Pacific. They have had presented to them every evidence that their schemes could not succeed, and still they went on collecting money from working people which could have no other fate than to be lost. A characteristic of these organizations has been that they all attacked The Co-operative League, the national educational organization whose function is to give advice on co-operative problems. Among the most conspicuous examples have been the "National Co-operative Association," the "Cooperative Socicty of America," and the "Pacific Co-operative League." Over $\$ 15,000,000$ has been lost in three years in these ventures by deluded people who thought that they were promoting Co-operation. But still greater than this is the loss of the morale which the movement suffers. This is the dark side. It should be kept in mind because the desire for quick results, the contempt for patient education, and the esteem in which the profit motive is held in the United States will continue to operate as causes of disaster unless the people are forewarned.

The brighter aspects are to be seen in every field. For fifty years there has poured into the United States a stream of immigrants from countries having well established Cooperative Movements. These people have brought with them not only the knowledge of what their native societies were doing but they brought a co-operative spirit. There have survived from the early period many societies scattered over the country. A few of these date back nearly forty, and some nearly fifty years. The immigrant people have promoted Co-operation among these old socicties until today co-operative stores are to be found in almost every part of the country. Since 1916 expansion has taken place due partly to the stabilization and enlargement of industry during the war, partly to the conspicuousness of profit- 
eering and the very obvious evils of the profit-making economic system, and partly to the work of The Co-operative League in promoting the knowledge of the fundamentals of Co-operation.

The Movement has developed all over the country. The farmers have done the most of any one class for Co-operation in the United States. This is partly due to the fact that until 1921 the farmers were the largest class. Unlike Great Britain, Germany, and the other industrial countries with a large co-operative development, it has not been the industrial workers but the farmers who have taken the lead. Much help has come from the agricultural population who emigrated from Denmark, Germany, Norway, Sweden and Finland. But old American stock has also played a part in this development. The United States is no longer an agricultural country but an industrial country, now that more than half of its population lives in the cities. The strength of the Co-operative Movement was formerly in the rural districts and largely among the native born; but in the last few years the strongest and largest societies have developed in the industrial centres. This industrial or town movement is predominately foreign born in its leadership.

Many farmers' national organizations have promoted Co-operation. Most important service has been rendered by 'The Farmers' Educational and Co-operative Union. This organization started in Texas in 1902, and has now extended into thirty states. Its primary business is teaching the farmers how to organize as producers to get the best price for their product. This is a trade union or business function. But it performs also the scrvice of teaching these same farmers how to conduct distributive stores. There comes about a very natural sequence. The farmers learn how to work together in their selling organization; they then use it to purchase for themselves agricultural supplies; having taken this step they have their 
first experience as co-operative consumers; then they extend the lines of their co-operative buying to household and personal needs; discovering the value of this method they organize a store, and thus they have engrafted a consumers' distributive machinery upon their agricultural producers' enterprise. Thus have grown up many of the farmers' co-operative societies. Usually the consumers' society, as soon as it is ready for a store, is organized and capitalized as a separate undertaking.

The farmers are found entering into many fields of Cooperation besides the distributive store. They have been particularly successful with insurance. There are in the United States about 2000 co-operative fire insurance companies among the farmers. They carry insurance exceeding $\$ 5,250,000,000$ on property valued at nearly $\$ 7,000$,000,000 . This insurance is carried at one half the rate charged by the profit-making companies. Hail insurance is also provided.

In many towns the farmers have a co-opcrative store, creamery and grain elevator. Banking has not been entered into largely. There are some farmers' societies with good buildings in the town, some of which are used for community centre purposes. A laundry connected with the creamery is one of the many farmers' enterprises. Some societies own flour mills. In some small towns in the middle west and northern states the co-operative societies do most of the business. Co-operative telephone companies developed among the farmers of the middle western states thirty-five ycars ago. The telephone monopoly has not destroyed them.

Without reference to occupation of the members we may take a general view of the distributive societies in this country. In the New England states there are about seventy-five distributive societies. A few are the old societies. Most, however, were established in the present 
century. The largest single group is that of about thirty organizations in Eastern Massachusetts; most of these are composed of Finns. The societies at Fitchburg and Maynard are particularly strong. They have stores, restaurants, bakeries, and creameries. In the middle Eastern states are 250 societies located chiefly in Pennsylvania among the coal and iron workers and in and near New York City. The Central States have about 100 societies in Illinois. A lesser number are in Ohio and Indiana. Most of the Illinois organizations are connected with the Central States Co-operative Society which has a wholesale house at East St. Louis, Illinois. 'This has a turnover of $\$ 3,000,000$ a year. The members of the constituent societies are mostly coal miners. In Illinois are some of the best examples of successful Co-operation. Societies of this type average about 250 members, have a turnover of $\$ 160,000$ a year and pay savings-returns of from 4 to 7 per cent. quarterly. The Illinois societies do a business of about $\$ 10,000,000$ a year.

In the northern part of Michigan, Wisconsin and Minnesota are over 100 societies composed largely of Scandinavians. The Co-operative Central Exchange at Superior, Wisconsin, is a wholesale composed of fifty of these societies. Besides supplying general merchandise it manufactures the peculiar bread and biscuit products required by the Finnish societies, all over the country. This organization conducts a school for the training of co-operative executives. Its educational work is most effective.

Most societies in the United States have under 1000 members. Two societies in Northern Michigan, established in 1890, have more than that number. One of the successful younger societies of that district, organized in 1912, has over 400 members, owns its own three story stone building, operates a bakery, two meat markets, and four branch grocery stores, and has a turnover of $\$ 300,000$ a year. 
Among the northern and western agricultural states are scattered societies. Kansas has 275 consumers' societies. Nebraska has about the same. The Farmers' Exchange at Omaha is the central wholesale. These societies distribute groceries, dry-goods, clothing, hardware, machinery and all kinds of goods.

The Southern States have a few scattered societies, but the Movement in the South is backward. In 1878 the National Grange organized the Texas Co-operative Association. Ten years later the association had 155 stores and 6000 members and was doing a business of $\$ 2,000,000$ a year. About this time the Grange organized a co-operative educational association which established a co-operative school in Louisiana for the members' children, with a capital of $\$ 8,000$. The school was truly co-operative and paid savings-returns to patrons. Societies conducting stores were established throughout the South between 1877 and 1890 by the Grange and the Knights of Labour. Most of these have disappeared. The negroes have recently become interested in Co-operation and are establishing distributive societies.

The Pacific States have a newer movement. The general prosperity of the people and newness of the communities seems to have militated against interest in Co-operation. A scattering of societies existed in California the latter part of the Nineteenth Century. These suffered from the inexperience and apathy of the members. Some were finally closed because they had developed a good big surplus and the members' fingers itched to get possession of it, so the societies were disbanded on account of their success. Lack of education and standardization seemed to be the chief trouble. In the early part of the present Century there were close to a hundred societies in California. By 1910 there were only about a score left. Then came a growth of societies connected up with an unsound method of centralized control, 
which led to vicious practices and failure in 1922. In the meantime a true co-operative movement sprang up in the Pacific States in the form of independent societies. With these as a nucleus a sound development is making progress.

Much publicity has been given to the fruit-growers, prune and grape producing organizations of the Pacific Coast. They have been called "co-operative." Under no circumstances should they be classified with Rochdale cooperative societies. The former are profit-making businesses. Many of them have succeded. Their success may be measured by the following fact which is also a test of their character: before the prune producers' co-operative was organized, the people were able to buy prunes for nine cents a pound; but so successful has this organization become that the consumers are now paying twenty-nine cents a pound for the same prunes.

Many racial groups are taking an active part in the promotion of Co-operation in the United States. A group that stands out most eminently for its idealism, efficiency and loyalty is that of the Finns. Their societies in New England and in the Northern States are most successful. Other racial groups which are making their contributions to the structure of Co-operation in this country are the English, Scotch, Germans, Scandinavians, Jews, Italians, Bohemians, Poles, Slovaks, and people from the Balkan countries. Many societies are composed largely or exclusively of these several groups.

The retail store is the most common co-operative enterprise in the United States. There are about 3000 of these. Co-operative bakeries have been promoted especially by the Jews, although many non-Jewish societies have bakeries. A baking society in New York, two in New Jersey, and one in Michigan have more than 1000 members each.

A form of Co-operation which is unique is the co-operative school. There are three of these in New York which are 
organized, financed, owned and controlled by the consumers - the students. These schools prepare students for college and regents' examinations and give business and general cultural courses. The faculty is selected and employed by the society of students the same as any other consumers' society employs its experts, and is entirely under the direction of the students, who also make up the curriculum. Compared with the profit-making schools in this field, these schools are superior; the teachers are paid better and the costs to the students are less.

Co-operative housing has recently been attempted on a small but satisfactory scale. This is a field in which Cooperation is urgently needed and in which it could serve the people most efficiently in this country. Aside from the many spurious enterprises, there are some genuine cooperative housing socicties. These societies have built the houses and own them; the members take leases for as long a period as they please, practically having possession in perpetuity. By cutting out the real-estate speculator, the exploiting contractor and the landlord, these co-operators enjoy advantages which should compel the recognition of this method of housing as most economical and most practical. The American working-man non-co-operator pays one fourth of his wages for house-rent and the German working-man co-operator pays one-eighth to one-fifteenth of his wages for a better home than that in which the American working-man lives. When this is finally understood the people of this country should eventually see where their best interest lies. In no country are the people so exploited and so at the mercy of the land speculator and the landlord as in the United States. The people are rapidly losing their homes. Co-operation offers them the chance to recover them.

Co-operative milk distribution has recently been developed to a successful point. Some societies in Massachusetts have 
contracts with the farmers to produce milk for them. They collect the milk, treat it in their own creameries, bottle and deliver it. In Minneapolis is a co-operative creamery-a consumers' distributive society-organized in 1921. They built their own creamery-building and distribute milk to their 2000 members. As a result of the establishing of this society, profit-making dealers in the city of Minneapolis have been compelled to reduce the price of milk three cents a quart. The mere presence of this society is saving the people of Minneapolis $\$ 1,500,000$ a year. The cleanliness and quality of the milk have also improved.

Co-operative banking is making headway. Massachusetts and New York have about 150 societies. Ten other states have co-operative banking laws. Some of the large labour unions are now energetically promoting this cause.

Other expressions of Co-operation in the United States are motion picture shows, restaurants, boarding houses, hotels, recreational clubs and purchasing agencies.

As yet the United States has no national co-operative wholesale society such as is to be found in about twenty other countries. The nearest approach to such a commercial organization are the district wholesales already mentioned. These are owned and controlled by groups of local societies which they serve. Nor have these wholesales entered into production except in the one instance referred to above.

There is a borderland of Co-operation in which are many organizations lacking only some one or more of the Rochdale principles to make them fully co-operative. In this class are over 550 fraternal life insurance societies with over $9,000,000$ members and $\$ 10,000,000,000$ of insurance in force. They pay about $\$ 100,000,000$ annually in benefits. These non-profit organizations are co-operative to a high degree.

Co-operation is developing with the endorsement of the Labour Movement. The American Federation of Labour and 


\section{4}

CONSUMERS' CO-OPERATIVE SOCIETIES

other labour organizations are giving aid to its promotion. Most of the societies are now started among trade unionists or among organized farmers. The employment of union labour is insisted upon as a rule in the better class of societics. Co-operative societies succeed, provided that they have efficient administration and observe the simple rules of genuine Co-operation. Although a majority in this country have neglected education and strict observance of co-operative rules they succed in spite of their mistakes. The failures among them are much fewer in proportion to the amount of business than among profit-making concerns.

A peculiarity of the movement in this country is the fact that it is endorsed by every class of organization laying any claim to social usefulness. Every type of labour organization, with the rare exception of some of the branches of the Industrial Workers of the World, is friendly to Co-operation. The Socialist Party, the Communist Party, the Republican Party and the Democratic Party in national, state and local conventions have passed resolutions endorsing Cooperation. The Catholic Church and the Protestant Church organizations have passed such resolutions. The Interchurch World Movement, the Federation of Churches, and many other large religious organizations are among these endorsers. It is a noteworthy fact that in the United States Catholic leaders are giving sympathetic help to Co-operation, and arlvising Catholics to join the regular co-operative societies. Every effort is being made to prevent the split in the movement which exists in Europe where the Catholics are outside of and hostile to the regular co-operative socicties.

The American Movement is demonstrating that it is capable of harmonizing all classes. It is the common ground upon which all who hope for the brotherhood of man may unite. That there is such a force, with which the discontented as well as the contented, the radical as well as the 
conservative are willing to unite, is a hopeful sign for the security of society.

No country ever had a strong and substantial growth of Co-operation until it had a national co-operative organization. This has been the deficiency in this country. To meet this need, The Co-operative League was organized in 1915 and started work in 1916 with headquarters in New York City. It is an organization which collects all possible information concerning Co-operation in the United States; makes surveys of failures and successes; publishes information; gives advice; standardizes methods; creates definite policies of action; prepares bylaws for societies; drafts bills to be introduced in legislative bodies; promotes favourable legislation; sends out advisors to societies; provides lectures; prepares study courses; conducts a school; publishes books, pamphlets and periodicals; and in every way possible promotes practical Co-operation. The League is a federation of co-operative societies, governed by its constituent members. Already the best and strongest of the societies are its members. Through The League the United States Movement is connected with the International Co-operative Alliance which is composed of the similar national unions or leagues of twenty-six countries.

The First National Co-operative Congress held under the auspices of The Co-operative League was at Springfield, Illinois, in 1918; the Second Congress was at Cincinnati, Ohio, in 1920; and the Third Congress will be at Chicago in 1922.

The great need in the United States is for the fundamental educational work which The League is doing. The day of propaganda has passed. What is needed is standarized information and practical guidance based upon the sound principles of Co-operation. This movement has been so effectively standardized, that success and failure can be predicted and controlled. It is not more societies that are 


\section{CONSUMERS' CO-OPERATIVE SOCIETIES}

needed but more knowledge among the people of the practical principles and technic necessary to success.

In no country will Co-operation have a more difficult path. Profit-making business is in absolute and dominant control. But the fundamental economic changes must comeare coming. The salvation of the people must be by one of two methods. They must either learn their lesson by suffering, perhaps, by bloody revolution, with all of the reaction, delays and distress which these have in store; or they must learn their lesson by education-a slower, surer, evolutionary way. Which of these the people of this country will employ on their way to emancipation remains to be seen. It is by the path of education and evolution that the Co-operative Movement would lead.

\section{Biblognapiry on Co-operation in the United States}

"Communistie Soeieties in the United States," 1895, Charles Nordhoff. "History of Co-operation in the United States," 1888, Johns Hopkins University Studies.

"Co-operative Savings and I,oan Associations," 1889, Seymour Dexter. "Co-operation in New England," 1913, James Ford.

"Co-operative Credit for the United States," 1917, Henry W. Wolff. "Co-operation," Vols. I to VI, published by 'The Co-operative League.

"Transactions" First (1918) and Second (1920) National Congresses, The Co-operative Icague. 
THE O B JECT OF A CONSUMER S' C O-O PER A TIVE SO CIETY

In a broad sense a consumers' co-operative socicty exists every time that a number of persons feeling the same need join together collectively to satisfy it better than they could do by individual means.* It would follow, therefore, from this definition that every consumers' society has for its object production, since to supply any need it is necessary to produce; and, indeed, that is the aim of consumers' co-operation, but, as a matter of fact, it only achieves this at an advanced point in its evolution. In its beginnings a consumer's' co-operative society is satisfied with buying the requirements necessary for its members; it is a shopkeeper long before it is a manufacturer. Generally a beginming is made with the most important of all needs, the supply of foodstuffs, or in one of the particular branches of this general need, such as the supply of bread, wine, groceries. Thus, Monsignor von Ketteler, Archbishop of Mainz, said that the question of co-operation is summed up in the simple question of food supply; but that does not belittle it.

If the consumers' society had no other aim but to enable

*Author's Note. It is almost impossible to give a precise definition of a co-operative society, on account of the great variety of objects aimed at. In any case, in our opinion, it is impossible to include a consumers' and a producers' society under the same definition, because, in spite of the apparent identity of their aims, these aims are really antagonistic, as we shall see later. However, in certain Italian books, by Wollenborg, Pantaleoni, Valenti, Mariani, \&c., we find subtle and ingenious analyses which attempt to embrace all forms of co-operation under one synthetic formula. 


\section{CONSUMERS' CO-OPERATIVE SOCIETIES}

the working classes and the poor to feed themselves better, that would be no small thing. To convince oneself that that is not a negligible end it is sufficient to consider: (1) That a considerable proportion of the working-class population (which Messrs. Charles Booth and Rowntree estimate at 27 to 30 per cent. in English towns) do not get the minimum wage necessary to maintain life; they do not receive the minimum wage necessary to buy the number of food units required for the maintenance of the human body. That the means of purchasing at the disposal of the workman-already very small-are further wasted by his inability to use them with economy. He buys in small quantities-a halfpenny worth of sugar or of coffee-from small hucksters, whose goods are sold at third or fourth hand, deteriorated in quality and raised in price, each middleman having taken his profit on the way. When he is forced to buy on credit he submits, either through ignorance or through apathy, to all the frauds which the fierce struggle for life forces on hucksters as poor as himself. He has even to pay an insurance to the shopkecper, in the form of increascd prices, against the insolvency of those of his comrades who do not pay. These conditions are so unfavourable that, as has been pointed out with savage irony, "there are not many rich men who could afford themselves the luxury of buying under the same conditions as the poor."

Consumers' co-operation, above all when it is supported by strong purchasing federations, swceps away all this misery. If a society aims at cheapness only it can sell goods well below current commercial prices, and even if, as is generally the case, it sells at the ordinary trade price, the consumers buy goods of better quality-more nourishing food and more lasting clothes-and also gain an increase in quantity resulting from just weights used for bread, for meat, for everything. It becomes an institute of social hygiene of the first order, and certainly has been one of the 
factors in the remarkable decline of tuberculosis in England.

In spite of what Monsignor von Ketteler says, consumers' co-operation is not confined to the supply of food stuffs, but is able to extend to all the needs of human life, such as clothing, furnishing, and, above all, housing (the last is so important a category that the societies for the supply of houses are generally treated separately under the name of building societies). In the United States there are hundreds of towns where consumers' co-operative association has for its object the creation and exploitation of a telephone system. In New York, Brussels, Berlin, and Milan the owners of motor cars have formed co-operative societies to supply themselves with petrol, tires, and other accessories, in purchasing which the consumer has been scandalously exploited. And not only to the supply of material needs, but also to intellectual and moral ones, including all that contributes to well-being, all that adds to the comfort and charm of life. One can well imagine-in fact, there already exist-co-operative clubs, co-operative theatres, cooperative newspapers, and, above all, co-operative churches, that is to say, institutions formed and maintained by those who wish to gain by them, to instruct, amuse, and edify themselves in common. ${ }^{1}$

What makes the success of consumers' co-operation is the very fact that its ends are most varied. Whatever is wanted of it can be obtained. It lends itself with marvellous ease to any social aim, even the most diverse-sometimes, it must be avowed, the most antagonistic-so that we must choose between them. As we shall see, one can seek in consumers' co-operation either cheapness or an increase of income, savings for the individual or the constitution of an

1 In greater New York there are three co-operative schools in which the students (adolescent and early adult) employ their own teachers and administer the affairs of the schools. In the United States there are also two or three moving picture theatres owned and controlled by the patrons. 
inalienable fund for social benefits; but one cannot seck all these results at the same time. Thus it is that one can see conservatives or revolutionists, bourgeois or workmen, collectivists or anarchists, Protestants or Catholies, preach co-operation in turn, although with very different objects.

It is also noticeable that besides the direct aim co-operative societies set before themselves they can serve indirectly all aims by the direction in which their funds are used. Thus we shall see the socialist co-operative societies in Belgium and in the North of France using their funds for political propaganda. Those Jews who are known as Zionists have formed a consumers' society in London, of which 30 per cent. of the profits are devoted to the development of the Zionist movement, that is to say, to laying the foundations of the new kingdom of Jerusalem; this is surely an unforescen object of co-operative effort-other such will arise. $^{2}$

French economists who have concerned themselves with consumer's' co-operation considered at first that its only end was saving (see the last chapter of this book); but today that idea is quite out of date.

In what does co-operation differ from mutuality? Has not that also for its end the providing for the satisfaction of certain wants, as in the form of sickness benefit, old age pensions, burial societies, \&c.? Doubtless both are sisters, in that both spring from the idea of mutual aid and solidarity, but their features are very different. Mutual aid societies fight against risks which threaten human life-

2 One large co-operative lodging house in New York is devoting its surplus to a fund which is divided between Russian Faminc Relief and the campaign for the liberation of Political Prisoners in the United States.

The Central States Co-operative Wholesale Society of East St. Louis, Illinois, put all its faeilities at the disposal of the United Mine Workers who raised money for the striking miners in Kansas. The Wholesale shipped more than 40 carloads ( $\$ 200,000$ worth) of food to these strikers during the last threc months of 1921. 
sickness, old age, and death; they are of a philanthropic nature, and were formerly called "brotherhoods." Cooperative socicties have for their object the providing for the needs of every-day life by new economic means; they are businesses in the true sense of that word in political economy. This difference of aims is so real that French law has had to make different codes for the one and the other. Nutual aid societics have one special form of legislation, co-operative societies another; for the one, capital is required, for the other, periodical subscriptions are enough. When it is a question of societies for the insurance of goods--such as fire or live stock insurance-or even credit societics, i. e., societies for the borrowing of capital, the words "mutual aid" and "co-operative" society are used almost indifferently. 
THE CO-OPERATIVE PROG RA M :

CRITICISM BY ECONOMISTS

The immediate aim of co-operative societies is to satisfy the needs of their members better and more economically than is done by existing institutions; for example, if the need be bread, to furnish it of better quality, juster weight, and more cheaply than the bakers can supply it. Is their claim to do this well founded? It seems at first sight very daring, for is it probable that simple consumers, who by their very definition are not specialists, could be capable of making bread or supplying any other service cheaper and better than the bakers or members of the trade? Is not that a contradiction of the great law of the division of labour and of exchange? Is it not a return to a state of savagery, to the life of a Robinson Crusoe, or to a feudal family who had to provide for all their needs by their own exertions?

That is the objection on which the economists lay stress; yet the experience of nearly all countries for the last half century, vouched for by countless successes, has proved indisputably that the claim made by co-operators is well founded. No doubt the co-operative business is heavily handicapped, first of all by the lack of technical capacity, and even more by the lack of personal management, of "the master's eye." The manager lacks the stimulus of individual profit, whether he be a salaried official or even a philanthropist.

But, on the other hand, a co-operative society, having 
to provide for the needs of its members only, can do so with certainty, particularly if its members are conscientious and loyal in purchasing from the store. It has not to run the risks of bad speculation and of bad stock which must be sold at a loss. Besides, the co-operative business, as it does not need luxurious premises-since it does not appeal to the public-and as it runs no risks of bad debts-since it does not usually sell on credit-is freed from the two heaviest expenses which weigh on ordinary commercial enterprises. Finally, a co-operative society can often obtain the services of honest, capable, and devoted managers at a far lower price than capitalist enterprises have to pay. One of the former directors of the English Co-operative Wholesale Society, Mir. J. T. Mitchell, in replying to an American economist, Graham Brooks, who asked him how he was satisfied with so small a salary, said, "I enjoy the esteem of my colleagues; I have great power; I have great faith in the co-operative ideal. These things satisfy me." $\mathrm{By}$ these means co-operation brings into the economic order and places at the service of industry a new and very powerful factor-disinterested energy. ${ }^{1}$

These factors are enough to balance all the disadvantages resulting from the inexperience of its managers, and, in the struggle against the traders, have given the advantage to

1 Many of the American societies enjoy all these advantages. But by far the larger number are less fortunate. Though luxurious premises are not needed, too many inexperienced boards of directors luxuriate in excessive overhead expenditures. Very many managers have wrecked their societies by laying in huge stocks of goods at peak prices which had to be sold later at a great loss. There are far and away too many managers in the American societies who have been taken out of positions in private stores because of their experience in buying and selling, who know and care nothing about co-operation, and who are in the position to demand the same wages to which they have been accustomed. Finally, there are many hundreds of the societies in the United States which do sell on credit, in order to competc successfully with the private merchants. This becomes almost imperative during times of unemployment among the members. 
co-operation. In fact, contrary to general belief, one does not find more failures among co-operative societies than among ordinary traders, and where statistics are procurable they show that co-operative failures are fewer. The co-operative review of Hamburg (Konsumgenossenschafts Rundschau), in its number of 18th January, 1908, commented on the official statistics of failures in the German Empire for 1905-1906. In capitalist enterprises with share capital there were 24 failures, out of 4,952 companies, a proportion of 4.85 per 1,000 , and there were 27 failures out of 25,714 co-operative societies, which is a proportion of 1.43 per 1,000 only. True, the majority of these cooperative failures were credit, and not consumers', societies, which would make the average more favourable; but, on the other hand, it should be noted that the statistical returns of the capitalist concerns refer to large businesses only, and not to small traders, and that the latter are the ones whose failures are most frequent. ${ }^{2}$

As for saying that co-operative organization abolishes the division of labour and brings us back to the primitive times when each man was constrained to produce for himself everything essential for his needs, it is true in so far as one can say that a consumers' co-operative society is an enlarged family which-as was formerly the case, and is the case today on certain farms-makes its own bread and jam, and which also spins, weaves, washes, \&c. Yet it is not the consumer himself who does all that, but specialized workers, preferably members of the societies. If the division of labour is abolished from the economic point of view it remains in full force from the technical point of view, and that is enough to ensure progress.

One may say that co-operative association confines itself

2 Many guesses have been made as to the proportion of co-operative failures to capitalistic failures in this country, but no accurate figures are available. 
to transforming that co-operation which already exists in a latent state in all human society into conscious, organized co-operation. It is one of the favorite themes of economists to point out how the play of individual efforts produces involuntarily a general harmony; unfortunately, facts prove that this harmony is often but a frightful discord. The co-operative society's rôle is to make each man play in tune; it is the conductor of the orchestra.

The function which we have just indicated as characteristic of consumers' co-operation-the most economical satisfaction of all the needs of life-suffices for the greater number of societies in the world today. Moreover, by itself it would be enough to make co-operation a factor of the first importance in economic evolution and to gain for it an ever-increasing number of supporters, not only among those workers whose wages merely suffice to maintain life, but also among the middle classes, officials, clerks, or persons of small private means who are crushed between the increase in their needs-owing to the spread of luxury-and the decrease in their incomes, by reason of the increase in taxes and the depreciation of Government stocks.

If the greater number of co-operators only seek from cooperation the means of living better, there are a small number in every country where the co-operative movement has made headway, who seek something more from it-the attainment of greater justice in economic relations. ${ }^{3}$ It is not for nothing that the Rochdale weavers called themselves the "Equitable Pioneers." They did not content themselves with seeking from co-operation an increase in comfort for the poorer classes, "the chicken in the pot" promised by

3 Almost all of the societies in the United States have leaders of this kind, even though the membership generally is money-minded. Any society which is entirely lacking in such idealism faces almost certain failure; it cannot compete with the highly organized chain stores with their inferior quality of goods at reduced prices, their low overhead expcnse, and their tremendous buying power. 
King Henry IV. They sought to find in it an instrument of economic transformation, not only in the sphere of exchange, but also in that of production and the division of wealth. A co-operative organization for the distribution of wealth which had as its foundation a competitive system of production would form a highly unstable, perhaps uninhabitable edifice. They also sought to find in co-operation an equitable division of wealth, enabling the consumers to keep for themselves all the gains of the enterprise. Their system is the inauguration of a new system of the division of wealth; it would mean that capital would have no more profits. Co-operation, therefore, means nothing less than an economic system destined to supersede capitalism by mutual aid, by one more like the earlier "domestic" system (see Chapter xr).

Co-operative association brings with it the hope of moral progress; but in abolishing the pursuit of profit as the only real motive of economic activity-substituting for it the sole aim of satisfying needs-whilst abolishing advertisement, lying, cheating, and inducements to extravagance, cooperation will succeed in establishing in business a reign of truth and justice; in short, it will establish the "fair price." If we sought to define the object of co-operation in two words these last would be enough.

No doubt economists will reply that to seek such an end is unscientific, because neither co-operative association, nor even the State, has the power to fix a "fair price," or any price. Only the economic factors known as "the law of supply and demand" are able to do this.

Still, the fixing of prices is more and more the end sought by commerce and industry; they seek to safeguard prices from the fluctuations caused by competition. It is for that reason that the fixed price has become the rule in all big markets, and that the manufacturers themselves tend more and more to compel shopkeepers to sell goods bearing 
their trade-marks at a fixed price, by forbidding them to sell below the price marked. This system, which has spread widely in the United States-under the name of "price maintenance"-has hardly yet appeared in France, except amongst chemists - for patent medicines-and among publishers.

But the fixed price has nothing in common with the co-operators" "fair price"; instead of eliminating profit it increases it, making it a direct element in the price of goods. If this system becomes general the consumer will be absolutely handed over to the discretion of the producer. That is why it must be answered by the co-operative system, which also tends towards fixed prices, but prices fixed by the consumer, and forbidding sale above the price marked.

We shall see, later, by what developments of co-operative association it is hoped to produce these great results, but we can say at once that it is by asking co-operators to give up, either wholly or in part, the individual economies which they gain from co-operation, or, at least, to deposit their annual savings in co-operative hands and to use the collective capital thus constituted to erect factories, buy land, and build houses, the profits from which will naturally go into co-operative funds, so that co-operation, like the snowball, will, little by little, swallow up the profits which up to now have gone exclusively to those who possess capital. It is not a question of expropriating the capital already in the hands of the capitalists, but one of forming new capital for the working classes.

Socialists object that it is ridiculous to suppose that the wage-earning classes will ever be able to raise from their wages - which are already insufficient to support them-new capital. But why, since they admit (not without exaggeration, but that is of little importance) that all existing capital is but the product of labour, formed by the labour of past ages, why not admit that new work exerting the same effort 
can produce as much capital and keep it for itself? And if the workers gave up supporting the old capital and turned themselves solely to using the new capital which would be their own, then the old capital would gradually become useless, would become dry and empty as the cocoon after the butterfly has taken flight. ${ }^{4}$

We recognize that this ideal is far from being realized, and that co-operation has not done much towards reforming commercial customs. 'The pursuit of bonuses-“divihunting," as the English call it-is scarcely less keen than profit-hunting, and there are even societies into which the worst bourgeois vices, such as illicit commissions, have introduced themselves. But that happens only when the co-operative society, instead of reforming current conditions, has let itself become saturated by them. In spite of such cases of unfaithfulness to the co-operative ideal co-operation none the less keeps its striking characteristic of being at the same time highly idealistic and very practical. It is at once Martha and Mary, Don Quixote and Sancho. It follows the blue bird, but instead of seeking it in the Fortunate Islands, shuts it up in a shop. It sets before itself the reformation of the world; it begins by sweeping the pavement before its own door and setting its own house in order. It follows the stars; but looks before it leaps. Professor Marshall, the eminent economist, said in his speech as President of the Co-operative Congress, at Ipswich, in 1889: "What distinguishes co-operation from every other movement is that it is at once a strong and calm and wise business, and a strong and fervent and proselytizing faith."

One often hears the somewhat academic question discussed: Is co-operation an end, or only a means? For the

4 It has been estimated that all the capital in circulation in the United States passes thrice annually through the hands of the wage earners. 
great majority of those who rally round the co-operative movement "bourgeois" co-operation, as it is often called, is only a means, a means of living better without spending more or, as we shall see later on, of saving without denying oneself. For those collectivists or anarchists who support co-operation it is also only a means, a means of preparing the advent of the collectivist or anarchist régime by training and arming the people for a class war; by supplying them with the necessary fortresses, munitions, and technical training, in order that on the morrow of the great revolution the people will find themselves capable of maintaining the services of production and distribution. For the differences between the so-called "middle-class" co-operation and that called "socialist," see the last chapter of this book.

But for those who love co-operation for itself, the true co-operators, whom critics ironically call "mystics," cooperation is an end in itself. Not that they are prepared to rest content with the results already gained, but because they believe that co-operation is a living organism, and that the results achieved already contain the germs of all the possibilities to be wished for in the future, as the seed contains the fruit in a latent state. To drop metaphor, they believe that each co-operative society which obeys the laws that it has made for itself already constitutes a little world organized in conformity with justice and social benefit, and that it is sufficient to let it develop spontaneously, either by growth or imitation, to realize in the more or less distant future the best of all possible worlds.

In reply to those economists who laugh at these pretensions to social regeneration, one may say that they only amount to an attempt at realizing one of the principles of a classical school of economists which Bastiat, a few hours before drawing his last breath, expressed in these words: "Political economy must be treated from the point of view 
of the consumer." The co-operative program is to place the consumer in a position of economic domination. M. Pantaleoni puts this question: What new element can co-operation bring among those which influence supply and demand? We answer: None, we admit; but it would enable the law of supply and demand to work under conditions which open competition has never been able to realize (see page 80),

It is true that public opinion, especially that of protectionists and socialists, considers the producer far more useful economically, and morally nobler, than the consumer, because he almost always produces for others, while the consumer always consumes for himself and for his own benefit, and in consequence that it would be wrong to sacrifice the former to the latter.

But it is merely playing with words to pretend that the producer, in the existing economic organization, lives for others. $^{5}$ If the baker makes bread he does not seek to feed his customers, but to make profits; and if he does feed them it is because this is his only way of gaining these profits. It is only in co-operative association that production is organized solely with the view of satisfying needs. In fine, it is not a question of sacrificing either the producer or the consumer, but of putting each in his proper place in society. But it is evident that the producer only exists for the benefit of the consumer, the baker for those who are hungry; it is not the other way round. It is this truth, too often falsified in the actual economic order of things, that the consumers' society seeks to re-establish.

$5 \mathrm{Or}$ that the employe in the bakery works for others; he works for the wages which will enable him to get enjoyment out of life. There are co-operative bakeries in the United States where the workers receive, in many instances, a straight wage of more than \$ro per week and often get as high as $\$ 100$ by working overtime. Attempts on the part of devoted co-operators to induce the bakers' union to reduce these demands have been unavailing; the leaders of the unions and even the majority of the members of the co-operative society insist that these bakers shall receive from co-operators the same wage they are able to procure from private bakers. 
TH E H ISTORT OF DISTRIBUTIVE CO-OPE RATION

\section{(1) In, Great Britain}

The date and the birthplace of distributive co-operation is well known to every one-the 21st of December, 1844, at Rochdale, near Manchester-and the name of the society which was, and is still, the parent of the innumerable family of societies engendered by its spirit and after its model, is "The Equitable Pioneers of Rochdale." This is the date on which the first store-a mean little shop-was opened in Toad Lane, but the date of the registration of the society is 24th October, 1844. The house where the first shop was opened is still in existence, and it is hardly credible that it does not belong to the society, which, although having become prosperous, does not own the house where it was born. At the Co-operative Congress, held in 1914, a vote of credit $(£ 2,000)$ was passed for this purpose, but the war has so far put off this act of reparation. These pioneers were weavers, some of whom were disciples of Owen, that is to say, socialists, others were Chartists, but all of them had the vigorous confidence of the English mind in self-help, or rather in mutual aid. It took them one whole year of painful effort to collect the little capital which they deemed indispensable, and after many desertions twenty-eight of them remained loyal, with a capital of $£ 28$. This is the starting point of a movement which to-day, after only seventy-six 
years, has penetrated every country, and unites more than twenty millions of families.

The title of "Father of Co-operation" is often given to Robert Owen, who was still living at the time of the Rochdale Pioneers, several of whom were his disciples. It is true that this socialist (who was at one time a big employer) has very admirably defined co-operation by this formula: "You must become your own merchants and your own manufacturers .. to be able to supply yourselves with goods of the best quality and at the lowest price." It is also true that he popularized the word "co-operation." But Owen, being pre-occupied in realizing complete co-operation in his "towns of harmony" under the form of communism-more particularly that of community of land-was always somewhat disdainful of co-operative stores; any effort towards the partial realization of co-operation in the guise of a shop he regarded as being more likely to discredit his system than to herald its approach.

However, it would be an error to suppose that Rochdale was the first society. From the end of the 18th century several societies could be mentioned. The existence of a consumers' co-operative society has been discovered in a village in Oxfordshire, at Mongewell, where it had been started on the initiative of the Bishop of Durham, in 1794. Mr. Maxwell, in his History of Co-operation in Scotland, claims priority for a little society, which was existing in 1769 in the village of Fenwick, in Ayrshire. In 1820 a league was formed "for the propagation of co-operation," and up to 1840, under the influence of Owen and his disciples, the propagandist movement for co-operation was very active. There were leagues, journals, congresses; small tracts were distributed by the million; nothing was left undone. There were several congresses of co-operative societies during this period (1830-1833), including onc on October 4th, 1831, at Birmingham, at which the establishment of a wholesale 
society was decided upon, and the duty of education was impressed on co-operative societies. Another was held in London in the following year. Hundreds of societies were founded as a result of this campaign; in 1832 there were 3000 ; even a wholesale society was started about this time in Liverpool. Some of the societies existing at present, notably that of Sheerness, which dates from 1816, are older than the Rochdale one.

But all these consumers' societies (distributive societies, as they are called in England) had one fault which arrested their development and ended by causing their extinctionthey were philanthropic movements of patronage, almost of charity. They were created out of a feeling of pity, because of a desire to relieve the miseries of the working classes, caused by the terribly low wages in the first half of the 19th century, when machinery was taking the place of manual labour, and aggravated by the high price of bread, which the protective duties on grain continued to increase for the benefit of the landlords-duties which the noble campaign of Cobden and of John Bright, who was a native of Rochdale, was soon to abolish. Founded with the capital of philanthropists who only played the part of honorary members in the society and did not use the so-called co-operative store for themselves; not looking for anything but cheapness; not seeking any profits - which, if made, were distributed among the shareholders and not among the customers, or sometimes buried in an inalienable reserve fund which would only serve for visionary schemes for the benefit of future generations-they did not attract new members and were therefore unable to develop, but revolved perpetually in a vicious circle. Somewhat later another method of employing the profits was tried, namely, that of an equal distribution among all the members; but this was not more happy in its results. As a matter of fact, this system of equality put the enthusiastic members who conscientiously made all their purchases in 
the common store on the same footing as the indifferent ones who never came there at all.

However, the really fruitful idea of these Rochdale pioneers of Charles Howarth,* was that of distributing the profits, not according to the net receipts or number of shares or equally among all the members, but in proportion to the trade of each member, this trade being checked in the simplest manner by means of dockets given of equal value to the money received at the cash-desk. It appears that other societies had tried this system before; it had even been tried in a benefit society in 1827; but this time the results were incalculable. It was the fillip which set in full motion the hitherto inactive machinery. $\dagger$ Presently we shall see the reason why this was so.

It is evident that through the adoption of this new system of distribution the co-operative movement assumed a more individual character than heretofore. It was no longer communistic or equalizing-as Owen had desired-because every one was recompensed according to services rendered. But it preserved one aspect of communism by asking members to leave their individual dividends as deposits in the common fund, which would thereby be increased and employed collectively, at first for the development of the society and then for propaganda and social education. It must be admitted that of these two tendencies-both somewhat antagonistic to the co-operative movement-it has been the latter, the individualist tendency, which has been most de-

* Author's Note. The centenary of Charles Howarth's birth (he was born in 1814, and died in 1868) was celebrated in England a few years ago. One of his biographers calls him the "Archimedes of Co-operation." He was a working weaver, quite uneducated, but familiar with the doctrines of Owen.

+ $\Lambda$ uthor's Note. "The History of the Rochdale Pioneers" was written and published in 1858 by George Jacob Holyoake. This marvellous book, re-edited and translated into every language, has contributed not a little to the development of co-operation in many parts of the world. 
veloped up to the present. But efforts are being made to revive the earlier tendency.

It seems then only right that history has awarded the title of "Fathers of Co-operation" to the twenty-eight weavers, who formed the Society of the Equitable Pioneers of Rochdale. They have doubly merited this title:

First, by the broad prophetic manner in which they drew up the program of co-operation for their time, and for all time. The following is their famous manifesto. At least, this is as it was reproduced in the Pioneers' Almanack for 1854. It seems, however, according to Miss B. Potter (Mrs. Sydney Webb) that this program had already been formulated by co-operators at Brighton in 1827. In any case, if the Pioneers have not the merit of being the first to formulate it, they have had the greater honour of realizing it in the greatest possible measure.

"The objects and plans of this Socicty are to form arrangements for the pecuniary benefit and the improvement of the social and domestic condition of its members, by raising a sufficient amount of capital, in shares of one pound each, to bring into operation the following plans and arrangements :-

"The building, purchasing, or erecting of a number of" houses in which those members, desiring to assist each other in improving their domestic and social condition, may reside.

"To commence the manufacture of such articles as the Society may determine upon, for the employment of such members as may be without employment, or who may be suffering in consequence of repeated reductions in their wages.

"As a further benefit and security to the members of this Society, the Society shall purchase or rent an estate or estates of land, which shall be cultivated by the members who may be out of employment, or whose labour may be badly remunerated. 


\section{6}

CONSUMERS' CO-OPERATIVE SOCIETIES

"That, as soon as practicable, this Society shall proceed to arrange the powers of production, distribution, education and government; or, in other words, to cstablish a selfsupporting home colony of united interests, or assist other societies in establishing such colonies.

"That, for the promotion of sobriety, a Temperance Hotel be opened in one of the Society's houses as soon as convenient."

Secondly, because they were not content merely to formulate the program and the ideal of co-operation and to demonstrate from afar the goal which it was slowly nearing, but found practical means of realizing it. And when it is remembered that these rules were from the first so definitely established by these few working flannel weavers that the experience of three-quarters of a century has been unable to add much to them, and that thousands of societies since formed have bound themselves to copy them almost literally, we must recognize this as one of the most remarkable phenomena in economic history. Yet it passed quite unnoticed by economists of that time, even by Mill. The co-operative movement has not issued from the brain of a wise man or a reformer, but from the very life of the people themselves.

We now give the most striking events in the history of co-operation in England after the period of the Pioneers. In 1852 and 1862 laws called the Industrial and Provident Societies Acts were passed. The first Act in particular, which was the Magna Charta of co-operation, gave legal rights to the societies, hitherto without guarantees or corporate existence, and whose property could therefore be appropriated by the first member who wished to take possession of it. This law was largely due to the efforts of a small group of religious men, known as the Christian Socialists-of whom one of the most celebrated was the clergyman and writer, Charles Kingsley,-with the help of the great economist, John Stuart Mill, although these men sought 
their ideal in productive rather than distributive co-operation, and more among the French socialists than among the Rochdale Pioneers. For the English Christian Socialists, as for the French socialists, the evil to be fought was the wage-system, while for Owen and his school it was the system of profit. Nevertheless, thanks to them, co-operation in all its forms gained not only legislative sanction, but also the support of public opinion. Undoubtedly, wageearning and profit-making are, as it were, the two sides of the same coin. Both imply the subordination of labour to capital; but whereas producers' association seemed to be the only remedy whereby to abolish the wage system, it is consumers' co-operation which leads more directly to abolition of profit (see Chapter xvi).

In 1864 we see the establishment in Manchester of the wholesale federation called the Co-operative Wholesale Society, or, more familiarly, the C. W. S., which has exercised a powerful influence on the English co-operative movement, an influence which is increasing from day to day (see Chapter xr). This step was mainly due to the initiative of Abraham Greenwood, one of the survivors of the Rochdale Pioneers. The C. W. S. represents the economic and practical side of co-operation. This institution, which is now strikingly successful, only succeeded in keeping alive after repeated set-backs. Wholesale agencies had already been opened, following on the first Congress at Birmingham, in 1831, and later, in 1850, on the initiative of the Christian Socialists. But the ground had not been sufficiently prepared, and they collapsed. Besides, up till the Act of 1862, such federations were legally non-existent.

In 1869 the Co-operative Union was formed. The affairs of this body are administered by a central executive, known as the United Board, which acts on behalf of all English co-operators; its authority, however, is purely moral. The Union holds annual congresses, which are like sessions of a 
co-operative parliament. The Co-operative Union is to the Co-operative Wholesale Society what the soul is to the body.

From this time onwards English co-operation has no longer a history-as is said of happy countries-because it moves forward of its own accord, and by its own strength. 'Today, co-operation is one of the live forces of the country; it is "a state within the State," as Lord Rosebery said at the Co-operative Congress at Glasgow, in 1890. As we shall see in the following chapter, it embraces nearly onethird of the people of Great Britain. In fact, many people fear that it may degenerate in proportion as it grows and spreads. They say that the attempt to realize the ideal of a new state of society which, like the Millennium to the early Christians, exalted the minds of the Pioneers, is now-adays confined to the search after more comfort or large dividends-in a word, they say that co-operation, instead of being a religion, is no more than mere business. In fact, it is inevitable that the more a movement spreads the more its original virtues tend to disappear in the mass of the people; nevertheless, education, for which English co-operators make considerable sacrifices, will help to keep cooperative enthusiasm alive in the coming generations.

We have given these details-necessarily somewhat cursory-of the origin of co-operation in England, but we do not mean that these institutions are peculiar to England. They are to be found in every other country, in proportion as these countries come into the co-operative movement.

\section{(2) In Belgium}

Meantime, while English co-operation of the Rochdale type was being evolved, in Belgium another type was emerging, having quite a different aspect. It is to Belgium (or rather, to certain leaders, César de Paepe, and after him, Anseele, Bertrand, and Vandervelde) that the merit is 
due of having united in one co-operative party the socialist school and the workmen's party, which, as we shall see later, had become separated (see, in the last chapter, the program and the characteristics of socialist co-operation). Not that the co-operative movement has assumed such large proportions in Belgium as in England. It is of much more recent date, being traced from 1880 only, and, having taken from the beginning a socialistic and political character, it found itself checked by the antagonism of other political parties, Catholic and Liberal, which have rival societies in every town.

But, on the other hand, this struggle has acted as a stimulus to co-operation, each party using it as a means of influencing the people. Thus, the characteristic feature of Belgian co-operation is that it is mixed up with politics, which is not at all the case in other countries-at any rate, up to the present. The socialist party has, above all, made the co-operative store not merely (as Anseele has said in his well-known phrase) "a fortress whereby to bombard the captalist society with potatoes and 4lb. loaves," but, better than this, a club house for the people, to serve them not only as a centre for supply, but for meetings, instruction, recreation, improvement. It has made co-operation a sort of patronage, different from capitalist patronage but employing the same methods, and we might even say using methods which no other patron would dare to do today; for instance, the member has to pay for his bread in advance each week-by buying counters, which means that the society borrows from the workman funds for its working expenses-and, moreover, the member must pay an addition of one-third of its real price for his bread. But the workman will bear from his society what he would not bear from any other master. He willingly allows himself to be drawn into a net-work of schemes of insurance, provi-, dence and mutual aid, which surrounds him completely from 


\section{0}

CONSUMERS' CO-OPERATIVE SOCIETIES

his birth to his death, and follows him into all the actions of his domestic, working, and political life. He is taught how to vote properly and not to drink alcohol. It is in order to keep in daily touch with him and to be able to control his actions more minutely that all Belgian cooperative societies make the selling of bread the basis of their operations.

\section{(3) In France}

France has been late in taking up distributive co-operation, though the social evil "competition" was being unceasingly anathematized by all French socialists in the first half of the 19th century. Therefore, it would seem only natural that co-operation, being the antithesis of competition, would appear to them the solution sought for. But then, they were seeking the solution in co-operation from the productive, and not from the distributive side.

Indeed, thoroughly discouraged by their failures, the working classes turned their backs on co-operation in all its forms. They continued to dally with the idea, however, as a solution for the social question, in their congresses up to that held at Lyons in 1878 ; ; but this was the last sign of interest shown by them. From the following year when, at the Marseilles Congress, under the initiative of Jules Guesde, and influenced by Marxian collectivism-then in its infancy in France-they changed completely and resolved that cooperative societies "could by no means be considered a strong enough method for gaining the emancipation of the labouring classes," they voted for the socialization of the means of production.

Nevertheless, here and there distributive co-operative so-

* Author's Note. "Considering that the condition of wage-carners is but a transitory state between serfdom and a nameless condition, the chambres syndicales ought to put everything in train for the establishment of general societies for distribution, credit, and production." This was a resolution passed at Lyons. 
cities were founded. The oldest of these which appears in the Co-operative Almanac is the Ruche Stéphanoise, of St. Etienne, which dates from 1855. But there were others, even older, which have long since disappeared, leaving no traces. The idea of grouping together for purchase in common is too simple not to present itself of ten to the mind and not to be acted upon at times. We can cite from 1828 the existence of a co-operative bakery called Caisse du Pain, in Alsace, at Gucbwiller.

The great burst of co-operative enthusiasm in 1848 , although it spent itself almost entirely in efforts to establish productive societies, did, nevertheless, bring some distributive societies into existence; in particular, at Lyons, a great centre of social activity at that epoch, there was formed the Société des Castors. Several works have been written on the history of co-operation at Lyons-one by M. Flotard, in the Year Book of Association, published in 1867, and one more recently by M. Godard, entitled, "The Origin of Cooperation at Lyons" in 1904. A co-operative shop, with some curious features, was started in 1835, before the Rochdale Pioneers' Society was formed, under the name of "Commerce Véridique et Social," and was threatened with prosecution by the authorities.

During the period 1867 to 1883, although public enthusiasm was more concerned with productive and credit associations, there were about one hundred distributive societies founded, among others, on the initiative of Benoît Malon,* the Revendication at Puteaux. In Paris, in 1867, there were only five or six distributive societies, compared with 50 productive and more than 100 credit societies. All of these

* Author's Note. Benoit Malon was a socialist of the French School, that is, he was not very sympathetic toward Marxianism, but rather sympathized with co-operative ideals. He, nevertheless, denounced in vehement terms, "the quacks of orthodoxy in the economic school, who had driven the workman out into the blind alleys of co-operation." (Manual of Social Economy.) 
were affiliated to one of three credit organizations (People's Banks): Le Credit au Travail, La Caisse des Associations Coopératives, and La Caisse d'Escompt des Associations populaires. At this time, co-operation was upheld by such well-known economists as Leon Say, Jules Simon, and Walras, but it had a more moderate program than that of Rochdale; and the law of 186\%, which we shall examine later, was due to this movement. Jules Simon made a very impassioned speech during the discussion on this law.

It was not until 1885 that distributive co-operation took a conscious existence-in the town of Nîmes-thanks to the initiative of a little group of co-operators, which included de Boyve, Fabre, and several workmen. Since then its progress has been less broken, if not very rapid. The first congress, which assembled in Paris in 1885, laid the foundations of an organization somewhat similar to that which we have described in England. A Co-operative Union with a Central Committee, a federation for purchase, annual congresses, and a journal were started about this time. During some ten years, the societies which had joined the Co-operative Union remained loyal to the Rochdale program. The Central Committee found a general secretary full of enthusiasm and experience. in the person of Charles Robert, the apostle of profit-sharing; but a premature and unfortunate attempt to form a federation for purchase in common (see later chapter on "Co-operative Federations") brought trouble and a certain amount of discouragement into the Union.

In the interval, the example of the Belgian co-operative societies and the counsel of their chiefs had brought back a certain number of French socialists to the co-operative movement. They found in co-operation, if not a solution of the social problem, at least a means of action, and these men began to form distinctive societies. But those societies of socialist tendencies in Paris, which had at first belonged to 
the Co-operative Union, soon withdrew from it because they thought the Union too bourgeois in its tendency, and too provincial in its little parliament, and in 1895 another group was founded composed entirely of Parisian societies under the name of Bourse coopérative des sociétés socialistes de consommation. (Co-operative Exchange of Socialist Consumers' Societies.) Socialists say that this secession marked the new co-operative era in France.

In this statement there is a measure of truth, and some ingratitude. As far as the co-operative program is concerned, the socialist seceders have added nothing to that of the founders of the Union; but as far as its realization is concerned it is true that their societies, being formed exelusively of workmen and animated by class prejudice, showed themselves more active, more disciplined, and possessed of more solidarity. Nevertheless, the period which followed (which lasted not less than seventeen years) was full of quarrels between the socialist group and the so-ealled bourgeois or neutral group which eertainly did not help the progress of cooperation in France. But we shall postpone to another chapter these discussions about the various schools of cooperative thought.

Finally, mainly because of the efforts of some loyal cooperators of both parties, and also because of the pressure of co-operators in other countries-especially Belgium and England-which was exercised at every national and international congress, the co-operative movement in France succeeded in regaining its unity. In 1912 the two groups were in accord in a declaration drawn up by a member of the Nîmes school. (For text of the declaration see the last chapter: "Co-operation and Socialism.") This declaration, called the Covenant of Union, was ratified separately and simultaneously by each federation in congress-unanimously at the Co-operation Union Congress, and at the Congress of the Socialist Exchange by a majority of $30 \%$ to 30 -and the 
Covenant of Union was finally adopted at the General Congress at Tours, held from December 28th to 30th, 1912, in the presence of numerous delegates of foreign co-operative federations who had come to witness this very happy union.

However, there were here and there a certain number of societies which refused to accept the Union, preferring to break away. On the other hand, some which had hitherto refused to federate decided to do so from the time when they had not the embarrassment of choosing between the two federations. On the side of the old Co-operative Union, the irreconcilables were the semi-patronal co-operative societies. On the side of the socialist group the dissentients were the large societies of the North not allied with the "Guesdist" party, that is to say, the Marxian societies. (Jules Guesde was the representative of Marxian socialism in France.)

It is fortunate that the Union was already established, although it had not borne any fruit at the time of the outbreak of war. It is owing to this Union that co-operation in France has been able to survive the great calamity, and even to render notable services to the country and the co-operative principle.

\section{(4) In Germany}

In Germany the working classes for a very long time refused to believe in the efficacy of distributive co-operation because they were imbued with the idea or theory of what Lassalle calls the brazen law, i. e., the ancient theory which teaches that any reduction in the cost of living inevitably brings with it an equal reduction in the rate of wages, and that, consequently, this would be the unfortunate result of the success of a distributive co-operative society. For this reason the co-operative movement in Germany was first started under Schulze-Delitzsch about 1850 in the form of co-operative credit, and in this form it has had a wonderful development, more striking even than that of consumers' co- 
operation in England. There are, in fact, 20,000 co-operative credit societies, both rural and urban.

As co-operative credit is the most conservative of all forms of co-operation it has rallied together the liberal and the bourgeois parties, and even the small traders, who have gained great advantages therefrom. It was a sort of lightning conductor for quite a long time, a preventive against the extreme socialism of Lassalle and Karl Marx. Thus, credit societies had a high place in the federations-notably in the General Union of Berlin, the most important one founded by Schulze-Delitzsch-while the distributive societies remained in a secondary position, their only function being (in the opinion of the Union) to help the workman to save and to be a source of supply for the credit societies. But the federation of credit and distributive societies under one banner was impeded by the fact that the small traders (who constituted the majority of the co-operative credit societies) declared that the development of distributive socicties aimed at their extermination. Futhermore, the General Union, which, inspired always by the spirit of Schulze-Delitzsch, stood for bourgeois liberalism, and defended the middle classes, was unable to accept the socialist labour program of social reform which the distributive co-operative societies both in Germany and France were beginning to teach. At the Congress of Kreuznach, in 1902, held under the presidency of Dr. Crüger, disciple and successor of Schulze Delitzsch, a resolution of the German Union condemned this program as being too socialistic.

Consequent on this motion, the larger number of distributive societies resigned, in order to form an independent Union with its head-quarters at Hamburg. This Union, however, unlike the Belgium group, does not profess the socialist faith; it has not allied itself with the large socialist democratic party, but by certain regulations-such as prohibiting societies from selling to the public or paying interest on 
shares-it gives to its societies a more "anti-capitalist and more mutual aid" character than that which obtains in any other country.

Today, Germany, although very tardy in entering the domain of distributive co-operation, advances with gigantic strides. The oldest co-operative distributive society on the Rochdale system appears to have been formed in Neustadt, near Magdeburg, in 1864. But it is only in the last years of the 19th century that German co-operation began to expand. In this field, as in the field of industry, she aimed at outstripping England, and at her former rate of progress, would probaby have succeeded, as we shall see by the figures in the following chapter. This is interesting, because the superiority of which Germany boasts, in the domain of organization, was not generally recognized, except in so far as it concerned compulsory State, or military, organization. Yet here we have a kind of organizationfree and spontaneous co-operative association-for which Germany displays an aptitude not less remarkable than that of the individualist English people. We must remember that the qualities, and even the faults of the German racethe spirit of discipline which can subordinate private to general interests, the gregarious instinct which moves it to join together, the enormous capacity for carrying things through, the cult of organization, even the very worship of the kolossal-are all conditions eminently favourable to the success of co-operation in Germany. As we shall see in the following chapter, the largest distributive societies in the world are to be found in Germany.

Let us pause here. This is not the place for a history of distributive co-operation in every country during the second half of the 19th century. It would be very monotonous, because in every country except Belgium the Rochdale type has been more or less faithfully copied. It would be more interesting to continue this history later on, in trying 
to discover in which countries this form of co-operation has the greatest chance of success. It is not certain that the small seed imported from England will fiourish in every country, and, at any rate, it is perfectly clear that its development will be unequal, as we shall explain in the following chapter. 
STA TISTICSA N G EOGRAPHICAL DIS-

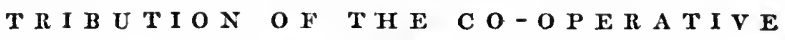
MOVE M E N T

When it is remembered that the type of association created by the Rochdale Pionecrs was specially contrived to meet one particular need one cannot fail to admire the way in which this little seed of co-operative effort has been able to adapt itself to all countries, to modify itself to the special circumstances of its surroundings, and to give birth to a wonderful variety of different forms of activity. It flourishes in all countries alike-in frozen Iceland and Labrador, and in the burning Islands of the Pacific. In Palestine several colonies of Zionist Jews, finding themselves cut off from all supplies by the war, organized themselves into co-operative societies, in order to be able to live and await relief.

Unfortunately, statisties relating to consumers' co-operative societies are very incomplete. The number of societies in each country is fairly well known, but there are not many where the number of members is stated, and there are even fewer where that most important figure, the turnover, is known with any degree of accuracy. Thus in Italy, where co-operation has developed to a remarkable degree, there are, as yet, no exact statistics. Even in those countries where societies are grouped in federations there are a certain number of "wild men" who do not supply the returns sought, so that the figures given are below the actual figures and ought to be increased by an unknown quantity. ${ }^{1}$ It is only in

1 This condition prevails to a marked degree in the United States. Many of the societies are isolated, out of the channels of co-operative 
Great Britain and Switzerland that co-operative statistics are more or less complete, bccause in these two countrics alone almost all the societies are grouped in a national federation.

Subject to this reservation, the following figures may be given for 1914, the last normal * year:-

\begin{tabular}{|c|c|c|c|c|}
\hline Country. & $\begin{array}{c}\text { Number } \\
\text { of }\end{array}$ & $\begin{array}{l}\text { Number of } \\
\text { Members (in }\end{array}$ & $\begin{array}{l}\text { Proportion } \\
\text { per } 1,000\end{array}$ & $\begin{array}{c}\text { Turnover } \\
\text { (in }\end{array}$ \\
\hline tish Isles ... & $\begin{array}{c}\text { Societies. } \\
1,385\end{array}$ & $\begin{array}{c}\text { Thousands). } \\
3,054\end{array}$ & $\begin{array}{c}\text { Inhabitants. } \\
264 .\end{array}$ & $\begin{array}{c}\text { thousands). } \\
£ 88,000\end{array}$ \\
\hline rmany $\ldots .$. & 2,375 & $2,000(?)$ & 121 & $29,000(?)$ \\
\hline ssia ........ & 13,000 & 1,500 & 34 & 32,000 \\
\hline ince $\ldots . .$. & 3,261 & 881 & 90 & 12,840 \\
\hline tria $\ldots . .$. & 1,471 & 423 & 70 & 7,200 \\
\hline$\ldots \ldots \ldots$ & 2,481 & 400 & 43 & $7,200(?)$ \\
\hline itzerland . & 396 & 276 & 290 & 5,240 \\
\hline amark $\ldots .$. & 1,560 & 250 & 350 & 6,000 \\
\hline angary $\ldots \ldots$ & 1,300 & $200(?)$ & 40 & 3,000 \\
\hline lgium $\ldots$. & 205 & 170 & 90 & 1,920 \\
\hline eden $\ldots . .$. & 608 & 153 & 108 & 2,440 \\
\hline land $\ldots \ldots \ldots$ & 1,500 & 120 & 33 & 1,680 \\
\hline lland ........ & 135 & 99 & 72 & 1,040 \\
\hline land $\ldots \ldots \ldots$ & 512 & 97 & 120 & 2,520 \\
\hline ain $\ldots \ldots \ldots$ & 200 & 40 & 30 & 800 \\
\hline orway .... & 172 & 39 & 42 & 550 \\
\hline
\end{tabular}

These figures have been much affected by the war, though not generally, as might have been expected, adversely affected. On the contrary, in almost every country, belligerent

thought and feeling as it circulates among the societies affiliated with The Co-operative League or with one or another of the local federations or wholesales. The officers of such associations do not answer or even acknowledge requests for information. Some of these have been hunted down by members of the staff of The League or other interested persons. But the country is so large and the faithful workers so few that scores of co-operatives come into existence, live and die without being known to the American Co-operative Movement.

* Author's Note. These figures are taken from co-operative journals, from the "International Co-operative Bulletin," and from reports presented by delegates to the Congress. The mark of interrogation in some cases indicate those whose details are uncertain and sometimes contradictory. We have classified the countries in the order of the figures in the second column, which gives the number of members. The number of societies indicated in the first column is not really a sign of superior- 
or neutral, there is a considerable increase, and in some, notably Finland, Russia, Georgia, and Ukrania, the increase is enormous. This is an unexpected phenomenon. It can be explained as regards neutral countries by the fact that co-operative societies have shared in a general prosperity; but one would have expected that in belligerent countries, where almost the whole adult population has been mobilized, a marked decrease in consumption would have been found. But those who remained at home increased their consumption on account of the increase in wages and allowances, and further, the number of members of the societies has increased, because the general raising of prices has forced the public towards co-operation. It is possible, however, that these increases will not be permanent.*

ity-rather the contrary-as it shows that the societies are very small. However, it has a certain value, as it shows how co-operation has spread over the country. The third column shows the number of cooperators per 1,000 inhabitants (multiplied by four, because each co-operator stands for a family, sometimes a very large family; there is very rarely more than one member in the same family). This column is the best proof of the penetration of the co-operative spirit in the country, which from this point of view ought to be taken as the touchstone of co-operative progress in any co-operative classification. The high place the small countries-Denmark, Switzerland, and Finland-take in this classification is worthy of remark. The fourth column, giving the total sales, is more or less equivalent to the second, because it is natural that the amount of sales should be proportionate to the number of customers. However, the parallel is not absolute, because, as we must not forget, in many countries co-operative societies sell not only to their members, but also to the general public.

* Author's Note. The following are the most recent figures (of the year 1920 or 1921) for the principal co-operative countries:

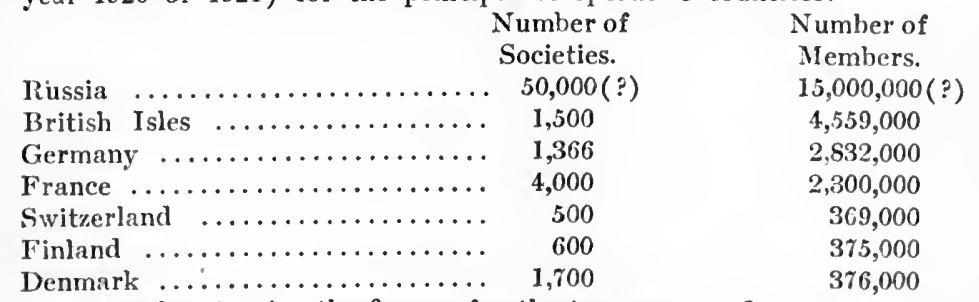

It is useless to give the figures for the turnover, as fluctuations in the value of currency deprive these figures of all significance. It is of little 
We must add to our list some thousands of consumers' co-operative societies in the Balkan States and Portugal, and, outside Europe, about a thousand in the United States, Canada, Japan, India, Australia, and even in snowbound Iceland. The number of consumers' societies in the whole world is at least thirty thousand, ${ }^{*}$ having about ten million ${ }^{2}$ members and a turnover of nearly 200 million pounds. Bcsides this, it must not be forgotten that each co-operator usually represents a family (since unmarried people have comparatively little reason for joining a co-operative society), and working-class families are gencrally large, so that these ten million co-operators represent a population of from 40 to 45 million persons, the equivalent of a large State.

As for the turnover, compared with the trade of the world, which runs into thousands of millions, it is clearly only an infinitesimal portion; it hardly amounts to $8 \mathrm{~s}$. per head for Europe! Still, if one remembers that the co-operative movement is not yet three-quarters of a century old-and how short a time that is in the history of the world: less than the life of a man-these results will not appear despicable, but rather of a kind to justif $y$ the hopes of co-operators.

A few words about the principal co-operative countries. They advance at very different speeds along the road to co-

value to record the billions of marks or crowns for Germany or Austria, and the trillions of roubles for Russia! The total turnover of the co-operative societies of Great Britain was 250,000,000 pounds (it should be remembered, however, that the pound has also depreciated in value); and the turnover of the Swiss societies was 337,000,000 francs (the Swiss franc has fluctuated as little as the American dollar).

Even if the figures for the turnover of all countries were expressed in gold (or in dollars) it would be noted that the increase over the figures of 1916 is comparatively little, while the growth in the number of members was considerable.

2 figures published at the Basel Congress in 1921 showed 25,000,000 members of co-operative societies.

*Author's Note. This list does not comprise the following categorics of co-operative socicties which, properly speaking, are not con- 
operation. Far and away in the first place comes Great Britain, and this is not surprising, after what we have seen in the preceding chapter on the history of co-operation. First of all, the United Kingdom excels by the number of its co-operators - more than four million families $(4,500,000$ in 1920)-which represents about one-third of the population of Great Britain, leaving out Ireland, where consumers' cooperation is of little account. There are certain counties where the proportion of co-operators rises to a half and even three-quarters of the population. There are big cities, such as Leeds, or small towns, such as Kettering or Desborough, where almost the whole population are co-operators. (Report of General Co-operative Survey Committee, Co-operative Union, Manchester, 1916.)

All the societies are strong, for their average membership is over 3,000 (575 in France). There are 100 socic-

sumers' associations, although they really come under the definition we gave, namely:-

(a) Co-operative building societies, that is to say, societies for the supply of houses, to the number of more than 10,000, of which the large majority $(7,000)$ are in the United States and England, nearly 300 being in France. We shall speak of these later on. ${ }^{3}$

(b) Co-operative agricultural and urban societies for the purchase of fertilizers and raw materials, which number at least 20,000. There are 6,000 of these societies in France. 4

Nor does it include co-operative credit societies, both rural and urban, which number about 50,000 to 60,000 (18,000 in Germany and as many in Russia), although their object is to satisfy a very pressing need of their members, namely, the need of money.

According to the Russian economist, Tugan Baranowski, who died 1919 , there were at that date 160,000 co-operative societies of all classes with $30,000,000$ members.

3 The Building and Loan Associations, to which Professor Gide here doubtless refers, are not strictly co-operative. They do pretend to do away with private profit, but they are not democratically controlled, nor are there any co-operative features to the houses or communities, once they are huilt. They are semi-democratic credit associations.

4 There are also thousands of these in the United States. Obviously they are not consumers' associations; they enable producers to procure their raw materials more economically. With them should be classed such associations as the Artists' Co-operative Store in New York in which brushes, paints, etc. are sold, the Dentists' Co-operative socicty of New York, and similar societies. 
ties with more than 10,000 members, of which one, Leeds, has 190,000 members and a turnover of $£ 3,000,000$. 'The turnover of these societies shows their strength, no less than their membership. In 1914 the turnover was more than 88 million pounds, which represents $£ 64,000$ per society ( $£ 4,000$ in France) and an average of $\mathfrak{2} 29.10 \mathrm{~s}$. per member. The figures for 1920 are much higher, owing to the rise in prices

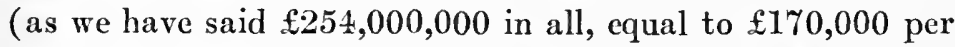
society, or $£ 56$ per member). This average is far above that of any other country (in France the average is about 700 francs, which are worth in present currency about $£ 14$. This high average implies two things; first of all, that the societies are not merely grocery shops, but supply every kind of goods, and, secondly, that the members are very loyal to their store. This is a rare quality, and is one of the surest tests of co-operative zeal. There are a good number of English workmen who bring all their wages to their own shop and spend scarcely any money outside of it.

In the above figures, sales made by the English and Scottish federations to their societies (totalling more than 130 million pounds ) are not included, as that would involve a duplication;* neither are the figures for the co-operative bank, which has a turnover of more than 400 million pounds, nor those of the Co-operative Insurance Society, with its 40 million pounds' worth of risks. If the whole were added together they would reach a total of about 1,000 million pounds.

Germany, as we have said, is above all the home of co-operative credit societies (18,000 with more than 2,500,000 members), but still, as regards co-operation for consumption it takes second place, though it made great strides in the years before the war, at a rate of progress much higher than that of Great Britain, as may be seen from the following figures:-

*Author's Note. See page 159, chapter on "Purchasing Federations." 
Grcat Britain.

Members

(in thousands). Sales.

$\begin{array}{llll}1902 & \ldots \ldots & 1,709 & £ 50,040,000 \\ 1914 & \ldots \ldots & 3,054 & £ 88,000,000 \\ & & & \end{array}$

Increase 178 p. 100

176 p. 100
Mcmbers

Germany.

(in thousands). Sales.

575

1,717

$\mathfrak{E} 7,040,000$

$£ 26,360,000$

300 p. 100

374 p. 100

It is clear that during this last decade the German societies have just tripled their number of members, and almost quadrupled their turnover, while British societies have only increased in each case by about 75 per cent. ${ }^{6}$ It is true that in making this comparison we must take into consideration, first, that in every movement, as in every organism, increase is greater in early youth, and, secondly, that the population of Germany is half as big again as the population of Great Britain and therefore offers a bigger field for extension. Consumer's' Co-operation in Germany is still far behind that of Great Britain, for the total number of members is about half, and the turnover not a third of that in Britain.* Still there are many important societies there, to which the epithet "colossal" may be applied without exaggeration, notably that of Hamburg with 80,000 members, Leipzig with 65,000, and above all that of Breslau, which has 100,000 members. ${ }^{7}$

6 Germany now has almost as many mcmbers as the British movement. Inasmuch as little more than half of the German societies are affiliated with the Central Union, precise figures are not available; but the leaders estimate a membership of about $4,500,000$ for the societies of the whole country.

* Author's Note. The only trustworthy figures are those of the socicties affiliated to the Hamburg Federation (see page 45). These are the ones which appear in the comparative table above. But this Federation only included 1,200 societies out of more than 2,000 existing in Germany at that date (1914). The figures in the tables, therefore, do not represent the real total. At the same time we must guard against believing that they might be doubled, because the societies belonging to the Hamburg Federation are the most powerful in Germany.

in 1921 the Hant, ig Society had 120,724 members, and the Vienna Society 152,513 members. 
Moreover, generally speaking, the average of sales per member is much smaller in Germany than in Great Britain, being only $£ 15$. 11s., which is explained less by the disloyalty of members than by the fact that these societies generally confine their trade to groceries, as in Breslau.

France, as we have already seen, comes first after Russia as regards the number of its societies, but there is nothing for her to boast about in this, as the large number of societies is not a sign of strength, but of weakness; it is simply a sign of the scattered and overlapping nature of the societies. As far as France is concerned, for a long time past the only statistics published have been those compiled by $\mathbf{M}$. Daudé-Bancel, Secretary of the late Union Cooperative which appeared since 1892 in l'Almanach, now the Year-book of French co-operation. The Labour Bureau (at first for the Ministry of Commerce, but now for the Ministry of Labour) used to prepare statistics from information obtained from official sources. Since 1907 it has published annual statistics which are fairly complete.

The following tables show the comparative increase of the number of societies in Great Britain and France. First of all for Britain, the following table shows the increase in the number of societies and the number of their members:-

\begin{tabular}{|c|c|c|c|c|}
\hline & & $\begin{array}{l}\text { Number } \\
\text { of } \\
\text { Societies. }\end{array}$ & $\begin{array}{l}\text { Number } \\
\text { of } \\
\text { Members. }\end{array}$ & $\begin{array}{l}\text { Number } \\
\text { per } \\
\text { Society. }\end{array}$ \\
\hline 1862 & $\ldots \ldots \ldots$ & 331 & 89,000 & 269 \\
\hline 1872 & $\ldots \ldots \ldots \ldots \ldots \ldots \ldots \ldots \ldots$ & 930 & 324,000 & 348 \\
\hline 1882 & $\ldots \ldots \ldots \ldots \ldots \ldots \ldots \ldots$ & 1,043 & 598,000 & 573 \\
\hline 1892 & $\ldots \ldots \ldots \ldots \ldots \ldots \ldots \ldots$ & 1,420 & $1,127,000$ & 794 \\
\hline 1902 & $\ldots \ldots \ldots \ldots \ldots \ldots \ldots$ & $1,4,76$ & $1,893,000$ & 1,215 \\
\hline 1912 & $\ldots \ldots \ldots \ldots \ldots \ldots \ldots$ & 1,399 & $2,750,000$ & 1,970 \\
\hline 1914 & $\ldots \ldots \ldots \ldots \ldots \ldots \ldots \ldots$ & 1,385 & $3,054,000$ & 2,205 \\
\hline 1920 & $\ldots \ldots \ldots \ldots \ldots \ldots \ldots$ & 1,379 & $4,504,000$ & 3,260 \\
\hline
\end{tabular}

It is seen that since the year 1902, which marks the maximum, the number of societies has decreased by nearly 100 
while the number of co-operators has increased by nearly two-thirds, and if one goes back to 1892, it is seen that the number of societies has diminished by 35 , while the number of members has increased nearly three-fold. For France, we give a parallel table, except that we cannot go back further than 1900, as no trustworthy statistics exist before that date.

\begin{tabular}{|c|c|c|c|c|}
\hline & & $\begin{array}{l}\text { Number } \\
\text { of } \\
\text { Societies. }\end{array}$ & $\begin{array}{l}\text { Number } \\
\text { of } \\
\text { Members. }\end{array}$ & $\begin{array}{l}\text { Number } \\
\text { per } \\
\text { Society. }\end{array}$ \\
\hline 1900 & $\ldots \ldots \ldots \ldots \ldots \ldots \ldots \ldots$ & 939 & 375,000 & 400 \\
\hline $190 \pi$ & $\ldots \ldots \ldots \ldots \ldots \ldots \ldots$ & 2,214 & 705,000 & 318 \\
\hline 1914 & $\ldots \ldots \ldots \ldots \ldots \ldots \ldots \ldots$ & 3,156 & 876,000 & 278 \\
\hline 1920 & ${ }, \ldots \ldots \ldots \ldots \ldots \ldots \ldots$ & 4,000 & $1,300,000$ & 325 \\
\hline
\end{tabular}

These figures show that since 1900 the number of socicties has increased more than four-fold but that the average number of members per society has diminished by one fourth, while the number of British societies in the same period diminished a little, and the average number of members per society has nearly quadrupled. Nothing is more significant than this parallel, which shows clearly the Anglo-Saxon tendency to concentration as opposed to the dispersive tendency of the French. It shows that in France the increase in the number of societies is far more rapid than the increase in members, which shows further that the societies are becoming smaller and smaller. This gradual diminution in the average number of members can partly be explained by the fact that according as statistical investigation spreads more small societies are discovered. These figures are those given in the Bulletin of the Ministry of Labour. The Year-book of French Co-operation of 1914 gives slightly higher figures: 3,261 societies, and 881,000 members. The average number of members in the third column-calculated by simply dividing the total number of members by the number of societies-is slightly lower than in reality, because a certain number of societies have not given the number of their mem- 
bers, and therefore the divisor should be reduced by so much; but the difference is insignificant. Therefore, with us, multiplication is synonymous with division! That is why (without mentioning Paris, where there are 44 societies, of which only 6 or 7 are at all important), we find 54 societies in Lyons, 21 in Creusot, 11 in Montceau-les-Mines, 27 in Roubaix, 18 in Tourcoing, 11 in Bourges, \&c., \&c. More than a quarter of the French societies (more than $900)$ have less than 100 members; there are even some which have only 7 , barely the legal minimum!

The French societies are not only weak in the number of members, but also in turnover,* and the amount of purchases per member. This last is a very serious symptom of the lack of co-operative spirit, for, as we shall see further on, it shows but little enthusiasm on the part of the members. Still, there is another reason for it, which is that the greater number of societies in France deal in groceries only, and therefore the amount of purchases which the members can make at their co-operative shop is very limited. More than a third of the societies $(1,300)$ confine themselves to baking, and their turnover is thus necessarily restricted. It is hardly possible for a co-operative bakery, no matter how enthusiastic its members may be, to sell more than one $4 \mathrm{lb}$. loaf to each member per day, which hardly makes more than $£ 12$ per member per annum at pre-war values. Those societics which sell all classes of goods are rare. In France the average of sales per head is a little below that of Germany, but it is above all in the average membership per society and in the turnover, that we are inferior. If we compare the figures of the Fédération Nationale française with

* Author's Note. The total amount of sales (for the 2,988 societies which furnished information) in 1913 was $£ 12,600,000$, which represents an average of $£ 4,000$ per society, while in Great Britain the average was $£ 64,000,16$ times more! Even in Switzerland the average is much higher, namely, $£ 15,000$ sales per society. Recently a striking tendency towards amalgamation has been shown in Paris and the principal cities of 1 rance. 
those of the Hamburg federation we find for the latter an average of 1,560 members and $£ 24,000$ turnover, and for the former only 315 members and $£ 5,360$ turnover. We have not huge societies like Germany-only one French society (l'Union des Coopératizes, of Paris) has 70,000 members, a turnover of $£ 3,000,000$. This society was formed during the war by the amalgamation of a dozen Parisian societies.

Switzerland takes a high place among the co-operative countries, for it has 400 consumers' societies with nearly 30,000 members, in a population which does not reach 4 millions. This is a proportion relatively higher than that of Great Britain (78 co-operators per 1,000 inhabitants instead of $\gamma_{4}$ ) ; and the turnover, close on six millions, is but little inferior to that of Britain ( $\mathfrak{f 1}$ 12s. per inhabitant in-

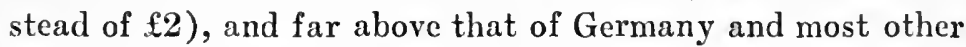
countries. Switzerland has five societies with over 10,000 members, of which the Bâle society has 37,000 (that is to say-counting members of families-nearly the whole pop-

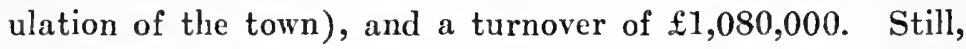
the Swiss movement is of recent date. It did not really start until the formation of the Union Coopérative de Bâle in 1890, which now has a membership of more than 400 societics and a turnover of over $£ 2,000,000$. One of the features of Swiss co-operation is the loyalty with which all the societies support the Union and bring to it their moral and financial help. Switzerland, being itself a federal democracy which bears on its shield the device, "Each for all, and all for each," is for this reason particularly inclined towards federation in its economic life. (For actual figures, see page 49.)

In Italy also the co-operative movement is very remarkable, though for different reasons. Italy is of all countries that in which the collaboration of the three great forms of working class association, namely, Trade Unions, Friendly Societies, and Co-operative Consumers' Societies, seems best realized. At Reggio Emilia, notably, these bodies are grouped 
in a very strong union. There are very few large societies except "professional" societies like Cooperative Operaie, at Trieste (37,000 members), or socictics of workmen and lower middle classes like l'Unione Cooperativa of Milan (17,000 members), and the socialist society at Turin (19,000 members ); but the economic evolution of Italy is behind its political evolution, and it has not yet been able to realize its own unity in this field. Italy has with great difficulty been able to create a general wholesale federation, which is not making much progress. The lack of statistics makes any comparison with other countries impossible.

Belgium is the only country where the co-operative movement has taken a decidedly original form and a socialist and political colour; but for this the reader is referred to what has been said in the preceding chapter.

There is one small country where co-operation has developed to an extraordinary degree more than in any other country, not excepting England, and that is Denmark. In it there are 1,700 consumers' socicties, a huge figure for a country with 3 million inhabitants that would represent more than 20,000 societies in France or England. It is true that the societies are very small, the total number of members being about 300,000 , or barely 180 per society. That is because they are above all rural societies. It is in the country districts, unlike what has happened in other countries, that co-operation in all its forms has developed most. ${ }^{8}$

At the other extremity of the scale-passing from the smallest to the greatest country-we find Russia. 'There the development of co-operation was very slow until the first years of this century, but during the last ten years it has made great strides, and the war has given it an unexpected impetus. Doubtless the Mir and the Artels had already

8 The greater emphasis, however, is upon the farmers' marketing association in Denmark. 'This is equally true of Ireland. And the same conditions prevail in some of the agricultural states of $\Lambda$ merica. 
shown the innate aptitude of the Russian people for association. It is therefore not surprising that as these antiquated forms disappear the spirit of association should manifest itself in a new form. The democratic movement here finds an outlet while the special progress due to the war is explained by the necessity of struggling against the increase of prices.

The number of consumers' societies in Russia is estimated at about 50,000, mostly rural, and the number of credit societies (with which we have no concern here) is at least 15,000. These last are in process of transforming Siberia.*

There is nothing special to say about other countries. In Austria-Hungary there is a fair number of consumers' societies, but diversity of races, and the inequality of their economic development, make it impossible to form a united organization. Austria properly so-called follows, though at a considerable distance, the example of Germany. Hungary, under the impulse of the great socicty of Budapest, II angya (The Ant), has a great number of consumers' societics, 1,300, as reported by a correspondent of the "International Co-operative Bulletin." The Czechs in their turn have formed a Union at Prague. In Czecho-Slovakia the co-operative movement has made wonderful progress since the country recovered its independence. In it there are now 7,400 societies, with 600,000 members.

The Balkan countries have not yet got beyond co-operative agriculture, which is better adapted to their economic condition; but they are today considering consumers' co-operation,

* Author's Note. See the numerous articles published in the "Russian Co-operator." The advance of the Russian Co-operative movement during the war was prodigious. The Moseow Society has 210,000 mernbers, which far exceeds the membership of any other existing society in the world. It is due to this movement that Russia did not die of hunger. The Bolshevik government respeeted the co-operative movement up to the date that it nationalized it. ${ }^{9}$

"In 1921 'The Sovict Government gave back to the Co-operatives the greater part of their independence. 
and even Serbia was in process of starting a school, almost a university, for teaching co-operation.

Outside Europe there is a great country which, strangely enough, does not take a high place in this brief review, and that is the United States. There, co-operation has up to the present been almost negligible, as is also the case in other new countrics and colonies. The explanation for this is that in countries where the workers are highly paid and contemptuous of small economies, and where they generally lead a somewhat roving life, cconomic and social conditions are altogether unfavourable to the suceess of co-operative associations. On the other hand, the struggle for life, which is an exact antithesis of co-operation, is nowhere so keen as in the United States. ${ }^{10}$ Nevertheless, there are some nuclei of cooperation which are gradually forming, on the one hand in California, where the majority of co-operative societies are productive agricultural societics, and, on the other hand, in the oldest States, where the conditions of life are already beginning to resemble those of Europe as, for instance, Massachusetts, New Jersey, \&c. ${ }^{11}$

Co-operation also may find a favourable atmosphere in the chief centres of German, Italian, Slav, and above all Finnish, immigration, where the immigrants have brought with them and still keep the customs of their native land. Minneapolis, where there are many Germans and Scandinavians, is already a co-operative centre. It seems likely that cooperation will tend to spread among the negrocs, but, that, unfortunately, will not increase its popularity in America.

In 1916, the American Co-operative League was created in New York. This has as its program the grouping of all co-operative societies, as is done by the "Unions" in other

10 And conditions are still further aggravated by the inevitable "chain-store" which is pushing its way into even the smaller towns.

11 Sinee these words were written conditions have ehanged in the United States, and Co-operation is flourishing best in the Central and North Central States. See Chapter I. 


\section{CONSUMERS' CO-OPERATIVE SOCIETIES}

countries. Lately the Rochdale type of co-operation has developed considerably in the United States. Today (1920) there are more than 2,000 societies. $^{12}$

12 Experimental attempts have been made with chain stores. Today there are none left. Wholesale Co-operatives, with chain stores and with authority over all the local groups highly centralized at headquarters, have failed in Seattle, Pittsburg, Hoboken, and Chicago. In 1922 the Pacific Co-operative League followed these others and asked for a receivership. Today the two or three wholesales in existence are run on the Rochdale plan, granting local autonomy to the independent store society (except in the case of those. few members of the Central States Wholesale Society which have not yet asked for local independence). The strength of the American movement is in the independent societies at present. 


\section{VARIOUS SYSTEMSOF SA L E}

\section{(1) Sale at Current Price}

The general rule followed in all the distributive societies in the sale * of their goods is to sell them at the same retail prices as those current in the neighbourhood. The rule of sclling at the current trade price does not seem to be consistent with our ideas of distributive co-operation, as a saving in expenditure is the first object of this type of co-operation, and it would seem to be more natural to go straight for the goal by selling at the lowest possible price, that is, at cost price. In fact, there are some societies which, faithless to the Rochdale rule, operate in this manner.

It is noteworthy that these societies are recruited from the two extremes of the social ladder:-

(a) From the middle classes, Government officials, and employees who, having sufficiently high salaries, but being obliged to live up to a recognized standard, ask no more of co-operation than a means of best satisfying their needs at the least possible expense, and do not trouble at all about

*Author's Note. The word "sale" is not absolutely accurate in this connection, as it is a question of an association which sells to its own members, or, rather, of an association of people who sell to themselves. The word "division" or "distribution" would really be more correct. Thus the English call these associations distributive societies, and in France the employés are often called "repartiteurs" (distributors). We shall see further on that the law and the Treasury do not generally regard the consumer's' society as being in the same category as a trader who buys to re-sell. However, the word "sale" is sanctioned by custom, and it is legally accurate, as the society as a whole is an entity distinct from its members. 


\section{CONSUMERS' CO-OPERATIVE SOCIETIES}

realizing any social transformation. To this class belong generally such stores as the Civil Service Stores and the Army and Navy Stores, which are among the largest shops in London. But as we shall see later, these are looked upon by English co-operators as being really outside the ranks of co-operation. ${ }^{1}$

(b) From among the very poor and needy whose wages are insufficient to supply the minimum of nourishment. In these cases it would be impossible as well as inhuman not to procure for them the largest amount of food supplies in return for the means at their disposal, as they should get the maximum value for every halfpenny. In Russia, for example, where wages generally are very low, the distributive societies sell at the lowest possible price. ${ }^{2}$

But this system of selling at net cost has very serious disadvantages :-

1. It exasperates the traders of the neighbourhood by a price-cutting competition, which they are unable to sustain. And this is unnecessary, because if a reduction in expenditure were the only object of co-operation it would be much simpler for people not to trouble to form a society of consumers but merely to make an arrangement with the various

1 The Staff of the Co-operative Reference Library, Dublin, is authority for the statement that the Army and Navy Stores can no longer be regarded as co-operative in any way, since it pays a dividend of several hundred per cent. on its share capital. The United States have several false co-operatives, masquerading as genuine enterprises and collecting millions of dollars from individuals who believe they are contributing to Roehdale societies.

2 This is often attempted in the United States. It is known as the "cost-plus" system of sale. It is the method adopted in several of the societies in the mining towns of the central part of the country. 13ut as a matter of fact, there is little to be gained from such an attempt. In this country there is such keen competition among grocers that the selling price is usually forced down to a level very close to "cost-plus." Many of the societies arc barely covering expenses as it is, and some are running behind. For this very reason, many cooperators are becoming convinced that the grocery store is not the best beginning for a co-operative soeiety. 
traders in the locality, whereby they could get a discount on all current prices. This would mean that the larger the number of buyers so much the greater advantage for the traders. This very simple system has often been tried and has been warmly recommended, particularly by those who wish to secure the benefits of co-operation for the public without interfering with retail trade. ${ }^{3}$ (See later, "The Conflict between Co-operative Societies and Traders.")

2. It prevents the society from selling to outsiders, because, on the one hand, it would be absurd to confer on strangers the same benefits as on the members, namely, supplies of goods at cost price; and, on the other hand, it is impracticable to have two different prices for each article. It is true that selling to the public is not practised by all cooperative societies, and is even generally discouraged, as we shall sce. But, even though the society sells only to its members, the system of selling at cost price has another drawback, namely, it tempts certain members to buy goods for their friends and neighbours, and even perhaps to make a profit thereby as middlemen. This abuse has been fairly frequent, especially in the co-operative societies in Spain.

3. Above all, it prevents the society from attaining any of the objects which we shall examine later: individual or collective saving, insurance, production, education or propaganda work, or even the building up of capital, because this last can only be done by surplus profits being left in the society as deposits. (See p. 108, chapter "Capital.") We may say that all these objects are sacrificed; in fact, the whole co-operative program is sacrificed for the sale at low prices. The socicties that work on this system cut their corn while

3 There are many societies in the United States which follow this practice, but it is generally condemned. The co-operative store which takes orders for other commodities to be supplied by private merchants, or which rents out part of its floor space to the trader is confusing the public whereas it should be doing everything possible to make clear the distinction between private and co-operative business. 
green, and they do not differ much from the philanthropic societies of the pre-Rochdale period. Another strong objection raised against this system of selling at cost price is that it tends to the lowering of wages. This was the greatest argument put forward by socialists against co-operation, when, during the second half of the 19th century, they hindered the co-operative movement. They laid down the law that any permanent lowering of price in articles for consumption must bring with it a proportionate lowering of wages. 'This is what was called the "brazen law." Today this argument does not hold good, as this law is no longer believed in. And even if it were true, it would have the same unfortunate consequences in the matter of sales with dividend as in that of sales at cost price.

This is why in every country nearly all co-operative societies follow the Rochdale rule and sell, not at cost, but at current price. The profit thus realized on each purchase is credited to the purchasing member, and is returned to him at the end of the year, or generally at the end of every six months.

By adopting this method societies give up the idea of offering their members the advantage of a daily saving in their purchases, in order to be able to return to them a good round sum once or twice a year, a sort of dividend. This amounts to the same thing, no doubt, but the effect on the consumer is much greater. As a matter of fact, this system is extraordinarily appreciated by workmen, and still more by their wives. One might almost say that it is too much appreciated, because, of the millions of co-operators existing in the world, the large majority only become such owing to this system of dividends. Wherever we find workmen well enough paid to be able to spend freely, well enough educated in co-operation to look for big results from it, far-seeing enough to prefer the future advantage of an addition to their revenue for themselves, or an additional support to 
their society, to a daily saving of a few pence, there the Rochdale rule of sale at current price can be unhesitatingly applied.

It is worthy of note that in both England and Belgium a good number of societies raise the prices of their goods higher than the current market price in order to augment their dividends. Some societies are able by this means to declare a dividend of 20 per cent., or even 25 per cent. (4s. or $5 \mathrm{~s}$. in the $f)$. Many co-operators, so far from objecting to this plan (which consists of taking an extra halfpenny out of their pockets in order to restore the same halfpenny six months later), rather take a pride in it, and press for its adoption in their general meetings. The fact is, as we shall see further on, they find in this plan a means of compulsory thrift. On the subject of Belgian societies, M. Varlez writes in a report on Social Economy in Belgium for the Paris Exhibition of 1900, as follows: "The fantastic system of paying 30 centimes for an article (bread) which every one knows to be only worth 20 , has become so ingrained a habit that the working classes in certain towns do not wish to give it up. On various occasions it has been proposed to the members of co-operative societies to lower the price of bread. They declined positively as they find this mode of saving both easy and efficacious." However, this system of raising prices has some serious disadvantages, which we shall indicate later, notably that of shutting the door of co-operation in the face of the poorest class. On the other hand, we must recognize that this exaggeration of the Rochdale principle implies a strong enthusiasm for cooperation. I see in it a robust faith in the power of cooperation. In countries where such a faith scarcely exists, as in France, a co-operative society which attempted to sell above the current price would hardly find a supporter, no matter what bonus were returned. Societies which practise a mixed system of selling at a price slightly lower than the 
current price in order to attract customers but nevertheless sufficient to allow a certain margin of profit, which can be cmployed in one or other of the ways which we shall indicate later, are much more numerous, particularly in France. ${ }^{4}$ The essential thing is to make co-operators understand that they must choose, and that they cannot have the advantages both of low prices and of large dividends. If they wish to extend their movement to the poor they must give up their big dividends and sell at cheap rates, always leaving, however, a small margin for profit, say 5 per cent.

'The complaint has been made in England that consumers' co-operation is only intended for the well-to-do working classes, and remains inaccessible for the more needy,* and the Women's Co-operative Guild (of which more hereafter) is trying to lead the co-operative movement in the direction of lower prices. But this is not easy, because mere lowness of price is not sufficient to attract a poor clientèle; it is also imperative to stock goods of an inferior quality, because, unfortunately, these are the only goods which the casual and unskilled workers can afford to buy with their resources. And co-operative societics hold it as a point of honour to keep only goods of the first quality.

\section{(2) Sales for Cash}

The second rule for sales is sale for cash. For this there are both economic and moral reasons: First, economic reasons, because every establishment which gives credit must

4 This is the plan generally prevalent in the United States also. We know of no instances where goods are sold above the current price, except as the clever manager is able to raise the price on isolated commodities so as to increase the surplus-savings.

* Author's Note. An Englishman has said, "The truth is that cooperation only saves those who are already converted." This may be, but there is now no longer the necessity of making co-operation a mere work of salvation. It is rather a work of mutual aid. For social institutions, as well as for individuals, there is a law of division of labour, which must be respected. 
raise its prices, or risks failure. In fact, on the one hand, it is certain to lose some of its credit, and, on the other, being obliged by selling on credit to buy on credit from the wholesalers, it must buy under less advantageous conditions. It must have a larger capital, as it is unable to turn it over rapidly. A co-operative socicty ought not to put itself into such an inferior position. Secondly, moral reasons, because it is immoral to make the good customers, i. e., the scrupulous members, support the insolvency of those who do not pay their debts, under the guise of raised prices. Besides, the habit of buying on credit constitutes a veritable servitude for any workman's family which gets caught in its meshes. The word servitude is not exaggerated, for if a man is in debt to his grocer or his baker he cannot complain of the prices, the weights, or the quality of the goods supplied, nor can he go and deal elsewhere; he must perforce accept everything for fear of his account being closed. And if he sees no chance of freeing himself from the debt he gives up hope, breaks up his home, and leaves the locality secretly.

Even for the well-to-do purchasers who always pay up in the end buying on the credit system is a detestable habit, for nothing encourages useless expenditure like the opportunity of being able to buy without money. Traders are well aware of this, and therefore are in favour of the credit system. True, they themselves are often the victims of the habits they have encouraged in their customers. We have often seen milliners, dressmakers, restaurant keepers, obliged to close down their businesses, unable to meet their obligations, even with very rich clients on their books. Large fancy goods warchouses make a rule of cash sales only, but small shops can only hold their customers by offering them the bribe of credit. It is therefore not only in its own interest, but in that of the labouring population also, that the co-operative society should make a rule of salc on a ready cash basis, both as a means of education and of 
emancipating the poor man from this wretched form of dependence.

Gladstone, the illustrious statesman, viewed this as the greatest virtue of the consumers' society. Nevertheless, it is necessary to say that this rule is not always observed and that a large number of societies, even in England, sell on credit, and this number is increasing. ${ }^{5}$ However, the total sums due only represent 1.5 per cent. of the gross sales, so there is no great cause for alarm. Undoubtedly the temptation is great. On the one hand, a feeling of humanity makes it difficult for the society to refuse bread to its necessitous member, and, on the other hand, there is always the hope of fighting the traders by attracting their clients through the same advantages. But it is a bad method of vanquishing an adversary to imitate or borrow his bad qualities; such tactics may be commercial, they are certainly not co-operative. The worst evil is when a co-operative society uses the sale on credit as a means of enticing away the members of a society which sells only for cash. This is self-evident.

If the working population of a locality is really reduced to living from day to day, and has not the ready money to make its purchases, if it is obliged to wait for its fortnight's wage to be able to pay for its food, it would be better to form near the distributive society a loan society, either philanthropic, or preferably a mutual aid society, which could make advances to the necessitous workman. These loans could be made by taking the member's share pass-book as a guarantee, or by accepting the security of one or two of his friends, or even by making the loan a debt of honour, where the mem-

5 This is equally true of the American societies. Many of the societies have even been known to give credit in unlimited amount to nonmembers and to share the surplus with them as well! In bad times, these societies which give credit to many of their members and at the same time are burdened with the expense of a delivery system are exceedingly hard put to it to compete successfully with the cash-andcarry chain stores. 
ber is worthy of confidence. Some societies have tried these systems.

When a society starts on the perilous path of selling on credit it is absolutely essential to impose certain rules. It may limit the credit to a certain sum, generally to the amount of the shares held by the member, which will serve as a guarantee. Or it may only give credit for goods of a durable nature, such as furniture. In this case, selling on credit, or at least payment by instalments, may be justifiable, the ultimate expenditure being greater. We know that one large business house in France has made a specialty of selling furniture on the instalment system, and the abuses of the system are not as great as we are told. They have even rendered a national service by enabling young people to marry and set up a home without having to wait until they have saved enough money to buy furniture. As regards bread, rather than sell it on credit it would be better to give it gratuitously, on the member's fulfiling certain conditions as specified in the rules-when work is interrupted and when unforseen misfortunes occur, \&c. This is what the Belgian societies do; they give quantities of bread, proportionate in their value to the purchases previously made by the member.

We see that in Belgium the society not only refuses credit to its members, but that, on the contrary, it is the members themselves who give credit, by buying counters in advance, whereby they can obtain bread for a week or a fortnight. An excellent way of compelling the workmen to be provident!

\section{(3) Selling to the Public}

The third question which arises à propos of sale is that of deciding whether a society should sell to its members only, or to the general public. There is no doubt that selling to the public is outside the sphere of co-operation. One might even say that it is outside its very definition, because when a society sells to the public it can no longer say that its object 
is "to provide for the needs of its members." Thus, German law, considering that sale to non-members is incompatible with the essential character of co-operation, has prohibited it under severe penalties. (Laws of 1st May, 1889, and 12th August, 1896.) This regulation must be posted up in the societies' shops.

The Rochdale Pioneers sold to the public, but in order to avoid the reproach, which they themselves levelled at the private trader, namely, that of exploiting the public by making profit out of them, they adopted the method of giving the non-members who dealt with their society a bonus or dividend at half the rate of that returned to members, placing the surplus in the reserve fund. This rule is not absolute everywhere. Some societies give the non-member buyers a dividend at quarter rate only. Others, on the contrary, allow them a three-quarter rate. There are even some (at least that of Darwen) which give to non-member purchasers the same dividend as that given to members-an entirely unwarrantable generosity, as we have said above. ${ }^{6}$ Perhaps it may be said: Why do you not give the public the full amount of the dividend on their purchases, or at least a sum equal to that of the members, thereby abolishing all exploitation? But if this were done, the public-enjoying the same advantages as the members without having their responsibilities (shares, administration, \&c.)-would have no inducement to join the society, and thus the aim of cooperation, which is to attract as many members as possible, would be manifestly diverted.

This ingenious Rochdale rule of sale to the non-member with limited participation in the dividends has been adopted by the majority of English consumers' societies. On the Continent there is more diversity. Sale to the public is generally practiced in Russia, Spain, Switzerland, Belgium,

${ }^{B}$ In the United States one-half or one-third of the full savings-return is often given to non-members. In some instances the full return is 
Holland, Italy, and in France, since in the last-named country the co-operative societies have been put on the same footing as the traders in the matter of the imposition of taxes. (See Chapter xiv.) It should be said, however, that in Switzerland socicties are gradually giving up selling to the public. In Italy, the heads of the co-operative movement are trying, on the contrary, to encourage it. In France up to the Act of 1905 co-operative societies were treated differently in the matter of taxation, according as to whether they did or did not sell to the public, only the former societies having to pay for their trade license, the latter being exempt. But, as we shall see later on, they are all now treated similarly-at least, those which have retail stores.

Both in France and in Switzerland this question of sale to the public has been the subject of endless discussions. In France the two opinions are equally balanced. The Cooperative Congress at Limoges in 1907 allowed sale to the general public, but more as a matter of toleration, and under the condition that the surplus arising from sales to the public should not be distributed among the members, but be employed for propaganda, for education, or for any other work of general interest. The system of sale to the public is most generally preferred: First, because it is believed that selling to the non-member is the most efficacious means of propaganda on bchalf of co-operation; secondly,

given. In many societies the return to non-members must remain with the society and is applied toward payment for capital stock. We met one woman recently who serves us here as a fair example of the kind of person with whom Co-operation has to deal in most American cities and towns. Although she had never been a member of the local co-operative, she had come around regularly each year to collcct her savings-return on purchases. This last year the return fell from $4 \%$ to $2 \%$, and she not only refused to trade at the store any longer but used her experience as a talking point to prove that co-operation is worthless. She is now trading regularly at a private store, receiving no return whatever, and appears to be well satisfied. 
because according as it increases the takings of the society so it enables the society to reduce its working expenses, to increase the rapidity of its turnover, and, finally to enlarge its spheres of operation. If it is the ambition of co-operation to take the place of ordinary traders it will have to enter the list by carrying war into the enemy's camp.

But it must be admitted that those co-operaters who are hostile to the system of sale to the public are not without excellent arguments. In the first place they hold it as a point of honour not to be mistaken for traders, and for that reason wish to avoid doing as the latter do. And they believe that the habit of selling to the public would have the result of developing the mercantile spirit in co-operators, and the love of money, to which they are already too much inclined. Many co-operators even fear that selling to the public'kills the co-operative spirit completely and transforms the co-operators into traders.

These apprehensions would, doubtless, be justified if cooperators were in the habit of benefiting themselves by the profits accruing through sales to non-members. This reproach cannot be laid to their charge if they are faithful to the Rochdale rule, and give back to non-members a part of the dividends due to them and place the surplus in the society's reserve fund for the development of the society.* We must not forget, however, that the reserve fund belongs to the members and must return to them in the event of the dissolution of the society, and that, consequently, everything that is put into the reserve fund is to their indireat benefit. ${ }^{7}$ Even such advantages as works of solidarity, bene-

* Author's Note. This system, however, entails a somewhat complicated system of book-kecping, because two separate accounts have to be kept, one for members and one for non-members and an account must be opened for each purchase, even though it be a solitary one.

7 The members of the Co-operative Cafeteria of New York City voted unanimously to accept from their association only such savingsreturns as were due them on actual sales to members. Considerably more than half of the business of this society is with non-members. 
fit clubs, education, recreation, \&c., profit the members in the long run. To do away with all appearance of exploitation of the public it would be better to apply the profits accruing to the socicty fron sales to non-members-or at least the part which is not returned to them-towards scme work of public utility outside the society. But then, there should be a mutual arrangement for this, because if each society were to support some different public institution, such scattered expenditure would not have any appreciable results.

To sum up, selling to the public should be allowed only as a means of attracting members and making the society known to the public, and not as a permanent practice. Every purchaser should be, if not actually a member, at least a candidate for membership. In every place where this principle is understood and applied the sale to nonmembers is a negligible quantity -4 per cent. to 5 per cent. of the total sales in England, 7 per cent. to 8 per cent. in France* In fact, these purchases very soon pass from the category of non-members to that of members. This is even compulsory, for, instead of paying a part of the dividend to non-members (with which they would probably be content and not trouble about becoming members), this part of their bonus is retained in the society and registered to their credit, so that they automatically become members.

Unfortunately, there are societies which, so far from wishing to convert the non-member purchaser into a member, ask nothing better than to leave him outside the participation of dividends, so that the latter may become larger. Such is the

* Author's Note. We say 8 per cent. on the total turnover or sales, that comprises all the societies, even those who do not sell to nonmembers; but if we only take into consideration those which do, then the proportion of sales to the putlie is much higher. According to the investigation made by the Ministry of Labour, the proportion of societies selling to the public is 38 per cent., and the proportion of sales to the public in these societies is 21 per cent. 
case in a certain number of societies in France, and still more so in Spain. This explains a fact which at first sight scems disconcerting. We see, for example, in the Vosges district, a society of seven members which did a retail trade of $£ 1,964$ in 1913 . Is it possible that each member's trade

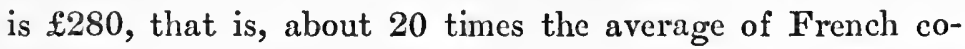
operators? Certainly not, but 95 per cent. of these sales are made to strangers. They may not even come to the shop, but buy second-hand from the members. Such are societies of workmen-traders. At Bordeaux, the co-operative socicties reckon that nearly one-third of their sales are to the general public. At Barcelona, in Spain, there are societies where one sees workmen-members receiving from

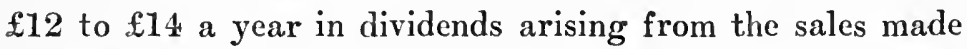
to their non-member comrades, whom they induce to come to their shop as customers. It is somewhat the same system as that of workmen who sub-let a room or a bed to comrades poorer than themselves, and make a profit at their expense.

It may also be said that the conversion of a non-member into a member is hindered, not by the spirit of avarice on the part of the socicty, but by the indifference of the purchaser. In order to combat this grievous inertia of the public, a good number of French societics have created a category intermediate between non-members and members, that of "adherents." These are reckoned as members in all the statistics, although they are not legally so, not having paid for or even subscribed for shares. There is only a minimum entrance fee demanded of them, generally one of $1 \mathrm{~s} .6 \mathrm{~d}$. They cannot participate in the management of the society, and have no place at the meetings; nevertheless, they generally receive the same percentage of bonus as the members. This is a method of attracting those workmen to the society who are not enthusiastic, or who have not means enough to subscribe for a share. This system (which establishes two 
classes of members, superior and inferior), cannot be recommended, because it is anti-democratic and anti-co-operative. There are even some societies where the "adherent" cannot become a member as the number of shares is limited, as, for example, that of the Civil Employees of the Seine. 
Since in accordance with the rules laid down in the preceding chapter, the co-operative society selling at current prices ought to make profits, it remains to be seen what is the best way of using these profits. This is one of the fundamental questions of co-operation. We have already said that the master stroke of genius of the Roclidale Pioneers was the discovery of exactly that method of using profits which has been the chief cause of the success of consumers' co-operation, namely, the division of profits among all the members in proportion to the amount of their individual purchases.*

We must recognize that it is the application of this rule which has ensured the successful development of consumers' societies, since it gives to each member a reward proportionate to his co-operative zeal, to his loyalty to his shop. Besides, it is founded on one of the most certain of economic laws, the law that the success of a business enterprise depends less on its capital than on its customers. It is therefore just that the profits should belong to those who by their acts cnsure the prosperity of the society.

But it must be admitted that the Rochdale co-operators,

* Author's Note. The principle of sale at current price, and consequently of a profit to be gained, was promulgated before the time of the Pioneers at a co-operative congress held during Owen's lifetime, in 1833. But the profits thus to be realized by the soeiety ought to be retained by it and dedicated exclusively to the development of the socicty itself. The original idea was to give the profits back to the members (See Industrial Co-operation, by Miss Catherine Webb.) 
although disciples of Owen, showed themselves to be thorough individualists and made an appeal to personal interests the great motive force of their movement. Still, this rule is none the less a new and wholly revolutionary principle in our economic organization, because it is no small thing, either in fact or in theory, to lay down a proposition that capital has never any right to profits. It is so much the more severe, because capital is deprived thereby of truly enormous profits. (See Chapter Ix.) It is nothing less than the destruction of capital, or at least its reduction to the position of a mere factor in production; it amounts, in fact, to a decision that all of the profit which capital has regarded as its legitimate share should be restored to those from whom it was taken, and that share capital should be reduced to the position of debenture stock, with a rate of interest fixed at the minimum at which its services can be hired; that is to say, that it shall be treated exactly as capital itself has treated labour.

It goes even further than this; it is not merely taking profit from one person and giving it to others. The transfer of profits from the capitalist to the consumer is actually the abolition of profits, because to say that profits shall be returned to those from whom they were taken is obviously abolishing them. This is clearly expressed by the French term which is used to designate these so-called profits. They are never called by that name, but are called bonuses, repayments, or, better still, overcharges (trop perçus). In England they used to be called dividends, but are today called surpluses. ${ }^{1}$

It is a way of saying to the consuming member: "We have charged a little too much, that is to say, more than the fair

1 In the United States the word surplus-saving is taking the place of "profit" and savings-return is coming into use in place of the word "dividend." The word "dividend" is still widely used in England as in the United States and "divi-hunting" is the curse of many societies in both countries. 
price, for various reasons, either to help you to save, or to give you a pleasant surprise, but the surplus we have taken we now return to you; here it is!"

The climination of profits means the establishment of a state of society where everything is sold at cost price, that is to say, at the price which exactly represents the sum of wealth and labour which it has absorbed; that would be nothing less than to realize the dream of all the socialists since Owen, the initiator of co-operation. It may also be said, without paradox, that it would be the realization of the ideal of all the economists of the liberal school, for, did not these aim at a perfect state of free competition which could have no other result than to reduce the rate of profits to zero? In fact, all competition tends to bring the selling price closer to the cost price and consequently to reduce profits. The manufacturers know their business! This law cannot act in the present economic conditions, because a thousand obstacles under the form of legal or actual monopolies obstruct it, but if undor an imaginary régime of absolutely free competition all these obstacles were removed, the sale price and the cost price would be identical. So that, paradoxical as such an assertion appears, it may be said that if co-operation were universal the end which is vainly imagined under free competition would be attained.*

In order to calculate the amount returned to each member, it is necessary, first of all, to know exactly the amount of his purchases. For this purpose, either a special account is

* Author's Note. See the chapter Cooperation ou Compétition in our book Cooperation. M. Walras declares emphatically that, under a régime of open competition the margin of profit is zero. There is, however, this difference between socialists and economists, as far as the abolition of profits is concerned, that the former include interest in this abolition, whereas economists see in interest a necessary eleInent in the cost of production, which should survive the abolition of profit. As for co-operators, they hesitate between these two theories, but the majority are generally in agreement with the economists. (See later, Chapter Ix.) 
opened for each member, or all his purchases are entered in a pass book, which he has to bring each time he goes to the shop and to return at the time when the accounts are closed, or else each purchaser is given a docket on which the total price has been printed. We need not discuss the technical advantages of these different methods.

Once the total purchases are known the bonus remains to be calculated. Generally, the proportion between the gross total of sales and the net profits realized is taken, and this proportion is paid on the purchases of each member. Thus, if a society sold a million pounds' worth of goods and made $£ 150,000$ net profit, or 15 per cent., the member who has bought $£ 100$ worth of goods, has a right to $£ 15$ bonus. But the profits vary considerably according to the different articles sold. There are, for example, some goods, such as sugar, upon which little or no profit is made; others, such as meat, upon which there is often a loss; and others, such as preserves, upon which the profit is high. As a result, the member who only bought the goods which were sold without profit or at a loss would be very much benefited by such a division of dividend.

To avoid this difficulty some socicties make a rule of fixing the sale price of each article at, for example, 20 per cent. above the cost price in order to make the same profit on each article. In these circumstances the prices, being fixed automatically, are sometimes much above and sometimes much below the current local prices, and as a rule unscrupulous members yield to the temptation of buying from the co-operative store only those articles which are sold below current prices, leaving on its hands those which are sold above market rates, because they can buy these cheaper at the ordinary shop.

Is there any need for thus seeking to equalize the advantages which members derive from the division of the bonus? We think not. The apparent injustice is, on the contrary, 
a striking application of the law of solidarity - which ought to govern the societies. In fact, it is generally on articles of luxury that the profits are highest, whilst they are lowest on articles of prime necessity. Thus the poor members benefit from the purchases of the rich, and this is as it should be.

In what form are the bonuses distributed amongst the members? In money, according to the Rochdale rule, which is generally followed. The Belgian societies have put into practice another system, which is that of paying the bonus in the form of dockets which may be exchanged for goods at the co-operative shop. The advantage of this system is that the member cannot go outside the society to its rivals or to the public-house to spend the money made by the society; by this means the turnover of the society is increased each year.

Nevertheless this system is not to be recommended, neither from the economic point of view, because it forces the member to increase his consumption, since he cannot use his bonus except by increasing his expenses, nor from the moral point of view, because it re-introduces for the benefit of the co-operative societies those very acts, such as the practice of shopkeepers who give their clients "discount stamps," which are convertible into goods in their own shops, which have been so strongly blamed in private businesses. It compels the workman to spend all his wages in the social shop, and does not give him the satisfaction of being able to spend a single coin freely. Money implies the liberty of spending; it can no doubt be misused, but like all liberty its use can be learned only by practice and not by a kind of tutelage. A German law of 1896 prohibits co-operative shops, as well as économats and traders, from issuing tickets or counters payable in goods.

The half-yearly dividend makes a very appreciable increase of revenue for a working-class family, and is greatly 
welcomed by the house-keeper. I know very well that those who disparage co-operation, and who mock at its ambitions, say, "What does it give? Taking what it can give, even where co-operation has had its greatest success-in England - the $£ 13$ millions of bonuses (with deduction made for interest, as it should be) divided among three million co-operators, is equal to $\mathfrak{E} 4$. 7s. 6d. per family. That will not change the condition of the working classes. A rise of pay gained by a good trade union organization or by collective bargaining could give as much."

But this $£ 4$. 7s. 6d. is only an average. It is not surprising that the average should be small if one considers: (1) That among the consumers' societies there are many which do not set themselves out to increase their members' incomes, but simply aim at selling at a low price, or have one of the various other aims which we shall consider later; (2) That among the three million co-operators there are many who are only co-operators in name, and, since they never go to the shop, obtain no bonus. It is the nature and honour of free social institutions that they can be useful only to those who wish and know how to use them, and they cannot be asked to give their services to those who do not want them. But, if instead of taking the general average, we find how much increase in income certain members in certain societics can gain, we shall find results which are far from negligible.

Thus, according to an enquiry made a few years ago in Britain, we find in the Perth Society one member receiving $£ 264$ in 26 years, which is equal to $£ 10$ a year, another in

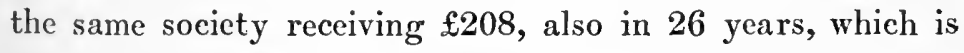
equal to $£ 8$ a year. In the Manchester and Salford Society a member received $£ 360$ in eighteen years, which is $£ 20$ a year. Probably this member was a highly-paid clerk, not an artisan, but that does not affect the question. A recent number of the Co-operative News cites the case of a mem- 
ber of the Newmains (Lanark) Society, who in 26 years received £944. We in France are a long way behind these figures.

The figures for France are not known, as the societies do not state their bonuses, but it must be admitted that in France - for reasons which we shall give later-the bonuses distributed are very much lower; they hardly ever amount to $\mathfrak{f 4}$, and are often less. Still they are benefits to small households, as is proved by the discontent expressed by the members if in any year there should be no bonus. M. Barriol, a statistician, has published some particularly illuminating calculations. They deal with the supplying of a family of co-operators with provisions before the war. This family belonged to a Parisian co-operative society; their total expenditure was £96. At the prices marked in Potin's catalogue the total cost of the articles in this domestic budget would have reached $£ 108$. Therefore, the saving effected by this family amounted to $£ 12$. If we add to this the 5 per cent. dividend distributed by this co-operative society, namely, £4. 16s. (and, if so desired, the 3 per cent. collected for the social work of the society, i. e., 22.17 s. 7d.), we see that there has been a saving to the amount of $£ 19.13 \mathrm{~s} .7 \mathrm{~d}$. realized by this co-operative household. The difference would be still greater if instead of making the comparison with the prices of the large Parisian grocery store we took those of the grocers in the working-class quarters. Of course, it is evident that in this case we are dealing with a very well-paid workman's household, as is proved by the figure of $\mathfrak{£ 9 6}$ in purchases, which must mean an income of at least $\mathfrak{£ 2 0 0}$ in pre-war values.

The amount of extra money divided among the members depends upon somewhat complex conditions:

(1) It obviously depends upon the good management of the society. It is very evident that if the society is badly managed it will suffer the fate of all badly-managed busi- 
nesses, it will not make any profits, and consequently will have nothing to distribute. When a society pays no dividend or a small dividend it may be on principle, as we shall see later; but it may be, and more often is, simply owing to incapacity, bad management, bad accountancy, dishonest employés, undue increase of rumning expenses, and lack of experience in buying, supplemented by the absence of a wholesale society, \&c. (See the chapter on the causes of success and failure of socictics.)

(2) The rate of dividend also depends upon the loyalty of the member in using his co-operative shop. The loyalty of co-operators, above all that of their wives, who, in fact, have entire charge of the purchases of the household, varies greatly. Even in the most active societies there is a large number of members who only deal at rare intervals, either because of their distance from the shop, or from apathy, or, from the commonest of all motives, because their wives prefer to buy things from the "grocer round the corner." *

* Author's Note. According to calculations made by Cernesson as regards all the Parisian societies (Revue des Deux-Mondes, 15th Oetober, 1908), the average purchases per member amounted to $£ 10$. 14s. 4d. We went through these calculations, taking the four most important societies from those belonging to the Federation and of socialist tendeney, and, as we foresaw, we obtained a remarkably higher result£23. 7 s. 2d. (in 1913). Nevertheless, this figure is still much less than it ought to be, because it hardly represents a quarter of the wages of a workman's family in Paris, and the societies in Paris offer the most varied assortment of goods. If the members really did their duty loyally as members, they could double or treble the amount of their purchases. In the "professional" co-operative societies of workers-societies formed of clerks, \&e.-the average purchase per member is considerable, because their incomes are larger, and also because they are more regular in their purchases.

The following table shows the average purchases per member in various countries before the war:-

\begin{tabular}{|c|c|c|}
\hline & $\mathfrak{f}$ & s. \\
\hline England & 29 & 4 \\
\hline Finland $\ldots \ldots \ldots$ & 25 & 4 \\
\hline Denmark ................ & 24 & 0 \\
\hline Switzerland $\quad \ldots \ldots \ldots \ldots \ldots$ & 20 & 17 \\
\hline Germany $\ldots \ldots \ldots \ldots \ldots \ldots$ & 15 & 7 \\
\hline France $\ldots \ldots \ldots \ldots \ldots \ldots$ & 14 & 12 \\
\hline
\end{tabular}




\section{6 CONSUMERS' CO-OPERATIVE SOCIETIES}

There are societies which seek to make loyalty compulsory, by cxcluding any member who has not purchased during the year, or the half year, goods to a certain minimum value. But this rule, although it is statutory, is very seldom applied, because it would have the effect of excluding too many members in each year. ${ }^{2}$ The loyalty of members is a matter of education, not of coercion. To become a member of the Central Council of the new French Federation one must be able to guarantee having made the required minimum amount of purchases at one's own society, that is, if there is a statutory minimum. The Siberian co-operative societics have a different form of compulsion. Any member who does not reach the required minimum of purchases is liable to a finc of £1. In fact, the average purchases per member has, as was natural, risen since 1914 to $£ 41$ in Britain, and $£ 20$ in France, \&c., but if the depreciation of money is taken into account it may be said that the average purchases, measured in quantities rather than values, has fallen.

(3) Further, success is dependent in part upon the capacity of the shop to supply all the needs of its members. If it only supplies bread or groceries it is obvious that the total consumption of the member-however zealous he may be, though he buys up to the maximum of his possible consump-

As these figures are obtained by dividing the amount of sales by the number of members (see Table, page 49) it follows that in the countries where the societies sell to the public the average purchases per member is increased by the sum sold to the public, as the two sums cannot be distinguished. These averages, then, are not strictly comparable. Thus, Germany-where sale to non-members is prohibited - would find herself handicapped, if she had not the advantage that only her most important societies were chosen as examples, those in the Table, page 54 .

2 This is the reason why such a rule is not in practice oftener in the United States. But there are societies which do have this rule embodied in their by-laws. It is not entirely that they wish to make loyalty compulsory (although that element enters in, of course); but they see no reason why any one should be able to invest money in a co-operative society and receive interest on it when they themselves have done nothing to contribute to the success of the business. Such is a modified form of profiteering. 
tion-and therefore his total bonus, will be very limited. If, on the other hand, the co-operative shop sells all possible articles, it is clear that the member, having no temptation to go elsewhere, can spend in it nearly his whole income, and, in consequence of this, gain the benefit of extra income from all the branches of his family budget.

It is partly for this reason that in Britain the average of purchases per member is far higher than that of any other country, while we know that in France nearly one-half of the societies only sell bread while the other half only sell groceries.

(4) The absence of competition is another factor. If there is no shop other than the co-operative society in the locality-as is sometimes the case where co-operative societies are attached to large works or mines-it is very clear that the worker will buy there everything he needs. Thus, in the Society of Anzin (a great French colliery) the average of members' purchases is more than double the general average, being about $£ 32$, bringing back $\mathfrak{f 6}$ in bonuses, or the equivalent of a month's pay.

(5) It also depends partly on the prices at which goods are sold, for it is obvious that, other things being equal, the rate of the bonus to be distributed will depend upon sale prices. The question of the price at which goods should be sold has been raised in all the Co-operative Congresses.

The lowest price, that is to say, the cost price, is charged at the two extremities of the scale: First, in those societies whose members, coming from the very poorest classes, have first to think of eating before they can think of saving or bonuses, and, secondly, in the societies of professional men who have to be economical, but who do not bother about small bonuses.

High prices, that is to say, prices above prices current in outside establishments, are favoured in districts which are strongly co-operative, and which can equally well be socialist or bourgeois. The difference between the two types of 
society lies in the object of employment of the profit obtained by increasing prices. The object of the bourgeois societies is to give each member the maximum individual return, and they pride themselves in distributing 20 per cent., or, even like some British societies, 25 per cent. in bonuses. In the socialist societies, such as the Belgian co-operative societies, the object is to provide money for works of social solidarity, and even to contribute financial support to their political party without disdaining, as one may well believe, individual sharing. Still, there is today a tendency to re-act against high prices, and to be satisfied with moderate dividends. High prices make co-operation inaccessible to the poorest classes, and often have the effect of creating unfortunate rivalries between co-operative societies in the same town, since each one tries to attract members to itself through their appetites for a larger dividend, and finally pervert the co-operative spirit by bringing in the spirit of gain, and thus work altogether against co-operative education.

In England, the question of what is understood by "a good dividend," and by what standard it should be measured, is often debated. It must be answered that a good dividend is one which is obtained solely by good management, and on the contrary, that a dividend, however high it may be, is bad if it is only obtained by one of the four following means -raising the prices above current prices, lowering wages below the trades union level, elimination of contributions to works of general utility, or the abolition or great reduction of the part which ought to be set aside for reserve and depreciations. $^{3}$ In Britain the average of dividends is $\mathbf{1 3 . 5}$ per cent., but according to general opinion this is too high. In Switzerland the average is only 7 per cent. In France

3 The two first-named of these evil practices by which liigh surpluses are realized are little known to American co-operation. The two last-named evils are all too common. But in any event, returns seldom exceed 7 or 8 per cent. here; and more often they are as low as from 2 to 5 per cent. 
it generally does not reach 5 per cent. There is, however, a society at St. Remy sur Avre, in Normandy, which distributes 15 per cent., but it is composed almost exclusively of farmers.

What should the member do with this addition to his income? It is possible that he spends it, and in this case he draws from it no advantage other than a gratuitous increase in his consumption-one can name societies in Paris where the bonus, as soon as received, has been used for a little "spree,"-but if it be a fairly round sum-some bank notes, or at least a few picces of gold-and if the co-operative spirit is sufficiently developed, it is Iikely that this sum will not be spent in the public-house, but will be used for some extraordinary expense, such as the purchase of furniture-this is the commonest form among English co-operators, who are proud of their homes-the payment of some old debt, the payment of the doctor's bill in case of sickness, the marriage of children, \&c. "Extraordinary expenses" come into every life, however simple, just as into public finance, and in order to meet these a budget of extraordinary receipts should be kept, as well as one for ordinary expenses. Since the workman generally does not have any extraordinary receipts, his only resource is to run into debt. Co-operation brings him this extraordinary income in the form of the bonus. When visiting the enormous warehouses of the Co-operative Wholesale Society in Manchester we were surprised to see relatively elegant and expensive furniture on sale, such as wardrobes with mirrors, cabinet dressing-tables, baths with gas heaters, and even pianos. Being astonished that such furniture could be within the reach of the income of a working-man, we were told that these things were bought at the time of the distribution of dividends. Of course, they are often bought by principal employés and other well-paid cooperators.

If he has the good fortune not to have to meet any extraor- 
dinary expenses he can add this extra money to his savings; he finds it a ready means of saving, and this, therefore, is an important object of co-operation, and one which economists praise above all; and for a long time in France, as in England, they have recommended that no other aim should be sought. This is what prudent co-operators in Britain do. Among those we mentioned (page 83) the one who received $\mathfrak{f 2 6 4}$ left $\mathfrak{f 8 8}$ in the society, and he who had received $\mathfrak{f 3 6 0}$ left $\mathfrak{f} 60$ in the society. The capital which is left in the society in the form of loans or share subscriptions is estimated to be about one-third of the annual profits. The gross total of these accumulated savings is now nearly $£ 80,000,000$.

It should be remarked that this saving has the wonderful property that it has not been made at the cost of privation. It is the only means of saving of which this can be said. Economists consider saving under the word abstinence, and, in fact, it seems a contradiction in terms to say one can save without depriving oneself of anything. Such is, however, the squaring of the circle which co-operation has achicved, in the neatest possible manner, by that solution which is called "saving by spending." It should be noted that this saving is not only easy, but that it becomes compulsory and even automatic cach time the bonus, instead of being paid in cash to the member, is retained and credited to his account until a certain sum is reached. That is the rule followed in nearly every co-operative society where the members have paid only one-tenth of the value of their shares on entering, or where they have merely paid an entrance fce. Their share of the bonus is retained from halfyear to half-year until it has reached a sum equal to the value of the share subscribed for, or to be subscribed for. This method of enforced thrift is most successful in the Schulze-Delitzsch co-operative credit societies and the English and American co-operative building societies, because 
the value of the shares is usually fixed rather high (£20 to $\mathfrak{f 4 0}$ ) precisely with this intention. Once a member has got into the habit of seeing his bonus kept in the common fund he very easily forms the habit of leaving it there of his own free will, even after his shares are fully paid up and the retention of the bonus is no longer compulsory. ${ }^{4}$ In this way the consumers' society acts as a savings bank.

One of the methods of saving which is most appreciated by co-operators is that of acquiring a house by annual payment. We shall discuss this later on.

There is another form of saving which is particularly needed by workers, that is insurance against sickness, old age, and unemployment; I do not say insurance against accidents, because in most countries the employer is liable for compensation in such cases. The worker who wishes to guard against these risks has to join either a mutual aid society or a trade union, if not both at the same time, and to pay to each subscriptions which form a fairly heavy tax on the income of the worker. Well! the bonus gained from the consumer's' society will provide money enough to meet such misfortunes, for, by a happy compensation, while other forms of association cost money, this one brings it in. M. Cheysson has calculated that the premium to be paid for insurance against the five risks to which working-class families are exposed-sickness, incapacity, old age, unemployment, prema-

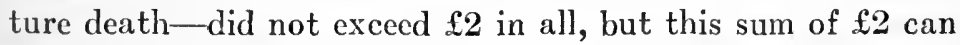
easily be obtained by affiliation to a consumers' society, even in France; it only represents a bonus of 5 per cent. on a total purchase of $£ 40$. M. Cheysson set limself to advocate this means of employing bonuses, as he saw in it the saving

4 The best societies in the United States encourage this practice on the part of the members. Many a society has found that it could increase its amount of share capital per member in no other way. Such rc-investment of savings-returns of ten goes either toward the purchase of shares for other individuals in the member's family or into the loan capital fund. 
of mutual benefit societies. We do not object to this, provided that it is left to the co-operator himself to use his bonus in this way ; but if it is the co-operative society which, owing to lack of confidence in the spirit of foresight among its members, wishes to pay the bonuses to mutual aid societies directly, then we should have serious objections to the system, because in that case co-operative societies would only be cows to be milked by mutual aid societies! It is the duty of co-operation to kecp its resources for its own ends and not to serve as the instrument of other organizations.

It is also curious to note that on this point economists of the "saving" school meet socialists, who also condemn the division of bonuses among individuals, in theory at least, and wish to consecrate them to social ends. (Sec the last chapter, "Co-operation and Socialism.")

When a society divides the whole of its profits, except that portion which is by law devoted to a reserve, among its members, one may think that it pays too much attention to the interests of the individual and is not unlike a purely capitalist society. One expects that a co-operative society should give some attention to a loftier and more social purpose. 'The Rochdale Pioneers understood this well, as is testified by their excellent act in devoting by their rules $21 / 2$ per cent. of their bonus to education. If all the English socicties had conformed to this rule it would have formed a fund for popular instruction which would be far from negligible, because, on a total of $£ 13,200,000$ of profits, this tax would have realized more than $£ 320,000$ a year. It is true that when the Pioneers established their budget for educational purposes, public education did not exist in England; it was only given in private establishments, principally religious. Nowadays, funds for education are less urgent, as it is provided by the State. But the idea of the Pioneers was not merely that of general education, but one of co-operative instruction also: they wished to mould new generations of 
co-operators. Now this necessity is more urgent than ever, in England and elsewhere.

In reality, no English society, as far as we know, has had the courage to put into force the Pioneers' rate, not even the Society called the Rochdale Pioneers! The total sum devoted to education by British co-operators does not reach $£ 120,000$ or less than 1 per cent. In all their Congresses, and in their papers, British co-operators complain of the small proportion of their funds which societies devote to education, which proportion, instead of growing, is diminishing. ${ }^{5}$ One of them has said that the dividend among the members ought not to exceed 6 or 7 per cent., and that all the rest (that is, about an equal part, as the average rate of dividend is 13.5 per cent.) ought to go to the education fund. ${ }^{6}$ Out of nearly $£ 80,000$ profits in 1912 they only set aside $£ 800$ (i. e., 1 per 1,000 ) and $£ 240$ for various undertakings, and distributed all the balance among the members, which was a proportion of from 16 to 17 per cent. on their purchases. Leeds is one of the societies which contributes most largely to education (more than $£ 2,000$ ). Of course, it is the largest society of all; but perhaps it is because it spends so much on education that it has become so strong. ${ }^{7}$ "Education," said Holyoake, "is the basis of all our progress." Still, English societies do a great deal compared with those of other countries, and notably of France, where the education grant was zero in almost all the societies.*

5 According to Professor Hall of the Co-operative Union, this is no longer the case.

6 Professor Hall tells us that the Rochdale Pioneers' Society reduced their grant for cducation purposes from $2 \frac{1}{2} \%$ to $1 \frac{1}{4} \%$ in 1904 . Out of 802 societies making grants for educational purposes in 1914, 77 made rcgular grants, based on surplus-savings, of $2 \frac{1}{2} \%$ or more.

* Author's Note. However, thanks to the efforts of the Féderation Nationale Française, the co-operative societies have lately made a grant of Fr. 10,000 to create a Chair of Co-operation at the College de France.

7 Most of the successful societies in the United States do make grants to educational work. Even where the directors are not interested in education for its own sake, they do nevertheless learn before long that 
Co-operative education begins among the children, but it also concerns itself with adults. It has for its object special co-operative education-organization, history, services rendered-and also general instruction; to make good co-operators one must first make men.* Prize competitions are organized among the children, and the best compositions are published in the co-operative papers. Educational committees are formed by the societies, or by the Co-operative Union, and scholarships are given enabling members to attend "summer meetings" at Oxford, Cambridge, or Edinburgh ( $£ 5$ to $\mathfrak{f 6}$ for a stay of a fortnight), including a series of ten or twelve lectures on a given subject, or even scholarships tenable at one of the colleges of the University. But these scholarships do not give great satisfaction, since they have for their result the creation of "bourgeois" out of a few young workmen; it would be preferable to attempt to found a college specially for the sons of co-operators. There are also numerous conferences, and, it goes without saying, libraries, which are the more useful in that books are very expensive in England.

It is true that recreation-the border line between which and education is not easily defined-absorbs rather too large a part-it is said more than a third-or the education fund, notably in the form of teas, picnics, concerts, excursions, 8c. But these very expenses themselves contribute to develop

competitive conditions demand it. Where, as it so often happens, there can be neither lowering of prices below the current rates nor substantial saving-returns at the end of the quarter, what other method is there of holding the loyalty of the membership?

* Author's Note. "We must not reduce edueation merely to teaching the history and principles of co-operation. It would be a narrow and selfish point of view to say that the money spent on education must be employed solely for the development of co-operation and to make good co-operators. . . . It is necessary that our members become honourable and useful men and women, and then we shall have no need to seek special agents for our defence in public bodies." (Speech of Mr. Taylor, member of the Leeds Society's Educational Committee, Co-operative Neros, 21st October, 1899.) 
a good feeling of brotherhood among the members and help to make co-operative societies attractive to the women and the children, who will be the co-operators of tomorrow. ${ }^{8}$

As to the expenditure on solidarity-the English do not fear to say charity-it appears as a not much less considerable amount in the budget of British co-operation ( $£ 96,000)$, although other institutions, such as friendly societies or trade unions, are more specially charged with this expenditure. One should mention the fine convalescent home established by the English Wholesale Society on its estate at Roden. The expenditure on "solidarity," on the other hand, is a considerable item in the balance sheets of the big French societies. A good proportion of the profits is devoted to it. The Union des Coopératives of Paris gives $£ 3,000$ per annum to works of solidarity.

In France the co-operative federation has established an education committee, "groups of pupils," and circles, as far as possible one for each society, which have the charge of keeping the "sacred fire" burning. (There are only about thirty at present.) A few societies have established libraries, and sometimes halls, theatres, conference rooms, consultation rooms, dispensaries and gymnasiums, and such societies are called Maisons du Peuple (People's Palaces).* At the time of the great movement for

8 Most of the educational work in American societies is still very largely propaganda for the local organization. But there is much recreational work also. And during the past five or six years there has sprung up a genuine education movement. Most of this is due, of course, to the activities of The Co-operative League. During the season of 1921-22 many of the labour colleges throughout the country gave courses of instruction in Co-operation, and in a few instances local co-operatives are making financial contributions to this work.

* Author's Note. Co-operative societies in France willingly subsidize the choral societies or the musicians whom they engage for their festivals.

A magnificent collection of photographic views for lantern slides (more than 1,000 views of many countries) was made by M. Fabre, one of the founders of the School of Nimes, and was put by him at the service of lecturcrs. 


\section{6}

the Popular Universities a few societies made them grants, but the results which some people expected from this alliance of the two movements have not been realized. In Spain, curious to relate, consumers' societies, although little developed, have done much to establish schools for children-which are remarkably well kept up-and thus to supply the deficiency of secular education in that country much as was done in England at the time of the Pioneers.

In the Belgian societies education has an important place; it is not that a large part of the bonuses is devoted to it, but it is a general influence exercised over the lives of the members by means of meetings, newspapers, conferences, excursions for the members' children - with entertainment in foreign socialist centres, \&c.-and also by the anti-drink propaganda, which is one of the most interesting features of Belgian co-operation. Brandy or distilled liquors are not sold in the Belgian co-operative societies. Unfortunatcly one cannot say the same for those of France; they have not the same courage. They give as an excuse that if they stopped the sale of alcohol drinking would be in no way reduced, but their members would go to buy dearer and worse drink at public-houses, and this would be worse both for their health and their purses; possibly they would even be lost to the society. Possibly, but if so, so much the worse for them, for to subordinate its moral and educative action to its commercial instinct is to degrade and to kill the co-operative movement.

The Congresses of the Union Coopcrative-notably that of Limoges in 1906-liave on various occasions passed the resolution:-

"That co-operative societies and federations should do all in their power to suppress the sale of alcohol;

"That drinking places where alcohol is sold should be suppressed ; 
"That, acting on the resolution of M. de Boyve on cooperative education (a resolution adopted by our Congress), the educational committees make it one of their first cares to explain to co-operators the reasons for the prohibition of alcohol."

Unfortunately the decisions of these Congresses have no effective sanction.

In Hungary, it appears that brandy is one of the chief articles of sale in co-operative stores; and this is what helps them to fight against the competition of Jewish traders! However, they only sell it by the litre and for ready money, which to some extent may be a deterrent to drunkards.

Among the means of education for co-operators, newspapers specially published by co-operative societies must be placed in the first rank. One may even say that the development of the co-operative movement in a country depends in part on the number of subseribers to its publications. In England are found the Co-operative Neres, a weekly paper with a circulation of 125,000 , and the smaller monthly paper, The Wheatsheaf, with one of 593,000. Switzerland does better still, since this little country has 182,000 subscribers to its principal co-operative paper. There, it should be mentioned, all co-operators are automatically made subseribers by their respective societies, and the price of their subscription is deducted from their bonuses.

In France we are far behind these figures. The Action Coopérative, the organ of the Fédération Nationale, does not yet sell 20,000 copies, and barely pays its expenses. There is also a monthly paper, L'Emancipation, ${ }^{9}$ founded by our friend de Boyve in 1885, organ of the School of Nîmes, of

- In the United States there are a few independent co-operative papers with a small circulation, such as those published by the Central States Co-operative Wholesale, the Co-operative Central Fxchange, and the farners' papers which are primarily interested in the marketing problems but which also devote considerable space to consumers' co- 
which we are now the editor, but this is not exclusively cooperative.

Co-operative education, to have any effect, ought to be made available to women, not only for the general reason that it is they who educate the men, but also for the special reason that women have naturally little sympathy with cooperation, although co-operation cannot live without them. There are hardly ever any bachelors among the members of co-operative societies, as they nearly all live in boarding houses. It is therefore necessary to convert the women; it is they who run the household, who make the purchases, who carry the market baskets. As has been stated with much insight, the woman with her basket is as much one of the great types of working humanity as the ploughman with his plough, or the smith with his hammer. But she generally prefers the shop round the corner to the co-operative shop, not only because it is nearer-a matter of no small importance to the tired housekeeper or one who has little free time between her work-but also because she finds there more attention and sometimes small personal discounts which the co-operative system does not permit.

In 1883 the English formed a Co-operative League for Women-now the Women's Co-operative Guild-which has 44,000 members, holds annual congresses, and has a special page in the Co-operative Neres. The Guild devotes itself to active propaganda, above all, to the fight against mercantilist and individualist tendencies inside the movement, and strives to make it easier for the poor to become co-operators. It also claims that women should have a larger part in the management of societies. In Holland and in Hungary similar

operation. The Co-operative League publishes three monthly periodicals:- the magazine Co-operation, the four-page popular paper Home Co-operator, and a four-page sheet in which the last three pages are given to syndicated matter and the first page is left blank to be used by the local society for local matter. 
leagues have been formed, and not without success, but an attempt made in France a few years ago, under the auspices of the then Co-operative Union, was a failure. ${ }^{10}$

10 In many of the American societies the Women's Guild is now playing a vital part in the strengthening of the movement locally. Some societies have actually been saved from bankruptcy by valiant action of the women at the last moment. Today many new societies are rapidly coming to the realization that active participation by the women in the educational as well as the business side of the movement is a vital necessity. 
Co-operative societies are like miniature republics, and one of their first principles is the equality of members. To ensure this equality, it is the rule that each member, no matter how many shares he possesses, has one vote only. "One man one vote" is the principle of universal suffrage. This is very different from the system in operation in all capitalist companies, in which each shareholder has a number of votes more or less proportionate to the number of his shares, and in which, indecd, even eligibility for executive functions is often reserved for very large sharcholders.* 1

Thus, capital, after having been deprived of its right to the profits, is almost deprived of its right of control. If we were to push the application of this principle to its logical conclusion we should only grant the privilege of voting to purchasing members, and give them a number of votes proportionate to the amount of their trade. But the law does not allow this. A society of shareholders can only be governed by the shareholders as such.

* Author's Note. French law permits the limitation of one vote per shareholder at ordinary meetings, but at special meetings, held with the object of altering the rules, according to a recent law (see later, Chnpter XIV) each member has the right to as many votes as shares held by him. The aim of this measure is to protect the large shareholders against a possible coalition of small ones. This may be reasonable in large capitalist companies, but obviously it is quite antagonistic to the co-operative principle.

1 Of the many fraudulent co-opcrative enterprises in the United States, the commonest characteristic is this limitation of control to the few "elect." 
The equality of members is further shown in the fact that the later comers into the society join under the same conditions and enjoy the same rights as the first member; they even pay the same sum as share subscription. How very different is the position in ordinary joint-stock companies, where any one wishing to become a sharcholder must buy a share, i. e., get one transferred to him by an old shareholder, and if the company is in a flourishing condition he will have to pay a much higher price than the original subscription paid, perhaps ten times as much! This is because in ordinary joint-stock companies the number of shares is limited whereas in co-operative societies the number is unlimited, and the share register is always open. The law which ensures that a co-operative society shall always be open to new members is not, however, incompatible with rules making special conditions obligatory on members, such as that of belonging to a certain trade.

Co-operative societies which only admit members of the same trade or profession are fairly numerous. Thus, there are societies of railway employés, of petty officials, of officers or workmen from the same factory, for example, the societies of miners of Anzin, or the workmen of Creusot, \&c.

Co-operative societies reserved for certain classes have their advantages and disadvantages.

The advantages are that the spirit of solidarity-the "esprit de corps"-is much more strongly developed among persons of the same trade than among persons of varied occupations. These societies generally become very strong and stable; they are well under the control of their directors. This is the reason for the success in every country of tho large consumer's' societies of civil servants, or members of the military and naval services. In London, the two societies which bear the names the Civil Service Stores and the Army and Navy Stores; in Rome, the Unione Militare; in Paris the Socićté des Employés Civils de Paris, \&c. (the 
Society of Civil Servants of Paris and the Department of the Seine), are in the first rank of their respective countries, both in membership and amount of trade.

The co-operative societies of railway employés are becoming more and more numerous in every country, and tend rather to take the place of patronal institutions created by the companies. In France, this has already been done by the companies of the P. L. M. and the East. It will probably be the same with other companies still working on the "économat system," because the law of March 21st, 1910, which abolished the économats for fear of the truck system, making an exception for them in the case of railway companies, has attached certain very inconvenient conditions to the working of économats, notably that every five years the question of the continuation of the économat must be submitted to a referendum of the company's employés.

There are also very prosperous co-operative societies of officers in London, Berlin, Rome, and Petrograd. In France there was one which at first succeeded admirably, but which has since failed, and is now chiefly a club. These societies must not be confused with the military co-operative societies, with which we shall deal further on, which are started for soldiers only, and which cannot be classed as "professional."

The disadvantage is that these societies generally stand aloof from the co-operative movement proper, because, visualizing only economy of distribution, they are not interested in any of the social ends of co-operation and are therefore liable to degenerate into mere commercial enterprises. This, however, does not prevent them from rendering very real service to the class of people for whom they are intended.

Socialists look askance at these consumers' societies of special classes of officials or workers, especially where they consist of workmen or clerks employed by the same man, or the same company: in this case they liken them to disguised économats, and accuse them of being "yellow"-a most un- 
just imputation, if by it they mean that these societies are subservient to the employer or the company as, on the contrary, they are often centres of opposition. And even though it may be true that these societies are of ten disposed to sacrifice the general interests of co-operation to their corporate interests, the same may be said of the socialist cooperative societies, which only admit workmen, sometimes only members of trade unions, and sometimes only workmen who belong to the socialist party. This also applies to those societies which only admit those of some one religious faith. These "red" or "black" associations are open to the same reproach that they level at the "yellow" ones, namely, that of working solely for the benefit of one party, Church, or class, to the exclusion of those who are not of their party, Church, or class. By so doing they belie the character of consumers' co-operation-which, being universal by its very definition, demands from its adherents no other condition than that of being consumers-and by bringing divisions into the co-operative movement, weaken its strength. But we shall return to this question when we are dealing with socialist co-operation.

It is better, then, to avoid co-operative societies of special classes as much as possible, though there are sometimes circumstances in which they become necessary. When it is a question of workshops or mines lying far outside the towns it is necessary to form co-operative societies among workmen of the same factory, there being no other possible members in the district. And as regards railway employés, as the companics allow them special advantages for transport of their provisions-which would not be granted to ordinary traders-it would naturally be impossible for these societies to open their ranks to outsiders. ${ }^{2}$

2 Almost all of the so-called "railrond men's" societies in the United States are open to all. 'They have been started by nembers of the rallroad brotlerhoods but from the beginning they grant full member- 


\section{CONSUMERS' CO-OPERATIVE SOCIE'TIES}

Of course, freedom of entrance should also carry with it freedom of withdrawal, and this is the general rule, although it is not always easy to apply it in practice.

If a member's liberty to withdraw depends-as in the case of joint-stock companies-on the selling of his share, in other words, on his finding a purchaser, this liberty is greatly limited, because shares in co-operative societies have not the large market possessed by shares of the Bank of France, or large industrial companies; it may be rather dificult therefore to find some one willing to purchase a share or shares. This difficulty is further increased if the society reserves the right, as many societies do, to approve or disapprove of the transferee. At the same time it is obvious that this right ought to be reserved, because it would not always be advisable to admit the first comer to replace a retiring member; co-operative societies are associations of persons as distinct from joint-stock companies, which are merely associations of capital. The most liberal system would be to grant the right of free resignation to the member and to refund him his share money on his resignation. But here the society would expose itself to great dangers, as it would only be necessary for discontented members-and there are always such-to organize a plot simultaneously to claim the repayment of their shares to embarrass the society very seriously, perhaps to bring about its ruin. In order to avert this danger, or at least to render it less grave, the society should reserve to itself the right to delay repayment for a period, on the lines of the "safeguard" clause of the Savings Banks. Very often the rules only permit repayment after the death of the member, or on his leaving the town; indeed, the changing of residence ought to be a sufficient reason, in large towns at least.

ship privileges to all other consumers. We do have other groups, however, which make their societies exclusive. This feature is very common to societies among municipal employés, post office employés, and employés of certain large corporations. 
In principle, therefore, the member is free to join or to leave the society. But has the society the right to expel the member, if his presence should be deemed prejudicial to the interests of the society? Yes, in principle, and this right is provided for in the rules of the majority of societies. However, a recent law (1913) has placed a serious obstacle in the way of the exercising of this right, by exacting as a condition of this expulsion the calling of a special general meeting under conditions rigorously imposed by law (see later, Chapter XIII), that is to say, at least threequarters of the shares must be represented, and the decision must be passed by a majority of two-thirds of the votes. This is equivalent in large societies to a prohibition of expulsion. Probably when passing this protective measure for members the legislator was not thinking of co-operative societies; he does not mention them. A revision of this law seens to be necessary.

There is also the much discussed question as to whether a co-operative society should be open to all the nembers of a family, or to one member only. As a matter of fact there is generally only one person in a household who becomes a member of the consumers' society - the husband, although it is really the wife who does all the buying. As the purchases are made for the whole household it seems unnecessary for the other members of the family to join the society. They would have to pay the necessary sum to become shareholders, while neither they nor the society would gain anything-at least in turnover-because the store would not gain more custom thereby.

But it may be said that it is advisable for other members of the family-particularly the women-to become shareholders, in order that they may be able to take part in the general meetings and to use their influence in the administration of the society. Women are at present more or less excluded, owing to the fact that they are scarcely ever mem- 


\section{CONSUMERS' CO-OPERATIVE SOCIETIES}

bers. For this reason the Women's Co-operative Guild urgently presses for free admission of all the members of the family, for what English co-operators call open membership. Moreover, being a member has unquestionable value for young men and women, from the educational standpoint at least, and it assures the recruiting of new generations.

The experiences of several large societies which have adopted the principle of open membership seem to demonstrate that this system has the effect of materially increasing the amount of trade done by each family, contrary to what we might have expected. This may be due to a more constant frequenting of the shop by all the various members of the family, and a more active sense of social duty, once they have acquired the title of member.

Finally, this system has the advantage of increasing the proportion of the subscribed capital as compared with the amount of sales, as the family which was formerly content to have one share only now subscribes for several; we shall see in the following chapter that this increase of capital is highly desirable. ${ }^{3}$

3 Most of the Societies in the United States permit more than one member of the family to join. Usually, however, considerable urging is required before large numbers of women avail themselves of the opportunity. 


\section{(1) The Formation of Capital}

The capital of co-operative societies is formed, first of all, as in all other forms of association, by the subscriptions of those who become members, that is to say by the subscriptions for shares. The French law of 1867 , in order to make these payments possible for every purse, reduced the amount of a share in a co-operative society to $\mathfrak{f l}$, and by a recent law the maximum is fixed at $\mathfrak{f}$, though for ordinary

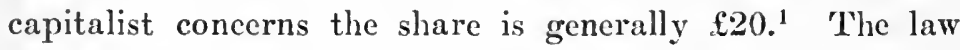
also allows societies to be legally constituted on payment of one-tenth of the share, that is to say, the very small sum of 2s. per member. In England the slare is $\mathfrak{f 1}$ for both societies and companies. It was therefore not necessary to have a special law in favour of co-operative societies.

This is very little. Fortunately, consumers' societies, by the special nature of their business, do not require a large capital, for the reason that by their sales the capital renews itsclf rapidly, and even daily, as in bakers' shops, so that a small capital is enough for a large business. This is the

1 A few states in the United States have laws governing the value of a share and limiting the number of shares to a member of a cooperative. Thus New York State sets a share at $\$ 5$ and permits no individual to hold more than 1000 shares. Generally, however, the local society is free to determine what value it wishes to place on a share and how many it will permit to a single member. There are societies which permit full membership privileges to the owner of one \$5 share, and there are others which ask of each memher as high as $\$ 50$ or $\$ 100$. Very few can get along well unless they receive at least $\$ 20$ or $\$ 25$. 
principal reason for the success of consumers' co-operative societies as against producers' societies, from the point of view of ease of formation and speed of development.

Consumers' societies have been started and have succeeded without any original capital except a small entrance fee. As they buy their goods on credit from the wholesalers and sell them for cash to their members, they can start without money, except that necessary for their modest equipment. ${ }^{2}$ Thus the Bâle Society, which is one of the strongest in Europe (37,000 members, and a turnover of $£ 1,080,000$ ), started without capital, and an entrance fee of only 2s. $6 \mathrm{~d}$. In Belgium, the law does not require any subscribed capital. The Vooruit only requires an entrance fee of $10 \mathrm{~d}$., and $21 / 2 \mathrm{~d}$. for a pass book. These societies obtain sufficient working capital by selling tokens to their members, which serve as payment for bread and other goods. In Germany, the law permits the payment of one share of 1 s. only but in practice the share is $30 \mathrm{~s}$.

Nevertheless, the capital accumulated under such conditions would be insufficient if the capital of consumers' societies were not endowed with the remarkable virtue of increasing automatically by the progressive additions of the dividends which the members often leave, either wholly or in part, in the hands of the society. Members are always asked to do this, and even compelled to do so when they have only

2 We know of very few societies in the United States capable of starting this way at the present time. Even the poorest of co-operators would advise that the group which could not raise any capital through the regular channels of assessment upon each member had better not attempt to organize at all.

Yet there are one or two exceptions to this rule. A society which was organized in Reading, Pa., in 1914 and began business with a capital of a bag of cornmeal, in 1921 had resources of $\$ 18,000$. And a co-operative restaurant in Brooklyn was opened in 1910 without one cent of capital stock paid in, conducting its initial operations on $\$ 200$ of borrowed capital. At the end of 1921 this Society had assets of $\$ 13,000$, although not a cent of capital had ever been contributed by the membership. 
paid up a tenth or other fraction of their share. Their dividends are retained by the socicty until the share is "freed," as it is called, that is to say fully paid up.

Not only do a great number of members leave their dividends on deposit with the society, but some bring to it their savings, as to a savings bank, either on current deposit or on deposit for several years.

If the capital of the British co-operative societies had been built up by the subscriptions for shares at one share per member only, that would only make a total capital for the 4 million co-operators of 4 million pounds, but the capital actually raised in 1920 was 76 millions.*

Thus the capital of societies is fed from three sources: $(a)$ Shares subscribed on entrance; (b) dividends left on deposit or converted into shares; (c) loans from members. Of these three sources the first is the least important; the second brings in the most money, especially in England; in Switzerland, as we shall see, the third is the most important. Morcover, consumers' co-operative societies do not seck large amounts of capital, on the contrary, they are opposed to them. Many socicties, by their rules, limit the number of shares which any member can hold, generally to five, following the example of the Rochdale Pionecrs. ${ }^{3}$ In

* Author's Note. In this figure is included the figures for the two wholesale societies (almost $£ 8,000,000$ ). The capital of the retail societies was $£ 48,240,000$ in 1914 , made up as follows:-

$$
\begin{array}{lllllll}
\text { Share capital } & \ldots & \ldots & \ldots & \ldots & \ldots & £ 39,920,000 \\
\text { L.oan capital } & \ldots & \ldots & \ldots & \ldots & \ldots & £ 5,400,000 \\
\text { Reserve fund } & \ldots & \ldots & \ldots & \ldots & \ldots & £ 2,920,000
\end{array}
$$

In 1920 the share capital reached $£ 76,000,000$ and loan capital $\mathfrak{1 1 0 , -}$ 000,000 . The increase over 1914 is not in proportion to the increase in turnover.

The same miracle of the multiplication of pennies is realized by the individual members also. Thus, the example of a member of the Lanark Society is quoted, who, having subseribed for a few shares, left all profits with the society, and found himself after 36 years the possessor of £9t-4.

${ }^{3}$ Professor Hall is authority for the following statement:- 
Austria the rules only allow one share per member, and the share is only of the value of $8 \mathrm{~s}$. 4d. In England, the law itself fixes a limit, though it is fairly high ( $£ 200)$, that is 200 shares per member. In France there is no legal limit to the amount of capital a member may own-even in co-operative societies. The law once limited the total capital of a society

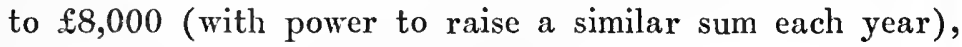
but this restriction no longer exists.

What is the reason for this unusual mistrust of capital? It is explainable on three grounds:-

(a) First, since the very spirit of the co-operative movement is anti-capitalist, and since it seeks to destroy the domination of capital, it would seem hardly wise to open the door and let capital install itself as a master of the society. And if some member-a bourgeois-owned a large number of shares, there would be a fear that he would gain undue influence in spite of the rule which limits the votes to one vote per member; it would be enough if he threatened to leave and to withdraw his capital.

(b) Secondly, because the capital of co-operative societies, being built up in the ways we have just indicated, constitutes a danger as much as an advantage to the society. In fact, all of the capital which comes from the dividends left on deposit is repayable on demand at the wish of the depositor. And the share capital itself has this difference from that of ordinary capitalist enterprises-that it is withdrawable in case the member leaves the society. This is a very dangerous financial position, and one which an ordinary business cannot accept without risk of bank-

"The rules of the Rochdale Pioneers' Society in 1854 limited the holding of any one member to fifty shares. It is not known when the limit was extended, but from 1878, if not earlier, the rules of the society permitted a member to hold one hundred shares. This rule continued to operate until 1912, when the rules of the society were again revised. There is now no limit to the number of shares a member may hold other than that set by Act of Parliament." 
ruptcy.* The co-operative societies can do so, thanks to the spirit of solidarity among the members, who are not ordinary customers and who do not wish to injure the society of which they are themselves a part. The late war furnished in every country an admirable example of this loyalty. At the very moment when the ordinary banks and savings banks were besieged by a rush of their depositors, the consumers' societies generally succeeded in warding off or checking quickly all panic among their members. In England, in the course of one year (1915) co-operative capital-contrary to all anticipations-increased by more than $\mathfrak{f 4 , 0 0 0 , -}$ 000 .

(c) Thirdly, because the consumers' societies, as long as they confine themselves to their ordinary business, do not know what to do with surplus capital, and can find no use for it. What is the object, therefore, of running the risks, which we have just indicated, if they are not compensated for by any advantage?

Lately there has been a reaction against this spirit. Co-operators have learned to appreciate, if not the merits,

* Author's Note. To avoid or limit this danger the Swiss societies prefer borrowing in the form of bonds repayable three or five years from the date of issue. This precaution is the more necessary in that they give far more credit than do the eo-operative societies of other countries. While in Britain the loan capital is only one-eighth part of the share capital, in Switzerland the proportion is reversed; the share capital is only one-eighth of the loan capital.

On the other hand, the reserves in Switzerland are far more than double the share capital, which makes for safety, since the reserve fund is the indivisible and eollective property of the society and cannot be withdrawn, while the share eapital is the individual property of the members. The following table shows the comparative division of capital in the two countries:-

\begin{tabular}{|c|c|c|c|c|c|}
\hline Share capital & & $\ldots$ & $83 \%$ & . & $9 \%$ \\
\hline Reserve capital & & $\ldots$ & $6 \%$ & 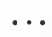 & $21 \%$ \\
\hline Loan capital & ... & $\ldots$ & $11 \%$ & . & $70 \%$ \\
\hline
\end{tabular}




\section{2}

CONSUMERS' CO-OPERATIVE SOCIETIES

at least the advantages of capital-this statement may give the ordinary economists an opportunity for a facile triumph! - and as their ambitions have increased they have found themselves hampered by the limits which they themselves have placed on capital. It is obvious that consumers' societies cannot think of engaging in production-which is their great object-without having the necessary capital to build factories or to buy land. This is why the consumers' society in Hamburg, which has the significant name "Produktion," insists that each member shall have at least four shares of 50 marks each-that is $\mathbf{f 1 0}$. The old mistrusts are in part dissipated, since, as long as capital has neither the right of control nor a share in the profits, its domination is hardly to be feared, and the desire for protection against its encroachments seems almost fantastic. Today, co-operators, fearing rather the difficulty of raising capital, are preoccupied with the means of attracting it. If there are capitalists generous enough to be prepared to subscribe for a large number of shares one can hardly see any reason why the society should fix a stern limit to their goodwill and thus deprive itself of a useful addition to its resources. If it is feared that they will embarrass the society by withdrawing in a fit of bad temper and taking with them their capital, it is possible to guard against this risk by attaching such conditions as are deemed necessary to the rules for the repayment of shares (see above, pp. 110, 111).

Further, in Britain, voices have been raised calling for the abolition of all rules limiting the number of shares which can be subscribed for by a member, and even for the abolition of the limit of $£ 200$ imposed by law; and in all the congresses it has been pointed out that it is the duty of members to leave their dividends on deposit with the society.

As for the French societies, up to the present their development has not been such as to require much capital. However, ways of increasing their resources are now engag- 
ing their serious consideration. It is customary today in French societies (though not legally necessary) to fix the value of the share at $100 \mathrm{fr}$. (ft). But they do not count much on the subscriptions of their members, and still less do they wish to apply to capitalists for the necessary capital. They have turned to the State and ask it to supply capital, as the co-operative productive associations and the agricultural and credit associations have done.

Since 1897 the State has set aside its part of the profits of the Bank of France, which today numbers a good number of millions (francs), at the disposal of agricultural credit societics, and, later, productive societies. Since 1911 a sum of $£ 80,000$ has been placed at the disposal of workmen's productive societies. Relying on these precedents, the national federation of consumers' societies has also secured an advance of $£ 80,000$, which shall renew itself as it is paid.

It is a modest sum, which cannot be of any use unless it is concentrated in the hands of a central body like the Wholesale Society, but the State could not confine its advances to the Wholesale without raising a storm of protest from the societies which are not affiliated to it. ${ }^{4}$

\section{(2) The Reward of Capital}

As we know, it is the rule that capital has no share in the profits. Where it is given a share the society ceases to be co-operative, even if it wrongly calls itself such.

This is well known, but a thing that is not generally realized is the magnitude of the sacrifice which is thereby imposed on the holders of share capital. In fact, the profit of which it is deprived is not the ordinary modest

4In the United States a few of the agricultural marketing associations have lately been able to get such help from the federal government or from one or two of the states, but the eonsumers' societies still have recourse only to the private banks, two or three co-operative or labour banks, and individual co-operators. 
commercial profit of 10 or 12 per cent., but a profit of 30 per cent. or more.

If the total profits of British co-operative societies, namely, $£ 25,000,000$, were given to share capital, which was (in 1920) $£ 86,000,000$, it would make 33 per cent. For some societies even higher rates could be found. It is only the old insurance company or the mining company which can afford us an example of equal or higher profits. These figures refer to the profits and capital of the retail societies. It is a very different matter with the two British

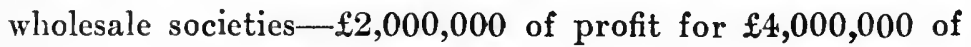
share capital, but it should be said that this share capital only represents a part of their total capital. Moreover, in 1917, the profit decreased greatly, and in 1921 there was a great loss because the wholesales tried to fight against the increase in prices.

When Fourier dazzled the eyes of the world with the dividends of his Phalansterre-24 to 26 per cent., as he saidhe doubtless had a vague vision of consumers' societies which would realize them!

Moreover, it must be admitted that when the Rochdale Pioneers laid down their famous principle of distributing the profits among the consumers they thought that these profits would be of little importance and, perhaps, if they had suspected the rate which would one day be reached, these early shareholders would have hesitated to renounce them in advance.

Thus is the question of profit settled; but there remains the question of interest, which is altogether another matter.

Ought a society to pay interest to capital-either share capital or loan capital? The answer to this question does not seem to admit of doubt. In no case does interest upon capital appear to be more legitimate than in this one. It is, in fact, a question of capital which is undoubtedly the fruit of work and savings, and which the society received 
from its own members. Further, it goes without saying that this capital is of great service to the society, it is fair that this service should be paid for. Moreover, the rate of interest is generally limited to 5 per cent., which is the rule in nearly all societies. It does not fail, however, to excite a fairly strong opposition, and not only from the socialist side. In Germany it is the rule not to pay interest on share capital. It may be said that if the share-holding member, or lending member, is loyal to the society he gains nothing by getting interest on his money, because he will get it in the form of an extra bonus on his purchases. He ought to see that if the social profits are to be as high as possible they should be free from all interest charges. If, on the other hand, the member does not use the shop, and so fails in his duty as a member, it is only fair to punish him by refusing him any interest on his shares.

This does not really get to the root of the question. The reasoning would be right if all the members had brought to the society an equal amount of capital-either in the form of shares or of loans-and if it were in their power to make the same amount of purchases; in this case it would be of no importance whether they obtained their interest separately or as part of the dividend. But neither one nor the other of these conditions is, or can be, fulfilled, and therefore it seems fair that service rendered in the form of capital advanced, which is not of less value that that rendered in the form of purchases, should be rewarded. According to Professor Hall (quoted in the Co-operative News), half of the share capital is owned by one-tenth of the members. Half of the British co-operators do not own more than three shares. It is curious to observe that in the little world of co-operators the division of wealth is scarcely less unequal than in the great world of individualists.

Is it necessary to say further, that, if the society does not allow any interest on capital, no member will subscribe for 


\section{6}

CONSUMERS' CO-OPERATIVE SOCIETIES

more than one share, since the possession of a single share entitles him to make all the purchases he desires and to gain the dividend, and that the subscription for a larger number of shares will not bring with it any advantage? $\mathbf{B y}$ this course the society limits its share capital to a minimum incompatible with progress. This is exactly what happens in Germany. Each member takes up one share only. Therefore, it is necessary to make the shares expensive-30s., and sometimes $£ 3$.

Thus it happens that even those societies which wish to remain faithful to the principle of the abolition of interest, confine themselves to the formality of paying no interest on the first share subscribed for by each member, but allow interest on all further shares for which a member wishes to subscribe, and, in any case, on money which he leaves on deposit, or invests in the form of a loan. This was the rule in the Wholesale Society of the old French Co-operative Union (which has disappeared since the amalgamation), and it is the rule followed in the big "Produktion" society at Hamburg. ${ }^{5}$

\section{(3) The Use of Capital}

We have just remarked, that as soon as a consumers' society has succeeded in getting together a good number of members it does not know how to use such of its capital as is in the excess of the needs of its business, and it finds itself embarrased by its riches. Thus the British societies, both retail and wholesale, have in the form of shares and deposits

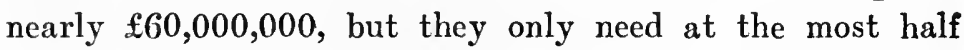
of this as working capital. Therefore, the question arises how to employ the superabundant capital.

5 A few societies in the United States are able to follow this plan of paying interest only on shares subsequent to the first, but usually (except in the weakest societies where there is no money for payment of any interest at all) the current rate of interest is paid on all shares. Some of the more radical societies pay interest only on loan capital. 
If the money be invested, as the bourgeois invest, in consols or other securities, it is giving to the capitalist organizations those very arms which have been forged for use against them; it is helping those very businesses which it is sought to supersede. What is needed is that co-operation should use these resources for its own ends, namely, in building factories and buying farms, or helping workmen's productive associations; the question which of these two systems is to be chosen is so difficult that it will be the subject of a special chapter. (See below, Chapter, X, "Housing.") For such great enterprises as these cooperation need not fear having too much capital. The English and Scottish Wholesale Societies have invested in their productive enterprises more than $£ 4,000,000$ of capital, and the retail societies have invested half this sum. The late war will have the effect of giving a strong impctus to this movement, for the rise in prices has made co-operators feel the necessity of going back to the very sources of production and controlling raw materials first of all if they wish to remedy the position. (See Chapter XV, Production by Consumers' Societies.)

There is yet another and less ambitious way of using it, but one which is of great use for the working, in fact, for all classes, and which offers the best possible security, that is the building of comfortable and cheap houses or flats. But these uses are far from absorbing all the available capital, so that more than a quarter of it is used in various other ways-public funds, mortgages, \&c.-and sometimes goes even into industrial enterprises competing with co-operative ones.

Still, partly by its use in production and partly by the building of workmen's houses, or by the increase in the range of a consumers' society's business, the greater part of the capital accumulated by co-operation returns to the people. In this way consumers' co-operative societies 


\section{CONSUMERS' CO-OPERATIVE SOCIETIES}

alrcady do a better social work than the savings banks, because the millions paid into savings banks are nearly all invested in consols (above all, in France) or in capitalist securities. As M. Luzzatti says, with his usual eloquence, "In the savings bank the poor man's mite is lent to the rich, while in co-operation the poor man's mite is lent to the poor."

In France, societies have not been so successful as to be much worried by the question of how to use their capital. As soon as they have sufficient capital their first thought is to build a fine shop, and many of them do not even wait to have enough, but borrow from their members for this purpose. This mania for building can be justified in part by the wish to show the strength of the society, and as an advertisement in rivalry to the big shops. However it is a dangerous thing, and has brought several big Parisian societies to ruin. For many of them, the day when they opened their "palace" has marked the beginning of their decay. ${ }^{6}$

${ }^{6}$ Such impatience is not unknown in the United States. The more common form of extravagance, however, is laying in excessive stocks of goods and over-furnishing the store or employing too many clerks. 
VARIOUS TYPES OF CON S MER '

S O C I T I E S

A consumers' society, to fulfil completely the definition which we have given of it, ought to be able to supply its members with everything they may require, so that the members need not spend anything outside the co-operative store. But such a complete realization is impossible under the existing economic organization. There are some social requirements which are supplied by the State, by municipalities, by private monopolies, or by the liberal professions, which are not yet, and which never will be, supplied co-operatively. We cannot, for example, go to the co-operative store to pay taxes, law costs, examination fees, or lawyers' or doctors' fees, nor even to purchase tickets for the train, tram, or theatre, though, indeed, this ought not to be impossible with regard to these last-named items. ${ }^{1}$ But, making allowances for all these expenses, which at best do not occupy an important place in the workman's budget-at the most 5 per cent., according to monographs published on the subject-a co-operative store should very easily supply cverything else -food, clothing, housing, furniture, ornaments, books, even medicine, everything, in fact, a man needs from the cradle to the grave, from the layette to the shroud. We find all these

1 There are great differences of opinion on this subject. Already there are co-operative medical societies in Europe and the excellent. sick and death benefit societies in the United States which supply doctors, nurses and hospital care to the members. We already have co-operatively owned and controlled moving picture theatres. And many of our co-operators look forward to the time when vast wholesale societies shall control the railroads, and when the activities of the co-operatives shall so encroach upon the domains of the State that its taxing power will be reduced to the vanishing point. 
services are rendered by co-operative societies abroad, and even in France itsclf.

There are two different forms of commercial co-operation, both of which have been tried with success. One is that of a universal supply store, where the consumer can obtain everything he requires; the other form is a specialized store, with a trade which is confined to some one branch, such as dairying, or the sale of wine, \&c.*

* Author's Note. The statistics of the Ministry of Labour give the following figures, which show how the consumers' societies in France (1914) are divided, according to their various functions:-

\begin{tabular}{lrccccccr} 
Various & retail & societies & \multicolumn{2}{c}{ (principally } & \multicolumn{2}{c}{ grocers) } & $\ldots$ & 1,607 \\
Bakers & $\ldots$ & $\ldots$ & $\ldots$ & $\ldots$ & $\ldots$ & $\ldots$ & $\ldots$ & 1,300 \\
Butchers & $\ldots$ & $\ldots$ & $\ldots$ & $\ldots$ & $\ldots$ & $\ldots$ & $\ldots$ & 34 \\
Wine & $\ldots$ & $\ldots$ & $\ldots$ & $\ldots$ & $\ldots$ & $\ldots$ & $\ldots$ & 48 \\
Decr & $\ldots$ & $\ldots$ & $\ldots$ & $\ldots$ & $\ldots$ & $\ldots$ & $\ldots$ & 118 \\
Restaurants & $\ldots$ & $\ldots$ & $\ldots$ & $\ldots$ & $\ldots$ & $\ldots$ & 18 \\
Coal & $\ldots$ & $\ldots$ & $\ldots$ & $\ldots$ & $\ldots$ & $\ldots$ & $\ldots$ & 31 \\
& & & & & & & & $\overline{3,1562}$
\end{tabular}

All of the 1,607 societies classed as "various" sell groceries, but 600 add bread, whilst 100 of them sell drapery, hardware, shoes, confectionery, \&c.

The societies for the sale of wine do not undertake the making of it, therefore they must not be confused with the societies of winegrowers for the manufacture of wine or for the sale of their grape harvest. The co-operative breweries, on the contrary, make the beer which their members consume, and thus, like the bakeries, participate both in consumers' and producers' co-operation.

2 Figures for the number of consumers' societics in each class for the United States are not available. Certain rough estimates can perhaps be given. Figures given below are very generous; probably they would be somewhat smaller in each case if the precise facts were known.

$\begin{array}{lccccccr}\text { Grocers } & \ldots & \ldots & \ldots & \ldots & \ldots & \ldots & 2,800 \\ \text { Butcher Shops } & \ldots & \ldots & \ldots & \ldots & \ldots & \ldots & 25 \\ \text { Bakeries } & \ldots & \ldots & \ldots & \ldots & \ldots & \ldots & \mathbf{7 5} \\ \text { Restaurants } & \ldots & \ldots & \ldots & \ldots & \ldots & \ldots & 15 \\ \text { Laundries } & \ldots & \ldots & \ldots & \ldots & \ldots & \ldots & 12 \\ \text { Dry goods, Gents } & \text { F'shings, etc. } & \ldots & \ldots & \ldots & \ldots & 15 \\ \text { Housing } & \ldots & \ldots & \ldots & \ldots & \ldots & \ldots & 25 \\ \text { Milk Supply } & \ldots & \ldots & \ldots & \ldots & \ldots & \ldots & 8\end{array}$

To be sure there are hundreds of grocery stores which carry a line of dry goods, shoes, or other essentials, and other hundreds which carry meats and fish. 
Up to the present, co-operative evolution tends to spread only in the former type; this is only to be expected, as the requirements of a workman's household are too few and the time at his disposal for making purchases is too limited for the members of it to roam from one shop to another. But this state of things might be altered if co-operation could gain headway among the middle classes. For example, in sereral large towns (London, Milan, \&c.) co-operative automobile societies have been formed which are societies of consumers, and not of producers, that is to say, societies to furnish people who possess motors with all that is necessary for their upkeep, i. e., supplies and accessories. In many towns in the United States there are also co-operative telephone societies. In fact, among all the varied requirements of man, there is hardly one which could not be made the object of a special consumer's' society. We cannot mention them all, but we shall name a few of the most important.

\section{(1) Groccries}

Most co-operative societies have started with the sale of groceries, after the example of the Rochdale Pioneers, and even today it is to this type of trade that the vast majority of co-operative societies adhere. It is not merely because this trade satisfies the most important need of man, but sim. ply because it is the need easiest to satisfy. For example:-

1. Goods sold under the head of groceries-which comprise not only foreign produce (coffee, tea, chocolate, pepper, \&c.), but also jams, sugar, dried vegetables, confectionery, and everything required for the houschold, such as soap, oil, \&c.-comprise almost the whole of the daily needs of the

Also there are many hundreds of houses that are co-operatively owned; but the majority of them are unincorporated or are incorporated under the straight business corporation law. They are not projections of the co-operative idea, but are co-operative by accident and usually not strictly co-opcrative at that. 
working population, bread alone excepted. They are sold for ready money, and this is a great point.

2. They do not need any skilled manipulation, except, perhaps, in roasting the coffee or breaking up the sugar.

3. They are easily stored and preserved, much more so than are meat, fruit, milk, butter, \&c., and involve comparatively little wastage.

4. By the variety of articles sold they insure against variations of prices, and the risks of goods remaining unsold.

5. They only need a very small capital to begin with, although the trade is capable of being developed to large proportions.

6. Finally, since it is in this department that goods are most often adulterated, it is not a difficult matter to gain a reputation for integrity.

These are all distinct advantages for men who are novices in business, as are most co-operators.

Furthermore, the best proof that this branch of trade is the most accessible of all is that of all trades that of the grocer is the commonest in every country.

Grocery shops are to be seen at every street corner, just because this is the venture every one makes who has neither the capacity nor the money to undertake another trade. Every servant, peasant, workman, discharged soldier, \&c., who wishes to settle down and become a shopkeeper, begins by buying a small stock of groceries, at least, if he cannot manage to get a license for the sale of drink. It is none the less a curious fact that a type of trade which is everywhere considered the most commonplace, and which has always been a butt for those who wish to ridicule the middle-class mentality, is the very trade which has become the nest, as it were, of co-operation, whence this blue bird has taken its flight.

The wine trade is sometimes the special object of a cooperative society (of about 50 in France, not counting the 
co-operative societics for the production or sale of wine, which are quite distinct), but as a rule wine is included in the sale of groceries and constitutes the most important line in many stores, especially in Paris. An unexpected result of this has been that during the wine crisis the enormous drop in price which prevailed in France from 1900 to 1910 re-acted very considerably on the co-operative stores, many of which had to close in consequence. The effect of a fall in prices causes an appreciable diminution of the sale reccipts, a relative rise in general expenses and a reduction of the profits. At the same time the facilities for traders to offer good wine at a lower price increases competition.

\section{(2) Bakeries}

Next to a grocery store, the most general form of cooperative enterprise is a bakery. This is the form preferred by all the Belgian and by more than a quarter of the French co-operative societies (1,300 out of a total of 3,156). A bakery, however, is a more complicated business than a grocery store, in that it is an enterprise for production, and not merely for sale.* The baker not only sells the bread -he makes it. Of all forms of production, that of breadmaking is the oldest, the most familiar, and it is still, so to speak, a domestic enterprise. It needs only a small capital, employs no machinery, and operating with raw material always more or less the same, the price of which varies but little, it has not many mishaps to encounter. On the contrary, it has many advantages superior to those of any other branch of commerce. It supplies a food of daily use necessary to human life, at least among white races, which has

* Author's Note. We must not, however, confuse the co-operative bakery for consumers with that for producers. In the former it is the people who eat the bread who get it made for themselves-as in the times when bread was made in the lome; in the latter it is the working bakers who join together to become their own employers, and to sell bread to the public. These latter societies are very rare. 


\section{CONSUMERS' CO-OPERATIVE SOCIETIES}

a large place-sometimes more than a quarter-in the workman's budget, and of which the consumption is so perfectly regulated by human needs that it hardly varies by a halfpenny a day. One knows beforehand-which cannot be said of any other kind of merchandise-what quantity of bread will be consumed in a year by each member and in total. And if the member fails for a single day to purchase at the shop his disloyalty is at once apparent, because it stands to reason that he has not gone for a whole day without eating bread. This is one of the principal reasons why co-operative societies in Belgium and the North of France prefer a bakery; it is because they have their members in this way under their thumb and under their eye. When they notice that a member has not bought bread for some days, they send round to his house to enquire the reason for his defection and, if necessary, to stimulate his zeal.

Thus, it is impossible for a society which supplies the daily bread not to take an important place in the members' lives, and to create a solid bond between them; the various kinds of bread they eat form a sort of connecting link between them. Besides, in the event of a strike or some special misfortune, the distribution of bread is an immediate and eficacious help. On the other hand, precisely because breadbaking is the most ancient form of production, co-operation can effect considerable reforms in it, as much from the point of view of production as of distribution.

We give instances here of four defects which ought at all costs to be abolished in bread-making, but which are perpetuated either by custom or sometimes by the selfinterest of the consumer. And who is in better position to educate consumers than a consumers' co-operative society?

(a) Hand-kneading.- Kneading the flour by hand is not only fatiguing for the workman who has to do it (hence his name "geindre," meaning to moan), but it is also, as far as 
the consumer is concerned, a disgusting operation, and perhaps dangerous, where the workman is affected by tuberculosis or other disease, if the heat of the oven does not permeate the dough sufficiently to kill all the germs. Custom - that of the bakers themselves, as well as that of the public - has hitherto been opposed to the employment of machinery, but the majority of large co-operative bakeries have succeeded in introducing it and accustoming their clientèle to its use.

(b) Night Work.-Bread is made at night. Why? Simply that the public may have fresh bread for their breakfasts. But night work is very exhausting, particularly when constant and performed in underground bakehouses and badly ventilated basements. How can we put a stop to these evils, and free these galley slaves? Simply by the consumers being content to eat yesterday's bread for breakfast, which at any rate they could always use in the form of toast. It is not an easy matter for the law to prohibit night work in an industry which is more or less a domestic one. It lies, therefore, with the public to liberate these workmen, and in a large number of societies the consumers are always being educated in this respect.

(c) Orer-dressing of Flour.-In order to have the flour very white, as in Paris, it is "dressed" to 60 per cent.even to 55 per cent. - which means that nearly half of the flour is thrown away with the bran, which is an enormous wastage. Moreover, this very white bread, though more pleasant to the palate when fresh, is hardly eatable when stale, hence another wastage, as pieces of bread left over from the day before are often put into the dustbin. A city workman throws away stale bread. An enormous economy, which would run into millions of bushels of wheat, and hundreds of millions of franes, * would be to restore to the people

" $\Lambda$ uthor's Note. Freneh people consume an average of $1 \mathrm{lb}$. per 


\section{CONSUMERS' CO-OPERA'TIVE SOCIE'TIES}

(without taking us back to the black bread of our grandparents) the taste for bread from which raw material has not been so eliminated, and which would be yellower, of more pleasing flavour, richer in nutritious matter, and easier to keep in eatable condition.

Co-operative societies have tried to educate the public in this respect. Perhaps they would not have succeeded, so strong was the opposition, had not the war come to teach the lesson. Leaving Germany out of the question, from the month of May, 1916, French law prohibited the dressing of bread below 77 per cent., and every one found the new bread excellent. In Italy the law has imposed a dressing of 85 per cent., which makes the bread quite brown.

(d) Unecessary Producers and Retailers.-The organization of the bread trade is very much out of date and puts a heavy tax on consumers, which must amount to hundreds of millions. If, however, modern and more perfect methods were employed in baking and in milling, and if these operations were undertaken on a sufficiently large scale, it would be possible to deliver bread almost at the price of wheat,* weight for weight, i. e., about $21 / 2 \mathrm{~d}$. (price of wheat before the war). It was sold at from $31 / 2 \mathrm{~d}$. to $4 \mathrm{~d}$. per kilo, ${ }^{3}$ which means an increase from 40 to 60 per eent. on the price of wheat. When we consider that there are seven milliards of kilos of wheat consumed annually in France we can calculate

head daily, which means 7 milliards of kilos a year. These 7 milliards exact, if the dressing is done at 60 per cent., 117 millions of quintals of wheat, and if the dressing is done at 77 per cent., only 90 millions, which is a saving of 27 million quintals. As a matter of fact, the saving is probably not so great, as the flour was not universally dressed at 60 per cent., but even if the saving is less it is not ncgligible. (1 quintal $=1.968$ cwt.)

* Author's Note. Wheat loses a quarter of its weight in the grinding, but this is regained from the water and the salt nccessary to make the dough, so that $1 \mathrm{lb}$. of wheat gives $1 \mathrm{lb}$. of bread. As to the expenses of milling and bread-making, they are so insignificant with the modern machinery that the bran and the offals are almost enough to cover them.

3 A kilo comes to about $2 \mathrm{lbs}, 2 \mathrm{oz}$, 
how large a sum is needlessly squandered.* And let us remember that this enormous rise in the price of bread is not connected with the bakers' profits (these are generally very much diminished owing to the ridiculous multiplicity of bakers, all in competition with one another), it is accounted for by the increase in general expenses and the decrease in demand which this very competition means to each producer. In Paris we reckon one baker per every 1,300 persons; in Lyons, one per 600 ; and in St. Etienne, one per 380 . Each baker can only make from 200 to 600 kilos of bread daily. And upon that he must find means to live, and to pay the rent for his shop and oven, his taxes, his workmen, and his delivery men! ${ }^{4}$

How comes it then that the law of concentration has not been effective in this domain, as is manifested in so many others, in groceries or clothes, for instance? It is not very easy to find an explanation. Probably we must look for it in the neighbourly relations which spring up between the baker and his customers, in the custom of delivering bread at the houses, perhaps also in the custom of giving credit. But all these obstacles are not insurmountable, and if capitalist enterprise has been unable to organize bread production on a large scale, co-operative enterprises has succeeded in doing so.

As soon as a co-operative bakery has assumed large enough proportions it is no longer content to buy flour for

* Author's Note. One portion of the French rural population already receive the benefits which might accrue to them by co-operation, because they make their own bread. However, these people are gradually giving up home-baking, for even the peasants now buy their bread from the baker, except those who live very far away from any village.

4 Some of the larger cities of the United States have co-operative bakeries. Always, however, thy find it difficult to compete with the small cellar bakery manned by the owner, an apprentice, and several members of the owner's family. The Jewish co-operative bakeries, compelied to pay high union wages to every employe find this competition especially trying. 


\section{CONSUMERS' CO-OPERATIVE SOCIETIES}

making its bread; it buys wheat to convert into flour, i. e., it adds a mill to the bakery, thus fulfilling what is called the law of integration of industry. The Rochdale Pioneers took over a small mill soon after starting, but this premature venture nearly ruined them.

A small co-operative bakery could hardly sell bread cheaper than the baker, it could only add to the weight of the loaf; but when the co-operative bakeries have thousands of members they can work a veritable revolution in this primary branch of commerce. When, as in the co-operative bakeries of Glasgow, Lille, or Roubaix, they are able to sell from 20,000 to 40,000 kilos of bread daily, then they can, even while selling the bread cheaper, distribute about $1 \mathrm{~d}$. dividend per kilo, that is to say, bring down the price of bread to $21 / 2 \mathrm{~d}$. instcad of $31 / 2 \mathrm{~d}$. (current price before the war). There are a great many rural bakeries in France (more than 500) owned by peasants who harvest the wheat and transform it into bread. It is the ancient domestic industry of bread-making which exists, and is being gradually transformed under this collective system, which comes as much into the field of production as into that of consumption. Some of these societies own a mill and grind the wheat into flour themselves; the majority deal with a miller.

\section{(3) Butchers' Shops.}

Of all branches of commerce it seems that this ought to be one of the best suited for co-operation, because the prices of meat are generally very high, particularly in France, resulting in the reduced consumption by French people, which is two-thirds that of the English (50 kilos a year instead of 70 ); moreover, the retail price seems entirely disproportionate to the price given for the animal, particularly just now when, consequent on the war, meat is excessively dear.**

* Author's Note. Vegetarians say that this is a good and not an 
Nevertheless, there are only a very few co-operative butcheries, about forty in France, and still fewer in other countries. ${ }^{5}$ Of all forms of enterprise, this is the most diffcult to organize co-operatively. The following are some of the reasons for this-we need only mention them summarily, as they are sufficiently clear:-

(a) Because meat is very difficult to keep and of irregular sale, and because the price of the raw material (the animal) is extremely variable, which often exposes the retailer to heavy loss.

(b) Because meat is the commodity which least lends itself (by reason of the variety in quality of the cuts-meat is divided into 10 or 12 different categories-the prices of which vary enormously) to the maintenance of the equality which should naturally exist among members of the same society; this difference in quality may often lead to discontent among the members.

(c) Because, contrary to what we might imagine, the butchery trade pre-supposes very special technical capacity, as much for the buying of the beast as for the manner of retailing the various portions-of including bone or fat, of passing them from one category to another-and in this last it is difficult to dispense with "the master's eye."

evil, and that it is better not to increase the consumption of meat. We eamot diseuss this question here. Vegetarianism is supported by very strong arguments, and we incline to the belief that it has a future; but it must be admitted that so far meat-eating people are at the head of the industrial movement.

5 There are more than this in the United States, but many of them are run in conjunction with grocery stores. Usually the Jewish people begin with bakeries or butcher shops rather than with the more difficult grocery. However, all societies find the butcher shop very diffieult of control by the directors. A control committee knows exactly how much to expect from the sale of the produet of $b$ given number of harrels of flour in the bakery and it can foretell to a nicety the retail value of the eontents of a grocery store; but even the skilled hutcher cannot tell how much to expect to realize from the carcase of an ox or sheep. Therefore the directors have to trust to the honesty of the butcher they have hired. 


\section{CONSUMERS' CO-OPERATIVE SOCIETIES}

(d) Because a wide latitude is required in fixing prices, \&c., for each portion: a butcher will lower the prices or offer more advantageous terms for cuts still unsold towards the end of the day. These are liberties which an owner can take, at his will, but which it is not always advisable to put into the hands of a paid manager.

(e) Finally, because the butchers have an arrangement among themselves, whereby they can dispose of superfluous cuts, when there is no sale for them among their customerscheaper cuts to such a one-and choicer cuts to another, and so on. But a co-operative butcher would not have this resource, as the other butchers are always in a state of open or tacit coalition against him. And this coalition can even make the purchase of an animal a difficult and onerous business for him.

However, a butchery succeeds best when, instead of making it a self-supporting co-operative enterprise, it is merely a separate department in a general supply store. The general expenses are thus reduced and the risks are covered by the combined operations.

For meat as well as for bread, co-operative shops have rendered an important service by the sale of frozen meat, which the agriculturists in France had succeeded in arresting, by prohibitive taxes and under vain pretexts of hygiene. The co-operative stores, however, would not have been successful in this, had not the war and consequent lack of meat. forced the Government to change its policy.

But, as there was no organization, and as the butchers showed themselves disinclined to facilitate the sale, it was the co-operative stores which took up the matter in Paris, with the aid of the municipality of Paris, the Department of the Seine, and the State. It was the State, or rather the military authorities, which provided the meat bought in England. It was the town and the Department of Paris which provided the market places and the costs of their 
installation. This meat could only be sold at the controlled price. Today, the use of frozen meat has becone general in France, and it may be said that this beneficent revolution is solely due to the initiative of the co-operative socicties.

However, it is difficult to control the price of meat by governmental action (although it was permitted by French law even before the war), on account of the differences in quality. Municipal butcheries have been tried in small towns, and with success, but co-opcrative ones would be preferable.

\section{(\$) Restaurants and Licensed Cafís}

Why should not a consumers' society, instead of supplying raw foods, furnish them ready prepared for consumption? There is no doubt that this can be done, in which case the socicty becomes no longer a shop, but a restaurant, perhaps independent, or perhaps simply an annex of the grocery, of the butchery, or the bakery. But such co-operative restaurants are still very rare; there are only about fifteen in France. Many of such restaurants have failed. This is, first of all, because their clientèle is much too limited. Naturally they have not the custom of any of their member's who lead a family life - and these are the most numerous-or even of those unmarried ones who prefer to take their meals at home. And on the other hand, they cannot count on travellers, like ordinary restaurants, because these, who by definition are only casual passers-by, cannot form a co-operative society. So we see that co-operative restaurants can cnly supply a very restricted class, such as students going through courses of study, * workmen, and more particularly

*Author's Note. Among these there is one in which we werc personally interested, the "Restaurant Cooperatif des Etudiants," of which we gave a very instructive account in the Revue de l'Enseignement Superieur, 1905. It came to an end after three ycars (1901-1904), but was started again in a very unassuming way, substituting a fixed price (1s.) for a meal, instead of service i la carte. The success of the 


\section{CONSUMERS' CO-OPERATIVE SOCIETIES}

workgirls, obliged to work at a good distance from their dwellings, the midinettes, as they are called in Paris. ${ }^{6}$ For these last such restaurants would serve a useful purpose. The population of several French towns, such as Bourges and St. Etienne, was about doubled during the war, owing to the erection of huge factories with thousands of workers. This necessitated the building of large workers' restaurants. The Minister of Munitions, M. Albert Thomas-fortunately a most ardent co-opcrator-gave a great impetus to this movement. The State furnished the necessary capital, and the French National Federation undertook the responsibility of working them. There were 119 restaurants and 813 stores established, which were managed by working men co-operators, with a turnover of $£ 3,640,000$ during the first quarter of 1918, diuing which period 161 restaurants and 320 shops were opened by the manufacturers themselves, but whose total businesses scarcely reached $£ 640,000$. Meanwhile, branches have sprung up all round Paris, which still exist (1921).

This population is necessarily somewhat fluctuating and irregular; in any case, it changes very frequently, and is not at all suitable for co-operative association, which requires regularity and continuity. Moreover, the legal forms, with share subscriptions, gradual payments, the various responsibilities and consequent formalities, are ill-suited to a floating population. Thus in this case it seems preferable to employ the philanthropic form, i. e., the restaurant founded

new restaurant for students seemed almost assured, but unfortunately the war came and put an end to it.

6 Many of the American cities have restaurants organized among the single men of a given community. In Brooklyn such a society also feeds many of the school children in instances where both parents are at work all day. A restaurant like this often provides for the nceds of the whole family. There are a few colleges which have cooperative dining halls among the students. One very successful cafeteria society is looking forward to the time when it can establish delicatessen departments. 
with money furnished by some generous capitalists; the goods are thus delivered at cost price, but the consumers do not acquire the rights, nor do they undertake the obligations, of members. Such is the co-operative restaurant at Grenoble called "Association Alimentaire"-founded in 1851, the oldest and most prosperous of them all. It is co-operative in name only, because it serves the public rather than its nembers. 'To become a member an entrance fee of $10 \mathrm{~d}$. is all that is necessary. The only right which membership confers is that of taking part in the general meeting and in the election of the committee of management. There is no distribution of dividends, but the profits are placed to a reserve fund, which is drawn upon for the regulation of prices. This fund is added to when, owing to commodities being cheaper, the restaurant can make good profits, and in like manner the fund is resorted to when business is carried on at a loss, owing to the price of goods being high.

It is quite possible, however, that the co-operative restaurant is destined to have a considerable development, both for middle-class housekeepers, owing to the increasing difficulty of obtaining servants, and for working-class households, consequent upon the distaste for cooking which their women will evince, in proportion to the spread of the feminist movement. But under these circumstances the co-operative restaurant will become rather an annex of the communal dwelling. This is the problem that arises in the United States. On the one hand, it is difficult to obtain domestic servants there, and they demand enormous wages. On the other hand, American women, even workgirls, are hardly ever inclined to do housework, and do not appear to have much aptitude for it. Under these conditions there is hardly any other prospect for middle-class households, but to live in lotels or as bachelors at clubs, and for workmen's families to buy ready-cooked food. Here we are on the road which must lead us sooner or later to the realization of Fourier's 


\section{CONSUMERS' CO-OPERATIVE SOCIETIES}

Phanlanstère, the communal household taking the place of the family dwelling.

Co-operative cafés would seem to offer better prospects of success than restaurants, in so far as that their clientèle is more stable. In every town, more particularly in small ones, regular customers ("habitués") are always to be found. Then, too, an enormous economy would be realized, because the price of liquors has increased in formidable proportions. But notwithstanding this, co-operative cafés have had even less success than co-operative restaurants. I may say I do not know of a single example in France of a genuine co-operative café. The explanation for this is simply that the habitués of a café do not go there as a rule either from a spirit of economy or to serve any social ideal.

Attempts have been made to establish cafés, or wine shops, which would be both co-operative and non-alcoholic. But so-called temperance cafés have never had much success in France, and still less under a co-operative form. Up to the present the French working-class-even the most advanced -has been absolutely indifferent to the anti-alcohol campaign. The majority of co-operative societies sell distilled liquor, and often find it the most profitable part of their trade. (Siee page 96, "Division of Profits.") Perhaps this will be otherwise after the war. How very different is the attitude of the Belgian socialist workmen, who, under the inspiration of their chiefs, and particularly of M. Vandervelde, have banished alcohol from all their co-operative stores! And it is noteworthy that in France it was only among the socialist group that a few societies followed this lead.

We should mention a special type of co-operative refreshment house or café which has increased very much for some years past, and has caused a good deal of discussion, even in the Chamber of Deputies-we mean military co-operative cafés or canteens. These are not to be confounded with the large officers' clubs ( see page 102), but are small clubs 
started in barracks to supply soldiers with liquor at low rates, and with games and various kinds of recreation. Many of them do not exact any subscription, the preliminary expenses of fittings and installation being paid, or at least advanced, out of the regimental funds. Some of them demand a contribution of from $1 \mathrm{~d}$. to $21 / 2 \mathrm{~d}$. per month for each nember. The profits realized by these clubs are deroted to movements for education, for provident funds, or for "works of solidarity," such as libraries, benefit societies for soldiers' families deprived of their means of support, travelling expenses for soldiers on furlough who wish to visit their homes, or even a superannuation fund for discharged soldiers.

These military co-operative clubs or cafés have been subjected to many attacks, notably from "cantiniers," who have naturally suffered serious loss through their existence. And formerly some commanding officers have been known to lend an ear to their complaints, and have consequently put a stop to these clubs, or at least have hampered their operations, as for example, by forbidding them to sell wine. Others have taken the pretext of some abuse, unfortunately only too frequent, to declare that these clubs only serve as a cheap means of getting drunk and that they were the cause of loss of time to the officers who organized them, who had something better to do than to become retail dealers. The war has had the effect of giving an unexpected advertisement to the military co-operative societies. In the French army there was one for each division, and they have been so useful to the soldiers that they were able to do without the food which was sent by their families each week.

Why should not this co-operative system extend to food? The men's canteens and the officers' ness are already, in fact, co-operative food suppliers. It would only mean giving them a better form of organization, and having them worked by the people interested and giving them the partic- 


\section{CONSUMERS' CO-OPERATIVE SOCIETIES}

ipation in the profits. In fact, some regiments have already begun to work their clubs in this manner. We can cite the co-operative societies of the Republican Guard at Paris, which in the first six months of 1907 had repaid the $£ 1,280$

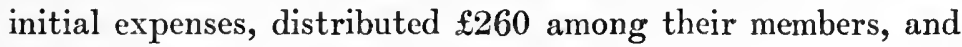
placed $\mathfrak{£ 4 0 0}$ to a reserve fund.

\section{(5) Pharmacies}

In Brussels, in Milan, in Geneva, and other places abroad there are co-operative pharmacies which have succeeded brilliantly, which is easy to understand, because not only do they sell medicaments at half-price, but they even reimburse to their membcrs more than half the value of their purchases. The society "Pharmacies populaires" (People's Pharmacies) in Brussels, founded in 1882, sell at 50 per cent. below current price, and yet their profits were 60 per cent. in 1909 on the total sales, of which 56 per cent. were distributed among their shareholders. If we make a calculation we find that this represents a reduction of 72 per cent. These Brussels pharmacies are, in fact, mutual pharmacies, since all their shareholders are mutual aid societies, but they also have the right of selling to the public.

We must admit that these enormous dividends are not due merely to the elimination of the excessive profits which chemists add to the prices of medicine, but also to the fact that these co-operative pharmacies sell to the public as well as to their members and distribute the dividends solely to their members, which almost doubles each member's share. But this system is, we are aware (see page 74) more commercial than co-operative.

But even by restricting the sales to members only, or by distributing dividends only on their own purchases, the cconomy effected would be considerable (from about 30 per cent. to 60 per cent. on current prices), more particularly if worked on a large scale, as in Brussels, with a central ware- 
house for the manipulation and handling of drugs, \&c. It is clear that these pharmacies would be extremely useful to people of small meáns, when they find themselves under the unfortunate necessity of having to send to the chemist. Moreover, these pharmacies could exereise a beneficent influence on the public health, by giving and prescribing treatment for the less dangerous maladies.

This form of co-operation does not exist in France, because the law only permits certified chemists and proprietors of their own laboratories to sell medicines. It only excepts socictics for mutual aid, which may sell medicines to their members, on condition that their manager has a pharmaceutical diploma. Thus, the great society at Puteaux, " $L a$ Revendication" has formed a mutual aid society composed of its own members. A monthly deduction of 5d. per member (5s. a year) from the dividend is sufficient to start the society and to equip the pharmacy.

The creation of these so-called mutual benefit pharmacies, which are in reality co-operative, has given rise to numerous law suits, the chemists, enraged at this competition, having attacked the societics in court, as being contrary to law. The court decided in favour of the co-operative pharmacies (notably in the case tried before the court of the Seine, in $r e$ the "Revendication" of Puteaux).

There were even some orders and some general administrative regulations which laid it down that the exigencies of the law only apply to pharmacies which sell to the public and not where they sell only to those who have created them for their own needs-co-operators or "mutualists," no matter which. But the law is not absolutely definite in this matter.

French co-operative socicties could, it is true, avoid this difficulty by transforming themselves into mutual aid societies, but this would only present fresh difficulties, such as the following: (1) In every case the laboratory for the sale of medicines must be completely separated from the other 
shops; (2) the capital required for establishing the pharmacy (not very considerable, $£ 250$ to $£ 300$ ) can never be acquired in the form of shares, as in this case the society would be the legal proprietor of the pharmacy, and the law would thus be contravened; (3) sales to the public would be prohibited; (4) and, finally, if there are any profits, they may not be distributed among the members, but must go into the general funds of the society.

It is only very flourishing co-operative societies which can open branch pharmacies, because it has been generally estimated that about 2,500 is the minimum number of clients necessary to the successful existence of a pharmacy. But what small isolated societies are unable to attempt becomes quite possible if these societies federate in large co-operative unions, such as those of which we shall speak presently. However, as the majority of co-operators in France are already, or will become, shareholders in mutual insurance societies, and as such benefit by reduced tariffs at the ordinary chemists, it cannot be said that the absence of co-operative pharmacies is a great loss to the working population.

In Britain, co-operative stores have not these difficulties, and they are free to establish a branch or department for pharmaceutical as well as any other class of goods, but only on condition of having a qualified chemist at the head of this department. There are only very few, however, which have hitherto availed themselves of this opportunity.

\section{(6) Housing.}

We have said many times in our book-and we cannot repeat it too often-how great is the importance of housing, not only for the comfort of the individual and his family, but also from the point of view of hygiene and social morality, and of the campaign against tuberculosis, alcoholism, and prostitution, and, on the other hand, how very difficult 
it is for this urgent need to find a solution under present economic conditions.

Of all expenses, that of housing is the most certain to increase; it is of the most rapid growth and the most disproportionate to the working man's budget.

This being so, why does not co-operation take up the matter of providing for this urgent need, as well as for others? In fact, it has not failed to do so, either in the form of a society specially constituted with the aim of providing this necessity, called a co-operative building society, or by including house building in the general operations of a distributive society. In this case, the co-operative store will have a house agency department, in the same way as it has a furniture or a hardware department. ${ }^{7}$

(1) Let us take the second system in the first place. For a distributive co-operative society to be able to add to its trade the letting, \&c., of houses it must have attained very large proportions and very considerable capital. In fact, to build houses, and particularly to be able to build enough to meet the demands of its members, would necessitate very

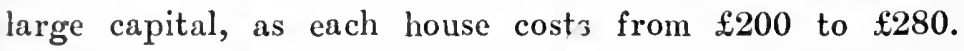
(Now that the cost of building has nearly trebled, the problem is still further complicated.) And again, the capital sunk in this real property can only be returned very slowly, as these houses may be sold to members who can only pay by gradual instalments over a period of from 15 to 25 years; or it may be that they are simply let, in which case the socicty must deduct from the rents the necessary premiums towards repayment of the capital expended. But if a distributive society has a large capital, which is not indispensable to its trade, then house building is certainly one of the best possible uses to which this capital can be applied.

7 The few housing co-operatives in the United States are for the most part organized as separate societies. 
The distributive societies in Britain have already reached this stage; many of them cannot utilize their capital to its fullest extent in their trade, in fact, so much is this so, that several of them pay it out to their members. Indeed, we have already said (page 116) that of the capital which they have acquired only about half is necessary to their trading operations; this leaves about $£ 40,000,000$, at their disposal. However, about $£ 8,000,000$ only have been spent on buildings, that is about 40,000 houses, which, if they were put together would represent quite a large town. (Paris has less than 100,000 houses.) Only about one-third of the societies do any house-building. And among these societies there is only about one-third which do the actual building themselves. The others confine themselves to advancing the money for their members, so that they may get the building done themselves at their convenience. Members find this latter method more convenient, even though it is less economical. But British co-operators think that this is not enough, and they intend to pursue this matter further. One society, that of Woolwich, near London, has decided to build 4,000 houses for itself, at the rate of 400 a year, on a vast property which it has bought, and this colossal undertaking is already well under way.

In France there are, as yet, no consumers' societies which build houses to sell to their members, but there are some (the Famille de Saint-Denis) which, when they are erecting premises for their shops, warchouses, \&c., have flats built on the upper stories which they let to their members.

(2) Co-operative building societies, i. e., societies formed specially for the building of houses, have gone much further than this; houses built by them may be reckoned by hundreds of thousands in the United States and in England, and in a lesser degree in Germany, but their organization is very much more complicated than that of an ordinary consumers' soci- 
ety. ${ }^{8}$ The reason for this is very easy to understand. As these special societies, unlike consumers' societies, cannot dip into the reserves of a capital accumulated for other objects, and as they cannot hope to obtain the capital from their members-because if the members had sufficient capital to build houses for themselves they would never dream of promoting a society for that purpose-they are obliged to procure capital in the form of a loan from the public: from the savings banks, as in Belgium, or from the municipalities as in Germany. Meanwhile they can do better; they can create a class of associates who will join the socicty simply to invest their savings, and not to get a house built, and consequently will furnish the necessary capital for supplying applicants with houses. These lenders, however, are really members and not merely lenders of money: in fact, they must subscribe for shares, and it is just the successive payments which they have to make in order to pay for their shares in full (generally, the fairly high sum of £200), which make them members and which have the advantage of making their savings regular and obligatory. Nevertheless, as the members' contributions will only be fully paid after a long time, it becomes essential to procure capital elsewhere, while waiting, in order to be able to provide houses immediately for those who demand them. This is why building societies are obliged to have recourse to the savings banks, or dircetly to the public. The members' contributions are then used merely to redecm these loans. It is this latter system which is employed in England and the United States in their loan and building socicties, which have given wonderful results. But we cannot enter into details of these diverse organizations, which are very complicated.* In France there

8 See Editor's note on page 51 concerning these associations in the United States.

* Author's Note. We may sum up as follows: the societies require contributions from their members in the form of share subscriptions, calculated so as to represent a sum equivalent to the value of the 


\section{CONSUMERS' CO-OPERATIVE SOCIETIES}

were in 1917 only $2 \% 2$ co-operative building socicties, not including 164 philanthropic or semi-capitalist ones.* They procure their capital fairly easily from the public, as they can offer the land and the houses as security. They would prefer to borrow it from the savings banks, or from the Government deposits and consignments office, because they would pay a smaller iuterest; but these, though authorized by law to lend the money, are not very enthusiastic in the matter.

There is no form of co-operation which has been so favourably treated by the legislature in France. They have encouraged it in many ways: First of all by creating public housing offices, which should exist in every town, but which in reality exist in few. Second, later, by opening the public funds to these societies, savings banks, government deposit and consignment offices, even those of the asylums and hospitals. However, the trustees of these funds must be willing to lend-but as a matter of fact they seldom do lend.

Thirdly, the State grants fairly important exemptions from taxation to the building societies: ground rent, doors and window tax, registration and mortmain tax.

house, but payable only by annual payments graduated over a period of 15,20 or 25 years. The payments are simply credited against the cost of the house until the time when, the full amount having been paid (i.e., all the shares paid up), the tenant finds himself transformed into the owner. These delays are shortened because all the profits of the society being put to the credit of the members increase their contributions and hasten the "maturity" of the shares, in the picturesque language of the Americans.

One of the most ingenious devices in these American building societies is the auctioning of the houses as soon as they are built. It is the highest bidder who gets the property. Some people will say that this system is hardly fair. But it must be noted that the excess value paid by the bidder comes into the common fund, swells its receipts by so much, thereby profiting every one, even the dispossessed ones, who can console themselves by the reccipt of larger dividends.

* Author's Note. There are many more in Germany. But they are meant for a more well-to-do class of the population, as the average cost rises to $£ 72$ per house instead of from $£ 40$ to $£ 48$, as in France before the war. In Germany, the middle-class is very well catered for, but the industrial class is extremely badly housed. 
In spite of all, the results are only very mediocre, because in 1913 the grounds laid out and buildings raised by the cooperative societies only represented $£ 1,320,000$, which-at the rate of $£ 240$ per house or flat (land included)—would only mean the housing of 5,000 families. It is true, as $\mathbf{M}$. Cheysson remarked in his annual report on the Cheap Housing Societies, that these expenses do not include those for houses already disposed of and paid for, nor those incurred by societies which were dissolved after having concluded their work. Nerertheless, even if these figures are doubled they are not sufficient for present needs. The results obtained by philanthropic building societies, and especially by employers for their workmen in their factories, are very much higher. ${ }^{9}$

Whether it concerns consumers' societies which have undertaken the building of houses, or special building societies, the question arises: Is it better to sell the houses, or merely to let them?

For a long time the first method was the one taught and practised without discussion; it was believed that the owning of a house had a good effect on a workman; that, at any rate, it constituted for him, on account of the gradual payments exacted, a method of investment and of compulsory thrift superior to any other. Even to-day nearly every building society practises this system. But the consumers' societies which do building tend rather to prefer the second solution, i. e., to keep the ownership of their houses themselves for the following reasons:-

(1) To preserve the right of control over these dwellings

9 Building has been almost at a standstill for several years in the United States. Even special laws by several states exempting new buildings from taxation have not succeeded in accelerating the industry. Excessive building costs added to widespread evidence of grossest kinds of graft on the part of building contractors and dealers in building materlals-these have discouraged private enterprise. Co-operators, faced with the same handicaps, and inexperienced in this form of activity, have not yet bccome aroused to the possibilities before them. 


\section{CONSUMERS' CO-OPERATIVE SOCIETIES}

in order to keep them in good hygienic condition, and thus to avoid the abuses which too often occur when the workman, having become proprietor of his house, degrades it, introduces lodgers, or sub-lets it-exploiting perhaps his own comrades thereby, as he was formerly exploited-or re-sells it, perhaps, to a keeper of a tavern!

(2) To keep for themselves the enormous increases in value of houses, and also of land for building, in all growing towns -increases have been the source of colossal fortunes. These enormous increases in value are very difficult to justify on the grounds of justice, as they are due purely to social causes-explained by the terrible term of the economists, unearned increments. Henceforth these houses would no longer be swallowed up in individual ownership, but would remain the collective property of the society. If this system were to become general we night thereby have an economic revolution in urban property.

(3) To allow workmen more independence, because to be the owner of a house may become somewhat irksome to a workman. It is a good thing, not only in the workman's interest, but also to prevent the general depression of wages, that labour should be mobile and able to move freely to wherever there is the greatest demand for it. I must add, however, that societies which make a workman a house-owner have also discovered ingenious methods whereby he may retire from his ownership should he so desire.

In England, in addition to consumers' societies for supplying houses, there have been formed associations of tenants called Tenant Co-partnership Societies, which aim merely at providing comfortable and cheap houses, but which differ from ordinary building societies in that their members do not desire proprietorship of the houses. Although they are of very recent date, there are today about fifty societies which have built more than 10,000 houses, valued at

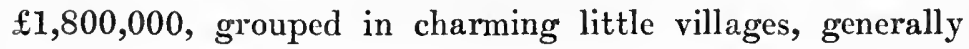


near large towns. They are, however, indirectly houseowners, being shareholders in the society which owns the houses. But they have at the same time security of tenure, as they cannot be turned out, nor can their rent be raised as long as they pay it regularly; they are also free to leave when they like, whether they give up or retain their shares.

Tenant societies are generally found outside large towns, in order to gain more air and space, and in order that each house and the entire colony may be surrounded with trees and foliage; therefore, they are called garden cities.* Their aim and ambition is to start an entirely new era in the evolution of house-building. The views of the advocates of garden eities may be summed up as follows:-

Existing towns which have grown and expanded under the pressure of causes purely historical, political, and economical, must always remain under defective conditions from

"Author's Note. The word "garden city" having become the fashion it is used even where it has no proper significance, as, for instance, where there are a certain number of cheap houses grouped by a building society round a mine or a factory. This word should really only be used where there is a "city," with all that is implied thereby: economic life, social life, civic life, \&c. $U_{P}$ to the present there is only one which has the right to the title of garden city, the small town crcated in 1901, near Letchworth, not far from Cambridge. This little town, huilt by a society hoping to realize the program of Howard's book, "To-morrow," has from 8,000 to 10,000 inhabitants. It is not, properly speaking, co-operative, as it is open to any one who wishes to come and live there, and not only to members of the socicty; but it contains various independent co-operative associations, for building, for consumption, and also a tenants' co-partnership socicty. If all the members of this town were members of these associations for distribution and for housing, \&c., which exist in it, Fourier's Phalanstere would be very nearly realized. Another garden city has just been formed (1918) at Welwyn.

The small tow'n of Milanino, founded in 1909, in the outskirts of Milan, by the large Co-operative Society of Milan, or, rather, by its director, Buffoli (now deceased), is also a remarkable cxample of a garden city-or, at least, of a society of tenauts' co-partnership. The houses there are not exclusively reserved for members, but members have the right of preference, and have the sole right to the profits, which are very small up to the present (1.75 per cent. in 1915). 


\section{CONSUMERS' CO-OPERATIVE SOCIETIES}

the hygienic and æsthetic point of view. Moreover, all the rent value of the land profits individual proprietors only and becomes a source of colossal and most unjustifiable fortunes. Every effort which is made by co-operative association and otherwise to change this state of things will inevitably be fruitless, as long as the house is in surroundings which must have a vitiating effect upon it. The only solution, therefore, is to go out of the towns and build new cities outside them in the country, on a rational plan. The land and the house will be the property of the co-operative association, or of the commune, here one and the same thing.

Here again, the war will have served to popularize the idea of garden cities. The sad necessity of rebuilding towns - several partly, at least, in France and Belgium, and 3000 entire villages-has naturally evoked new plans of organization in which hygienic and æsthetic considerations will happily have a large place. In May, 1916, in spite of the war, there was a Model City Exhibition opened in Paris to popularize the teaching of this new science, town-planning. The teaching of "urbanism" has just been started by the city of Paris. There are not yet any garden cities in France. There is, however, a co-operative housing society called "Jardin Paris."

\section{(7) Societies for Intellectual and Recreation Purposes.}

By this heading we mean co-operative societies whose aim is not the supplying of material, but of intellectual, spiritual, and artistic needs. We might have co-operative universities, co-operative journals, co-operative theatres, co-operative churches (these we have already where the separation of Church and State is effected), and co-operative cafés (we have these, particulary in our clubs and casinos). It is noteworthy that these several requirements are precisely those best suited for co-operation, because though a man may be able to work, buy, or consume individually, it is a very 
different matter when it comes to educating, improving himself, or amusing himself alone. It is not particularly entertaining to play solitaire or patience for any length of time! However, these intellectual co-operative societies are only "desiderata" up to the present time.

In a large number of universities in the United States there are, among the students, co-operative societies for the sale of all the requirenients of students, but chiefly for books and stationery. The Harvard University society had a

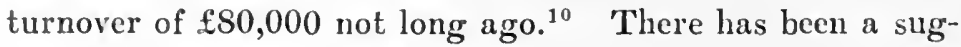
gestion of introducing this practice into France, with the addition of the printing of theses-which is a heavy expense for students-but nothing has, as yet, been attempted in this direction. Even co-operative societies for the sale of text-books and so on, among teachers and among Protestant pastors, are only, as yet, projects. A society of readers might also be formed, not to buy books, but to borrow them in rotation for reading, which is also a form of consumer's' co-operation.

From time to time the question arises of co-operative newspapers, but this may be taken in two different senses. We do not mean by this the newspapers published by large cooperative societies or co-operative unions, which exist everywhere, and some of which have a circulation which might be envied by big political journals. (See page 97.) It may be a society for subscribers who join together to have a newspaper they like, or it may be a co-operative society of writers who combine to get the profits. In the first case it is

10 Such societies, however, have not been of much value to the movement generally. Most of these societies entirely neglect educational work, the students take almost no part in the management of the societies, and the average boy or girl in many of the universities of the country where such societies exist passes through his four ycars of experience knowing the "co-op" as nothing more than a commercial establishment which rebates to its patrons each year a part of its profits. This is the writer's experience with one of the largest of these university societies. 


\section{CONSUMERS' CO-OPERATIVE SOCIETIES}

a society of consumers, in the second it is an association for production. Some attempts have already been made under the second form (notably with the Mercure de France), but none, as yet, under the first form; this is, in fact, much more difficult to realize.

The same may be said of the co-operative theatre, which has already been essayed under the form of co-operative production (the Comédie Française is an association for cooperative production, the oldest of them all), but nothing in this way has been attempted under the form of consumers' co-operation. However, as soon as enough subscribers can be found among the audience, these subscribers have but one step further to go in order to become co-operators. ${ }^{11}$

One very interesting form of co-operation of the same kind-recreative, if not exactly intellectual-is that for providing a holiday in the country, or what the English call "co-operative holidays." This aims at procuring for people who could not otherwise afford it the means of passing some days of vacation in the country or at the seaside. With this object, houses are rented, or even built in suitable situations and the expenses of board and travelling are fixed at cost price. To be accurate, these efforts, as they are worked at present, are really more philanthropic ventures than genuine co-operative movements; the initiative and the direction do not come from those most to be benefited. But there is no reason why they should not develop on more strictly cooperative lines, or they might be attached to some co-operative consumers' society from henceforward. The English Association has already thirteen holiday resorts in England, Scotland, Germany, Switzerland, and France, some of which

11 We have referred in a previous note to co-operative moving picture theatres in the United States.

In Greater New York the three co-operative evening schools are organized, financed, and controlled by the adolescent and adult students, These boys and girls, men and women, hire their own teachers, rent their own class-rooms, and publish their own little periodicals. 
are magnificently fitted up, where visitors are received, on terms somewhat variable, but always very moderate.

We might point to analogous works in France. There are five vacation places organized, at the seaside or in the mountains.

Co-operative holidays are obviously only possible for those persons who can get some days' vacation. But if the majority of clerks enjoy this permission there are still very few workmen who can claim the privilege, although certainly no social class has more need of it. However, it is certain that this demand will soon be enforced, as well as that for the weekly half-holiday.

Cercles (clubs) may be considered as co-operative associations, in the sense that the members are also beneficiaries; but as these clubs are worked on contributions, not shares, they come rather under the category of mutual aid. It is a general rule among the societics affiliated to the National Co-operative Federation that each co-operative society has its club attached to the store, with dining rooms (nonalcoholic liquors if possible), rooms for games (not for money stakes), rooms for reading and discussion, \&c. This is a method of establishing daily intercourse among the members; this intercourse induces closer and more cordial relations than any which might result from the annual or halfyearly general meetings, and, above all, keeps alive a certain social ideal.

\section{(8) Co-operative Insurance.}

There is one need which, while not belonging to a material order, such as food and lodging, is none the less pressing; it is that of insurance. Of course it is not in our power to guarantee against the risks of life, but it is at least possible to make good their pecuniary consequences, by means of insurance. We know that this marvellous institution consists in consolidating the largest number of persons 
possible in the expectation of a certain risk in such a way that when it strikes one of them the blow so infinitely divided will only inflict very slight injury to each individual.

Every insurance enterprise is thus co-operative in the larger sense of the word. Nevertheless, the word is not used when the insurance is organized as a capitalist enterprise, as companies with fixed premiums as they are called, because the shareholders have no dealings whatsoever with the insured, except to draw enormous dividends at their expense. Neither must we confuse mutual with co-operative insurance. The first is formed without capital, makes no profits, reccives nothing but contributions, and can only indemnify risks up to the limits of these contributions. The second is formed with a social capital, makes profits, and undertrkes to pay stipulated indemnities in full. The co-operative insurance company bears much more resemblance to an ordinary insurance company with fixed premiums, with the essential difference that the profits, instead of being distributed among the shareholders in proportion to their shares, are divided among the insured co-operators, in proportion to the premiums paid by them.* 12

The genuinely co-operative insurance societies are very rare, doubtless on account of the great difficulty they would meet with in collecting the large capital which is indispensable to their functions; and where there is no such cap-

* Author's Note. There are still some insurance companies which resemble the co-operative system, inasmuch as they give their clients a part of the profits, which may go towards reducing their premium.

12 The excellent insurance plan of the Jewish Workmen's Circle is on the mutual benefit model. The United States does not yet have any co-operative insurance against sickness, accident, or death organized on the Rochdale plan.

Among the farmers of certain parts of the country, however, there are insurance companies for the protection of investment in buildings and other property; insurance against fire, lightning, hail, windstorm, etc. Some of the best known of these, among the Jewish farmers, instead of rebating surplus-savings directly to the members, deduct such savings from the assessment levied the following year. 
ital we must fall back on mutual insurance. It is true that in France several of the largest insurance societies at fixed premiums began with a purely guaranteed capital, that is to say the full payment of the shares has never been demanded. But even under this form of guaranteed capital, though the money need not be paid up, there is still a pecuniary responsibility to be assumed which is sufficient to scare away any subscribers from among the working classes.

But why should we create special co-operative insurance associations? Would it not be much simpler if the consumer's' societies would add this service to those which they already excrcise? We know that when these societies reach a certain point they have superfluous capital at their disposal; well, then, a co-operative insurance service would be a very profitable outlet for these reserve funds. In England, the Co-operative Insurance Socicty was founded in $186 \%$. It insures against fire, accident, dishonesty of employés, and the breaking of windows, and, above all, does a life insurance business for more than $1,100,000$ co-operators, and receives $£ 312,000$ in premiums. It is the consumers' co-operative societies which have supplied nearly all the capital (at least 5 shares of $\mathfrak{f} 1$ for each affiliated socicty, of which only $\mathfrak{f l}$ is paid up), and which constitute the whole of its clientèle. But this joint-stock company is undoubtedly destined to be soon absorbed by the English Wholesale Socicty, which opened an insurance department in $1913,{ }^{13}$ which will probably grow as quickly as their bank. They might go much further. It is reckoned that the working-class in England

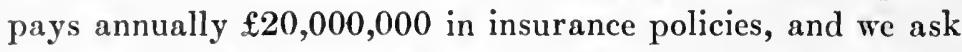
why should this enormous sum not be paid into co-operative societies? The profits, instead of enriching various shareholders, would be given back to the people insured.

13 The Co-operative Insurance Society was taken over by the English and Scottish Wholesale Socicty in 1913. 


\section{CONSUMERS' CO-OPERATIVE SOCIETIES}

This brings us to the end of our review of the various forms of consumers' societies. We leave on one side two classes of co-operative societies which are, nevertheless, closely related -societies for the purchase of raw materials and implements, and the credit societies and rural banks. Both these types are very numerous in agriculture, but they are still very rare in industry. Botl kinds of society provide the supply of very urgent requirements, and by the same means, i. e., by association of those interested; but here we get into the domain of production rather than of consumption. Fertilizers and seeds purchased by agricultural syndicates, and capital loaned by rural banks, have clearly no other object than to serve agricultural production. Therefore, these special types should be studied in a treatise on co-operative production. ${ }^{14}$

14 In many of the larger cities in the United States and even in some of the towns, retail merchants are organized for collective buying. This, too, is producers' co-operation. We also have credit unions organized among small business men. 
As soon as co-operative movement in any country has reached a certain stage of development the co-operative societies begin to form federations, as do other types of associations, such as mutual aid societies and trade unions.

There are two aspects of these federations, one social and the other commercial; one to develop the spirit of solidarity among the societies and to guide the co-operative movement; the other to bulk purchases, and, if possible, organize production: and though these two aspects can be united in one organization (as in Switzerland and some other countries) the work is better divided if they remain distinct, like two houses in a parliamentary government. In any case, it is better to consider them separately. In France, the Cooperative Federation and the Wholesale Socicty are two distinct organizations with separate offices, and even distinct committees, but it is significant that the two committees are formed of the same persons.

\section{Section 1.-Co-operative Unions}

These, as we have said, are formed with the sole object of developing the spirit of solidarity among the societies, of making them conscious of their place and their power; to get from them and to furnish to them statistical, legal, and conomic information, to call periodical congresses, to publish periodicals and books, to organize all forms of propaganda, and, if possible, programs of common action, to divide into districts and quarters the area of each society so 


\section{CONSUMERS' CO-OPERATIVE SOCIETIES}

as to avoid overlapping, and its resultant competition-in a word to exercise the functions of a government whose authority, it is needless to say, is purely moral.

Their function is very important, at least where co-operators are well organized and disciplined, and are not divided by bitter political and religious feuds. The services which the Co-operative Union at Manchester has rendered to British co-operation since its creation in 1869 are inestimable. Of Italy and Switzerland it may be said that their co-operative history dates from the formation of their Co-operative Union (1886 in Italy, 1890 in Switzerland). The British Co-operative Union embraces 1,300 societies with $4,109,843$ members, that is, almost all British co-operators. In Switzerland the Union embraces 400 societies out of the total of 400, though it is true that some of them are not consumers' societies. The new Union of German Consumers' Societies (created in 1902) numbers 1,300 societies with more than 2,800,000 members. ${ }^{1}$

These Unions each year gain a fairly large number of new societies, which wish to profit by their advice, but it is too often the case that when the societies become strong they seek to show their independence by leaving the Union, and attempt to prove that they have grown sufficiently to stand on their own fect.* Even if this were true they ought to real-

1 In 1921 there were more than 300 societies affiliated with The Cooperative League. These were all consumers' societies. There are hundreds of other societies which doubtless would have joined were it not for the fact that they were already affiliated with other federations or unions which gave them the advice and guidance that The Co-operative League offers its members. Most of the Jewish societies have been affliated with the Federation of Jewish Co-operative Societies (recently merged with The Co-operative League). Hundreds of farmers' societies are affiliated with the Farmers' Educational and Cooperative Union, the most progressive of the organizations among the farmers.

* Author's Note. This is so in one of the biggest societies in Paris, the Bellevilloise, but is not peculiar to France. Big societies abroad sometimes do the same. Thus the biggest Italian society, the Unione Co-operativa of Milan, is not a member of the Italian National League. 
ize that it is precisely because they are strong and rich that they should be a support to the Union and to the small societies which remain faithful to it, and that in withdrawing their support they commit a grave sin against the duty of solidarity.

In France, the old Unions which have since disappeared, did much, in spite of their weakness, for the development of the co-operative movement.

The old Union Coopératize," which was founded by M. de Boyre, organized numerous congresses, published a bulletin and, after 1893, a year-book. It collected the first statistics of French co-operation; it organized the consumers' cooperative section in the two Paris exhibitions of 1889 and 1900 , and in the majority of foreign exhibitions; it took part in the formation of the International Co-operative Alliance; directly, or by means of its legal committee, it gave advice on countless matters. It took part in the drawing up of many sets of rules, and defended a whole host of societies against the exactions of the Government. When it is realized that its revenues hardly reached $\mathfrak{f 6 0 0}$ a year it is wonderful that it was able to do so much with so little money.

The existing Fédération Nationale will do better still; the keen co-operators who direct its policy do not neglect anything that can help in the economic and moral development of co-operation in France. Its activities include the publication of a newspaper and a year-book, the organization of periodical conferences and annual congresses, the appointment of delegations to the international congresses, and the relations with the Government. The war, which might have paralysed its activities, provided it, on the contrary, with incexpected opportunities of extenaing its influence. Tho new Fédération Nationale des Coopératives de Consommation was formed by the fusion of two earlier federations, the "Union" and the "Bourse," which each had 400 members (see above, page 4i3). The Fédération includes a few more 


\section{CONSUMERS' CO-OPERATIVE SOCIETIES}

societies than the totals of the two earlier federations added together. The amalgamation caused about 100 societies to leave the earlier bodies, but attracted between 200 and 300 new members. This caused a small gain, but the membership is still far from what might be expected. Since the war progress has been made. The figures for 1921 are: societies belonging to the Union, 2,100 (out of 4,000); members, about 1,000,000 (out of 1,300,000).

In Belgium, political differences have prevented the formation of strong unions. In Germany, there were ten co-operative federations, but they were as mixed up as were the States of the old German Confederation. All the forms of co-operative association-consumption, production, credit, building. \&c.-are found mixed up pell-mell, and as they have opposite ideals they injure more than they help each other. We mentioned (page 45) that a schism had occurred in the most important of these federations, that of Berlin, founded by Schulze Delitzsch, and that a new union formed of consumers' societies only, and more especially of working-class socictics, had been constituted at Hamburg. But this does not embrace all the German consumers' societies.

All these unions are formed on a "parliamentary" model, yet with the difference that their "parliament," which is a congress, meets only once a year for a few days. Between the meetings they are represented by a permanent committee of delegates, elected by the societies for a certain number of years.*

*Author's Note. The "Fédération Nationale" is governed by a Central Committee elected at the annual congress of the societies. Members of this committee must be practising co-operators, i. e., they must belong to a consumers' society, and make a certain minimum of purchases. The committee meets every month. There are three secretaries, who are the executive officers.

Besides the Central Committee there are special commitees which benefit from the presence of a number of specialists in the various branches of work.

Thus the secretary of the Technical Bureau for practical and eco- 
The parliaments and committecs of these unions have only moral authority over the societies. Would it not be possible to give them effective authority? It would, if the union became a national society, of which the local societies were merely branches. 'This is the ambitious plan which Mr. J. C. Gray, the late General Secretary of the British Co-operative Union, proposed at the inaugural session of the Congress, held at Birmingham, in 1906. Not only would the local societies lose their autonomy, they would only have the disposal of half their profits, the other half would be paid into the exchequer of the national co-operative socicty, which would use it as seemed best to it in the interests of co-operation. The committee of the national co-operative society, which would include the Wholesale Society would be elected by all the societies, on a basis which would have to be determined.

This project has little chance of being realized for a long time, at least in France. Not only are the local societies very jealous of their independence, and disinclined to allow themselves to be absorbed in this collective organization and to give it half their profits, but even if they consented, it is feared that half their members would leave them.

Obviously the work of these unions cannot be carried on without expenditure, and therefore they need a fund. This fund is furnished by the subscriptions of the societies, so that the development of the union, and therefore of the

nomic questions was formerly M. Albert Thomas, later Under-Secretary of State for Munitions in the War Office. By a curious coineidence one of the directors of the "Féderation Nationale Co-opérative," M. Auguste Müller, held high office in the German Ministry of Food.

The Legal Bureau deals with the numerous legal questions sent in by the soeieties.

The Educational Committee deals with clubs, excursions, and, above all, the education of children.

Besides the National Federation, France is divided into regional federations, 17 in number, whose delegates meet in Paris every month. 
co-operative movement itself, depends more or less on the willingness with which the societies pay their contributions.

The constitution of the British Co-operative Union is rather complicated. It is governed by a Central Board of 67 members, elected by regional sections, which meets only twice a year. Next, there is a smaller committee, the United Board, formed of 14 members, which meets more often; and, above all, a general Secretary, who is, in fact, the head of the organization, the head offices of which are at Manchester.

The expenses of these unions generally include the salary of at least one permanent secretary, and often other employés, the rent of offices for the meetings of the committees, and the expenses of correspondence and publishing. In Britain these expenses amount to a large sum. The subscriptions of the affiliated societies, fixed at $1 \mathrm{~d}$. per member, ${ }^{2}$ though this rate is, in fact, often exceeded, produce more than $£ 16,000$ a year. Special donations and receipts from the sales of publications raise this to $£ 20,000$.

In France, the turnover is taken as the basis of contribution, rather than the number of members, as it is more easily ascertained. The basis taken has been five centimes per 100 francs turnover, of which one and one half centimes is for the regional federations. In fact, the average purchases per member being 800 francs, that represents $800 \times \frac{5}{100}=40$ centimes. The total comes to Fr. 380,000 or $\mathfrak{E} 7,400$ in present currency, including the subscription from the Wholesale Society.

\section{Section 2.-Purchasing Federations}

These have a purely economic object-the purchasing in

2 According to Professor Hall of the British Co-operative Union, this rate has now been increased to $2 \mathrm{~d}$. per member, producing 35,000 pounds annually, 
common of the goods necessary for supplying the affiliated societies.

The federation of co-operative societies for purchasing in common has the following advantages:- ${ }^{\mathbf{3}}$

(1) It reduces the purchase price to each society, because the purchases are made in large quantities. It is clear that just as the grouping of individuals to make purchases in common enables them to reduce the price, so also does the grouping of societies. The federation is only a co-operative society of co-operative societies.

(2) It facilitates the starting of small societies. It is obvious that the initial stage of any undertaking is the most difficult, and it is particularly so in co-operation. A young society which has only a few members and small capital, no experience of business, and which is the object of the hostility of all traders of the district, runs a great risk of dying in infancy. The world laments the rate of infant mortality for about one-quarter of the babies born die during the year which follows their birth. Well, the rate of mortality among infant co-operative socicties is as pitiable (see later, Chapter xir).

But the existence of a purchasing federation is enough to alter this sad state of affairs, because it gives small societies the same terms as big ones. It sells them the goods they need at the same price. Not only does it give them the benefit of the same prices as their older sister societies pay, but it saves them from the blunderings and blind gropings common to first attempts, by giving them the necessary advice and sending them all they need on demand. Thus a society which is being started need not have any specialists

3 All the following advantages accrue to societics affilinted with wholesale co-opcratives in the United States except $\$ 5$ (manufacturing of goods by the co-operators themselves). Our co-operative wholesales, - with the exception of the Co-operatlve Central) Exchange of Superior, Wisconsin, which has a biscuit works, - have scarcely progressed to this point. 
among its members. It need only write to the federation saying, "We are such-and-such a society, send us all we shall need."

As for the big societies-which sometimes scorn to belong to federations, saying to themselves that they are strong enough to get the same terms from traders-they must understand that though they may make no money gain (which generally is not so) yet their development and their very existence are bound up with that of their little sisters in the great co-operative family.

(3) It stops illegal commissions (commonly called pots de vin), and so raises the moral tone of co-operative trade and saves the societies from a vice that is already too common in business. When purchases are made through a wholesale society, the members of the committee of a society have no direct relations with the suppliers. It may perhaps be said that it is the managers of the wholesale society who will get the illegal commissions. Perhaps, but as they are better watched (to put the matter on its lowest grounds) and as they are only a few persons instead of a few thousands, the evil will be lessened.

(4) It prevents any boycotting by wholesalers and manufacturers. It sometimes happens that the wholesalers of a district make an agreement to refuse to sell to a co-operative society, in the hopes of killing it. This has been the case more than once in England, Sweden, \&c. (See Chapter XII, The Conflict between Co-operative Societies and Traders.) This form of tactics becomes useless when the co-operative societies are backed by a federation which undertakes to supply them with all they need. What does it then matter to them if the local merchants refuse to supply them? They can afford to laugh at their opponents. In this way small co-operative societies have been able to bring their adversaries to their knees, for not only has the English Wholesale 
Society supported them, but it has voted $£ 40,000$ as a kind of "war chest" to fight such boycotts as may come in the future.

(5) It enables goods to be manufactured by the co-operative societies. It is not easy for a single co-operative society to set up a boot factory, a soap works, \& $\mathrm{c}_{r}$, for itself, because it is not large enough to guarantee sufficient sales, unless the society has a very large number of members, which few have.

On the other hand, when a purchasing federation bulks the orders of hundreds of societies it can erect factories with the certainty of success, because it knows beforehand what sales it can count on. Thus the federation of English societies, the Co-operative IVholesale Society of Manchester, has been able to build flour mills, soap works, boot factories, and jam factories, which produced goods to the value of $£ 12,000,000$ in 1915 .*

What societies by themselves could possibly attempt similar enterprises? And yet it is recognized that it is only by production that co-operation can change the present economic system. So, federation is necessary, because he who seeks the end must seek the means.

(6) It makes possible the organization of works of general utility, and if it does not do educative work, as that is more the business of Unions, it renders at least such services as banking and insurance. If such work be left to the separate societies to organize, the dissipation of energy will prevent anything being done.

There are three degrees in the grouping of societies for purchasing, indeed, one may say three stages.

(1) The first is the Agcncy. ${ }^{4}$ The agency confines its ac-

* $\Lambda$ uthor's Note. In 1919 the figure rose to $\mathfrak{2 6 , 0 0 0 , 0 0 0}$ due largely to the rise in prices.

4 We do not know of American co-opcrative societies which have established anything corresponding to this agency, nlthough we do 
tivities to obtaining quotations from wholesalers for the societies, and collecting and transmitting orders to the wholesalers.

This first is the simplest form, because no store is needed, but merely an office and no capital is required, as the only expenses are the small ones of advertisement and correspondence. But if the expenses are very low the services it can render are very limited. It can hardly realize any of the great advantages which we have mentioned above; it can only obtain some reduction in price and guarantee of quality.

Still, it is wise to begin by this unambitious form of organization.

(2) The second is the Syndicate, which is not, like the first, merely an office for the transmission of orders, but does commission work. It bulks the orders of the societies and buys from the wholesalers on their account. This is the method adopted by most agricultural societies in dealing in seeds and manures. Sometimes, if the market is favourable, the Syndicate buys on its own account.

This second form is stronger than the first, but it can hardly do without capital, or, at least, guarantors, if it is to deal directly with wholesalers.

(3) The third is the Wholesale Society. This is the true co-operative society of co-operative societies, such as we were discussing a few pages back. It buys direct from the producers, or itself manufactures all that is necessary to supply its nembers, and sells to them at wholesale prices, or, at least, at very slightly increased prices, to allow a margin for emergencies. In any case, if there be profits they are divided, not among the shareholding but among the purchas-

know of localities where such Agencies might profitably be estáblished. Corresponding to the French Syndicate is what many American cooperators know as the Buying Agency. 
ing socicties; thus, the same principle is applied to the societies, as they themselves apply to their members.

For this, not only is it necessary to have a large capital, but huge stores and whole battalions of employés also. But it is possible to obtain an indefinite degree of power, as in England, where it is feared that the Wholesale Society may come to reign almost despotically over all English co-operation.

The Rochdale Pioneers-who cannot be too much admired -foresaw everything, and created in their own society a wholesale store for helping others; but it was not until 1864 that the real wholesale society, the C. W. S., was started. It began with a membership of fifty societies, and a capital

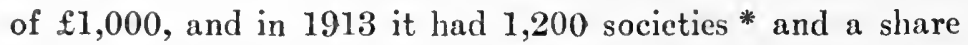

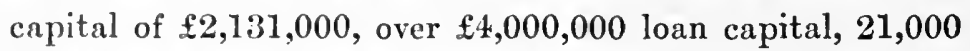
clerks or workers, huge warehouses where it does business, and more than 100 factories where it produces $£ 9,000,000$ worth of goods of every variety. This is the pre-war figures for the English Wholesale, but the post-war figures enables us to measure the progress made in 1920:

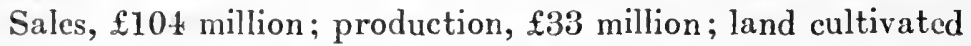
in England, 32,500 acres. The enormous increase in the C. W. S. funds is specially remarkable. It imports, partly in its own ships, $+\underset{+}{+} 8,000,000$ worth of the products

*Author's Note. That is to say, almost all the English societies. The Scottish Co-operative Wholesale Society, of Glasgow, includes 261. Scottish societies.

†Author's Note. In 1921, however, there was a notable decrease: only 80 million sales, 26 million production.

$\ddagger$ Author's Note. To import the goods which it consumes it commissioned a fleet of six ships, which sailed under the house flag of the C. W. S. But it was found that the ships cost more than transport by the ordinary shipping companies, so four of the ships were sold to a big railway company having ships of its own. Only two ships were kept, which trade between Manchester and Rouen. This is a step backward and an abandonment of co-operative principles. Besides, the financial loss was perhaps more than balanced by the added prestige.

One day is set apart each year (generally in October) for the sale of raisins and other dried fruits, which the C. W. S. buys in Greece 


\section{CONSUMERS' CO-OPERATIVE SOCIETIES}

of all countries; it bought at the price of $\$ 50,000$ a large piece of land beside the Manchester Ship Canal to make docks. It has three establishments in Denmark (where it buys $£ 4,000,000$ worth of butter and bacon) one in the United States, one in Germany (at Hamburg), one in Sweden, two in France (at Rouen and Calais), one in Spain, one in Canada, and one in Australia. Besides these establishments for purchasing abroad, it has a tallow factory in Australia, and tea plantations in Ceylon and India of 40,000 acres. In England itself it has six estates, where it grows strawberries and tomatoes, and where it has set up a convalescent home for its members and their families. It will soon own coal mines. During the war it received large orders for food and clothing from the English Government, and even from the Russian Government (notably for boots).

The capital of the Wholesale is furnished partly by the shares which all the affiliated societies must subscribe for at the rate of fifteen $\mathfrak{f l}$ shares for every ten members, and partly by loans from the societies.

It has a bank to regulate its huge operations, which does all the usual banking business of discounting, taking deposits, giving advances, \&c., and thanks to which the smallest society can obtain loans at lower rates than the largest capitalists can get from the Bank of England. During the crisis of 190\%, when the Bank of England raised its discount rate to 7 per cent., the Wholesale Bank continued to lend at $31 / 2$ per cent. A short time ago the Scottish C. W. S. lent $\$ 500,000$ to the municipality of Glasgow.*

We have already mentioned that it has taken up insurance in all its forms.

It does not try to make profits from its immense business,

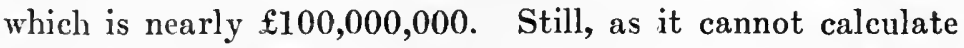
the exact prices which should be charged it works on a small and Asia Minor. On this one day its sales reach or exceed $£ 160,000$.

* Author's Note. The turnover of the bank in 1920 was 155 million pounds. 
margin which realized about $£ 1,200,000$ a year in 1916, but this margin of profit decreased greatly in 1917, and vanished altogether in $1921 .^{5}$

Its strength is so great that there is a fear that it will be abused, and co-operation turned into a big centralized bureaucratic machine. We shall consider this matter later on (see Chapter XIV).

Still, there remains a margin for development, because it is far from selling to the co-operative societies everything which they sell to their members. Its total sales can still increase greatly * when all the societies make it a rule to

5 During 1921 the C. W. S. lost 1,416,000 pounds. The loss is attributed to strikes, unemployment, depreciation in value of goods on hand. The reserve fund was ample to cover the loss.

*Author's Note. It must not be thought tliat the sales of the Wholesale can ever equal the sales of the socicties because:-

(1) Retail prices are always from 15 per cent. to 20 per cent. above wholesale prices.

(2) The distributive societies themselves produce part of the things they consume, notably bread, which is a big item, or they buy from the co-operative productive societies, as we shall see later. These two, added together, represent about 30 per cent. of the sales.

The margin for extension of the purchases from the wholesale is less than appears. Still it is large, and is still larger in other countries. The following table shows the proportion of sales by societies and the wholesale society in some countries. The relation between the two figures is a sure index of the degree of co-operative organization.

In this comparison the date of the establishment of the wholesale society must be taken into account, but the development of the wholesale society is not dependent only upon its age. This is shown in the following table (the figures are for 1914):-

\section{Head Office}

and Date of

Foundation.

\begin{tabular}{|c|c|c|c|}
\hline $\begin{array}{l}\text { and Date of } \\
\text { Foundation. }\end{array}$ & $\begin{array}{l}\text { Sales of } \\
\text { Wholesales. }\end{array}$ & $\begin{array}{c}\text { Sales of } \\
\text { Retail Stores. }\end{array}$ & Proportion. \\
\hline Manchester (1864) & 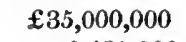 & $£ 87,900,000$ & $\ldots 50 \%$ \\
\hline Glasgow (1868) & $\mathbf{9 , 4 3 5 , 0 0 0}$ & $18,000,000$ & $52 \%$ \\
\hline Copenhagen (1888) & $3,920,000$ & $6,000,000$ & $65 \%$ \\
\hline Bâle $(1892) \ldots \ldots$ & $1,840,000$ & $5,760,000$ & $32 \%$ \\
\hline Hamburg (1894) & $7,880,000$ & $26,360,000$ & ... $30 \%$ \\
\hline Moscow (1898) & $1,120,000$ & $32,000,000$ & $3.5 \%$ \\
\hline Helsingfors (1904) & 440,000 & $12,840,000$ & $3.5 \%$ \\
\hline Paris (1907). & $1,040,000$ & $2,520,000$ & $41 \%$ \\
\hline
\end{tabular}

Today all these figures are doubled, and in some countries quadrupled. 


\section{CONSUMERS' CO-OPERATIVE SOCIETIES}

supply themselves through the Wholesale only. It is certain that they would be rewarded for their fidelity by an increase in their profits.

There is nowhere in the whole economic order anything comparable to the Wholesale Society, except the trusts and cartels. There are, however, notable resemblances between these two organizations. The federation of consumers' societies for producing are really consumers' trusts, and will perhaps have the salutary effect of preventing the public and the markets from being delivered defenceless into the hands of the great federated capitalists. ${ }^{6}$

It is true that the mammoth Co-operative Wholesale Society is unique in the world. Still, in Glasgow (for Scotland) and in Hamburg (for Germany) there are already wholesale societies which do very large businesses.

The Co-operative Wholesale Society of Glasgow, although much smaller than that of Manchester, judging by turnover, is not behind it in enterprise or ambition. It has a large number of factories, whose production reaches $£ 6,000,000$.

The Wholesale Society at Hamburg has served as a rallying point for the workers' societies which broke off from the General Union at Berlin after the Congress at Kreuznach in 1902. It is probable that the Hamburg federation will develop considerably, especially as the Germans are past masters in organization and federation.

If its progress from its birth in 1894 to 1914 be compared with that of the English Wholesale Society for the corresponding twenty years (1864 to 1884) it is seen that it is even more rapid, for in the twentieth year of its life the Wholesale of Manchester only did a business of $£ 4,675,000$,

But these enormous increases mean nothing, on account of the depreciation of the mark, crown, rouble, etc. For the two British wholesales the increase, though large, hardly exceeds the rise in prices. The same is true of France. But for Switzerland the increase is far greater than the rise in prices.

6 Such powerful wholesales are needed in the United States to combat the highly organized chain-store corporations. 
while the Hamburg Society at the same age did nearly $\mathfrak{1 8 , -}$ 000,000 .

It is noticeable that Belgium, in spite of its great cooperative activity, does not appear in the list. There is however, a Belgian federation, created in 1900, but which has only a small number of affiliated societies, and does but a small trade.

We in France are far behind. In 1887 the Central Committee, which has now disappeared, had succeeded with much trouble in establishing a wholesale society. It did not begin badly, since it had reached a turnover of $\mathfrak{1 0 0 , 0 0 0}$ in 1892, but it failed, for various reasons, too long to set out here. This check retarded the co-operative movement a great deal. The first purchasing federation was established in 1885, at the same time as the "Union Coopérative" under the humble name of the "Chambre Économique" (Economic Office). In 1888, the Chambre Économique took the title of "Fédération Nationale des Sociétés Coopératives" (the National Federation of Co-operative Societies), and acted at first as a purchasing agency. That is to say, it confined itself to buying to the order of the societics, many of which were slow in paying. It made the mistake of trying to form itself too soon into a real wholesale society with its offices at Charenton. The big Parisian societies abandoned it, alleging that they could buy better directly than through the Federation, and because of personal quarrels. The bad organization of the Federation justified these desertions to some extent. The Wholesale Society failed in 1895, leaving big losses to be made good by the societies which had remained loyal to it and the Central Committee.

Later, two distinct and even rival organizations were formed:-

(a) The Office Coopératif" (the Co-operative Office), an annex of the Co-operative Union, was at first a simple agrency, then a syndicate for grouping orders, and was at 
last transformed into the "Coopérative de gros" (Co-operative Wholesale Society). It was formed in 1900, and had not reached a turnover of $£ 80,000$ in 1912 , when it was amalgamated with the socialist federation.

(b) The Wholesale Society (Magasin de gros) of the Socialist Bank, thanks to the stronger feeling of loyalty which inspires societies engaged in a class war, made more rapid progress. Formed in 1906, its turnover was $£ 400,000$ when the amalgamation took place in 1912 .

Today, the two rival federations are united in the Wholesale Society situated at 29, Boulevard Bouddon, Paris. The great increase in turnover which was expected from this amalgamation was not realized immediately, and the Wholesale passed through some anxious moments. This state of things was, however, inevitable, considering its very small capital, $£ 3,520$. If the society had to deal with a trade of $£ 400,000$ a year it would therefore have been necessary for it to turn over its capital one hundred and thirty times in the year, or once every three days! The Wholesale Society was obliged to obtain its working capital from deposits ( $£ 140,000)$, and this created a very difficult situation, indeed a highly dangerous one for an ordinary bank. Happily, the depositors in the Wholesale Society were either co-operative societies or trade unions which wished to help, not to embarrass it. Also, the C. W. S. generously came to the rescue of its young sister by lending it $£ 24,000$. Meanwhile, the war broke out and did on the whole more good than harm, for the local co-operative crisis was overwhelmed and almost forgotten in this great general crisis. After the war the Union has emerged from this test stronger than before. The sales are now more than $£ 8,000,000$.

As regards production the French Wholesale Society had only preserve and boot factories, doing between them business to the value of $\mathfrak{f} 600,000 .^{7}$

7 By 1921 the French Wholesale Society is also manufacturing under- 
There are also territorial district associations which have no right of sale or purchase, and whose one function is to send delegates to the quarterly meetings. Perhaps it would have been wise in a country with such varying forms of productive activity as France-which in spite of its apparent unity, has kept distinct local characteristics-to have left a certain amount of independence to the district federations. As it is, there is a tendency to revive them in the form of agencies of the Wholesale Society.

The causes which have made federations of societies, either for purchasing or simply for mutual defence, so difficult to form and so slow to progress, are worthy of careful study. It seems certain that the national temperament of France, which is not so much individualist as particularist, is largely responsible for it. There is also the question of vanity, which makes the members of a little society unwilling to give up their autonomy, and which makes the members of the committee unwilling to give up any of their power of control or of purchasing; they wish to deal directly with the wholesalers. Worst of all, there is often the fear that certain abuses will be abolished to which they cling, and on which they live, such as illicit commissions from suppliers, which would have to be given up if orders passed through a central office or wholesale society. Some things which happened lately in England have shown us that English societies themselves were not wholly free from this plague, which has killed some French societies and contaminated many others. ${ }^{8}$

clothing, chocolate, and operating a coffee roastery and a sawmill. The following figures show how rapidly the business of the Society is growing.

1914-15

1920-21

Affiliated Share Cap.

Turnover

Societies

425

1700

\& Reserve

$£ 11,780$

$£ 200,000$

$£ 548,800$

$£ 8,250,000$

(Figures quoted from People's Year Book of the C. W. S. and the S. C. W. S.)

${ }^{8}$ In such a large country as the United States there will, of course, have to be District Wholesales before wholesaling on a national scale 


\section{CONSUMERS' CO-OPERATIVE SOCIETIES}

Above the national federations there is room for an International Federation; in fact, such exists at least in embryo, under the name of the International Co-operative Alliance. One of its first initiators was M. de Boyve, who suggested it at the British Co-operative Congress at Plymouth in 1886. It was not officially formed, however, until 1895, when its first Congress was held in London. Since then it has met every three years-at Paris, the Hague, Budapest, Cremona, Hamburg, and Glasgow-and its reports form a valuable contribution to the study of the co-uperative movement throughout the world. It has published a bibliography of co-operative literature in all languages, und publishes a monthly bulletin in English, French, and German, which was continued as well as possible in spite of the war.

The Alliance is governed by a permanent committee, which formerly filled up its vacancies by co-option; but the members are now elected by the federations of their respective countries (except for M. de Boyve, who was given the title of perpetual honorary secretary, as the one still living founder of the Alliance.)* The number of members which each country has a right to elect is settled by the amount of its subscriptions (a contribution of $£ 10$ gives a right to elect one member, and $£ 600$ to elect seven members, which number may not be exceeded). Seven is the number of British representatives. Germany and France have four each; Switzerland and Hungary three each; Austria, Russia, Finland, Sweden, Denmark, Holland, and Belgium two each; Italy, Roumania, Serbia, and Norway one each. $\dagger$ An embar.rassing question which arose before the war is that of recog-

is attempted. Meanwhile, although we find all these factors which would restrict federations of societies for purchasing, the slow development of co-operative wholesales among American societies is principally due to the fact that there are few sections of the country sufficiently covered with co-operative stores to warrant such federations.

* Author's Note. There are also honorary members named directly by the Central Committee.

†Author's Note. Since the Congress of Basel in 1921, the United 
nizing nationalities which claim independent representation. As is seen above, this was granted to Finland, but refused to Bohemia and Poland which aroused strong protests. Henceforth they will certainly get direct representation in the Alliance, but conflicts may be looked for about the numerous republics which will issue from the dismemberment of Russia. This electoral system, which seems to us more fiscal than democratic, has not failed to provoke criticism, yet it is the socialists who have supported it most strongly.

The Alliance includes all forms of co-operative association, i. e., consumption, production, credit, and agriculture; but the first tends more and more to predominate.

Originally, however, this association had for its chief object the safeguarding of the rights of producers, to the end that they should not be handed over to the despotic government of the consumers, as was foreshadowed by the great growth in power of the Wholesale Society; it was a sort of individualist revolt against what might be called co-operative collectivism.

To effect this, the Alliance advocated, if not self-governing workshops, at least a share in the profits for all workers in the services of distributive societies engaged in production. Article 1 of the Laws (now revised) said, "The Alliance has for its aim ... to hasten, by all the means of propaganda at its disposal, the moment when all associations called co-operative shall organize in favour of sharing the profits with all the employés without exception." But this early ideal was bit by bit thrust aside, as profit-sharing had not succeeded to any great extent, and, as, moreover, the socialist element, which increased on the committee and in the congresses of the Alliance, was absolutely opposed to it.

States and Czecho-Slovakia have representatives to the Central Committee of the Alliance. 


\section{2}

CONSUMERS' CO-OPERATIVE SOCIETIES

The Alliance has rallied to its support today all the big federations of all countries, besides a large number of individual societies. Britain alone supplies about half of the subscriptions; but Germany and Austria were rapidly increasing their subscriptions and influence, and before the war it was seen that ere long the control of the Alliance would be transferred from London to Hamburg.

The program of the Alliance today, as recently laid down by its president, Sir William Maxwell, is :-

(1) 'The moral and educative aim of putting the co-operators of different countries in touch with one another so that they can teach each other and help the co-operative movement by their union.

(2) The practical and commercial object of bringing cooperative societies in different countries into business relations so that the products of those which produce may find outlets in those which only distribute, and that the latter on their side can procure their goods under the best possible conditions. An international wholesale society has been projected.

(3) It has the yet higher aim of establishing peace between nations. At the Glasgow Congress (1913), notably, a solemn resolution against the folly of armaments was carried. The German delegate, von Elm, supported the motion, and declared, amid applause, that in Germany all co-operators to the number of four million eight hundred thousand heads of families in 80,555 societies strongly demanded peace. "I know," he added, "that the rulers of the world pay little attention to the wishes of co-operators, but it will not always be thus." If, in fact, as we believe, wars are caused above all by economic causes, and are continued in the struggle for profit would it be in vain to hope that cooperation which has for its ideal the abolition of profit, could establish peace?

Still, we must admit that of these three aims only the first 
has been realized to any degree. The realization of the second is made difficult by the fact that the agricultural and credit societies, and even the productive societies, frightened by the imperialist ambitions of the consumers' societies, are gradually leaving the Alliance.*

As for the third ain, one can hardly hope to see its accomplishment during the next generation. Nevertheless, the International Co-operative Alliance sueceeded in living through the war, and its bulletin, published in three langunges, English, French, and German, was a link between co-operators of the belligerent countries. ${ }^{9}$

* Author's Note. For a detailed history of this institution see our prochure on the "International Co-operative Alliance," which has been translated into English.

\& A national union of the co-operative societies of the United States was represented by duly elected delegates for the first time at the Congress of the International Alliance held in Basle, Switzerland, in 1921, by Dr. and Mrs. James P. Warbasse. It was at this Congress, also, that the co-operators of the belligerent countries of the Great War were once more united in genuine concord. The seating of delegates from Russia was discussed at length and warmly, for it had not yet been definitely established that the Movement in that country was entirely free from government control. Finally, however, the two delegates were given seats. The one other outstanding event of the occasion was the organization of the International Women's Co-operative Committee, of which Frau Emy Freundlich of Austria is Chairman.

Since this Congress there have been committees at work studying the entire question of International Trading, the formation of an International Wholesale, and the organization of an International Co-operative Bank. These are vexing problems in any event; they are made more vexing by the fluctuations in the rates of exehange between various countries, and by the fact that economic resourees in the co-operintive movement are not at all evenly distributed between the various European countries: the Wholesales in England and Scotland are far and away the more powerful of all the wholesales. Moreover, none of these problems can be solved separately. International Trading, International Wholesaling and International Banking are all inextricably related one to another. If these committees do notling more than study the ground, gather statisties, and bring the various movements into closer contact with one another during the next few years, they will have rendered a wonderful service to the Co-operative Movement evcrywhere. 
THE CONFLICT BETWEEN CO-OPERATIVE SOCIETIES A N D T R A D R

It is obvious that the aim of co-operative consumers' societies gradually to absorb all branches of trade is not at all satisfactory to traders, particularly those who are menaced more directly thereby, i. e., the retail dealers.* In large towns, such as Leeds, Breslau, Bâle, and in many other smaller towns, this evolution is well-nigh accomplished; that is to say almost the entire population makes its purchases at the co-operative store. Thus, in every country the conflict is keen, more so in France than elsewhere, because France is, perhaps, the country in which small trading is the most developed, as are also small industries and small holdings.

* Author's Note. Here is an amusing instance of the way in which traders write the history of co-operation, taken from the Commerical Journal of Amiens, Junc 1st, 1897.

"The idea of co-operation had its birth under the cloudy skies of aristocratic England.

"About sixty years ago a group of workmen founded the first cooperative society under the direction of several clergymen.

"The powerful British industrialists saw in it a very practical means of keeping the workmen under their thumbs, and they subscribed largely to these growing societies. The idea very quickly penetrated to the continent and imperial France opened wide its doors to it. At the present time, co-operative societies spring into existence so rapidly that they are a source of anxiety to all lovers of liberty and social well-being.

"And, what will ensue if this goes on? It is easy to foretell. It will mean the advent of a régime similar to that under which our neighbours across the Channel live, where we can see every day workmen bowed with years and infirmity holding out supplicating hands to the rich industrialists, who throw them coppers from their gilded coaches." 
This question has often served as a platform in electioneering contests, particularly in municipal elections. In Paris, at the time of the municipal elections of 1910, the socialists suffered a relative defeat, which they attributed -not, perhaps, without reason-to the irritation of the traders against co-operative stores. M. Jaurés wrote as follows in "L'Humanité," after the elections: "The small trader has always regarded the custom of workmen as his special prerogative. In his opinion, the workmen commit almost a theft when they think of giving this custom over to their co-operative societies; therefore, he wished to punish them by letting them know the bitterness of defeat." 1

\section{(1) Methods of Conflict}

The methods which traders employ against co-operative socicties are not of the most honourable kind. There is the system of sale on credit, particularly for the working class. There is either a system of a "handover" to the middleclass cooks, sometimes even to the housekecpers themselves, of the "sou par franc" (a halfpenny in the shilling), or that which has become a recognized institution in some countries, particularly in Switzerland, the system of "primes" (premiums) and "timbre-rabais" (discount stamps), which aims at outrivalling the dividend of the co-operative shops. This system consists of giving each customer who pays ready money a token, worth ten per cent. of the value of goods purchased, which may be tendered in payment for other goods. This is, after all, only a caricature of the Rochdale system. This method of advertisement and warfare against

1 Some of the cities in the United States are peculiarly aftlicted with the number of small tradesmen who belong to the Socialist Party and who demand the support of the organized workers on this score. Thousands of such petty merchants belong as well to co-operative societies and all too often serve on the Boards of Direetors. The Cooperative Credit Unions have been used frequently by grasping workers who avail themselves of such credit in order to set themselves up in business for private profit! 
the co-operative societies was very common for some time, but it began to lose ground when it became clear that it of necessity meant either the exploitation of customers or the ruin of the shopkeepers. In Switzerland, there are what almost amounts to co-operative associations of traders, who have united for the distribution of these "discount stamps," each member undertaking to receive them. It goes without saying that they arrange among themselves to raise the prices in proportion to the value of the discounts. However, the traders find in this system a means of fighting against the abuse of the credit system. ${ }^{2}$

But they do not stop here, often they have recourse to more open methods of warfare.

The shopkeepers organize a boycott of the societies, that is, they undertake among themselves: (1) To break off relations with manufacturers or wholesalers who sell to the co-operative societies, (2) to dismiss any of their employés who belong to a co-operative society.

In 1909 , the Lausanne bakers forbade the millers to sell to the co-operative societies, under penalty of exclusion from the markets. The same thing occurred in Sweden with the manufacturers of margarine. In Scotland, in 1897, there was a great fight between the butchers and the Scottish Cooperative Wholesale Society. The butchers boycotted all the merchants and stock-raisers who supplied the co-opcrative societies with meat, and extended their boycott to the United States, and to the ships which carried meat. They even succeeded, with the assistance of the Glasgow Municipal Council, in shutting the public abattoirs against the Wholesale, in order to prevent it from carrying on slaughtering on its own account. However, the farmers were dis-

2 The "trading stamp" was once very popular among merchants in this country, but when the practice developed to such an extent that dozens of companies were manufacturing them and all stores carried them, their value disappeared, and we now see them only rarely. 
pleased at the boycott, and the only result of this campaign was to attract a large number of new adherents to the Wholesale Society, and to cause the raising of a Co-operative Defence Fund, which immediately received $£ 16,000$ from the British societies.

More often the shopkeepers appeal to the Government and demand protection against the co-operative societies. This is achieved by some of the following methods, which are more or less identical in every country:-

(1) They demand in the first place that co-operative distributive socicties should be subject to all trade obligations, and should be liable to taxation from which they have been exempted hitherto, as not being formed of professional traders, as, for instance, the dealers' licence, commercial jurisdiction, bankruptcy proceedings, surveillance from the health authorities, examination of weights and measures, \&c. What annoys the traders most in these exemptions is not so much the inequality of the money charges as the halo of philanthropy and disinterestedness with which these exemptions surround the co-operative societies, and which, in their opinion, forms a very valuable advertisement.

They have obtained satisfaction, however, on all these points. According to French law all co-operative societies formed by shares are subject to all the laws and customs of ordinary trade (Art. 68 of the law of 1867, and confirmed by the law of 1893). And, as regards trade licences, equality of the co-operative societies with the traders was assured by the law of 1905 (sce later). Although this law might in justice be criticized, we have always held that co-operative societies would be wise to accept their trade licence with a good grace, not only that they may have freedom of action, but also because the public would always look upon this exemption as a privilege, and every privilege in a country as jealous for equality as ours is a cause of unpopularity and 
consequent weakness. It is better that co-operative societies should fight the traders on equal terms. ${ }^{3}$

(2) In some countries they demand that co-operative societies, even those which are subject to the same rules and taxes as the traders, should be prohibited from selling to the public. This means that when it is a question of paying the societies would be on an equality with the traders, but when it concerns selling they would be outside the pale of the common law! And this claim, obviously so very inequitable, has been recognized by German law, as we have said before. In Hungary, traders have demanded not only that co-operative stores may not sell to the public, but also that they may not have shop windows in the street, so as to deprive them of this method of advertisement. They want co-operative shops to be hidden away! In Hungary, too, they demanded that co-operative stores should only be formed with the common and unlimited liability of all the members. Of course this clause, in general use among credit societies, would not have the effect of rendering the consumers' societies weaker -quite the contrary! But the traders hoped thereby to frighten and turn away would-be members. At any rate, this clause would be absurd, because consumers' societies, unlike credit societies, are scarcely ever insolvent.

(3) In every country they wish to prohibit all State officials and municipal employés from belonging to co-operative societies, or at least from being members of their executive committees. The argument which they put forward is curious, namely, that Government employés, being paid by the taxpayers' money (and consequently in part by traders'

3 The federal laws in the United States exempt from taxation the surplus-savings of a society if such savings are rebated to the members in proportion to their purchases. Such "profits" as a society makes on sales to non-members however, or such surplus as is not rebated to members, - these are subject to the same taxation as the profits of private corporations. The taxation laws of the various states do not, to our best knowledge, provide any exemption for cooperative societies. 
money), have no right to bring this money to the shops of those who wish to do away with traders! So the feudal obligation of serfs to bring their corn to the mill or to the oven of their lord has been revived in favour of the traders.

This reasoning, however, has not up to the present convinced the Governments, which in France and Switzerland,* and even in Germany, have on several occasions formally recognized the right of their functionaries (military, police, customs, post office, education, \&c.) to join any distributive society, and even to take part in its administrative councils.

However, in various countries-Germany, Switzerland, France-public offices have lent a complacent ear to these claims, and have prohibited officials, if not from joining a co-operative society, at least from belonging to the executive committee, giving as a reason that the exercise of a trade is not compatible with a public office, and that it might even prove for certain classes of employés (such as customs, excise, \&c.) a temptation to misuse their functions in favour of their co-operative societies.

Meantime, the co-operative stores in every country have protested vehemently, and by addressing their complaints to high authorities, have generally won their case. If it is indeed a regulation that an official may not indulge in commerce, it is because his time belongs to the State; but he is not forbidden to be a shareholder, or even a director of a railway, or of a mining company, or of a credit bank. Then why should he not also be a member of simple co-operative societies, even though they sell to the public?

Undoubtedly the late war will have the effect of definitely

* Author's Note. This was by an order of the Federal Council of the 12th February, 1901. In Switzerland, the Federal Government, under the influenee of the traders, forbade employes of the Post Office or the Customs to take office on the executive committees of co-operative societies for fear they might be suspected of certilin abuses of confidence in the exercise of their duties. But under pressure of public opinion this measure was not kept in force. 
putting an end to this campaign, because in the belligerent countries, and even in Germany, the Government is only anxious to take away all restrictions in the matter of officials joining co-operative societies.

(4) Sometimes traders have pushed their extravagance ass far as to demand that every one, except workmen, should be prohibited from joining a co-operative society, or at least that the power of purchasing should be limited to the modest sum of $£ 32 *$ for each member. Others demand that the formation of federations for purchase should not be permitted to co-operative societies. But the Chamber of Arts and Crafts of Hanover took the palm in the way of demands when in 1912 it requested that the creation of any co-operative society "should be made dependent upon proof of the necessity for its existence." 4

\section{(2) Result of the Conflict}

It is a remarkable fact that during this conflict public opinion is generally in favour of the traders, or at least of the petty traders, who are more directly affected by the competition of co-operative stores. People say: "What will become of them when co-operation, by its development, will have superseded them? Are the advantages to be gained

* Author's Note. In a memorandum presented to the Senate by the "Syndicat de l'Alimentation parisienne" during the debate on the law concerning co-operative societies.

In Germany the Union of Discounting Societies demanded that cooperative societies should be forbidden "to pursue any objects of public utility."

4 Some other methods used by the private merchants in their warfare on the co-operatives are:- display of enticing "special bargains," several merchants sometimes uniting in such a campaign so as the better to cut prices on a large number of commodities; bribery of salesmen to induce them to sell to the co-operatives at a higher price or to give a poorer quality of goods; the spreading of malicious rumours throughout the community so as to create distrust of the manager of the co-operative store; in some cases actual bribery of the manager himself, when this man is not a co-operator at heart, inducing him to ruin the business by one form or another of sabotage. 
by consumers such as make it worth while ruining millions of people who form the bulk of the middle classes?" Recently in the Town Council of Manchester-the city par excellence of free trade-during a debate on the taxation of cooperative societies, one of the councillors declared that the development of co-operation "would be the ruin of the city," and another said that co-operation was "preparing to practise a most crushing tyranny." These questions can be answered as follows:-

(1) That the same complaint has been hurled in all times against all forms of cconomic progress-against railways, against machinery, against large banks, against trusts, and above all against large shops. But it ought to be understood that all economic progress aims at doing away with a certain amount of superfluous labour, and at the same time rendering useless those who performed this labour. There are in France two millions of traders, as against 16 millions of producers, agricultural and industrial (workmen or masters): this means that the service of distribution of goods actually finds employment for one man in nine. It is clear that if a system can be found which will do the same service with one man in a hundred it will be progress worthy of congratulation. Those who are freed are thus enabled to undertake occupations more productive than the breaking-up of sugar, for example.

(2) That shopkecpers are only servants of the public. At the same time, the luxury of keeping a large number of servants is a very expensive one, and one which is becoming more and more discredited; it is therefore clear that the number of paid intermediaries should be reduced, especially by the middle-classes. An Englishman, John Watts, said, "It is a strange thing that the poor have the largest number of servants, and must pay for them! If the people wish to become rich, the first thing is to get rid of these." We shall see (Chapter XVI) that co-operative societies only 
require one employé for about forty members; this shows, therefore, some degree of progress. Co-operative association is the only means whereby the consumer can realize this economy, by doing away with this ruinous domestic expenditure. Of course, those who are thus condemned are to be pitied, and perhaps more particularly in this matter because shopkeepers, in spite of the abuses to which they have been forced-less perhaps by the desire for gain than by the pressure of competition-constitute an interesting class of society. They stand for some excellent middle-class virtues -independence, self-help, and thrift. They are the offspring, though in reduced circumstances, of the big merchants who have been one of the factors of modern civilization. From the political and social point of view they stand midway between the conservatism of the farmers and the revolutionary temperament of industrial populations. ${ }^{5}$

But we should investigate and observe whether the traders (independent shopkeepers and individual commercial enterprises) could have held on, even had the co-operative movement never existed. There is every reason to believe that they would have been eliminated all the same, only that their disappearance would have been to the profit of the larger shops and establishments with district branches. This state of things would be even worse for those who interest themselves in the welfare of the middle classes because co-operative societies on the whole support the middle classes rather than exploit them, as it is from them we get the numerous small shareholders, those who are too small to become persons of independent means, but not too small to have an interest in property.

5 It is a significant fact that one can go before any kind of a liberal or radical audience and berate capitalism or condemn the system of business for private profit so long as one deals abstractly with those subjects; but few speakers can get away so easily before our liberals (or even before many of our "radicals" for that matter) if he dare question the ethics of the small business man, the retailer in his little shop. 
And if it were a collectivist régime which was driving him out the death of the petty trader would be more certain still!

For the rest, it does not appear that the trade of the cooperative societies constitutes an imminent peril to the shopkeepers as yet, as statistics do not show a decrease in their numbers, even in the countries and towns where the co-operative movement is most developed.* But what about the future?

If the struggle were only between co-operative societies and petty traders, its issue would be certain, as the latter seem to be utterly condemned by economic evolution as an expensive mechanism, as a wastage of time and exploitation of the consumer. This condemnation, however, should not be pronounced, at least not so absolutely, on small workshops and small holdings.

Perhaps, too, the small shopkeepers would be able to defend themselves better if, instead of decrying co-operative association, they had the sense to utilize it, by combining for wholesale purchase, or even for manufacture, and by allowing their customers to benefit by the economies they were thus able to effect. As a matter of fact, they have tried to do this. In various towns in Germany they have formed purchasing establishments, gigantic warehouses, from which to retail their goods collectively. And in Paris itself, in the interests of the grocery trade they have instituted a purchasing agency in common and have built an enormous wholesale warehouse. But this latter enterprise failed, nor have the others succeeded any better. It seems that there is a

* Author's Note. The number of licensed dealers of Class C. (which - orresponds very nearly to small trading) increased from $1,176,140$, in 1852 , to $1,477,851$ in 1899 , which represents a growth of more than a quarter in less than half a century. But the increase is much more striking if we consider the large towns, and it is the same abroad. In Bale there was in 1877 one grocery shop per 522 inhabitants; in 1900 there was one per 413 inhabitants-and this in spite of the existence in Bale of the most powerful consumers' society in Switzcrland? 


\section{CONSUMERS' CO-OPERATIVE SOCIETIES}

natural incompatibility between the co-operative and the individualist systems.

But the large retail establishments constitute the most formidable adversary of the co-operative stores, especially since they do not limit themselves to trade in "novelties," but are now taking up the grocery and victualling lines. However, co-operative stores are not without certain very real advantages over the large shops, which might ensure their success, because, while offering their members equal advantages (cheapness, cash sales at fixed prices, economy in time for the purchaser by the grouping together of specialties) they are free from the grave handicaps of the large shops, such as unnecessary expenses for publicity, for advertisements, catalogues, shop windows, exhibitions, sales, sales on approbation and other inducements to expenditure, which have actually created a particular form of criminal pathology among lady customers, which is called "kleptomania," the mania for theft. Perhaps there is an element of pride in this austerity of the co-operative shops, and in their contempt for all advertisement, and for everything which might attract the public. It is quite obvious that the appearance of the streets in our larger towns woud suffer badly were their brilliant shop-fronts to be replaced by the sombre windows of the co-operative stores. In this matter a reaction has begun in England, and the co-operative stores are beginning to decorate their windows. If the co-operative store wishes to become the shop of the people it must learn to make itself attractive. The question of publicity and advertising is at present being aired in the English co-operative press. There is reason also for the hope, in the matter of relations, not with the public, but with their employés and workers, that co-operative socicties will not sacrifice the interests of these latter to mere cheapness, as the large warehouses are often tempted to do, and that they will refuse to offer for sale articles of underclothing which may mean a good bar- 
gain for the purchaser, but a wage of $1 \mathrm{~d}$. an hour for the workwoman who has stitched them. Let us add that it is better to see the co-operative shops helping and easing the strain of life for a large number of small shareholders of $\mathfrak{£ 1}$ than to sce enormous establishments whose function is to create a few multi-millionaires.

We are justified then in believing that consumers' cooperation would enable us to escape from the alternative to which the consumer is otherwise exposed-either to continue to support the expenses of the out-of-date mechanism of small trading, or to submit to the bondage of commercial feudalism.

But the new methods of commerce are somewhat disquieting for the future of co-operative societies, as much in the food as in the "novelty" line-we incan the establishment with branches, which might be called the "tentacular" shop, as Verhacen has said of certain towns. In France there are 20,000 branch establishments, belonging to 150 firms only, which are doing a trade of $£ 48,000,000$. Instead of concentration, the new form is extension; instead of waiting for the customer to come, they go out to find him in his small town, in his district, in his village, or in his isolated farm, by employing perhaps the permanent shop, perhaps the caravan, or perhaps by correspondence. For instance, in France, the case of the grocery shop called The Planters of Caiffa, which had thousands of tricycle carts going through the country.

Under this new system some of the advantages of concentration must undoubtedly be sacrificed; for example, the expense of rent is greatly increased. But, on the other hand, there is a saving, first of all on wages and salaries (the employés being replaced by responsible managers, who, instead of being an expense, bring in more money to the enterprise); also on leakage and waste, for both of which these managers are responsible; and lastly, on the expenses of advertising, of 
catalogues, \&c. The manager of each branch must deposit security, which is utilized in the funds of the establishment and is often retained permanently if the manager does bad business and is obliged to quit, in which case he is replaced by a new manager who furnishes a new security.

In order to cope more effectively with these formidable difficulties, co-operative stores have had to use the same weapons, that is, to multiply their branches, with managers responsible for each (as we shall see later, Chapter XVI), but not, however, without doing some harm to the co-operative principle.

But must the struggle end in the extermination of one or other of the two adversaries? Is it not possible to effect a reconciliation between them?

Various pacifists have suggested solutions to this end. One method which has been proposed, and even tried, consists in doing away with the co-operative shop and of delegating to the merchants the duty of supplying the associations of consumers. The function of the latter is to contract with the shopkeepers in the name of the members of the society and to obtain from them a discount as advantageous as the society itself could give, offering the traders as a guarantee the loyalty of the members. Where it concerns consumers who look only for economies it would seem that by this method they could obtain reductions not much inferior to those they might realize by becoming traders themselves and this, moreover, without any managerial worries or risk of exploitation, and without having either to open a shop or collect capital. In short, they need not organize themselves into a "co-operative society" in the legal sense of the word, but merely into a "consumers' league."

This system has been tried, notably in 1901, in the "Coopération des Familles." But it is rather military clubs and students' associations (which have nothing in common with co-operation) which put it into practice, such as the 
Touring Club with its 100,000 members. The Civil Service Employees of the Seine, some of the employes of the P.-L.-M. Company, that of Geneva, \&c., also do trade with shopkeepers for certain classes of goods which, for some reason or other, they do not wish to stock in their own stores, i.e., meat or milk, ready-made garments, or medicines. Under these limited conditions this system might be useful, but it could not become general without definitely ruining co-operation. ${ }^{6}$ 'The great socialist leader Jaurés suggested another method of compromise in an article in L'Humanité. It was that the workmen's trade unions should make an arrangement with the trader, whereby they guarantee the payment of a minimum sum for purchases, for their members. Thus, the traders, having an assured sale, and not having to run the risk of insolvency, would be able to lower their prices and to sell on credit. But to make this ingenious system workable it would first of all be necessary that the trade unions should show better pecuniary guarantees than they do at present. On the other hand, what traders would be chosen as suppliers and invested thus with a sort of monopoly?

In fact, co-operation will never defeat the traders until it is able to do without them.

One other solution (which we only mention here as a çuriosity, and because it is utterly opposed to the preceding one) is that suggested in Camille Sabatier's book on Morcellisme. This is the buying up of the private shops by co-

- At present there is in the United States among ex-service men an organization through which these men can buy at many of the large stores in all the larger cities and receive substantial discounts. The Y. M. C. A. has, in years past, procured the same benefits for its members. Other large organizations have followed this plan.

For 25 or 30 years there has been a Consumers' League in the United States, and for many years its chief concern was that of "white-listing" the best shops or putting its own label on the best goods. These activities have now been abandoned years since and the League concerns itself primarily with legislative welfare work. 


\section{CONSUMERS' CO-OPERATIVE SOCIETIES}

operative societies. But what resources would they have for such a gigantic operation? They could do so by setting aside three-quarters of their profits for this purpose. And to help them the State would allow them a subsidy which (suggests the author), would be at least onc-third of the profits, until the deed of purchase were concluded. Consumers' co-operative societics would then be recognized as useful public establishments, and be subject to State control, which would have the effect of greatly increasing their prestige, and their credit. It is hardly necessary to remark that if this purchase could be effected as easily as the author thinks, it is not at all likely that merchants would consent to lend themselves to it, nor that they would allow themselves to be persuaded that it would be better to sell out at once, as in any case they would be dispossessed, perhaps without any indemnity. Sabatier tells us that he submitted his scheme to a small referendum of grocers in Toulouse, where he lives, and the majority pronounced in its favour. Without contesting this fact we may conclude that the grocers whom he consulted were either doing very poor business, or else that they were amiable philosophers.

Morcover, even admitting that they were willing or constrained, the annual sum available for the purchase would be so ridiculously small-at least in France-that we can hardly estimate the number of centuries necessary for the complete realization of this dispossession. Also, we must consider that from the time the members of co-operative societies found themselves deprived of their full dividends it is probable that they would desert the society and thus it would not be commerce, but co-operation, which would find itself suppressed.

In conclusion, any system of agreement between these two methods of enterprise, which by their very nature are antagonistic, appears to us merely chimerical. But what is very possible, and even probable, is that little by little a 
CO-OPERATIVE SOCIETIES AND TRADERS 189 division of labour will be effected between the two; the trader undertaking the function of satisfying the requirements of an individual, temporary, and fanciful character-things which come under the designation of "la mode"-and the co-operative stores devoting themselves to the supplying of requirements which are of a general, homogeneous, and permanent nature. 
CAUSES OF SUCCESS OR FAILURE OF C O N S U ER S'SO CIETIES

Of all the chapters in this book this should be the most important. Unfortunately, in order to get to the root of the matter the elaboration of a complete psychology of cooperation would be necessary, and this would be a task far beyond the aim of this little volume, and for which, moreover, sufficient information is lacking. Frequently we see certain co-operative societies developing in a marvellous manner, and other dragging along lamentably and failing, without any reasonable explanation.

In France, this mortality is particularly striking. Statistics of consumers' societies published annually by the Board of Labour give the number of societies which have disappeared. For a period of ten years (1904-1914) the number rises to 802 , or 80 per year, which, in a total of 2,500 societies (average of their number between 1904 and 1914) would represent a mortality of 32 per 1,000, being about double the rate of normal mortality in the population. But the official number of moribund societies is very much less than the real figure, which should be almost doubled, showing a rate of mortality of 60 per 1,000, that is, an average existence of from 16 to 17 years. According to the Departmental Reports, the number of births of societies in this period would be 1,457 , and that of deaths 802 . But according to these figures the number of increases during this period would only be 655 , whereas in reality there was an increase of 1,326 . Therefore the true figures, both 
for deaths and births, should be about double the official ones. It is, moreover, easy to understand that many societies are completely unknown. ${ }^{1}$

\section{(1) Administration}

Whenever a society fails, there is always one explanation ready; it is the fault of the management! This is not the only explanation-there are so many; but it is true that this complaint is only too often well founded, and this is but natural. In the first place, as might be forescen, there is the incompetence of administrators who are ill-suited to and not fitted for business, who know nothing of the art of buying at the right time, the right place, \&c., nor the method of fixing the cost price and the retail price, nor the examination and control of the goods, nor book-kecping. Of course, they employ a paid manager to look after all these matters; but it is not easy to find a trustworthy employé, particularly in the early stages of the working of a society, because the capable men prefer to stay on in secure and well-established houses where they have more chances of advancement and larger salaries. It is generally only such men as are not wanted by the ordinary trade who offer themselves to the co-operative societies, so that, as M. Cernesson aptly observes, managers for co-operative stores are recruited in the wrong way, except, of course, in cases where societies find a man with combined business instincts and disinterested philanthropy-but the species is rare. The Revue des Deux Mondes, of October 15th, 1908, contains an article by Cernesson on "Co-operative Consumers' Societies," in which will be found a picturesque description of the co-operative shops

1 There are no figurcs available for the United States which show us the mortality rate among co-operatives. The rate is high here, but probably no higher than it was in most European countries before the movement was well established and national unions and wholesales were set up to support the infant societies until they could stand alone (if they chose). 


\section{CONSUMERS' CO-OPERATIVE SOCIETIES}

in the region of Paris, in which these faults of management are clearly set forth. And, even admitting that the society finds a capable or passable manager, there is always the fear that his work will be hindered by the meddling surveillance of the committee members, who, actuated probably by the worthy motive of taking their duties seriously, interfere in and out of season, often with disastrous consequences. If, as happily occurs sometimes, the efficiency of the manager is clearly shown by his capability, his experience, his services to the society, there is always the danger that sooner or later an opposition party to him will arise which will watch all his actions unfavourably, denounce his despotism, and finally get him dismissed. We have ourselves known the case of the manager of a society who had worked for twenty-five years with extraordinary success, resulting in enormous dividends, having to resign on account of calumnious insinuations which no one believed, but which, nevertheless, gave a sufficient pretext for putting an end to a reign which was deemed to be too long, so as to make room for some person eager to replace him-for there are such, even in co-operative societies! ${ }^{2}$

John Stuart Mill wrote: "The ideal of democracy is that the people shall be masters, but employ servants more capable than themselves." This is precisely the ideal of a cooperative consumers' society; but, unfortunately, it is not easy to realize. We are thrown, as it were, between the two rocks of Scylla and Charybdis. On the one hand, it is desirable and even indispensable that every person in the association, administrators as well as ordinary members, should take an active part in the life of the society, even if the latter only do so by objecting when they are not satisfied, and by being present at meetings; it is essential that they should

2 This often happens in American societies, too, but, on the whole, our movement is younger and the pioneer spirit is still active nearly everywhere. More of our failures are due to poor management, ignorance on the part of the directors, or lack of educational work among the members. 
feel that the socicty belongs to them. And on the other hand, they should not shackle the management by undue interference. It ought to be possible to reconcile these contradictory elements by establishing a well regulated division of labour, a separation of control and execution, various members undertaking these functions in rotation; but even thus a great deal of tact and goodwill is necessary to make everything work smoothly (see Chapter xvi, The Employés and Workmen in Co-operative Societies).

The very constitution of a co-operative society as created by law and the nature of things (i. e., a society of shares) is bound to make good management difficult. These difficulties already exist in large capitalist companies, obviously inferior to individual enterprise from the point of view of initiative and control, but they become much more serious in a cooperative society. In capitalist companies the executive committee is, as a matter of fact, omnipotent, if it were only because it often owns the large majority of the shares. They only have one annual general meeting, the shareholders do not attend in any numbers-indeed, in some companies only the large shareholders are admitted-they very seldom speak, and when they do they get little or no satisfaction from the chairman.

Co-operative societies, on the contrary, are genuine miniature parliamentary republics, in which there are nearly always two parties, the one in power, and the opposition; and, naturally, the latter tries to upset the former, or at least to prove it in the wrong. At every general meeting -and there are at least two a year-there are numerous and vehement accusations, particularly if, for some reason, the profits have decreased. We do not mean to assert by this that there is great enthusiasm among the members about attending the meetings-there are societies with 20,000 members, of whom only some 300 or 400 come to the general meetings-but it is precisely the turbulent ones who are 


\section{CONSUMERS' CO-OPERATIVE SOCIETIES}

most assiduous. And it is all the more difficult to maintain order in discussion because the chairman of the meeting is almost always ignorant of the administration of the society, being elected by the most energetic canvassers of some name or other. Thus it happens that very delicate questions, and even a complete policy which has been slowly and carefully built up by degrees, may be left to the mercy of an absolutely blind vote.* 3

* Author's Note. "Complaints increase, questions and challenges of various kinds are interchanged. ... There comes a time when, tired, worn out, the mass of the people is incapable of doing any business, no matter how important it may be, perhaps the revision of rules, loans, or the building of some property. Dinner hour is passed, the housekeepers have gone away, and cries of protestations arise, both jocular and vehement. Dinner!... And, like an irresistible waterspout, deaf to the entreaties of the authorities, this mass surges outside, heedless of the demoralization it leaves behind amongst the levelheaded co-operators and the personnel embittered by humiliations suffered." (Cernesson; article cited above.)

According to Cernesson, in the article quoted, in the Parisian Workmen's Co-operative Societies, "No one can be a candidate (for the executive council) if he has not made an official declaration of candidature-an ingenious method of eliminating modest ones.... On his name being called, each one must rise, mount the platform, and himself expound his qualifications as administrator. ... It is easy to conceive that under such conditions the influx of serious-minded candidates will not be great-and in fact, there are often empty places which have to be filled by drawing lots. In the society la Prolétarienne, at Montmartre, drawing lots by a wheel of fortune is practised regularly according to the rules for the choosing of a certain number of the executive."

3 In the United States we see this kind of thing far oftener within the labor union than in the co-operative society. Such factional differences develop much more easily in the organization which has fewer actual accomplishments to engage it and is therefore compelled to live too much for the sake of future hopes or mere perfection of the organization machinery. We have seen many of these bitter internal schisms in labor unions or in political organizations, and they seem to be particularly virulent among the peoples who are of Latin origin.

Unfortunately there has been, since the advent of Communism in the United States and the resulting cleavage in the ranks of the Socialists, a conspicuous exception to the general rule mentioned. The Finnish societies have been seriously split on this political rock in the majority of the communities where they are organized co-operatively, and the co-operatives have suffered accordingly. 


\section{(2) Orcrlapping}

We have already remarked, apropos of international statistics of co-operation, that herein lies one of the most unfortunate characteristics of French co-operation-the number of societies is everywhere larger than formerly; but it is obvious that when we see in one town (sometimes a very small one) half-a-dozen, indeed up to twenty co-operative stores, it is a sign of weakness and not of strength to the movement. This overlapping has the very natural result that all the societies are eager to secure new members, thereby reviving all the evils inherent in competition, which co-operation by its very title is seeking to abolish. It is inevitable that societies should aim at attracting new members, whether by swelling the dividends or by lowering prices-two inverse tendencies, equally undesirable; add to these the increase of general expenses, whether it be due to the multiplicity of premises rented and of employes whose time is wasted in looking after rare customers, or whether it is by the delivery of goods to customers' houses.

In this respect, we often see three or four vans in the same town overlapping each other in delivering goods to the various members, where one cart would be all sufficient. Thus, the general expenses, according to Cernesson, amount to 13 per cent. on the sales in Parisian societies, while they do not exceed 8 per cent. in English ones. Add also to this that it is already a difficult enough task to find in the same locality enough capable men to form an efficient executive committee, and it is then highly improbable that good working committees could be found for so many overlapping societies. The 3,200 consumers' societies in France require a personnel of from 30,000 to 40,000 administrators. Where are these to be found?

This state of things arises principally from the French 
character, which loves division, and it obtains not only in the small co-operative world, as it is the same in friendly societics and in all French associations. But in the co-operative movement this characteristic is accentuated:-

(a) By the tendency to form professional co-operative societies. Thus we see in many towns a co-operative store for railway employés next door to the ordinary one; we may even see (if the town is large enough to have two large railway companies), one store for the employés of the P.-L.-M. and another for those of the Midi. Sometimes to be merely professional is not sufficient for co-operative societies - they must sub-divide into special departments. So we see at Avignon two or three co-operative societies for the P.-L.-M., including one for the traction department and another for the trade staff.

(b) By the introduction of politics, religion or socialism into the societies. This has occasioned severe censure on us from other countries, such as that recently pronounced by Mr. McInnes, a member of the Central Committee of the International Co-operative Alliance: "France is the only country which does not show the wished-for progress; but any one who is familiar with the co-operative movement in this country will know how very greatly it is split up by politics and religion." Where a society openly sets up the red flag, the inevitable result is that those who do not approve of this will start another society. In the large towns in Belgium there are often two distinct societies, the socialist and the Catholic, sometimes even a third, the Liberal. In the large industrial French towns in the department of Nord, "red" and "yellow" stores are to be seen facing each other with alternating power. But we shall leave this important question of the introduction of politics into the co-operative movement to another chapter.

(c) By the specialization of societies-some limiting thcir 
activities to baking, others to the sale of groceries, and others to the sale of wines, \&c. In this way there would lave to be as many shops as specialties.

As a reaction against this tendency the societies in any one town should be induced to unite as the English ones do, which explains the phenomenon already alluded to on page 56, namely, that the number of societies is diminishing, while that of the members is rising steadily.

In Germany, it is by this system of amalgamating the existing societies in the same town that they have been able to create the colossal societies, of which we have spoken elsewhere. They are only at the beginning of this method in France, and are meeting with active resistance from societies, which the smaller they are persist so much the more in maintaining their independence, perhaps from some feeling of pride. Each society has, of course, its own little history and, after all, it is pleasant to be among one's own friends.

For the rest, it would be very imprudent, where this amalgamation has taken place, to proceed by closing all shops which have amalgamated, with the sole object of reducing general expenses and of concentrating all departments into one large bazaar; the remedy might be worse than the disease.* The building of this great edifice would either absorb all the society's capital, or necessitate a loan. On the other hand, many members, finding the central shop too far away from them, might leave the society. The society should not be out of reach of the members. What is required is one management but with branches in all dis-

* Author's Note. It is a generally admitted law that the percentage of general expenses varies in an inverse ratio to the turnover, and this is verified in practice, but only to a certain degres of expansion. Beyond this point the law is reversed, and this is why there is generally a limit to the growth of any economic enterprise, which should not be exceeded. 


\section{CONSUMERS' CO-OPERATIVE SOCIETIES}

tricts where there is an adequate nucleus of members. The large Parisian society has 330 branches, and that of Bâle more than 100.

But the danger of centralization is not all, there is also the danger of concentration of administration. The large societies obviously require administrative capacity proportionate to their importance, and also much more attention from those who undertake such work. They also offer more temptations to dishonesty and more difficulties in the matter of control; the members often do not know each other.

For these various reasons it is possible that complete amalgamation should be deferred, and that it might be wiser to be content with abolishing competition by effecting an understanding among the societies-a cartel-each one undertaking to limit itself on some pre-arranged system, to establish the same rate of dividend and to do all purchasing in common. During the war the movement in France towards amalgamation has greatly developed, and so far has given good results. Still we do not think that the advice given in the text is not wanted. The Union $d u$ Coopérateurs in Paris, which is the result of the amalgamation of a dozen societies, has today 184 stores. Now it is attempted to set up co-operative societies that are no longer local but regional, with branches in places where they respond to local needs. The reconstruction of the co-operative organization in the regions of France which were destroyed by the invasion is the special work which will be done by the regional societies.

\section{(3) Character}

The degree of moral character of the members of a co-operative society is certainly one of the most important factors, if not the most important, in the success or failure of the store-(Robert Owen, not without reason, called his system "The New Moral World"). It is important for thi 
members of committee, because morality alone can preserve them for the temptation of demanding or accepting bribes, important for the ordinary members because this moral sense will help them to choose honest administrators, because it saves them from internal disputes and, finally, because it keeps before their eyes the essential duty of a loyal member, which is to purchase at his own store-even if the grocer's shop is more convenient, or offers such and such an article cheaper-and to participate in all the social life of the society.

But, as we have remarked elsewhere (page 85) with regard to these elementary duties of solidarity, the members who scrupulously fulfil them are rare.

We must admit that if the co-operative movement in France is very much behind that of other countries, it is partly because the standard of morality in co-operative societies, even though generally superior to that of ordinary trade, is not yet very high. It is not rarc to hear of socicties which have failed through the shameful practice of "commissions" and of many others which have not succumbed to it but which continue to foster this evil, doing nothing to cure it, even refusing certain remedies such as adhesion to purchasing federations, because this would suppress the evil too drastically. Undoubtedly it is a great danger for workmen who have never had more money than their weekly wage, to have to deal with a business of thousands or millions of francs. Besides, it is an easy and insensible descent from the small innocent present made by the wholesale traders in the shape of a box of oranges for madam, or some bon-bons for the children, to so much per cent. offered, and at times even impudently demanded, on each purchase. These wholesalers and their representatives are very clever in playing the rôle of tempters. And we must remember, too, that commissions are customary in trade, and it is difficult to I. - ivate the line of demarcation between the lawful commission 
which will benefit the society and the unlawful one which is put in the pocket. As an illustration to this chapter we should mention the melancholy history of the society " $l a$ Moissoneuse," founded in 1875, in the faubourg SaintAntoine, Paris, exclusively of workmen, which had 16,000 members, and which succumbed in 1903 owing to the malpractices and the vices of the executive committee. ${ }^{4}$

Consumers' co-operative societies which have in their ranks employés of public services (such as post office and telegraphic officials), professors of colleges or of academics, soldiers, small houscholders-in a word, what we call the middle classes-are generally more free from this evil, because the members know each other better, and because of the habit they have acquired in their profession of keeping accounts and managing money keeps them better on guard against temptation. We do not at all wish to say-far from it - that the workman's morality is naturally inferior to that of the middle classes, because, on the contrary, it is from the latter that workmen have learned the practice of bribes; but we contend that where middle classes and workmen are associated in the same society they feel themselves under observation by each other and strive to behave well for the honour of their class. We cannot help regretting, therefore, from the point of view of successful business working, the exclusion of the non-labour element from the socialist societies. In any case, this is one proof

${ }^{4}$ Such practices are not common to the American societies, although there are too many failures that can be attributed in part to such causes in general. Many of the Societies which have had their origin in a mere desire for money-saving alone have begun their descent toward failure by granting various fees to officers and directors. Commissions to the manager can easily be justified in such a society; and soon there is a scramble under way among the leadcrs, each of whom wants to profit more than the others. It is well that such societies are very short-lived. Some of them have been saved by the more honest and intelligent of the members who succeed in having the old Board of Directors thrown out, a new manager installed, and true co-operative principles put into practice. 
more of the need for co-operative education, as we have already remarked (see page 93 ).

Moreover, when we speak of morality as a factor of success or failure, this word must not only be understood in the narrow sense of honesty. We must understand by it everything which strengthens the feeling of co-operative solidarity, everything which develops zeal in the members of a society to fulfil their duties as such, beginning by loyalty in their daily purchases. Even in English co-operation there is a matter far from gratifying, which is occupying the attention of the leaders of the movement. For thirty years the average of purehases made per member has remained stationary, and this, be it noted, notwithstanding two things which should have raised it considerably, to wit, the rise in wages and the rise in prices. The present state of things is, therefore, a retrogression. ${ }^{5}$

The causes of inferiority which we have just indicated do not apply in the same degree to co-operative societies in every country; the situation in English, German, and Swiss societies appears to be much better. Although the practice of illegal commissions has sometimes been toucled upon in English co-operative papers, although it has often been denounced by traders (who are somewhat open to suspicion as witnesses) we may say that it is very rare, and it is severely repressed both by law and by custom. There is a special law called the "Bribery and Corruption Act," August 4th, 1906, which enacts that any employé who accepts secret commissions can be dismissed without any indemnity, and that the bargain corrupted by any such commission may be rendered null and void.

And here we are led to investigate the general causes

- In the face of the competition offered by the cut-price chain stores and the other stores which give unlimited credit, the co-operative in the U. S. must put its chief reliance in Education, convincing the membership generally that despite all appearances to the contrary, private business cannot do for them what co-opcration can. 
which can be separated from the contingencies which govern particular cases.

\section{(4) Race}

Race, or at least the admixture of factors designated by this somewhat indeterminate word, exercises an undoubted influence on the co-operative movement. As proof of this, we need only compare the Anglo-German countries on the one hand, with the Latin countries on the other, looking back on the table we gave (page 49). It will be seen that while for Great Britain, Holland, Germany, Austria, and the four Scandinavian countries (Finland included), the proportion of co-operators to that of the total population is an average of 131 per 1,000; in France, Belgium, Italy, Spain, and Portugal, it is, on the contrary, only 65 per 1,000 , just half.

But here is a more striking proof, because it deals with the inhabitants of the same country, and thereby many disturbing factors, such as inequalities of civilization, education, wealth, \&c., may be almost eliminated; let us look at Switzerland. In the German cantons the proportion of co-operators in relation to the population is about 7 per 100 ; in the five Latin cantons (four French: Geneva, Vaud, Neuchatel, Fribourg; one Italian: Tessino) it is 3 per 100. In the same way the Flemish provinces in Belgium show a great superiority to the Walloon provinces, though less than in Switzerland. However, co-operation seems to make the most rapid progress in the "Romanic" cantons, so that the proportion is becoming more equal. Thus, in the last edition of this book (1910) we remarked the fact that the cooperative newspaper in the French language had only 17,000 subscribers as against 123,000 for the same in the German language, which meant a proportion of 1 in 7 . Then in 1914 the number of subscribers to the newspaper in the 
French language rose to 59,000, and that to the newspaper in German to 183,000 , which gives the proportion of 1 in 3, that is, more than that of the two languages in Switzerland, which is only 1 in 4 .

It appears obvious from these figures that the AngloGermanic race possesses exactly the virtues-perhaps the faults also-which tend most to the success of co-operation; the love of order, the respect for discipline, the spirit of solidarity, the passion for organization which helps towards the formation and the leading of large bodies of human beings. Trusts and cartels are a manifestation of this same spirit.

The Latin peoples seem to be more endowed than we are with the faculty of association. Italians have shown remarkable aptitude for co-operative association, particularly in certain forms. What, you will say, is France then not Iatin? By language and civilization, yes, undoubtedly, but not by blood. She is of Celtic race, of Gaulish blood, of those Gauls whose unruly clans Vercingetorix himself could not unite into a national federation. The Irish are our nearest relations from the racial point of view. Now, if we compare the development of co-operation in Ireland with that of the United Kingdom we shall be struck by the inferiority-at least as far as concerns the form of co-operation which is the subject of this study-consumers' cooperation. Consumers' co-operation in Ireland only had 17,000 members to $4,500,000$ inhabitants - that is a proportion less than 4 per thousand-while in England they run to $2,550,000$ members in a population of $37,000,000$ of inhabitants, that is 70 per thousand. 'True, Wales, which is of pure Celtic race, and Scotland, which is partly so, have a proportion of co-operators equal to that of England, but they have been anglicized.

Ireland, though poor in consumers' societies, is rich in 
agricultural producers' co-operative societies, but we shall explain later on (page 205) that this form of co-operation implies a very different type of mentality.

\section{(5) Environment}

Environment exercises a very strong influence on cooperation. An industrial district is much more favourable to consumers' co-operation than an agricultural one; it is almost indispensable. It is only necessary to look back on the table already mentioned (page 49) to acknowledge that the development of co-operation in each country is almost in proportion to its industrial development. In Switzerland, the three largest co-operative stores, of from 20,000 to 40,000 members, are in the three industrial centres, Bâle, Zürich, and Geneva. In France, if we draw a line of demarcation from Lyons to Bordeaux we shall see that an immense majority of co-operative consumers' societies are in the northern half, very few being in the southern part. There are, however, large and important towns in the southern division, Toulouse, Montpellier, Nîmes, Marseilles, Toulons, Nice, but the industrial movement there is very weak. The explanation of this is simple. The industrial populations, grouped already by force of circumstances in their common workshops and in the quarters where they live, are ripe for grouping, as in a trades union or in a co-operative society. Moreover, the pressure of the cost of living inclines them towards co-operation. Country folk, on the contrary, have few wants, and those which they have are easily satisfied. To a large extent they are provided for by the produce of the farm itself, and the rest are procured through travelling salesmen. Country folk have either no time to go to a co-operative store or they prefer to do their purchases in the town on fair days. Further, their individualist temperament does not tend to association. True, in France the "syndicats agricoles," and abroad the rural 
banks, have succeeded brilliantly; but this is because these forms of association allow more independence to their members; they secure advantages for them without demanding from them, we may say, any sacrifice. On the other hand, agriculturists have very little sympathy with consumers' eo-operative societies, because they think more of the interests of the producer than those of the consumer. They are protectionists; they want high prices; they supply the middle class and the petty traders. And this is why we see the "syndicats agricoles" in France, while claiming the right to sell to their members all their agricultural requirements, disapproving of those among them who sell goods and merchandise for their members' personal use, thereby becoming consumers' societies; they do not wish to enter into competition with the local traders. $A$ proof that this antagonism is real is that every attempt made during the last thirty years to effect an agreement between the consumers' co-operative societies and the agricultural societies has failed, though it would seem quite natural that the former should obtain from the latter all the food commodities they require.

As industrial districts are more favourable for the development of consumers' co-operation than for agricultural co-operation, it follows that consumers' socicties thrive better in towns than in the country. They are products of urban life.*

However, there is one notable exception to this rule. Consumers' societies are not really successful in very

† Author's Note. It must be admitted, however, that in Denmark consumers' co-operative societies are very numerous in country districts.

"Author's Note. This question arose recently, owing to a judginent of the Court of Appeal, which prohibited the "syndicats agricoles" from sclling goods to their members. This decision caused inuch perturbation in the syndical worid. But the majority of syndicats adopted the distinction which we have indicated, namely, the right of the syndicats to sell all requirements for agricultural production, but not for personal consumption. 


\section{CONSUMERS' CO-OPERATIVE SOCIETIES}

large cities, that is to say, in capital towns. We might assert that up to the present London is a desert as far as co-operation is concerned ${ }^{6}$ and in Paris it is only in the suburbs that co-operative stores are to be found, and many of these are still only badly managed.

As far as country districts are concerned, the explanation is simple; in a sparsely populated neighbourhood the people cannot group themselves round a common shop, every village has its small hucksters, or is satisfied with travelling salesmen. ${ }^{7}$

But as for the capital towns, the explanation is not clear. It may be, inversely, that the most powerful commercial oganizations are found in them; it is very difficult for co-operative stores to fight against the competition of large strongly organized businesses, whether it be for grocery, for fancy goods, or for furniture. It may, perhaps, also be that the inhabitants of a capital city often move from house to house, which renders it difficult to form the nucleus of crystallization which is indispensable to the prosperity of a co-operative society. ${ }^{8}$

${ }^{6}$ But this is no longer the case; in 1922 the three London societies have 300,000 members.

7 The farmers have developed a good consumers movement in the United States and fully hold their own with the workers of the small towns. They are aided, of course, by the absence of much of the chainstore competition which the town worker has to contend with. And again, they have in many states a good buying agency in the farmers' central exchange. But in this country also, the farmers have developed their marketing organizations far beyond their purchasing societies. In the majority of cases the latter spring out of the former as the farmers realize it is just as important to control the spending of their money as it is to get that money in the first place.

8 New York, Chicago, and other large cities suffer from a dearth of co-operative societies. Much of this can be laid to the nature of the life which the city resident leads; the multiplicity of his daily contacts and the superficiality of his interests tear down within him those qualities that go to the making of a good co-operator. $\mathrm{He}$ develops the mental and spiritual life of the gambler. 
THE RELATIONS BET TEEN CO-OPERATIVE S O C I E T I E S A N D TH E S T A T E

[Author's Note.-This chapter, which does not appear under this title in the French text, takes the place of Chapters XIII and XIV in the French edition, which are entitled, "The Legal Aspect of Consumers' Societies" and "Taxation," respectively. These chapters are of little interest to American readers. We have retained those parts which are of general interest, and added a short summary of the new relations which have been established be tween the State and the co-operative societies as a result of the war].

The relations which can be established between co-operative societies and the State are manifold, and, at least as far as concerns France, tend to multiply. They may be grouped under the four following sections:-

(1) Relations with the State in its capacity of legislator: The laws about co-operation can be more or less favourable.

(2) Relations with the State as administrator: The Government can delegate the administration of certain public services to co-operative societies.

(3) Relations with the State as regards taxation: The taxes which apply to co-operative societies can be more or less remitted.

(4) Relations with the State as a lender of capital: The State may advance money to co-operative societies to help in their establishment. 


\section{Legislation}

The legal conditions necessary for the formation and good administration of a consumers' co-operative society are as follows :- 1

1. A minimum of formalities and expenses in constituting the society.

2. A minimum of liability on the part of the members for the engagements entered into by the society. This is the more necessary in that, since the liability would generally fall on workmen, who usually have no property, it would, in fact, be illusory.

3. The division of the capital into very small shares, so that it can be subscribed by workers who have only small savings.

4. The possibility of increasing the capital indefinitely in accordance with the possible extension of the society and the increase in membership.

5. Civil personality allowing the society to act in its own name without having to bring in all its members.

The different forms of contract of association which the law allows consumers' societies are far from satisfying all these desired conditions equally well.

The form usually adopted is a society of shareholders. This offers many advantages:-

(a) The capital is divided into shares which are within the reach of all purses. The value of the share, which for

1 The United States is a federation of states, each having its own laws relative to business privileges and practices. Many of these states have enacted legislation favourable to the formation of co-operative corporations; other have given no attention whatever to co-operation (unless it be to co-operative marketing among the farmers). Where there is no legislation providing for the formation of cooperatives, these must be formed under the business corporation law, and such co-operative features as are desired must be written into the by-laws of the society (provided these do not openly conflict with the laws under which the society is incorporated). A good federal law or uniformity of state laws is much needed. 
CO-OPERATIVE SOCIETIES AND STATE 209 ordinary companies is generally $£ 20$, can be reduced to $\mathrm{fl}$ for co-operative societies. Further, it is not necessary to pay the whole value of the share on subscribing (to "free" the share as it is called): it is enough to pay one-tenth or the very small sum of 2 s.

It would be difficult to devise easier conditions for the formation of capital.

(b) The liability of each member is limited to the amount of shares subscribed for. It is thus reduced to the minimum, though the member is liable for the whole share subscribed for, and not only for the part paid up. In fact, if a socicty failed it would be very difficult to make workmen pay up the unpaid part. This is the reason why every society of this nature in England has to have following its name a word intended to warn the public of the non-liability of members, namely, the word "Limited."

(c) A co-operative society should always kcep its doors open to those who wish to become members or those who wish to leave. To this end it is necessary that the number of its shares (and in consequence the amount of its capital) can increase or diminish at any time. This is essentially different from an ordinary company where the capital and number of shares are fixed by its articles of association, and in consequence no one can become a shareholder until he finds an existing shareholder who consents to sell him his shares. Co-operative societies are known in French legal phraseology as societies "with variable membership and capital." The French word "société" is used both for companies and societies in the English sense of the word.

(d) The society has legal personality, which means that it has an existence in law as distinct from its members. In England this legal personality was at first refused to co-operative societies, and the law allowed the treasurer to steal their cash without leaving them any remedy. The 


\section{CONSUMERS' CO-OPERATIVE SOCIETIES}

Act of 1852, which gave them a legal existence, was an event of capital importance in their development. Its passing was due to the generous campaign of the Christian Socialists, and also of John Stuart Mill (see above, page 36).

An important result of these conditions from the economic and social point of view is that the value of the share can never rise, however prosperous the society may be. (See above, page 101). How ean it rise, since the shares register is always open to whoever may ask for shares? The supply is always equal to the demand. There is besides another reason why the share can never rise in value, whatever profits the society may make, and that is, it carries no profit, but only a fixed interest. This is a characteristic difference from ordinary companies, whose shares, being limited in number, ean rise indefinitely, and may be worth a fortune to the lucky original holders.

A question with which co-operators are concerned is that of the eventual dissolution of the society, and what is to be done with the common funds in such a case. According to Common Law, if the society is in the form of a commercial or civil company the common funds should be divided among the members. This rule is repugnant to ardent cooperators, because they see in such division, and in the enriching of the individual which may come from it, a sort of bankruptcy of the co-operative idea, and they fear, not without reason, that the members, in their eagerness to gain this windfall, would themselves hasten the division by voting for the dissolution of the society. In order to stop such suicide it is often laid down in the rules: (1) That the society shall exist in perpetuity, and that its dissolution can never be declared. (2) That in the case of the extinction or dissolution of the society its assets shall be given over to another co-operative society, to a federation, or even to the commune, that is the local government body. 
As far as the first is concerned the law does not allow the members to prevent their successors from doing what they have done themselves, and if the members in the future are unanimous at any time in deciding on dissolution they will always have the right to dissolve. Further, if a member can discover and apply some reason for dissolution which has been laid down in law dissolution can always be ordered by the courts, any clause to the contrary notwithstanding. French law, in fact, does not allow that any person can bind limself by contract in perpetuity any more than it allows perpetual vows.

As regards the second clause, it is valid in so far as it applics to acquired money and reserve, but it is not valid for capital that has been subscribed by shareholders, which cannot be taken from them.

Those who do not know much of legal matters ask: Why so many difficulties? Why are men not left free to associate as they like and to draw up their rules as seems to them good?

The answer is that this freedom could be a great source of danger for strangers, and for the members themselves; for strangers, because they might become the victims of a society which only offered them an illusory security; for the members, because they might be robbed by an unscrupulous minority of themselves; and finally, it would be enough for companies to take the often untruthful title of "co-operative" to have the right to evade all laws. These dangers are so far from being unreal that in spite of the laws which are found troublesome they are realized in the most scandalous way every day. ${ }^{2}$

2 Because of the great number of promotion schemes which bear the name "co-operative," many states lave begun lately to define the limits within which that word may be used by a corporation. Even these laws however, are for the most part insufficient, and The Cooperative I.eague has now drafted a Model Co-operative Law which is being presented to the various state legislatures. 


\section{CONSUMERS' CO-OPERATIVE SOCIETIES}

But one ean at least improve the existing laws by making them more liberal. The distrust which the French State has always nourished towards all forms of associations still weighs on us.

Up to last June there was no special legislation in France for co-operative societies; they were subject to the same laws as ordinary companies. Only in 1917 was there a special law published, but even this only affected those co-operative societies which wished to benefit by the State subsidy with which we shall deal later. The principal provision of this law of May 13th, 1917, was that only those societies should be recognized as co-operative which distributed their profits to the consumers, and not to the shareholders.

We shall also mention the creation in France, in 1917, during the course of the war, of a High Co-operative Council, which is an official body, inasmuch as its meetings are held at the Ministry of Labour and its object is to prepare and discuss the legislative schemes which are of interest to co-operative societies. This Council is divided into two sections, one for the producers' and the other for consumers' societies. Two-thirds of its members are elected by the societies, and one-third are nominated by the Government.

\section{Public Services}

During the course of the war, for the first time in France, the State delegated to co-operative societies the management of certain public services, that is to say, the societies were to administer them on behalf of the State or municipalities in the interest of every one, and not only of their members. ${ }^{3}$

3 Nothing similar has been done in America. During the war, however, there were many co-operative ventures among the civil servants in Washington and elsewhere. Almost all of these societies failed early; and the stores operated by the Post Office employés in New York City for several years were closed late in 1921 by order of the Government. There seems to be no place for co-operation under the support or protection of the Government in the United States. 
This change of tactics began in 1916, when the Government handed over to the Parisian co-operative societies the sale of frozen meat, the Government having the sole right to import this commodity. In the following year the Government delegated to the societies the sale of various goodsof which the right of importation was reserved to the State -and later they gave them the management and control of numerous co-operative restaurants for the working class (see pages 131,132$).^{4}$

In addition to this, on all the new consulting committees which have been created for the consideration of food supply, the high cost of living, the struggle against alcoholism, \&c., the Government has reserved a certain number of places for co-operative delegates, so that we may claim that the latter now rank among the official institutions of the State.

\section{3 'T'axation}

Until lately the consumer's' societies in France were exempt from the tax known as the "patente" or licence. The Council of State consistently took up the attitude that consumers' co-operative societies did not trade in the strict sense of the word. Co-operators do not buy for re-sale as do traders; they buy to divide among themselves the goods they need for consumption. This is so true that the employés in a co-operative store are generally called "distributors" (répartiteurs) not salesmen (vendeurs).

It is hard to believe what strong passions have been aroused by the question of the licence-on the one hand, by the co-operators who claimed exemption, and, on the other, by their competitors, the traders, who claimed that the law should be applied equally to all. This is the rock on which the project of a regular co-operative law split five or six

4 The Staff of the Co-operative Reference Library, Dublin, is authority for the statement that similar action was taken by the German and Austrian governments. 


\section{CONSUMERS' CO-OPERATIVE SOCIETIES}

times and was at last completely wrecked, as the majority in the Senate were traders, that is to say, in favour of the imposition of the licence.

The question is now solved. The Budget of April 19th, 1905, brought all co-operative societies within the licence law, even those which sold to members only, on the same conditions as ordinary traders. The one exception is societies which have no shops (at least, shops for retail selling, but only depots for depositing their goods), and which confine themselves to bulking the orders of their members. There are hardly any societies in a position to benefit by this exception. This exception was made in favour of agricultural societics. The agricultural socicties are co-operative purchasing societies, but they purchase for production, and not for consumption, and a large number of them are only depots which confine themselves to bulking their members' orders. They thus come under the exemption laid down in law.

Thus have the traders triumphed. But have the co-operative societies suffered much by this law? We do not think so. What they feared most in the application to them of the licence was not the pecuniary charge easily compensated for by the profits realized from sale to the public, liberty for which is implied in the licence, but the moral effect. Co-operators thought, as did their opponents, that the application of the licence would cause the co-operative societies to become like ordinary traders, and so become liable to a number of burdensome legal consequences, such as being subject to the commercial courts, which are composed of traders, that is to say, their opponents. It also involves the civil and even penal responsibility of the officials of the society in case of infringement of the laws against selling adulterated goods. A more serious consequence is the incompatibility of the functions of managing a licensed society with the holding of any public offices, and even 
certain liberal professions, such as that of barrister-at-law, which will have the effect of depriving co-operative societies of the help of many persons who could render the most valuable service.

We, however, were always among that small group who thought these fears ill-grounded, or at least greatly exaggerated, and who held, on the contrary, that co-operative societies would gain by paying the licence fees. They gain freedom of action-which is never bought at too high a price - freedom to sell to the public (though it is not necessary to use this power the greater number of societies have hastened to use it, since, having to pay the cost, they wish also to make the profit); and liberty to use their profits as they wish. It is worthy of notice that, according to the law we have just been writing about, the payment of the licence duty not only confers the right of selling to the public, but also the power of using the profits for other purposes than the repayment of a bonus to the individual members, e. g., propaganda, insurance, \&c.

Fiven though the payment may induce many societies to sell to the public it does not necessarily follow that the co-operative ideal is debased, or that a trading spirit is introduced. The example of the English societies reassures us in this respect. It is well worth remarking that the socialist societies, which have undoubtedly a real feeling of solidarity and fighting fervour, have shown themselves strongly in favour of applying for the licence. We must remember, however, the rule referred to above (page 74), which is that the profits made from sales to the public must never be divided among the members, but must be devoted to some work of general utility.

But now that we have the general tax on revenue, is the old discussion raised by the licence question to be re-opened?

In England, the question of the tax on revenue called the income tax has been a matter of controversy for a long 


\section{CONSUMERS' CO-OPERATIVE SOCIETIES}

time. According to the law, joint stock companies have to pay a tax on their profits (Schedule D), and deduct it from the dividends paid to their shareholders. The traders demand that the co-operative societies should be subject to the same conditions, and recently (June $\%$ th, 1916) the Manchester City Council passed a resolution almost unanimously (except for half-a-dozen councillors, who were also co-operators) calling the attention of the Chancellor of the Exchequer to the injustice suffered by all who pay income tax, owing to the exemption enjoyed by the cooperative societies. The question having become more acute since the war has caused a large increase in the income tax. The co-operative societies, however, on their side, have not ceased to protest against the payment of income tax, and so far the State has taken their view. Their arguments may me stated as follows:-

Co-operative societies cannot be subject to the tax, since they do not make profits. Although the English word "dividend" seems to confuse the issue, the societies do not pay dividends, but, in the more accurate French expression, return the overcharge.* It is the rule in England that the revenue authorities do not demand the tax from the societies with an open share register, which is exactly the case of the consumers' societies. Nevertheless, English co-operative societies have submitted to paying the special tax on war profits. That they consider is a patriotic act on their part, but it may always be brought up against them as a precedent.

But when it is admitted that the society is not subject to a tax on its income, one may ask whether its members, as

* Author's Note. This argument always seems to lose its force as regards societies which sell to the public, as is the case with the majority of English societies. Co-operators maintain it, however, even in this case, on the ground that the profits made by the sale to the public are not distributed among the shareholders. This, however, is open to argument (see above, page 74). 
individuals, should not pay it on their bonuses? 'The answer is again in the negative, for the same reason as the former, namely, that the bonus is not income, but a repayment. Lately there was another reason why the tax should not be imposed on them. Income tax is not payable except by persons with an income of over a certain figure (before the war $\mathfrak{1 6 0}$, and since the war $\mathfrak{1 3 0}$ ). But the majority of the members of co-operative societies have a smaller income than this.*

In France, the question is far more simple and would be even more surely answered in the negative for the following two reasons:-

(a) All societies, associations, corporations, \&c., are formally exempted from the general income tax, so that the question cannot be raised as regards the co-operative societies. The tax is applied to the individual only.

(b) As regards the members, it would be possible to ask whether or not they are liable at law to pay the tax on their bonuses. Then the question arises, as in England, as to whether the payment is income properly so-called, or simply a repayment, and the question might be argued for an indefinite time. In fact, however, it has little real interest because the bonuses are almost negligible in France. $\dagger$

During the war several belligerent countries, notably Germany and Italy, have limited the rate of interest which companies are allowed to pay to their shareholders, and the

"Author's Note. But this argument is now ruled out, because since the war the exemption limit was reduced to $£ 130$. There can be relatively few co-operators in England witl an income below this figure, especially when we consider the great rise in wages since the war.

+ Author's Note. But the question arises now on the new tax imposed in 1920 of 1 per cent. on the turnover (all commercial sales, not agricultural ones). As this is a question of a tax on sales, not on revenue, consumers' societies, at least, consumers' stores, eannot evade it. $A \mathrm{~s}$ for the wholesale societies, the Government wished to exempt thein because they do not sell to individuals. But owing to the protests of the traders, who are already working against this perfectly legitimate exemption, it will, probably, not be admitted. 


\section{CONSUMERS' CO-OPERATIVE SOCIE'TIES}

question therefore arises, does this apply to the co-operative societies? It has generally been decided that it does not, on the same ground that the bonuses distributed by co-operative societies are not profits.

These are not the only taxes that may hit co-operative societies; there are many others-all the ordinary duties, the tax on personal property, stamp duty on the shares issued, the mortmain tax, which falls on all bodics which do not die and therefore never pay death duties, and, if the society sells wine or alcoholic liquors, the spirit license. 'The position of co-operative societies as regards taxes generally is unsettled, not only in France and England, but in all countries. A curious example of this is found in Switzerland, where a recent enquiry showed that the taxes paid by cooperative societies vary in each canton in the most incredible way, from $\mathfrak{f 7}$ in Bâle to $£ 385$ in the Grisons!

\section{State Subsidies}

We have already said (page 113) that in France the consumers' societies, fceling more than ever the need of sufficient capital as they grew larger, turned to the government, following thereby the example given by co-operative credit and productive societies. And we see that the State did, in fact, create a fund for them of $£ 30,000$ which was distributed among them in the form of a loan.

It is to be expected that this subvention will be enlarged by degrees (as happens with all such subsidies), but it will never be of great importance in comparison with the increase of consumers' societies, and above all of wholesale societies.

During the war the State has given co-operative societies far more important advantages in the form of facilities and cven privileges for the importation, transport, and sale of various products. 
PRODUCTION B Y C ONSUM R R ' S O C I E T I E S

Section I.-Stages on the Road to Production

It is natural that as soon as consumers' societies have reached a certain stage of development they begin to consider production. This aim is shown in a remarkable degree by the name which one of the largest consumers' societies has taken, "The Produltion of Hamburg."

They first consider production solely with the wish of economizing by getting food cheaper by producing themselves the articles which they used to buy from the manufacturer. 'The very simple notion occurs to them that, after they have absorbed the profit of the retail shopkeeper and then, through the wholesale society, that of the wholesaler, they can go further and absorb the manufacturer's profit by making their goods themselves. By this means, since they control the products in all their stages, they will reach the final limit of cheapness.

But it is not only for the pleasure of reducing their prices that consumers' socicties enter production; it is because they understand that only by this means can they transform the economic organization. Whether they are inspired by the collectivists' program-the socialization of all the means of production-whether they remain faithful to the old ideas of associationist socialism, or whether, without abolishing the wage system, they only propose to raise wages by giving back to the workers the portions taken from them by the landlords and the captains of industry, in every case 
they feel the need of owning or at least controlling production. ${ }^{1}$ It would be to stop half-way and leave their work unfinished and inefficient, if they confined themselves to distributing co-operatively the wealth which would continue to be produced under the competitive system.

The humble Rochdale weavers clearly foresaw all this and pointed out the ultimate consequences of consumers' cooperative association. Readers should remember their articles of association, which we have already quoted (page 35 ), and particularly the second to last, viz.: "that as soon as is practicable this society shall proceed to arrange the powers of production ... and to establish a selfsupporting home colony of united interests." They mark out for themselves two stages they would have to reach to gain this end: "(1) The manufacture of such articles as the society may determine upon; (2) To purchase or rent an estate or estates of land which shall be cultivated"; in other words, the conquest of industry and then that of agriculture. It is true that the rules only contemplated a very modest form of production which would give employment to members who were out of work, but it is only a question of first steps. We shall consider these two points in turn.

(a) Industrial Production.-Industrial production, that is to say, the erection of workshops and factories, is difficult of achievement by an isolated co-operative society, at least unless it has many thousands of members, not only for want of the necessary capital (see page 112), but above all for want of sufficient outlet for the goods.

If three hundred families are enough to maintain a bakery it is clear that many more are wanted to employ a

1 All these motives are prevalent among co-operative enthusiasts in the United States. Probably the commonest motive is the "absorbtion of private profits for the benefit of the workers," a direct attack upon small Capitalism. The more advanced and radical of co-operators, of course, are satisfied with nothing less than the ideal of an economic order directly under the control of the organized consumers. 
factory for making boots, soap, cloth, or cotton. It is only such household necessities as were formerly, and still are, made at home in country districts as domestic industries, such as bread and pastry, pork butchery, and jam-making,* which can be attempted with success by a society with a membership of only a few hundreds, or possibly a thousand. ${ }^{2}$

But from the day when consumers' societies formed federations for purchasing, and were able to show a solid mass of several thousand purchasers, as in England, they were able to enter on large scale production without fear. The establishing of a purchasing federation or wholesale society is an almost indispensable preliminary step, and we have already pointed out, as one of its principal advantages, that it makes production possible. The English Wholesale Society, which is a unique institution, and perhaps the most remarkable economic phenomenon of the nineteenth century, has already started a number of factories, which produce articles of the most varied nature-flour, butter, bacon, biscuits, sweets, jams, preserves, pickles, chocolate, tobacco, cigars, cigarettes, soaps, candles, boots, woollen and cotton clothes, corsets, bonnets, hats, brushes, and furniture. There is a bacon factory in Denmark, and one for the production of grease from sheep's wool in Australia, and forty creameries in Ireland. ${ }^{3}$ The Scottish Co-operative Wholesale Society has also important factories, which have furnished many goods to the Russian government during the var; the two together have produced goods to the value of $£ 12,600,000$.

* Author's Note. It is curious that an essentially -domestic and very important industry, the laundry industry, has never been undertaken by consumers' co-operative societies in France.

2 'There are no wholesale productive works under the control of organized consumers in the United States except the biscuit works of the Co-operative Central Exchange of Superior, Wisconsin. Some societies have bakeries, creameries (where butter and cheese are made), etc. A few co-operatively hire a tailor to make them suits of clothes. Large scale production, however, is still in the future.

s The C. W. S. creameries in Ireland have lately been given over to the control of the Irish productive societies. 


\section{CONSUMERS' CO-OPERATIVE SOCIETIES}

Besides this, production by retail co-operative societies, which produce goods on their own accounts, reaches a total of $£ 15,550,000$, which means that goods to the value of nearly $£ 28,000,000$ are already produced by the federated or isolated consumers' societies of Great Britain (all these figures refer to 1914). ${ }^{*}$ Doubtless, these figures, though they appear large, do not represent one-third of the total goods consumed by British co-operators, they have still a long way to go before they will fulfil the Rochdale program of producing everything they consume and becoming self-supporting. But still step by step they are approaching to this ideal, for the ratio between the total production and the total consumption is rising regularly and fairly rapidly. If we take into consideration the fact that the total sales of co-operative socicties ( $\$ 88$ millions in 1914) only represents a bare $£ \% 6,000,000$ at wholesale prices (see above note, page 54), it may be said that British cooperators alrcady produce nearly one half of what they consume. Here are the comparative figures for 20 years (1895-1914):-

\begin{tabular}{|c|c|c|c|c|c|c|}
\hline \multirow[t]{3}{*}{1895} & Production & •. & . & • & . & $£ 6,000,000$ \\
\hline & Turnover & $\cdots$ & $\cdots$ & $\cdots$ & $\cdots$ & $£ 34,000,000$ \\
\hline & Proportion & $\ldots$ & . & . & .. & $18 \%$ \\
\hline \multirow[t]{3}{*}{1914.} & Production & .. & $\cdots$ & . & $\cdots$ & $£ 32,200,000$ \\
\hline & Turnover & $\ldots$ & $\ldots$ & $\ldots$ & $\ldots$ & $£ 88,000,000$ \\
\hline & Proportion & $\ldots$ & $\ldots$ & $\ldots$ & $\ldots$ & $37 \%$ \\
\hline
\end{tabular}

4 For 1918, the Staff of the Co-operative Reference Library gives the following figures:-

The two Wholesales

Distributive Societies

Productive Associations

$$
\begin{aligned}
& £ 33 \text { millions } \\
& £ 23 \text { " } \\
& £ 3 \\
& £ 49 \text { millions }
\end{aligned}
$$

* Author's Note. More than half this figure represents the production of bread and flour which, in France, is not classed as production properly so-called, but as consumption.

The total given does not include articles produced by self-governing productive associations, whose turnover reaches $£ 1,800,000$ (I slonld say that the figures vary greatly in different statistical tables because the definitions which are given of productive associations vary). If the figures for production by consumers' societies is added the grand 
Thus in a relatively short time production has increased more than five fold, while the turnover has not quite trebled. All the same, it is worthy of remark that even though production equals the turnover that will not mean that co-operation is entirely self-supporting. Industrial production is the manufacture of raw materials purchased elsewhere, the value of which naturally appears in the figures given in the table. This brings us to the necessity for cooperative societies entering into the production of raw material.

(b) Agricultural Production.-Industrial production has for its sole object the production of manufactured goods -clothes, furniture, hardware-or the preparation of food products, but these are only a part of the goods handled by consumers' societies. We know, in fact, that the greater number of these societies are grocers, bakers, or green-grocers, which means that they deal chiefly (and often exclusively) in the fruits of the earth, home-grown or imported.

The sale of coal and oil, which are also products (if not of the soil, at least of the earth), also has an important place in their sales. Therefore, if they really wish to be self-supporting they must turn towards agriculture, and even mining, and that not only on British territory, but overseas also. The English co-operative societies already sell 16,500,000 bushels of wheat, and the wholesale societies sell 1,500,000 tons of coal and 7,500,000 lbs. of tea. These figures would be more than trebled if each co-operator did his duty.

Even before the day of the Pioneers, the Congress of 1832, under Owen's inspiration, declared that it must be understood that the final aim of all co-operative societies was "community on land."

total of British co-operative production rises to $£ 30,000,000$ for 1914 .

In 1920, the figure for the two wholesales is more than 40 millions. But this increase is due chiefly to the rise in prices. 
The late war has given a great impetus to this movement, for the co-operative societies, in trying to fight against high prices and excess profits, have found themselves impotent in so far as they do not control the very sources of production-the soil and raw materials. (See in the last chapter, the tendency of co-operators towards agricultural socialism.) It should be stated that this control is not only necessary for the production of foodstuffs, but also to secure the raw materials which are necessary for industry, which also come from the soil. The English co-operative societies sell $£ 1,000,000$ worth of boots and shoes annually, but how can they reduce the price of them, since they depend on leather merchants and tanners? And what use would it be to them to be curriers and tanners, if they could not supply themselves with hides by raising cattle? And how can they raise cattle without owning land? Thus we always come back to the land.

From these considerations has sprung what is known as the Shillito League (from the name of one of the chairmen of the English Wholesale Society, who suggested it in his presidential address at the Co-operative Congress at Doncaster in 1903). The Shillito League, formed in 1915, thus defined its program. "It desires to crystallize the vague mass of thought in the movement, now in favour of co-operative ownership of the sources of raw materials. It is in favour of the purchase of large areas of land in this country, in Canada, Argentina, India, or elsewhere, that may be found necessary and desirable for the production of cattle, wheat, tea, cereals, or other supplies. . . . It recommends the purchase of coal mines or coalfields in this country, as and when favourable opportunities present themselves." 5

This ambition is not, however, confined to English cooperators. In Switzerland it is also manifest, as is shown by the program approved by the Congress at Schaffhausen

5 The Shillito League has ceased to exist. 
in 1916, by 256 votes to 105, and which is as follows:"This assembly, considering:-

(1) That it is the duty of the Union in the interests of consumers to undertake production in all its branches, agricultural as well as others;

(2) That this cannot be accomplished without the acquisition and working of agricultural lands;

(3) That this acquisition, if it is possible at a moderate price, does not involve heavy risks;

(4) That the Swiss Union is in a position to find the money for the purchase of one or more agricultural holdings without tying up its funds to the prejudice of its other branches of activity;

Authorizes the Committec to acquire one or more agricultural holdings on behalf of the Swiss Co-operative Union. For this purpose it authorizes the raising of the necessary

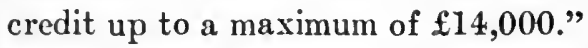

The Shillito program has already caused projects to be formed, such as the purchase of 100,000 acres in Canada, which will cost $£ 160,000$, and may bring in about a million and a half bushels of wheat; the purchase of 25,000 acres of tea plantations in Ceylon, which will partly suffice for the present trade in tea of the Wholesale Societies; and the purchase of coal mines, which was the order of the day long before the war.

The end is still far off, but the movement is slowly progressing in that direction. There are already more than one hundred socicties in England which have bought or rented 25,500 acres of land for agricultural purposes, and among them, naturally, is the C. W. S. which has seven estates (in all 32,000 acres, on which it already produces strawberries, gooseberies, tomatoes, \&c.). 'The farms are generally run as they were before being purchased by these cooperative societies, as the co-operators did not wish to dismiss the farmer. But this is only a provisional arrange- 
ment. It has also eight tea plantations in Ceylon and India, with a total area of 18,000 acres, which already produce a large part of the tea consumed by the co-operative societies. To sum up, there are already a number of English co-operators who enjoy their own tomatoes and strawberries, and drink their own tea. Purchases of land are becoming more and more frequent. We should also mention the purchase by the Wholesale Society, five or six years ago, of a forest of palm trees in West Africa (Sierra Leone), which supply the raw material for making soap. By this means the C. W. S. was able to get behind the big soap Trusts.

It cannot be said that these experiments have been very encouraging so far. The cultivation of the 14,500 acres held in 1916 yielded profits of $£ 8,863$ and a loss of $£ 5,865$, leaving a net balance of $£ 2,998$ profit, which, for a capital of $£ 427,000$, only represents $3 / 4$ of 1 per cent., or 10 s. $6 \mathrm{~d}$. per acre. The profits were higher in 1917, £32,000, and

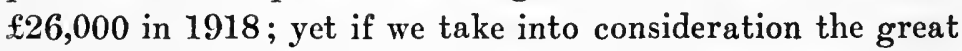
increase in area of the estates which have nearly trebled, the results are not much better. But it is a question of net profit, which is to say, that the interest on the capital of purchased estates and the rent of leased estates appear on the debit side of the balance sheets.

Nevertheless, we must acknowledge that, in all experimental work, whether in the domain of sociology or of science, the average result is a very bad test. One single success would weigh more heavily in the balance than a hundred failures. It was to be expected that the consumers' societies, formed entirely of town workmen and clerks, would be badly fitted to undertake farming. Anything else would have been astonishing; but all the same some attempts at agricultural development by consumers' societies have succeeded very well. Thus one small society with an estate of

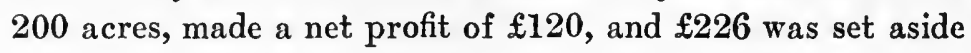


as a sinking fund. The tea plantations have also produced good results.

There is reason for thinking that one of the causes of the ill-success of many of these farms is that, like their neighbouring farms, they produce for sale instead of producing solely for their members' consumption. It is forgotten that if co-operators farm it should be not to sell the products but to eat them. The landowner who lives on his land and its products, even if he does not make much, does not lose, and lives well. This is what consumers' societies ought to do.

It has been calculated that an estate of 1,000 acres should suffice for the needs of a society of from 2,000 to 3,000 members.

(c) Public Services.-Public services, such as the working of tramways, gas and electric lighting, and above all railway and water transport, seem altogether, and for ever out of the range of a consumer's society. But why? Is it because of the large capital needed? It does not require more than the great co-operative federations possess. Is it because of their nature, which is that of service rendered, rather than the supply of material goods? Not so, for the telephone service, which is of the same nature, is worked co-operatively in many towns in the United States, as we have already said. ${ }^{6}$ Is it because it is the nature of these services to be offered to all, to be public in the broad sense of the word, and because it would not be morally or materially possible to reserve them for a group of associated persons? This reason seems no more conclusive, since we know that many, if not most, of the consumers' societies sell to the public.

The true reason seems to us to be that the public service does not lend itself to the law of gradual expansion and prog-

- In instances where these telephone societies have proved that there is a real desire or need for telephone service and that such service amply pays for itself, the private telephone corporations are now either attempting to buy up this service or they are opening up other lines in opposition to the co-operatives. 
ress-like that of all living bodies-which characterizes all forms of association. It must be born full-grown and fully armed. A tramway or city railway system is only useful if it embraces from the beginning all the principal strects of the town, and we cannot imagine it beginning in one street and then extending its lines according as members join it. This is why public services can only be created under the form of big capitalist or municipal enterprises.

But, when considered carefully, is not this last form cooperative? Is not its only object to supply as cheaply as possible the needs of consumers without seeking any gain, or if there are gains, are these not like the bonuses of cooperative societies, in the sense that they are used for the purposes of general utility or even returned to the consumers, that is to say to the inhabitants of the town, in the form of a reduction of rates? For it is obvious that if a municipal authority gains money in the form of profits from public services it has so much less to collect from the ratepayers.

We, therefore, are led to regard municipal enterprises as a form of co-operative association including all the inhabitants of a town, as private co-operation developing into public co-operation. No doubt the difference exists, which economists and individualists maintain with some heat, that is, that the so-called association is compulsory, since each individual becomes a member by the simple fact of his residencc, and his subscriptions, if they may be so-called, are taken in the form of taxation.

We do not seek to dispute this distinction, nor to consider it of little importance. Still, it may be said that there are many legal forms of contract recognized by jurists under the significant name of "contracts d'adhésion," in which free consent is presumed though not expressed; for example, the implicd condition that a tenant taking a house renders himself liable to all the rates and taxes, or a member on 
joining a club to its rules. Can it not be said that the fact of going to live in a town or remaining in it (since it is always possible to move elsewhere), constitutes a sign of adhesion to an "implied contract" of association with the inhabitants of the town, and in consequence the difference between what is called the co-operative association and what is called the municipality is one of degree rather than of kind?

This difference may well be justified by the fact that it is here a question of needs, such as light, water, and means of transport from the home to the place of work, of so universal a nature and so necessary that they may be said without exaggeration to impose themselves equally on all citizens. It is not possible to refuse them, and a refusal ought even not to be permitted. Strictly speaking, co-operation and nationalization meet (as mathematicians say of parallel lines) at infinity - whether it be a consumers' society like the Bâle Konsumverein, embracing nearly the whole population, which is a truly public service, or whether it be an undertaking, like the National Fire Insurance Company, of Saxony, administered by the insured people, which makes it literally a co-operative society.

Thus, one is led to distinguish two or even three forms of enterprise corresponding with three degrees of needs.

(a) Individual enterprise for all new needs or those which, without being new, are matter of individual taste, such as artistic industries.

(b) Co-operative enterprise for all needs of general consumption; uniform, homogeneous, but still facultative.

(c) Public municipal or State enterprise for all necessary or universal needs.

In every case, even when these distinctions seem too subtle, it is certain that co-operative societies will tend more and more to look upon municipal enterprises as their close relations, and will insist on co-operatizing them and taking 
away from them their administrative and bureaucratic character so that they may be controlled by the consumers themselves outside of political influence (this will not be displeasing to the liberal school of economists). Whenever possible, they will even call on the municipality to delegate to them the running of the enterprises.

The same conflict which we shall next discuss in other branches of production will renew itself here, for the employés of public services also seek to form themselves into co-operative associations, of production, not of consumption, and also demand that the municipalities, and the State should hand over to them the running of the enterprises.

But perhaps it will be possible to reconcile these hostile demands by the same means which we shall consider later, and that in the future we shall see the association of consumers controlling the industry for the working of land, but handing over its actual carrying out to workers' associations.

Section II.-The Conflict between Consumers' Co-operation and Producers' Co-operation

In taking up production, consumers' societies not only come into collision with private firms, but also with another form of co-operative enterprise, the industrial productive association, which maintains that this part of the work is its province. Here arise a conflict of rights which forms what is undoubtedly the most important question in our study and the most difficult to solve; for it goes to the very roots of economic science in propounding this question: "To whom does the profit taken from the capitalist belong? To the worker or the consumer?"

This book does not deal with co-operative associations for production, but it is well known that under this title is understood a grouping of workmen in the same industry who themselves produce certain goods or do certain work and divide among themselves the profits of their labour. They 


\section{PRODUCTION BY CONSUMERS' SOCIETIES 231}

are businesses which sell to the public, like any form of privately-owned enterprise, but with this essential difference, that the master is eliminated and replaced by a little republic. The types of these republics are very varied. It is also well known that this particular form of co-operative association has created great enthusiasm, particularly in France and during the revolution of 1848, and also in England among the "Christian Socialists," and that for a whole generation it was looked upon as the solution of the social question.

Finally, though they have not realized the great results expected, these associations have developed steadily, and have achieved some startling successes in various countries, particularly in France. The best known of these are the Familistère at Guise, the painting and decorating society known as Maison Leclaire, and the Joiners' Association in Paris.

Such being the circumstances, it is easily understood that the productive associations-which already had sufficient work before them in fighting the private firms-would not be very pleased to see the consumers' societies poaching on their preserves.* This so much the more since they have the same aim, namely, to gain the control of production. They further use exactly the same means as the consumers' societies, federating to suppress competition and in order to sell the goods they produce to more advantage just as the others are federated to produce better the goods they sell. This federation of co-operative productive societies already

"Author's Note. It is amusing to see in France how the productive societies despise the consumers' societies. A few years ago the official paper of the productive associations, in reporting an interview with $M$. Doumer, a propos of legislation for co-operative societies, gave the words of M. Ladousse, director of the Association of Upholsterers, and formerly President of the Council Chambcr, as follows: "Mr. I,adousse, interrupting M. Doumer, expresses the opinion that consumers' societies have a very limited social action, and that they can only be considered as a means of ameliorating the material condition of the workman by procuring goods for him, and groceries in particular, chcaper than the ordinary trader." 


\section{CONSUMERS' CO-OPERATIVE SOCIE'TIES}

exists in France under the name of "Chambre Consultative" (Advisory Chamber), and there was even an abortive attempt to create a retail store.

These claims seem absolutely incompatible, and it is not easy to decide off-hand between the two systems, for each of the two has strong arguments to bring against the other.

We shall first take the partisans of production by selfgoverning associations, which is called in England the individualist system, although it concerns associated, not individual enterprise. They say:-

(1) Associations of producers ought by their very definition to be more competent in matters of production than associations of consumers. To give over production to the consumers is asking people who know nothing to do everything; it is to do away with the laws of the division of labour and of the specialization of function, and to endanger all the economic progress which has resulted from them. Moreover, experience shows that the consumer is passive, inert, and a slave to routine, one who is backward in following technical progress and who never takes the initiative. Everything new in the industry and fashion has come from producers.

(2) Co-operative productive associations are the only means by which one can hope to realize the emancipation of the working class from the wage system; they can enable the workers to become their own employers and to retain the whole fruits of their labour. On the other hand, the consumers' co-operative movement in taking production into its own hands will only perpetuate the wage system, for workmen in the employ of a consumers' society are not in any different circumstances from those working for an employer or a joint stock company. They are, and will always remain, wage earners. It is true that they will be wage-earners employed by other workers, but what will they gain by that? 
Is it freedom? Those who have experience of co-operative societies know that a worker finds in his fellows an employer worse than a bourgeois master.

Is it pay? The worker will get no more than a private employer-perhaps a good employer-will give him. $\mathrm{He}$ certainly will not have the whole produce of his work, since from the work done by him a part equal to the employer's share will be taken from him, the sole difference being that the part which goes to the consumer will not be called a profit, but a bonus. Take, for example, a worker in a boot factory who produces goods of the selling value of $£ 120$. Whether he is working for a private employer or a co-operative society, in neither case will he get more than his wages, say, $\mathfrak{1 8 0}$, while in a self-governing productive association he will gain the profit also.

On the other hand, the partisans of production by means of federated consumers, i. e., wholesale societies (this is the system the English call federalist) have good replies to these two arguments :-

(1) It is true that the consumer is incompetent from the technical point of view, but he is not asked to make his bread or his shoes himself; it is obvious that he will have them made by persons skilled in the work. The law of the division of labour, therefore, is not infringed. The new order will simply have the effect of giving the consumer the control of the production. Besides, the fact of having as a director a man who is not skilled in the particular business does not necessarily mean inferiority. This is not a paradox. To direct a business well, it is necessary to know what is wanted and whither things are tending, but a knowledge of the technical processes of manufacture is not indispensable, still more it is not necessary to be able to do the actual work of production.

It must be admitted that in the present state of economics the consumer shows himself little apt to exercise the 
economic lordship which is proposed for him. But people, whether they are consumers or not, will do nothing so long as they are not called on to do anything. It is only now that the consumer is beginning to feel his rights and responsibilities. The consumers' leagues formed some years ago in the United States, and recently introduced into France, are a striking proof of this. The entry of associated consumers into the realm of production will be the best way of educating them both economically and socially.

(2) It is true that the consumers' society when it produces for itself does not do away with the wage system and in so far does not realize the dreams of the French socialists of 1848. But it at least abolishes the capitalist employer, and in reality that is all they wished for. The workmen employed by a consumers' society are not only in the service of their comrades, as a critic of the system said a short time ago; if they have the co-operative spirit they can become members of the society. Working for a society of which one is oneself a member is very like working for oneself; in any case it is very different from the old wage system, and it is worth noting that it has more resemblance to than difference from co-operative production, because this last nearly always finds it necessary to have resource to wage-paid work.

It is said that the workman who is employed by a consumers' society gets only his wage and not any part of the surplus, which goes into the total profit, and is then divided among the consuming members. But it is forgotten that if the worker is himself a member of the society, and if he there spends the whole or only three-quarters of his wages of

In support of this theory he cites a curious proof found in the rules of a co-operative productive society at Sens-"la Laborieuse"-an association of shoemakers, who decided that the manager should never be chosen from among the shoemakers! As a matter of fact he was a compositor. 
$\mathfrak{f 8 0}$ he can get a bonus of from $\mathfrak{f} 6$ to $\mathfrak{£} 8$, and so will find himself in the same position as a worker in a productive association, with the one difference that, instead of getting his profit in his capacity of producer he gets it in his eapacity of consumer. But what does it matter whether he gets it with one hand or the other. Is it asserted that he would receive much more in a productive society? It is not certain. We see, for example, that in England, in 1902, the 92 self-governing co-operative productive societies sold $£ 1,800,000$ worth of goods, on which they made $£ 102,400$ profit. This does not give even 6 per cent.; therefore, according to the example given above, the working shoemaker getting $£ 80$ salary, and producing to the value of $£ 120$, would only receive $\mathfrak{f} 6$ odd as profit. Now, the average rate of bonus in English co-operative societies being $13 \frac{1}{2}$ per cent. he would be entitled to a profit of $\mathfrak{f 1 0}$ odd in a consumers' society, where he could spend his $\mathfrak{L} 80$ of wages. In France, the general figures of the profits of industrial productive societies are not published, but it is unusual for their dividends to reach 10 per cent. on the wages paid.

On the other hand, the federalists, among whom are all the socialists, say contemptuously that the self-governing cooperative productive association will always be powerless to achieve a social transformation of the magnitude of the abolition of the wage system, as it can only raise a few small groups of workers a few degrees. It can remove them from the wage-earning class of small associated persons, but these scattered and sporadic enterprises will bring no better conditions to the working-class as a whole. What is even worse, it draws from the working-class movement its most intelligent and energetic members. And the history of cooperative association for production proves its powerlessness. What has it done in the last sixty years, even in France, the country of its birth? It has grouped together 
20,000 members who produce goods to the value of $£ 2,800,000$ (before the war). The results are hardly better in England, and much less in all other countries. Mr. Shillito, the president of the Wholesale Society, at the congress at Doncaster in 1903, proudly contrasted the progress of production by the federated consumers with that of production by the self-governing productive federations. If we take the last two decennial periods we shall see (replacing the figures [1895-1914] quoted by Mr. Shillito, by the later ones) that the production of the self-governing workers' cooperative societies has only risen from $£ 900,000$ to $£ 1,800,000$, * which is an increase of 100 per cent., while the production of the two wholesales, the English and the Scottish, has risen in the same period from $£ 15 \%, 000$ to

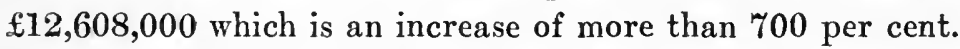
(See Reports of General Co-operative Survey Committee, 1919, page 278. $)^{7}$

Even if it were admitted that the productive co-operative societies could develop until they had conquered all industry what sort of nation would be formed thereby and with what spirit would it be animated? It would be solely animated by the individual trade interests; the general public interest would be sacrificed to the interests of the various corpora-

* Author's Note. In these statistics of self-governing societies for production we do not include co-operative mills, as these are merely dependent on the distributive societies with the object of supplying the latter with flour. Besides, in the course of this decade, they have decreased in importance, owing to the competition of the mills belonging to the Wholesale.

7 The producers' co-operatives in the United States have had even more trouble than the consumers'. At the present time there are a few of these in existence:-tailor shops, cigar factories, bakeries, etc.but the number of failures seems to keep pace wth the number of new associations that spring up all over the country. The organizers find themselves very heavily handicapped from the beginning. They cannot raise sufficient capital, they cannot find a dependable market for their product, and they cannot find workers willing to work as hard for themselves as they are compelled to work for the private corporation. 
tions. It would be the reign of competition and the struggle for profits as today, with the only difference that there would be no big employers. The amount of progress would be very small.

The federalist system has the rare advantage of being at once supported by the business men and the socialists; the business men support it because of the good results obtained, the socialists, because a social system where all production is in the hands of all the consumers associated together, and where production instead of being a separate enterprise will be organized in the form of "social service," comes at the head of all collectivist programs. If we imagine the Wholesale Society of Manchester enormously grown until it has absorbed all the manufacturing and agricultural industry of England, owning all the means of production, and elected by all the consumers (that is to say every one) we shall get a view of what a collectivist state might be, or, as the Germans call it, of a "Social Democracy."

That is why all the congresses of the socialist co-operative societies in France demand organization of production by the consumers' societies.* In fact, since the socialists give to co-operation no other aim than the socialist aim of transforming capitalist property into collective property, it is clear that a good way of coming together is for the productive co-operative societies to become the property of all the consumers. But this view is far from being pleasing to every one, and it is because of this dangerous resemblance between federalist co-operation and collectivism, and through fear of secing co-operation end in a reign of bureaucracy and centralization, that many co-operators remain faithful to the

* Author's Note. However this claim of the socialist co-operative consumers' societies to absorb the productive societies has caused quarrels with the latter, notably a disagreement with the wine sellers' associations, from whom the socialist co-operativc socicties purchased wine. 
old system in spite of its faults, that is of production by free associations of producers, federated as far as possible.

Such is the opposition between the two systems. But is it irreconcilable so that one must choose the one or the other? Should it not rather be admitted that each has its merits and that each should find its place in a general co-operative organization? We hold this view, that even if it were assumed that the consumers' societies embraced the whole population of the country and furnished it with all the articles needed for household consumption (which is far from being realized), and that all they sold was produced by their members in their own factories, many thousands of workers would remain outside the co-operative consumers' ranks as producers, namely, all the workers employed in the service of the State, the municipalities, the railways, the mercantile marine and sea fisheries, in manufacture for export and even in artistic and luxury industries which it is hardly possible, or even desirable, to bring into the co-operative form. Besides this, there are all the land workers and miners, for it can be seen, from what we have already said, that it will be a long time before the co-operative consumers' societies have bought out the land and its minerals. Therefore, in this great field outside the consumers' movement, why should not the productive co-operative societies have the right to set up an independent movement if they can?

Even in those industries which may be considered as being by right inside the economic sphere of the consumers' societies, and destined one day to be absorbed by them, why should not co-operative production establish itself temporarily in such a way that when the time is ripe it will be absorbed as an organ of the Wholesale Society?

In England, the conflict of systems which we have just considered does not prevent the most intimate relations being formed between producers' and consumers' co-operative 
societies. In fact, the producers' socicties look to the consumers' societies for:-

(1) The capital necessary for setting them up-which they would have great difficulty in finding themselves-while the consumers' societies sometimes do not know what to do with their surplus capital. That is why half the shares of the Paisley Productive Society, one-third of those of the Hebden Bridge Society, ${ }^{8}$ and six-sevenths of those of the Airedale Society belong to consumers' societics. The same is true of the Scottish societies, of which it is hard to say whether they are independent or simply branches of the consumers' societies. The German socialist, Lassalle, asked the State to provide 100 million thalers $(£ 15,000,000)$ for workers' associations, and believed that with this sum he would be strong enough to realize social democracy. The consumers' co-operative societies could place about double this sum at the service of the workers' productive associations (see page 116).

(2) Customers, which are even more indispensable to their existence than capital, and not less difficult to find. Thanks to the consumers' societies, a productive association, -for example, one of working shocmakers-knows in advance how many boots it will have to supply, and can work with a certainty of a market.

In France, things cannot be worked in the same way, for the two kinds of relationships which we have just pointed out are both almost impossible. The French consumers' societies have barely enough capital to supply their own actual needs, or else have too often locked up their capital in buildings and shops. If they are unable to supply the productive societies with help in the form of capital they are hardly in

8 The Hebden Bridge Society, which is, according to the Staff of the Co-operative Reference Library of Dublin, the oldest Producers' society in England, has recently been absorbed by the Co-operative Wholesale Society. 
a better position to provide them with customers, for the obvious reason that most of the French consumers' societies sell only groceries or bread. What then can they buy from workers' productive associations?

This is why the understanding between consumers' and producers' societies, which has often been approved at congresses, has remained until now a pious hope. One may, however, refer to a few isolated successful attempts. The workers' glass works at Albi, a workers' association manufacturing paper bags in Paris, and, in Belgium, the Weavers' Society at Ghent, have been formed by capital which has been supplied to them in part by the consumers' societies, and have more or less succeeded, thanks to the latter's purchases. Certain consumers' societies had paid temporarily 20 per cent. above current prices for bottles to keep the workmen's co-operative at Albi going when it started.

Further, even supposing the collaboration between consumers' and producers' societies were realized, this solution does not solve all the difficulties. If a sleeping partnership is formed between any consumers' society and any individual producers' society it would mean the development of anarchy in production, which would perhaps be hardly better than the existing competitive system. On the other hand, if the sleeping partnership comes from a wholesale society, acting on behalf of the local societies, the productive societies would find themselves no less at the mercy of the formidable customer than do the small manufacturers who today work for the "Bon Marche" or the "Louvre."

In short, this form of relationship necessarily implies control. The consumers' societies, in their double capacity of chief customers and chief shareholders of the producers' associations, would of necessity have a deciding influence on their actions. And though this influence might be very healthy, in that it would maintain in the workers' associations the administration they so often lack, it must still be 
reçognized that the control would be such that it would make the self-government of the producers' associations almost illusory, and would end in a state of affairs very like federalist co-operation if, for example, the consumers' societies were the sole customers of the producers' association. It is clear that this is the tendency in England, in spite of the efforts of Vansittart Neale and Holyoake in the last generation and of Aneurin Williams and the co-partnership school today. While this school wishes the consumers' societies to confine themselves to supporting the productive associations until the day when the latter are able to stand on their own feet,* the consumers' societies have, in fact, reached a higher stage of organization and federation than the producers' societies, and more often strangle them than help them. Thus in England in 1910, one of the most powerful co-operative productive associations (that of the hosiery workers of Leicester) was bought by the Wholesale, and consequently ceased to exist as a self-governing body, becoming merely a factory belonging to the Wholesale. The workmen-members protested vigorously, but the distributive societies, who held two-thirds of the shares, and gave the largest orders, voted for the transfer to the Wholesale and the working-members, who possessed only one-seventh of the capital, were unable to prevent this absorption. It has been said that it would have been better if the English and Scottish Wholesale Societies instead of building so many factories had used the same capital to finance producers' associations; but it is doubtful whether they would have obtained the same results by this method.

It seems, however, that agriculture ought to lend itself well to this form of understanding, for we have already seen

* Author's Note. Mr. Vansittart Neale said at the Congress of 1889, that the distributive societies should do for the productive societies "that which a mother does for her child-feed it, clothe it, and teach it to walk, until it is strong enough to go by itself." 


\section{CONSUMERS' CO-OPERA'TIVE SOCIETIES}

that consumers' societies have not succeeded very well in agricultural work. For this reason would they not do better to leave the cultivation of the soil to workers' co-operative societies-either by letting the ground to workers who would become a farmer's' co-operative society-or even by helping them to form themselves into co-partnership associations? There would still be a great difficulty to overcome, because if these agricultural co-operative societies had to send all the produce of their farms to the consumers' society they would be at its mercy, since it could fix whatever price it wished and if, on the other hand, the agricultural co-operative societies had the right to sell in the open market, the consumers' society would hardly have any advantage in supporting them.*

What is to be done to settle this difficult question? Let

* Author's Note. Co-operative societies for production, which are not at all numerous in industry, can, on the contrary, be counted by the thousand in agriculture, but they are very diverse in their nature. 'Thus, there are:-

(a) Agricultural Credit Societies, which have no connection with the distributive co-operative store;

(b) Agricultural Purchase Societies (called syndicats agricoles in France), which resemble the distributive societies in the sense that they also buy to distribute among their members; but that which they buy is destined for agricultural production, and not for personal consumption. They bear no relationship to our consumers' societies;

(c) Agricultural Societies for Production and Sale, which are still less common, except in the matter of butter production. It would seem natural that the distributive societies would combine with them by buying the food which they produce, butter, wine, vegetables, \&c. Nevertheless, repeated attempts in this direction have failcd. This may be explained by the fact that these cooperative societies are composed exclusively of country landowners, and are thereby completely outside the industrial and co-operative movement;

(d) Co-operative Farming Societies, formed by agricultural labourers, who combine with the object of working collectively some land which they buy or rent. These are still in an experimental stage. However, these collective farms (affitenze collective), are fairly numerous in Italy. In England, there are also some hundreds constituted under the recent legislation for the development of small holdings and allotments. 


\section{PRODUCTION BY CONSUMERS' SOCIETIES}

producers' and consumers' co-operation develop freely, each in its sphere, even if the two spheres seem to overlap; by inter-penetration they will end by forming a single whole.

It is noteworthy that, by following the natural law of their development, these two forms of co-operation approach each other so nearly that in the end it is hard to distinguish the one from the other. If, on the one hand, the consumers' societies open workshops for the production of their goods, productive societies also can open shops for the sale of their products. If the consumers' societies give their workers a share in the profits, producers' societies in England give their customers a share. Then, suppose on the one hand a consumers' soeiety which halves its profits between its purchasing members and its workers-and on the other hand a producers' society, which also divides its profits, half to its working members and half to its customers (which are perhaps themselves consumers' societies)-are they not almost the same? It is on these lines of convergence that both producers' and consumers' societies should be guided. With regard to the workmen's share in the profits of consumers' societies, see the following chapter. As regards the participation of customers in productive societies there are many examples in England. Besides, the large Insurance Companies have led the way in this respect. In Ghent the productive society called "le Tissage (weaving) Coopératif" assigns

In France there were none of these societies up to the time of the war, lut a certain number have just been started in the regions invaded by the enemy and now liberated. In districts where the land has heen so ravaged that no buildings remain, where even the boundaries of the fields cannot he distinguished, and, morcover, where capital and agricultural implements are very scarce, it is obvious that collective cultivation will be the most economical.

Of these four forms of co-operative agricultural association it is the last which is aimed at in our text, as it is the only one which can solve the problem of an entente between the distributive co-operative society and the productive society in the domain of agriculture, if these productive co-operative societies hecome purveyors for, and in some form the tenants of, the consumers' societies. 'The practical difliculty which we note above remains in any case. 


\section{CONSUMERS' CO-OPERATIVE SOCIE'TIES}

35 per cent. of its profits to the working members, and 25 per cent. to its customers.

Thus, these two great co-operative movements, although they have started from opposite poles, can unite on a higher plane which, while giving the consumer that control which the logic of his economic conditions assigns to him, will ensure to the working producers greater independence than they now have, and above all, the precious feeling that they are controlling themselves, that they are working for themselves, and that they gather all the fruits of their labour to which they are entitled. The realization of this harmony is the more probable, since there is no doubt that it will be the same persons who form both organizations, but in different capacities. 
TIE EMPLOYÉSA N W OKM E I N C O OPERATIVE SOCIETIES

It might be supposed that this chapter deals only with questions of internal order which are merely of interest from the point of view of the good administration of societies. On the contrary, however, we have here one of the most vital points with regard to the future of co-operation, because herein are opposed two antagonistic conceptions, which may be called producers' socialism and consumers' socialism. This antagonism is manifested by the conflict, which exists in a more or less latent condition between the co-operative movement and the syndicalist. In her book "The Co-operative Movement in Great Britain" Miss Potter (Mrs. Sidney Webb) foresees the advent of this régime, in the aspect of two federations, one, that of consumers in their co-operative societies, the other, that of producers in their trade unions, and the equilibrium maintained by the balance of these two antagonistic powers. We must add that this equilibrium would be much better realized if every person were a member of the two organizations, co-operation and trade unionism, as this conflict would therefore not be on the surface, but in the conscience of each individual.

\section{(1) Conflicts Betzeen Co-operative Socicties and their}

\section{Employés}

The question of the relations between the societies and their employés does not become very acute as long as the societies limit themselves to retail trade and consequently employ only shop assistants, who are somewhat above the 


\section{CONSUMERS' CO-OPERATIVE SOCIETIES}

level of the ordinary working class. But from the time that societies engage in production, and have therefore to employ manual labourers (who are generally trade unionists), the situation becomes critical. In England the number of wageearners in 1917 was 162,000 , of whom 101,000 were employed in shops and 61,000 were employed in factories. ${ }^{1}$ If we only consider the shop employés, we see that the figure 101,000 represents 1 employé for 37 members, i. e., for 37 families and for $£ 1,420$ of annual sales. This proportion does not seem excessive, but it might still be reduced by the fusion of societies ( see page 186).

The problem presented here is similar to that of the relations between the State and its employés, which has already caused very grave trouble in France and elsewhere, and which will become increasingly menacing to the nation.

Syndicalism regards every labourer as a person exploited and every employer as an exploiter, and the syndicalist is not disposed to make exceptions in the case of people employed by a co-operative society, or by a co-operative wholesale society. Syndicalism does not renounce for them either the class war or the weapon of the strike. It wants wages to be as high as possible, even though this rise in wages can only be procured by an equal rise in prices.

Co-operation, on the contrary, regards the consumer as the person exploited, and wishes to free him. It recognizes no class war, because in its very definition the function of the consumer is independent of all class distinction or of sex. It strives to realize cheapness by reducing the cost of production to a minimum.

We might suppose that the relations between the co-operative societies and their employés would be facilitated by the fact that both belong to the working class and should

1 By the beginning of 1921 these figures had risen to a total of 201,500 , of whom 114,500 were employed in distribution and 87,000 in production. 


\section{EMPLOYÉS AND WORKMEN}

therefore look upon one another as comrades. But such is by no means the case, as, on the one hand, labourers, when they have control of an enterprise, of ten display more harshness than middle-class employers, and, on the other hand, management committees of co-operative societies, being composed of workmen absolutely ignorant of everything out of their own particular line, do not inspire their employés with the same respect as a middle-class employer, whose capability is beyond question. This fact frequently results in strained relations. Moreover, those who are not well disposed towards the co-operative movement do not miss a chance of stirring up the employés and the workmen against the societies. Thus, the important liberal and economic paper, Le Temps, in reporting the Co-operative Congress at Rheins in 1913, concluded as follows: "Seeing how cooperative societies-which are the embryo of the new social order-treat their employés, workers can appreciate the degree of liberty which would be theirs, when these societies are firmly established."

These two tendencies are antagonistic in their aim, and it is almost inevitable that this opposition should show itself in practice.

Trade unions demand of co-operative societies:-

(1) The maximum wage for their workmen, that is to say the trade union wage.

(2) The minimum working-day.

(3) The exclusion of workmen other than trade unionists.

They complain that these conditions are accepted by only a relatively small number of societies.

However, co-operative societies as a general rule try to satisfy these claims--the first and second, at any rate. All those of socialistic tendency, and the majority, even when neutral, make a rule of ensuring to their workmen and employés the most favourable rate of pay suitable to the economic conditions in which they are obliged to live. And 


\section{CONSUMERS' CO-OPERATIVE SOCIETIES}

they almost always give a higher wage and fewer hours of work than their commercial competitors. ${ }^{2}$ Doubtless, there are some co-operative societies which are no better in this respect than private employers, but unjust generalizations are made, for example, that in a Congress of the Social League of Buyers (Ligue Sociale des Acheteurs) by M. Brunhes: "Co-operative societies do not trouble themselves with the conditions of work and workers' wages."

Co-operative societies, however, cannot undertake to pay the trade union wage, or keep their shops open only eight hours a day, where such conditions would not permit them to compete with the ordinary traders and would oblige them to shut their shops. It would be acting contrary to the interests of the working-class to ruin co-operative socicties by trying to obey the mandate of the trade union. Indeed, even in the cases where they are unable to pay the trade union wage, co-operators try at least to ensure the minimum wage. And they generally allow the same pay to women as to men for equal work. In England, the question of a minimum wage has often been discussed at Congress, 24s. a week being proposed as reasonable, and this was a minimum frequently applied in practice before the war.

But if co-operative societies generally pay their lesser employés and their women employés higher than the current rate, they pay their higher officials very much less. Cernesson has remarked, with reason, that this is a grave danger to the societies, because their higher employés are tempted to leave them and go to their competitors. But we can understand that workmen who are members of co-operative

2 This is also true of the vast majority of the societies in the United States. There are enemies of the Co-operative Movement among syndicalists or communists who insist that the co-operatives exploit their employés after the fashion of the capitalists. But in the face of such keen competition by the private merchants, the co-operatives cannot always afford to improve upon prevailing wage rates, hours of labour, and all other conditions of employment at one and the same time. 
societies will not be willing to give their enployés higher salaries than they earn themselves.

They consider it, then, very unjust that their workers should go on strike, particularly on sympathetic strikes, that is to say strikes declared without grievances against the co-operative societies, but merely to support a strike against traders or manufacturers. This is what happened in Paris a few years ago during a strike of bakers' operatives. The working bakers of co-operative societies were forced to abandon their work, much to the indignation of co-operators. The latter said, quite rationally, that it was not only a blow against the interests of the working-class (as co-operative societies are formed, in fact, by workers for workers), but also an error in tactics, as it would have been of great service to the strike itself for the co-operative bakeries to have remained open, if only to provide bread for the strikers.

The third demand of the trade unions has been admitted by some socialist co-operative societies, but has been disregarded as a rule. Would it suffice, then, to reply to the trade unions thus: Make it obligatory on every trade unionist to join a co-operative society if there is one in his vicinity? Certainly not! Then why ask co-operative societies to do for the trade unionist what the trade unions will not do for them?

The two organizations must recruit by their own methods, but they need not play the part of reciprocal recruiting agents.

It goes without saying that if co-operative societies must not compel their employés to join a trade union they must not prevent them from doing so, as many employers still do. Employés must have full liberty in this respect.

But co-operative societies must somewhat regretfully admit that their employés sometimes form a trade union composed solely of co-operative employés. Such an organization is obviously abnormal, because a trade union is by its 


\section{CONSUMERS' CO-OPERATIVE SOCIETIES}

very definition a "professional" association, but a distributive society is not a professional one. It is quite permissible for employés of a co-operative grocery to join a trade union of grocers' assistants, or a baker from a co-operative bakery to belong to a trade union of working bakers; but if they band together among themselves and not with comrades of the same trade, it is obvious that they are associating against the co-operative societies. Such associations are being formed in various countries, and their very existence reveals the antagonism to which we have already drawn attention. In England, the A. U. C. E. (Amalgamated Union of Co-operative Employees), created in 1891, comprises more than 50,000 employés, ${ }^{*}$ and makes terms with the societies with ever-increasing success. Things have come to such a pass that co-operative societies have had to organize and constitute a defence fund, to resist the pressure of the employés union.

Meanwhile, there is a permanent Conciliation Board, composed of representatives of co-operative societies and the trade unions, whose office it is to smooth over the disputes between the societies and the employés; but it is not obligatory for either side to have recourse to this Board in case of trouble.

\section{(2) Means of Reconciliation}

Three methods have been tried-

\section{(a) The Member-Employé}

Would not the simplest method of reconciliation be to

* Author's Note. Exactly 51,399 at the end of 1915; there were only 2,179 in 1896 . This is a very formidable growth in twenty years. They have an income of more than $£ 40,000$, used for the service of their members, which proves that these employés are not too badly paid. Nearly one-fifth of the employés are women.

In France, or at least in Paris, there is also a trade union of cooperative employés, but on a smaller scale. 
make it obligatory on every co-operative employé or workman to join the society? Then, having become his owen $\mathrm{em}^{-}$ ployer, there would be no further opposition of interests; he cannot fight against himself. Or, rather, there would no longer be employer and employed, but only workers, each having his own task, and all being equal.

Unfortunately, the solution is not so simple as it appears. Co-operative societies have taken two or three opposing views of this question; obligation, refusal, liberty.

One section, that of the socialist type, has adopted the first solution. Their employés are recruited from their menbers, or the condition of membership is imposed.

But a large number of other societies, and among them a few English societies, demand, on the contrary, that their employés and workmen shall not be members (admitting, of course, their right to join any other society existing in the neighbourhood). They consider it incompatible for one to be a member and an employé at the same time. And it must be admitted that, if this exclusion appears irrational and surprising from the point of view of co-operative doctrine, from the practical point of view it has many solid arguments to uphold it. In the first place, if an employé is a member of the society, there is a danger that discipline and authority (both indispensable to efficient business working) may be seriously compromised, as all members are equal in fact and in law. If the manager has any remarks to make or objections to offer to the employé the latter may answer that he has equal rights and authority with the former; and even if he is dismissed as an employé, he cannot be dismissed as a member.

Further, if the employé-salesman is also a purchasing member, if, consequently, he sells to himself, there is always

The same exists in Germany; and there is also a Board of Conciliation, which collects information relating to the rate of pay, and strives to get the highest wage put into force. 


\section{CONSUMERS' CO-OPERATIVE SOCIETIES}

a certain temptation here to illegal transactions. If, also, in addition to this, the employé becomes adninistrator, and as such is called upon to control his own actions, it is clear that such a confusion of rôles is dangerous to the working of the business. Apart from all suspicion of dishonesty, the presence of employés at general meetings, with the right to vote and the right of election to office, is calculated to complicate the task of administration to a considerable extent. It may be said that the number of employés is very small in proportion to that of the members, and that consequently their presence at general meetings would not cause any serious inconvenience. This may be true, but very probably these employés will be the most assiduous in their attendance, because they will always have some grievances to bring forward. And if it happens that the ordinary members are, on the contrary, unenthusiastic, as is frequently the case, it may be that the measures which are passed at the general meetings will be much more favourable to the interests of the employés than to those of the society.

These arguments, however, do not appear to us sufficient reasons for refusing to the employé the common right to join the society or not, as he may wish. To refuse it might make him suspicious, and prejudice him beforehand against the society. And if we object to the employé selling to himself then we should have to refuse him the right of buying in the shop, even though the shop be open to the public, which would be somewhat drastic!

And as for the presence of employés at meetings, apart from a few drawbacks, this might have a good effect. It is unquestionable that any business in which those who must be subordinate are themselves in control requires a high standard of education and morale among those controlled; but it is just such a spirit that co-operative societies should strive to create and to foster. Instead of belicving that the dual 
rôle of member and employé might lead to fraud, we should regard it with optimism as a safeguard, because any trickery will rebound on the employé-member in the form of a diminished dividend.

Between these two directly opposing views with regard to their employés-obligatory membership or prohibition-the majority of societies have simply adopted the policy of leaving them free to act in the matter as they choose, and this is, in our opinion, the wisest course. It is the same as we adopted in the analogous questions as to employés joining a trade union or not.

'The question becomes more delicate when it is a matter of the employés becoming members, not only of the society, but of its management committee. We are of the opinion that if the right of an employé to be a member be admitted it would then be impossible to refuse him the right of election as administrator, on condition, however, that a limit should be put to the number of places reserved on the committee for employés; because while it is fair, and even advantageous to the working of the society, that employés should take part in its administration, it would be inadmissible for the society to be rum and governed by its own employés-the society does not belong to them.

There are some socialist co-operative societies which allow their employés to serve on their committee even though they may not belong to the society. The right thus recognized is founded solely on their quality as workers, and not as members. The Socialist Co-operative Congress at Amiens in 1912 declared "that the most extensive collaboration should exist between the management committee and the employés of a co-operative society, that these latter should always be able to take effective part in the committee of management and control, and to have representatives on the same, with right to vote." The consumers' society of Geneva has 


\section{CONSUMERS' CO-OPERATIVE SOCIETIES}

lately (July, 1919) rejected by an enormous majority the claim of its employés to be admitted to its management committee. It is true that the societies which confer this right on their employés, generally make them pay rather dearly for it, by imposing some hard obligation on them, such as making a minimum of purchases at the store, higher than that of the members' average, generally also the obligation of joining some trade union or other, of becoming a member of the socialist party, or even (we have ascertained this fact) of refraining from attending church! It is the same principle as that by which the officials and employés of the State claim the right of being represented on public and governmental committees. And we believe that for these latter this innovation would be favourably received and that public administration generally would gain thereby. But with regard to the administration of co-operative societies it would be otherwise. It seems unreasonable that an employé who shows so little interest in the society that he refuses to join it, should be granted the right to govern it. Besides, such a proceeding is absolutely illegal, and a society acting in such a manner ceases to have any status as such. As a matter of fact, in a society with share capital the meeting has no right to elect non-members as administrators. And, moreover, if non-member employés take part in a general meeting and vote, the meeting and its decisions are rendered null and void.

\section{(b) The Profit-Sharing Employe}

Another means proposed for establishing a lasting settlement between the co-operative societies and their employés is participation in the profits, as in other businesses, between employers and employés. We know the history of that institution, which during a whole generation had appeared as the solution of the social question, but which is rather discredited today. It has, however, retained very 
warm defenders, particularly in the co-operative world. It is the essential principle in the school, called in England Copartnership." However, we should say that of all forms of business, consumers' co-operation is that in which profitsharing is the most out of place. We might say even that it is absurd to speak of "participation in profits" in businesses which by their very name prohibit profit-making. That in a private business, a joint-stock company, or even in a cooperative productive society, the workman should receive a share in the business profits, as does the capitalist, is well and good. But we know that the aim of the consumers' society is precisely the elimination of profits. It gives none to its share-holders; what it distributes among its members is simply the savings effected on their purchases. What claim could the workmen have on these sums thus returned to purchasers? They have not come from the hands of workmen, but from the buyers' pockets. And further, if the society is one whose rules prohibit the individual distribution of dividends even to its members, why then should it do so to its workmen?

From the practical point of view, the introduction of

* Author's Note. Even the International Co-operative Allance, when it was first formed, had as its principal ohject the propagation of profit-sharing in the co-operative world. It was the ideal of Vansittart Neale and Greening, which they had imbibed from the Christian Socialists (page $3 \%$ ), and it was that of Charles Robert and de Boyve in France.

As for the English Wholesale, it refused point blank to apply profitsharing to its 21,000 workmen or employés, either under the form of co-partnership or that of profit-sharing. The majority of English co-operative societies also refused; only 141 (that is about one-tentli) put it into practice. They say that their members are also workmen, and that it would not be fair to take away part of their dividends, to give it to the employés.

A man who managed the co-operative society at Geneva for a long time, and whose name is well-known in Swiss co-operation, Edouard Pictet, wrote to us several times that he had instituted profit-sharing amongst the employés of his society, but that if he had to begin again he would not do so, as the results obtained were nil, from the point of view of work produced. 


\section{CONSUMERS' CO-OPERATIVE SOCIETIES}

profit-sharing in consumers' co-operative societies is still less to be recommended, because this participation, which could only be worked by a deduction from the dividends, will inevitably effect a reduction in these, and thereby hinder the development of co-operation itself.

The supporters of profit-sharing say that, by stimulating the interest and zeal of employés and workers, it will finally result in the lowering of the cost of production and an increase of dividends for all. But this theory seems optimistic if we remember, on the one hand, how little profit-sharing finds favour with the workers in general, and, on the other, how small is the increase in salary resulting therefrom. In English societies where they practice profit-sharing it only means an average of 5 per cent. on the wages, that is to say, not quite half the average dividend on purchases, which is $\mathbf{1 3}$ per cent. But these objections are aimed principally at the ancient system of division of profits, that is simply a "spice to wages," as M. LeroyBeaulieu has it.

Now, what the English school of co-partnership recommend-what they understand by the word-is not simply profit-sharing, but what we call shareholding by employés (we say in France, actionariat ouvrier), that is, the participation of the workmen or the employé, not as a wage earner, but in the capacity of co-partner. This was in practice lately is the Co-operative Wholesale Society in Glasgow, but has recently been abandoned.

Co-partnership takes for granted that the workman or employé not only may but should become shareholder-but it is not a question of shares which he may acquire like any outsider as a consuming member (if the society is not one which prohibits its employés from being members); it is a question of a new kind of shares, working shares, which give him the right to part profit not as consumer, but as a producer; the two capacities, of course, may be combined. 
And as for the objection that there can be no question of profit-sharing where there are no profits, this does not apply here. In the case of profits or savings, of "divi," as the English say, or "ristournes" as the French say, it always means that an advantage has been gained, a production in the economists' sense of the word, that is, a creation of service or utility, which is due to the combination of three factors, labour, capital, and custom. It is then only just that each of these should have its share. Co-operative enterprise should set the example of such equitable distribution. $^{3}$

\section{(c) The Responsible Manager}

Finally, there remains a third method of settling the disputes between co-operative societies and their employés, namely, that of making the employé-manager semi-independent, but responsible. We must admit the somewhat humiliating fact, that co-operative societies have only borrowed this mode of procedure from those whom they are out to eliminate, that is, the traders.

We know the three stages of the evolution of trade in recent times: The small shop, concentration by the large establishment, and decentralization by means of branch houses. The large shop. strange to say, seems unable to get beyond a certain limit, owing to a curious economic law. We are taught that the general expenses decrease in proportion to the increase of business, and that therein lies the superiority of production on a large scalc. But experience shows that on reaching a certain point, the reverse is the case, that the cost of general expenses, instead of diminishing, goes on increasing so much, that it is not always an

3 There are, at the present time few socicties in the U. S. which share the surplus-savings with employés, although provision is made for such action by the law in some states. We do know of one society, however, which divides its surplus (when it has any) between its consumer members, its employés, and the producer members from which it buys goods. 
advantage, and may sometimes even be a disadvantage, to enlarge the shop. ${ }^{4}$

Therefore, to surmount this difficulty the branch establishment has been instituted; this means that the large shop spreads itself out in branches, and that instead of trying to attract the customer to itself, it goes out to meet him. The practical difficulty was to control the branches. With this object in view, each branch manager is held responsible for the goods he has in stock; if there is any shortage, he must make good the value of the same and has to deposit security for such an event. $\mathrm{He}$ is paid according to his sales. This system of control has been so efficacious in practice that it sometimes occurs that a branch manager is ruined, the head establishment gaining thereby, and thus the latter has in the system a source of supplementary profits.

Co-operative societies have been able to learn wisdom by these lessons. They have endeavoured to keep up with general trade in the co-operative movement, by passing through the two successive phases of concentration and expansion, both centripetal and centrifugal:

First, by uniting in one single society all the societies scattered over any one locality. Thus, in England and in Germany, they have been able to form colossal societies ( see page 186, The Conflict Between Co-operative Societies and Traders).

Secondly, by creating round these gigantic societies a large number of branches. To do this, it only means that

4 Recent studies made by O. T. Hopkins for the Co-operative Union show such a tendency. A survey of many societies having an average membership of 501 members shows that the sales per member and the wage rate per pound of sales are very favourable; for other societies with an average membership of 4975 the figures are not so good; and for a third survey of societies with an average membership of 14,993 the figures are poorest. The large societies have an advantage over the small ones only in proportion of total overhead to gross sales. 


\section{EMPLOYÉS AND WORKMEN}

the pre-existing societies should be kept up-in order not to disturb the habits of their members and perhaps risk losing them-and open new shops in any district where they can count on a sufficient number of members. In this way some large co-operative societies have as many as three or four hundred branches.

But the dispersion of employés in these small branches -where sometimes there is only one person to look after the shop-has the inevitable result of making surveillance difficult and even illusory. The methods we have just detailed-of making the employé who sells a member or a profit-sharer-would not be a sufficient guarantee for the socicty against the misdemeanours or the carelessness of the employé. But, by the institution of the responsible manager, the interest of the society is bound up with that of the agent. It is to his interest to sell as much as possible-as his salary depends thereon-and to reduce to the minimum the leakage for which he is held responsible. Thus, the employé ceases to be merely a paid official, and becomes an independent contractor, with this difference only that he may not fix the prices of the goods himself.

This system gives security to the society and at the same time freedom to the employé in his work.

When the branch is important enough to require several employes, then the individual agency is replaced by the collective agency. This means that all the branch employés form a sub-co-operative society responsible to the parent society. It is somewhat the same system which in industry is called "commandite d'atelier" (collective piecework) - a number of workmen contract with a firm for the execution of a certain job inside the factory.

We must confess that in thus sceking its guarantee and its motive in personal interest co-operation is relying on the very principle which its mission is to abolish. Doubtless, 


\section{CONSUMERS' CO-OPERATIVE SOCIETIES}

this is an inconsistency; but no institution, however revolutionary, can change surrounding conditions without taking these conditions as its starting point.

For the rest, while borrowing this system from the traders' standard co-operative societies have striven to deprive it of everything which made it a means of exploitation for the profit of the parent society. A sufficiently generous margin of waste has been fixed so as not to strangle the manager, and in any case a minimum salary is ensured for him. ${ }^{5}$

5 Co-operatives in the United States have not yet reached this stage of development. There are many societies which operate branch stores, but these branches are still directly under the control of the Board of Directors for the most part, or of the Manager. We do not know of any stores operated under such a contract system. Usually the man in charge of the branch is one who has been trained in the parent store, is a co-operator with a sense of loyalty to the society as a whole, and he is given much greater freedom than the manager of a private chain store enjoys. 


\section{H A P T E R X VII}

CO-OPERATIONANDSOCIALISM

The term co-operation, when it was first employed by Owen and his followers to describe a new social order, was synonymous with the term socialism, or rather (for in those days even socialism was very little known) with communism. It was the opposite of competition for the followers of Owen in England just as it was for the followers of Fourier in France. Until the seventies of the last century the histories of the co-operative movement and of the socialist movement were indistinguishable from one another.

But at this period a cleavage took place. We may say that the Marxian socialism which then appeared on the scene was a new type of socialism altogether. The characteristic mark of this form of socialism was that it was essentially a conscious class movement of the workers based upon the theory of a surplus value created by labour and absorbed by capital. Its program was class warfare, and its ultimate aim revolution. This socialism naturally found very little of value in co-operation, since the two movements were in direct opposition to each other on all these points. The cooperators were not interested in the exploitation of the workman in so far as he was a producer, but rather in so far as he was a consumer. They never made, and never could make, any distinction between classes, since the function of consumption is just the very function which is common to all men without distinction.

Finally, co-operation aimed, not at confiscating capital which has already been amassed, but at building up a new capital by gradual and peaceful methods. 


\section{CONSUMERS' CO-OPERATIVE SOCIETIES}

Co-operation was therefore considered as a bourgeois weapon and, while they did not deny the material advantages which it could bring to the working classes, the socialists set themselves to make little of them as being of a sordid character. ${ }^{1}$ Jules Guesde said in speaking of them: "Socialists are not prepared to sell themselves for a mess of pottage." However, the example of the Belgian socialists taught them to appreciate these advantages more highly, and they went so far as to tolerate, and even to advocate, the formation of consumers' co-operative societies, but only on condition that these societies were simply subordinate cogs in the machinery of the Socialist party, whose chief function was to get now members for that party, and to furnish it with funds in ordinary times and with bread in times of strikes. As a result of this policy they have been accused of trying to make co-operative societies the milch cows of socialism.

Advocates of co-operation in every country naturally protested against attempts to reduce their movement to such a position and claimed for it the right to maintain its independence as a separate movement, seeking and accomplishing its own objects by its own methods, and not serving merely as a weapon in the hands of socialists and syndicalists.

This must not be taken to mean that true co-operative enthusiasts do not consider themselves to be socialists also. A program such as that which we have described-the abolition of profits, control by consumers and organization of production with a view to supplying the wants of the people rather than with a view to making of profits, the

1 Industrial Unionists, Syndicalists, Communists, and even Socialists in very many cases have generally belittled the Co-operative Movement in the United States also, and for much the same reasons. The economic theory of all such radical schools here is rooted in the Marxian doctrine that all exploitation is of the wage earner, at the point of production. 
transference of the control of industry from the hands of the capitalists to those of the consumer-cannot be called by any other name than that of socialism, and certainly its opponents are not sparing in their use of the term. But the socialism of the co-operative school is of a brand different from that of the others, and a brand which they desire to maintain. In France, it draws its inspiration from the old school of French socialism which existed in 1848 , and it has remained idealistic and flexible.

This claim on the part of the co-operative movement to independence has given rise to lively controversies in every country, but in none more than in France. For 17 years, from 1895 to 1912 , this quarrel filled the columns of our co-operative papers and occupied the attention of all our congresses. Working-men's co-operative socicties were against middle-class societies, socialists against ncutrals, red against yellow, the school of St. Claude against the school of Nimes, and these impassioned controversies, which today are happily only a historical memory, will always remain an instructive chapter in the history of co-operation. ${ }^{2}$

In the long run the school which claimed independence for the co-operative movement proved victorious. It had obtained vigorous support in England, in Switzcrland, and even in Germany, though in the last-named country the connection between the Co-operative Federation in Hamburg and the socialists (the Social-Democratic party as it was

2 Our Co-operative Movement in the United States has not seen such heated controversies yet. These quarrels have been the cause for repeated disruption within the ranks of organized labour and the radical political parties; but neither the consumers' nor the producers' co-operatives have ever been strong enough here to cause any great alarm among the other radical movements. We see the first indications of these only within the past two or three years. The greatest eause for controversy within the co-operative fold is the question of centralization vs. loeal autonomy within the federation or the conflict between the producers and the consumers' schools. 


\section{CONSUMERS' CO-OPERATIVE SOCIETIES}

called) was very close. It was formally approved by the International Socialist Congress at Copenhagen in 1910, when a resolution was passed, which, after paying tribute to the advantages "which are not of a material character only" obtained by co-operation for the workers, ended as follows: "The working class in its struggle against capitalism has a vital interest in seeing that workers' unions, co-operative societies and the socialist party, while pressing their individual identity, shall be united by a relationship which becomes increasingly close day by day." *

The Congress of the International Co-operative Alliance, which met some days afterwards at Hamburg, ratified this declaration, and it served also as the basis for the establishment of unity in France, which, as we have already said, took place two years afterwards, in 1912. The most advanced spirits in what was called the bourgeois movement and the most moderate ones in the socialist movement found no difficulty in coming to an agreement on a common program, which was in effect nothing more than the classical program established by the Rochdale Pioneers, described in detail in this book, with a few modifications which the development of social methods naturally suggested. The following is the text of this historic document, or at least of the declaration of principles which is the essential part thereof :-

* Author's Note. It should be noted, however, that the declaration is to some extent weakened by the following reservation, "Seeing that co-operation standing by itself would not be capable of achieving the end aimed at by socialism, that is to say, the control of government for the collective use of instruments of production, this Congress, while warning the workers against those who claim that the co-operative movement in itself is all that is required, declares that the working-class luas the most vital interest in using the co-operative method as a weapon of class warfare."

This qualification seems to have particular reference to our program. Indeed, we have frequently claimed that co-operation is sufficient in itself, not that it sees in the movement a panacea for all social problems, but in the sense that its means are sufficient to achieve its own end, which is limited to the "betterment of the people." 
"The Co-operative Union and the Federation of Co-operative Societies, being desirous of putting an end to a division of forces which affords a pretext for too many societies not joining either one or the other of the two existing organizations and thus keeps back the progress of the co-operative movement and prevents it from producing in France results as good as it produces in other countries;

"In accordance witl the essential principles of co-operation as they have been formulated by the Rochdale Pioneers and since applied with growing success by millions of workers in all countries, that is to say:

"(a) The substitution for the competitive and capitalist régime which now exists of a state of society in which production will be organized with a view to meeting the needs of organized consumers, and not for the purpose of making profit:

"(b) The gradual and collective control of the means of exchange and production by the organized consumers, who will thereafter enjoy the benefits of the wealth which they themselves have created:

"Acknowledging the harmony between these purely cooperative principles and those which are incorporated in the program of international socialism, but claiming, in accordance with the decisions of the Congress of Hamburg and Copenhagen, that the co-operative movement shall preserve its independence:

"Leaving, moreover, to each socicty absolute freedom to dispose of its profits according to its own will, with the sole exception of societies of capitalists or employers, that is to say those which allocate to their shares a dividend in excess of a certain fixed rate of interest, or which limit the number of their sharcholders, or give their members votes in proportion to the number of their shares, or which do not admit the absolute sovereignty of the general meeting of the members : 


\section{CONSUMERS' CO-OPERATIVE SOCIETIES}

"Hereby decide to dissolve the existing central bodies and to replace them by a new body which shall be called the National Federation of Consumers' Co-operative Societies, the Organ of Emancipation of the Workers."

But though the co-operative societies have given up their claim to swallow the neutral societies, there still remains in the co-operative world, and particularly in France, in spite of the union which has been achieved, a considerable divergence of policies which is exemplified by various types of societies.

These may be grouped in three divisions; the individualist school, the socialist school, and the school of co-operation pure and simple.

\section{(1) The Individualist Type}

In France, this type of society is also called by the name of bourgeois society. It is necessary to define what is meant by this term. As a rule the socialists apply this qualification to certain societies, simply for the reason that they number among their members, or on their committee, people of the middle classes, officials, small capitalists, and clerks, or because their members belong to the Conservative party in politics, or profess a certain religious faith, or because they do not contribute to strike funds, \&c., in fact, it is the general attitude of the members against which the indictment is brought.

But if we are to give this qualification a really scientific significance it must be applied only to those societies which seem to be, more or less closely, societies of a capitalist type of organization, and which have no other object in view than the personal advantage of their individual members. Among these are the following:-

(1) The societies in which the profits are allocated to capital, that is to say, divided among the members in propor- 
tion to the number of their shares: ${ }^{3}$ Of such a nature is the Civil Service Stores in London. This society, which incidentally is the largest of all the English societies as far as number of members and turnover is concerned, divides its profit solely among those members whe are shareholders, (ordinary associates of the society merely pay a small entrance fee for the right of purchasing) and since its principle is to sell very cheaply, while the number of its members who hold shares is very small and its turnover enormous, it can distribute large dividends, and its shares are quoted at a considerable premium.

There are other societies in London organized on the same basis, one for the officials of the higher grades, one for officers, \&e., but they are not reckoned among the co-operative societies so-called, and are not members of the Co-operative Union. They do not officially bear the name of co-operative societies, but only that of supply societies. Nevertheless, they preform a useful service in meeting the needs of an important class of consumers and helping them to live more cheaply than they otherwise could.

The same must be said of societics which distribute some part of their profits to their shareholders, but not the whole of them. However small this part may be it is sufficient to do away both legally and morally with the co-operative character of the societies. The only exception which can be allowed to this rule is that of the payment of a fixed rate of interest, which cannot be counted a part of the profits as it is, on the contrary, an essential part of the cost of production.

3 There are many such associations in the United States but they are not considered co-operative except by people quite ignorant of co-operative principles. They have usually been short-lived but liave often succeeded in collecting millions of dollars from foolish investors before they fail. Some of the most barefaced of these schemes even masquerade as Rochdale co-operative societies. In addition to 
(2) Those which, while they divide profits in proportion to purchases, have classes of members, i. e., a limited number of shareholders, who keep the complete control of the society in their own hands, and associate members, who take no part in the general meetings of the society. An example of this kind is the Society of Civil Servants of the State, the City of Paris, and the Department of the Seine. The society of persons employed by the City of Paris and Department of the Seine, founded in 1887, has 22,000 members, of whom $\%, 000$ are shareholder's and 15,000 merely

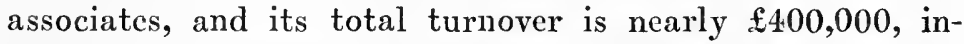
cluding the business amounting to $£ 80,000$ which it does with certain shops with which it has an agreement, and which undertake to give the members a discount, but this practice is also a departure from the principles of co-operation see above page 186). There are societies of a similar type in Italy.

The associates can become shareholders only when a shareholder gives way to them and sells his share. The shares are therefore much sought after and may be quoted above par in exactly the same way as the shares of a joint stock company.

Certainly their value will not rise as high as that of the similar societies in England, because the shareholders are on an equal footing with the associates with regard to dividends, but all the same they have a surplus value, owing to the fact that the shareholders alone have a claim on the reserve fund, which is constantly increasing, and also to the fact that the demand for shares is greater than the supply.

This large society, like those in London, stands apart from the others, and has always been considered even in legal procedure as a commercial firm.

vesting votes in capital rather than in men, these associations usually put all the controlling power into the hand of a few selected directors or trustees. 
(3) Those which allocate part of their profits to the members of the executive committee; the Supreme Court has decided in this sense on various occasions. Particularly in the case of the large society already mentioned which allowed the Executive Committee 12 per cent. of the profits and the Advisory Committec 3 per cent., a share which would have been exhorbitant, had it not been that as a matter of fact the members of committee wisely decided to limit themselves by their own action to a maximum of $\mathfrak{t} 48$.

It is not possible to lay down a hard and fast rule on the matter, for payment of committeemen may reasonably be allowed in certain cases, and may even have a good effect by weakening the temptation to reccive secret commissions or bribes. The payment can also be considered as salary for work actually done, and even if we consider it as a share of the profits, it does not seem to be more open to criticism than the share which is freely allowed to the employés, except in so far as it is liable to create unfortunate competition in the elections to the committees.

(4) Those which are not controlled democratically, that is to say those in which certain members have a dominating voice in the meetings by reason of the number of their shares or who are ex-officio members of the executive without being elected, as is the case in some consumers' societies which are under the patronage of employers and which are as a rule developments of benefit societies.

The four classes of socicty which we have deseribed are altogether unconstitutional and are not true co-operative societies although they bear the name, and generally the Federation does not accept them as members. But they are not numerous, while there are others, of which there are a great number, which, while constituted according to the orthodox principles, nevertheless have tendencies of an individualistic, bourgeois, or commercial character, in the 
sense that they are only concerned with obtaining individual advantages for their individual members.

The characteristics of these societies differ according to the country. In France, they can be recognized principally by their refusal to make any grants for educational or propagandist purposes or for reserve funds for developing the business, and by their unwillingness to join unions of societies. They say that they have no need of these things for themselves, and if others have such a need, that is their affair; and if they do vote the contribution which is necessary to maintain the union they do it with a very bad grace.

In England, on the other hand, there are practically no societies which refuse to fulfil their duties in these regards, but their individualistic tendency shows itself in the form of what is known as "divi-hunting." This has risen to such proportions that scarcely a number of the Co-operative News is without letters and reports of meetings devoted to this matter, which some people call a pest. ${ }^{4}$ However, these protests are not without effect, for it is recorded that during the last 15 years there has been a slight decrease in the average rate of dividend. Nevertheless, there are still a number of societies which pay more than 20 per cent. In France, the consumers' societies of the miners of Anzin pay a dividend of 20 per cent., that of Saint-Remy-sur-Avre paid 13 to 15 per cent., for a long time, and that of Geneva has paid 13 per cent. for the last 20 years.

4 In the United States such societies, in addition to these characteristics, usually carry this distinction: they are noted for their timidity in times of social crises. Their members are so closely related to the profiteering classes in society that they refuse to espouse publicly the cause of the wage earners during a strike or lockout, they are ultra-patriotic during national crises, they are conservative politically. Even though they are not economically tied up with the exploiting classes, their cultural background is of this type. Between the members of such a society a real co-operative spirit often develops, but this spirit is too often so closely confined to the particular group, that the resulting clannishness, exclusiveness is far worse than the most highly developed class-consciousness among radicals. 
There are also a few socialist socicties in Belgium and France, particularly in the Department du Nord, which pay even higher dividends-thus the Roubaix Society pays 28 per cent., and the Vooruit, of Ghent, paid 38 per cent., before the war.

In the same way one can only call those societies whose sole object is to give their members a taste for practising thrift, individualistic societies; we have already remarked (page 20) that that was precisely the rôle which economists of the liberal party in politics assigned to co-operative societies in general. This was the idea which Schultze-Delitzch formed of credit co-operation and consumers' co-operation, and to which the Central Union which he founded has remained faithful, thus causing the schism of which we have already spoken (page 45). Such also was the view held by the French statesman, Leon Say. In a discussion on this subject at the Society for Political Economy in November, 1886, he defined co-operation, whether for distribution, building, credit, or other purposes, as savings banks brought to a pitch of perfection and using their funds through and for the benefit of the depositor. This was also the theory of a great economist, Walras, who at that period was conducting a campaign with Leon Say. Co-operation was for him the amassing by the worker of capital by means of savings.

Returning to this definition in a lecture on November 27 th, 1886, he added: "If the co-operation movement has an ethical effect, it is through the ethical value of thrift. If it makes for thrift, it does so by the capacity of thrift to create freedom." At the same time he did not seek to conceal from himself that "a number of people engaged in the co-operative movement will consider that this point of view is lacking in idealism; for them the object is not the creation of habits of thrift, it is the liberation of the working man." 


\section{$2 \% 2$ CONSUMERS' CO-OPERATIVE SOCIETIES}

However, the characteristics which we have just enumerated-class spirit, thirst for dividends and absorption in individual savings-are not sufficient reasons for disqualifying socicties of this kind and refusing to allow them the name of co-operative societies.

Such as they are they can do very useful work, and they may even be considered as a necessary phase in the development of the movement; they are the chrysalids of co-operation.

\section{(2) The Socialist Type}

We have already recognized that socialist co-operative societies generally get a larger measure of discipline and more sacrifices from their members than do the bourgeois societies. This is quite natural; in every department, and at all times, the fighting spirit and the spirit of solidarity go hand in hand, and those who are engaged in any struggle are more inclined to close their ranks and agree to sacrifices than those who merely pursue a more or less distant ideal; we can casily understand that those who are fighting for the red flag will probably be more ardent than those who follow a star-a star which in most cases is only visible to the few.

But as far as concerns their constitution and their working the socialist societies do not differ essentially from the bourgeois ones.

However, the following are some outstanding differences:*

(1) They give no interest on share capital, as a rule, but are obliged to give interest on borrowed capital, when they have to borrow.

(2) They are generally "class" associations, that is they

* Author's Note. As far as management is concerned they generally do away with the office of president, being satisfied with a secretary. They give (in theory, at least) more favourable treatment to their employés, not only in wages, but also in regard to participation in the administration. 
only admit workmen, or, at least, wage carners; there are some which only admit members of trade unions. And all the societies which belonged to the old group called la Bourse des Coopératives (Co-operative Exchange) only admit members who are adherents to the program of the soeialist party. This meant a subscription annually per member towards the party and "socialist propaganda." This attitude is intolerant, but logical; we can see that societies which place co-operation upon a footing of class warfare cannot without inconsistency open their ranks to members belonging to the very class against which they are fighting, and whose presence could only have the effect of weakening their cause. Even among the socialist co-operators there are many who condemn this view: "As for making it obligatory to belong to the socialist party, that is a different matter. We do not pose as adversaries of the party, but we believe that to accept this idea would be to throw a bone of contention among our societies, which could only result in the formation of two opposing parties among co-operative comrades." Thus one of the reporters expressed himself at the Socialist Congress of Monthermé, 1909.

(3) They are much more bent on the socialization of production, that is they only admit productive enterprises as appendages of consumers' societies, as mere workshops, and not as autonomous associations (see page 237). They even go so far as to demand nationalization of the land. The English co-operative societies, although not socialistic, passed a formal resolution to this effect at the recent Congress in Laneaster (1916), because of the conditions arising out of the war: "The Congress urges that as the Government has assumed control of industry it will also take over the control of land . . . with a view to promoting all its resources in the fundamental interests of the nation." 


\section{CONSUMERS' CO-OPERATIVE SOCIETIES}

(4) And as for the distribution of dividends, we must distinguish between theory and practice. In principle, they condemn all individual distribution of profits as tainted with capitalism and selfishness, and declare that these dividends should be dedicated wholly to works of general social utility, which we shall mention. ${ }^{5}$

But as a matter fact this ideal is realized only by a very small number of societies, perhaps only one, the "Fraternelle" of Saint-Claude, which is considered a perfect type of socialist co-operative society. An immense majority of these socialist societies distribute a large part of the surplus to the members, because they know well that if they did not make this concession to the selfishness of human nature they would lose a good many of their members, or at least they would get no new recruits. The typical co-operative socialist society, the "Vooruit" of Ghent, distributes enormous dividends, which exceed 30 per cent. However, this does not arouse the same criticism, as it is counter-balanced by large contributions to works of solidarity, as we shall indicate presently; and as far as the "Vooruit" is concerned the dividend is not distributed in money, but in dockets exchangeable for goods at the social shop, which means that it comes back to the society, and has not to the same degree an individualistic character. But they do homage, nevertheless, to the principle, by reducing the individual distribution to the minimum necessary to retain their members-particularly to keep the housewives-generally by limiting the bonus to 5 per cent. on purchases, and dedicating the surplus to works of collective utility.

The methods of employing their money, which are characteristic of the socialist co-operative societies, are various :-

F In the United States there are very, very few societies which follow all these practices. A few of the most radical Jewish, Finnish, and Italian societies are of this kind. 
(a) For the common profit of members, in the form of sick benefit fund, for unemployment, for old age pensions, loans, medical or legal advice, and any other object designated as works of solidarity. It was the Belgian societics which first set this example. Thanks to the many advantages which they offer to workmen they can always attract and retain a large number of adherents, more effectively than by the distribution of dividends in money (we know, too, that of ten part of the dividend is distributed not in money, but in goods).* The large French co-operative societies of the Département du Nord have followed their examples.

The organization of a free medical service is an interest-

* Author's Note. The Vooruit of Ghent, for example, takes from the surplus enough to supply the following serviccs:-

(1) Free bread (six loaves weekly) in case of illness, for six weeks, always on the condition that the member has regularly bought an equal quantity of bread; if not, he has only the right to an amount equal to that which he was in the habit of buying. This acts as a stimulus to loyalty.

(2) Free medical advice and medicines in case of illness during six months, on condition that the medicines are procured from the Vooruit pharmacies.

(3) Superannuation pension, under fairly numerous conditions: age, 60 years, a membership of at least 20 years, the exclusive purchase

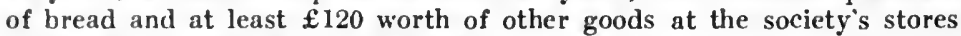
during the course of these 20 years;

(4) Gift of 10 loaves, with cakes and groceries at every birth;

(5) An indemnity of $7 \mathrm{~s}$. $6 \mathrm{~d}$. in case of death, given to the nearest relative;

(6) The savings bank, giving 4 per cent. on the deposits;

(7) Technical instruction, subsidies to musical societies, to theatres. to gymnasiums, travelling, \&c.

These works, altogether, represented before the war from $£ 1,200$ to $£ 1,600$ per year, taken from the actual profits, and are kept as regards the book-keeping quite distinct from "returns" made to the members which, in the case of bread, are merely the result of an increase in prices.

The Unione of Lille has organized more or less the same services:

(1) Free bread to indigent families;

(2) Free loans;

(3) Co-operative propaganda;

(4) Subsidy to the Socialist Federation.

Very frequently, too, sums dedicated to these works are deducted from receipts of fêtes and concerts, fines, \&c., which permits the reduction to a minimum of the sum taken from the dividends. 


\section{CONSUMERS' CO-OPERATIVE SOCIETIES}

ing feature of socialist co-operation, and one which impresses English delegates when they visit us. Generally it is only those of at least a year's membership, and who have made the minimum purchases at the store- $£ 12$ to $£ 16$ for a household; $£ 74$ s. to $£ 8$ for a single woman-who have the right to this medical service.

From 3s. 4d. to $4 \mathrm{~s}$. $2 \mathrm{~d}$. per family was estimated as the cost of this service from the society, assuming, of course, the employment of doctors who have accepted the tariff fixed by the society and also that the members will have recourse more often to a consultation in the dispensary rather than expect a visit from the doctor in their homes.

(b) For the development of the co-operative movement itself, by propaganda and education: we need add nothing on this point, which already constituted, as we know, an essential article in the Rochdale program (see page 92).

(c) For the benefit of the working class in general, for helping it in the class war, either by monetary aid in the case of strikes, or by subsidies in electioneering campaigns. This is what the Belgian co-operative societies and the French ones of the Dêpartement du Nord put into practice. But thereby these societies avowedly enter into the realm of politics, and by doing so they necessarily exclude from their ranks all those who do not share their opinions. This method of employing their funds has aroused the most animated polemics between socialists and neutrals-we shall return to it.

(d) Lastly, a very interesting method, but which is seldom adopted, is the constitution of a common indivisible, inalienable fund, one which, even in case of the dissolution of the society, cannot be returned to the members, but will be given to the parish, or to some work of general public utility. Here is a resurrection of mortmain, in a lay form. This interesting form of disposing of a reserve fund is 
practised in the society La Fraternelle of Saint-Claude," but it is improbable that it will become general, as it demands a little too much disinterestedness. And who would profit?-future generations, the proletarian of the future, who probably will be in much better circumstances than the workman of today, and much better able to help himself ! We know that Buchez started the first productive association (in 1834) on this principle, and had to abandon it. ${ }^{6}$

\section{(3) The True Co-operative Type}

Most of the societies in every country can be classified under one or the other of the two preceding headings. But neither one nor the other answers to the idea which we have of true co-operation, such as we have drawn in this book. Indeed, we may say that both the one and the other are only deviations from the form and type conceived by the pioneers of Rochdale. This is why we should try to restore it with the modifications which social evolution has rendered necessary; and such is the task undertaken in France, notably for the last 30 years, by those who have often been called neo-co-operators, but who are content with the more modest name of the School of Nîmes, the

"Author's Note. It was in 1896 that the society "La Fraternelle," of Saint-Claude passed (not without difficulty) an amendment to its rules, according to which all the profits should henceforth be put into the social fund, i.e., 50 per cent. to an inalienable reserve fund, destined ultimately to organize production; 30 per cent. to a pension fund; 20 per cent. to a provident and mutual aid fund. In the event of the dissolution of the society the funds would return to the commune of Saint-Claude, in spite of any possible opposition of the majority. (As to the legality of this clause, see above, page 210).

6 The use of surplus-savings for some general social purpose is not common in the United States except among the morc radical societies. Educational work and propaganda are common to the majority of societies. Less common, but becoming more and more frequent, is aid given to striking workers or the unemployed. There are many instances of help given to the sick, of rellef scnt to Russian famine sufferers, of funds donated to the amnesty campaign in behalf of the political prisoners. 


\section{CONSUMERS' CO-OPERATIVE SOCIETIES}

origin of which we have already explained (page 42). They do not profess to preach a new gospel, but seek to bring that of the Pioncers up to date, rather like the Reformers of the 16th Century, who called themselves the true successors of the apostles. The results obtained have not been great; however, in France, and even elsewhere their work in the co-operation movement has been far from insignificant.

The program of the neo-co-operators resembles that of the socialist co-operators so much that they are generally included in the same excommunication by the economic liberal school.

With no less fervour than the socialist co-operators they fought unceasingly against the individualist and commercial conception of co-operation, and even more than these, they strove to give it an ideal. Recently, at the Scottish Summer School, Mr. James Deans said: "What is most urgently needed at present is to awaken in present-day co-operators the enthusiasm and the idealism of the period of the Pioneers." This is what is being attempted at Nîmes. ${ }^{7}$ And even the most essential item in the socialist program, namely, the socialization of the means of production, may be accepted by co-operation; how can it do otherwise when it aims at placing successively commercial enterprises, manufacturing industry, and eventually even agricultural production in the hands of associated consumers? True, cooperators want to realize this socialization to the profit of

7 The campaign carried on for several years past by The Co-operative League has been aimed not merely at dissemination of facts about the organization and administration of co-operative enterprises and the standardization of co-operative laws and customs; it has realized that the movement is certain to develop anyway and that it will in some measure create the proper technique for its own development as it progresses, and therefore The League has put its greatest emphasis upon the propagation of these ultimate ideals which express the spiritual purpose of the Consumers' Co-operative Movement. Gradually there is thus being erected a tradition that demands educational activity on the part of all societies which consider themselves a part of the movement in the $U$. S. 
all consumers, that is, of every one, while the socialists only desire to realize it to the profit of the working class, because this is the only class they regard as being exploited.

It is also true that co-operators do not aim at confiscating wealth already existing and appropriated, but at creating new wealth which they will keep for themselves. But what does it matter? If their scheme is realized the old capital engaged in commerce or industry will become useless, as it will be without value since it cannot be utilized. This would therefore mean expropriation without indemnity. And, moreover, it would not be expropriation by force of a revolution or by legal coercion, but purely economic expropriation, similar to what goes on every day by the play of open competition, by new inventions, or by the opening of new markets.

It must, however, be admitted that this program is lacking in one respect, which is of no small importance-it is with respect to land. We say that we need not socialize capital already existing, because co-operation will create new funds-good: although socialists declare that this is an undertaking beyond the power of workmen's savings (see page 27). But as far as land is concerned it is obvious that we cannot say that co-operation need not socialize land already owned by others, because it can create more land. We can create new capital indefinitely, but we cannot create new land. If a co-operative society, therefore, wishes to gain possession of land it must purcliase it, and this seems an almost impracticable undertaking.

And that is why agrarian socialists, and even agriculturists who are not socialists, like Henry George and Walras, do not hold co-operation in much esteem. They say that co-operation is unable to solve the agrarian question, which, in their opinion, is the chief, even the only question, all the others being governed by it. Walras says: "The co- 
operative solution is to say to the workers, leave the rich alone and make your own fortunes." Their answer is, "I want justice, and not riches. I claim the heritage of my fathers." And Henry George says that co-operation is not only unable to abolish the great social evil, which is ground rent, but that in improving the condition of the workers it will have the result, like all material progress, of increasing rents.

To this objection the socialist co-operators answer, as we have seen, by accepting and even claiming the nationalization of the land and minerals (see page 273 ).

Co-operators content themselves with the hope of seeing landed property transformed gradually by the development of agricultural co-operative societies, associations which are destined more and more to be subordinated to the control of consumers' societies (see page 241).

From the practical and present point of view the following are the aims which are the same on both sides:-

(a) Co-operative education, according to the Rochdale doctrine, in order to prepare new generations of co-operators, without which the realization of the large co-operative society will be impossible; this is to be effected by all the means we have already indicated, conferences, classes, papers, publications \&c. (see above, page 94).

(b) The creation of Co-operative Unions, Purchasing Federations, International Co-operative Alliances, with the object of maintaining solidarity among all the societiesabove all to the advantage of the weaker ones-and thereby to give an irresistible strength to the co-operative movement in every country and in the whole world.

(c) Formation of a reserve and development fund, with the principal object of the organization of production, which is the ultimate aim of consumers' co-operation, whether this production is executed by consumers' societies directly by their own means, or whether it is attained by self-govern- 
ing associations for production, controlled by consumers' societies.

But their differences are:-

(1) Co-operators do not at all express the intention of suppressing the individual distribution of dividends, recollecting Pascal's saying, "that he who wants to make an angel, makes a beast (qui-veut faire l'ange, fait la bête) knowing also that it means not only the arrest, but the death of the co-operative movement in every country. They believe that the fact of not allocating profits to the capital constitutes a sufficient revolution. They rely solely on the progress of co-operative education to induce the members to consent to an increasing reduction in their dividends. For the rest, we have already seen that the individual distribution of dividends is just as widely practised among socialist co-operators, with few exceptions, as by the individualist or neutral co-operative societies. Professor Hall, one of the leaders of the English co-operative movement, said recently that "it has been ascertained that the number of members increases most quickly in places where the dividend is lowest." But in spite of this assertion, perhaps somewhat optimistic, he does not by any means propose to suppress the individual participation, but merely to reduce it by one-half.

Nevertheless, just like the socialists, they reserve a portion, the largest portion possible, for common works of utility. These works are in part the same as those advocated by socialists-education, contributions to national federations and the International Alliance, and, above all, to organizations for production-but the divergence of opinion arises over such works of solidarity as sickness, unemployment and strike funds, superannuation, \&c.

We should remark that associations specially created for this purpose already exist, and that it is not a good plan to ask the consumers' society to adapt itself to every object: 


\section{CONSUMERS' CO-OPERATIVE SOCIETIES}

institutions, like all enterprises, should conform to the law of division of labour.

'That members of consumers' societies should be advised to employ part of their dividends to pay their contributions to mutual aid societies, to unemployment funds, or to trade unions, is well and good. They would thus learn by liberty the practice of solidarity; but they will never learn this if it is the society which, without consulting them, pays their contributions for them.

And cven from the trade union's point of view, it is not a method to be encouraged, because, in thus accustoming them to live like parasites upon the body of consumers' societies, they are being prepared for the lot of parasites, they are being made degenerate. It has been remarked that the workmen's trade unions in the North of France, a large industrial region, show little activity, and scarcely even any vitality ; it is because they are kept by the co-operative societies.

(2) The co-operative societies are open to all. They exclude no one on account of his social position, his political or religious opinions: they do not impose any condition for admission, such as being a member of a trade union, or of belonging to the socialist party, or the Catholic Church, \&c. It is not merely in a spirit of tolerance that they do this, but because the logic of their program demands it: because it is in fact the emancipation of the consumer they aim at, the only condition they demand of their members is to be a consumer. In this they also show themselves faithful to the Rochdale program because it declares that there should be no "enquiry into the political or religious opinions of those who apply for membership"-_Fay, "Co-operation at Home and Abroad," page 282).

It is true that this attitude has brought upon the societies which adopt it the scornful epithet of "neutralist." They were themselves wrong in accepting or employing this 
qualification to distinguish them from others. It is incorrect and regrettable. Even before the late war, this word was disliked by all classes of belligerents. It seemed to justify the sareasm of those co-operators who glory in the fact of not being neutral, and to give these latter, by contrast, an imaginary virility. "Ncutral co-operation has no ideal, it does not raise the moral and intellectual tone of its members, and consequently cannot undertake any social rôle." (L'Humanité quoted and approved by the Catholic paper Sillon of December 10th, 1906).

But here we are not concerned with neutrality in the sense of powerlessness or of indifference in taking sides. It is a question, on the contrary, of a decision and of an energetic determination not to keep the benefits of co-operation for any one class or party, but to make them accessible to all, as generously as is the light of the sun or water from the spring. We do not overlook the strength which a strong and simple idea gives to any group of men, above all when it forms part of their corporate or class interests. But if they must carry any particular colours in their caps co-operators find themselves forced into separate organizations, and this can only increase the state of disunion of the French movement which is already deplorable.

Observation of the facts clearly shows that co-operation is respected and attracts the citizens of the towns only in those countries where its political neutrality is recognized. The only countries where co-operation has taken on, a political colour are France and Belgium; ${ }^{8}$ the example of the former, which is almost at the bottom of the co-operative class, is enough to warn us of the danger of this policy. Even in Belgium, the Vooruit of Ghent, or the Maison du Peuple, in spite of their well-earned reputation, are far from representing as large a proportion of the population as less

${ }_{8}$ The Staff of the Co-operative Reference Library, Dublin, states that Italy may now be added to the number of countries in which coopcration is distinctly political. 


\section{CONSUMERS' CO-OPERATIVE SOCIE'TIES}

markedly political or neutral societies such as Basle, Leeds, or Breslau. M. Hans Müller remarked in his pamphlet "La Théorie de la Lutte des Classes" (the Theory of Class War) that the Bâle Co-operative Society had 30,000 members out of a population of 125,000 inhabitants, i. e., 24 per cent. The Brussels society, called "Maison du Peuple," had 20,000 members out of a population of 650,000 , i. e. only 3 per cent. If we multiply the number of co-operators by four, to embrace families, these percentages would be respectively 96 and 12 .

The principle of neutrality is moreover, adopted not in England only, but in almost every other country. At the Swiss Co-operative Congress at Bâle, in 1900, in response to a motion brought forward by some socialist-cooperators, it was passed by a majority of 60 to 16 , that "co-operative societies must keep neutral in religion and politics." And German co-operative societies of the Hamburg Federation-a large number of whose members belong to the social democratic party-have repeatedly proclaimed the principle of neutrality in the co-operative societies, while upholding the class war among the trade unions. The International Co-operative Alliance has constantly affirmed this principle at its congresses, in spite of the efforts of the extreme Left (particularly at the Cremona Congress in 1907) to make them retract this declaration.

In the opposite sense, M. Vandervelde in his book "In Coopération nutre et la Coopération Socialiste" (1913), is very strongly adverse to neutrality. But his arguments appear to be based on conditions peculiar to Belgium.

It is further to be remarked that the very socialists who are loudest in their attacks on political and religious neutrality in co-operative societies are the first to recognize it in their trade unions!

(3) A further difference, though it is implied in the preceding one, is that co-operative societies refuse to take any 
part in political matters in distinction from the socialist co-operative societies of Belgium or the North of France, which take an active part in election campaigns and provide money for them. In point of fact, as far as socialist cooperation is concerned, it is only Belgium co-operative societies and the French ones of the Nord which have taken up politics, properly so-called. And even the latter do not go as far as the Belgian societies, which allocate moneys to electioneering funds in order to get such or such a deputy elected-they content themselves with making contributions to the funds of the socialist party, sometimes called the Guesdist party.

The question has frequently arisen in Britain and has been the cause of acute controversy, though there are no societies there which fly the socialist flag.* The question arose at the Paisley Congress in 1905 in a modest form. The question was whether the co-operative movement should take steps to secure the election of a representative in Parliament apart from all connection with the Labour Party, or any other political body. The proposal was rejected at two successive congresses by overwhelming majorities, and out of 1,400 societies only six were in favour of it. British co-operators were alarmed at the idea of politics bringing discord into their societies and breaking up their fine movement. But the war has completely changed their opinion. It has made co-operators feel that if they had had a place in the Government they would have been able to avoid the privations and sufferings which the war caused. The result of this change of opinion was that at the Swansea Congress (1917) parliamentary representation of co-operators was proposed and passed by a large majority, in spite of the opposition of some old co-operators, disdainfully

* Author's Note. See the booklet by Messrs. Alfassa and Barrault, Cooperation et Socialisme, which gives the opinions of the prineipal English co-operators and trade unionists on this question. 


\section{CONSUMERS' CO-OPERATIVE SOCIETIES}

called "the Old Guard." 9 In France we are more sceptical as to the importance of political action, and we have more confidence in that which is solely economic.

An additional difficulty in the way of co-operative societies going into politics is that they must conciliate the traders of the district in the interest of their candidate. That is why the big societies of the province of Nord confine their business to bread and coal. Finally, all the money spent on elections means so much less for the real work of co-operation, namely the formation of capital for production.

It does not follow that co-operation societies have not the right and even the duty of agitating to obtain laws favourable to their development, or of fighting laws which are harmful to them. The British societies have their Joint Parliamentary Committee which undertakes this work. The work of this committee is in no way incompatible with political neutrality, and would not become so even if it were formed of Members of Parliament provided they were chosen not for their political views, but because of their sympathy with co-operation. In the old French Union Cooperative (see page 155) it was the rule not only that the Union took no part in politics, but even that the committee mem-

9 Professor Hall, of the Co-operative Union, states that at this Congress held at Swansea in 1917 it was decided that steps should be taken "to secure direct representation in Parliament as the only way of effectively voicing its demands and safeguarding its intersets." A year later a "Co-operative Parliamentary Representative Committee" of the Co-operative Union was set up by a resolution of the Liverpool Congress. This Committee is now called "the Co-operative Party."

In 1920 the proposal was made that a Labour and Co-operative Political Alliance be formed. When the matter came to a vote at the Cooperative Congress in 1921 the proposal was defeated by only four votes.

In 1921 the Government introduced a bill which would place a taxation upon the surplus of co-operative societies just as though that surplus were profits. The co-operators rallied their forces and the bill was defeated by two votes:-the first defeat for the Government of Lloyd George, but a defeat by so narrow a margin that the party in power refused to consider it a defeat and did not resign. 
bers should abstain individually from polities: none of them was ever a candidate, cither in parliamentary or municipal elections. In the new Co-operative Federation, several comnittee members take an active part in political life and some were candidates at the 1919 elections. But as a whole the Federation holds itself aloof from party politics, and even from the Labour Party.

It does not follow that we do not recognize the importance of political action in social progress nor even that the coming of the time which we have long called the Co-operative Commonwealth (la République Coopérative) does not necessarily imply the realization of complete democratic government in state and city. But we think that political action should be the result of the free initiative of individuals or bodies wholly distinct from co-operative societies.*

*Author's Note. See our article in the "People's Year Book" for 1921 on the relation between co-operation and politics in France. 
की 



\section{DATE DUE}

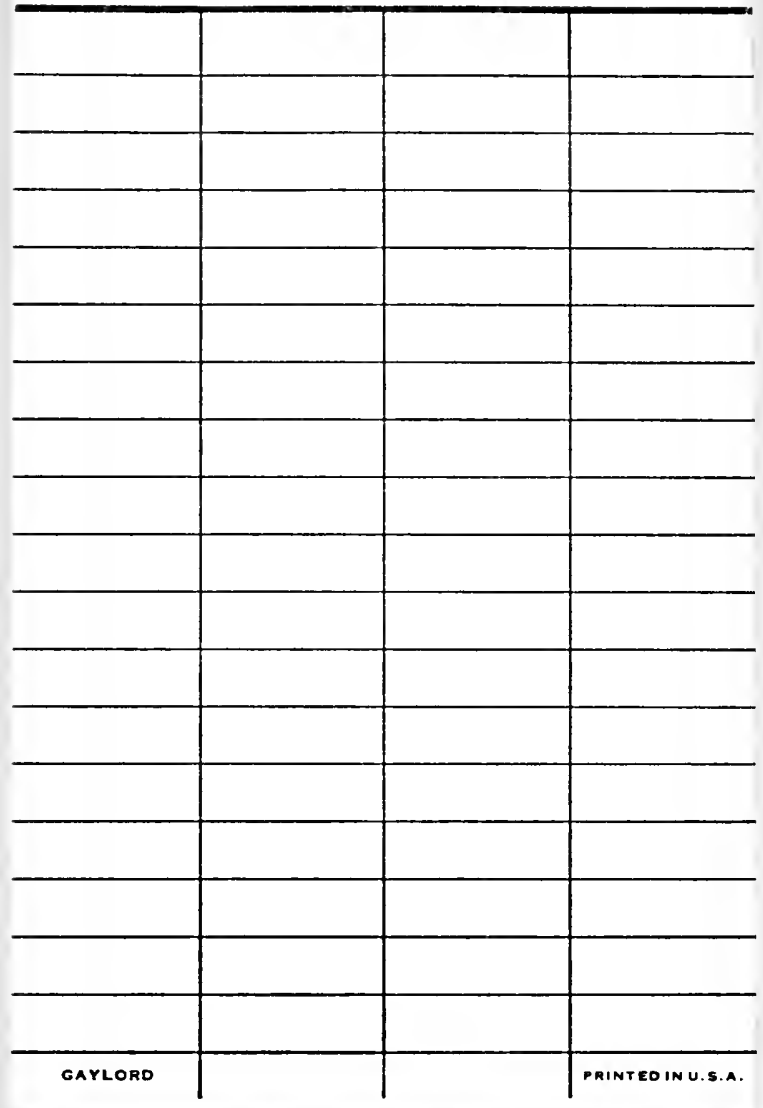


AA 0000305656

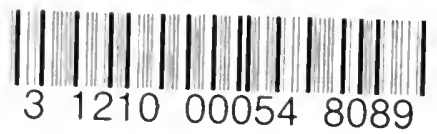

kP

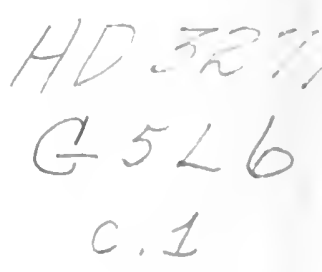




\section{-}

